\author{
UNIVERSIDADE DE SÃO PAULO \\ FACULDADE DE FILOSOFIA LETRAS E CIÊNCIAS HUMANAS \\ DEPARTAMENTO DE GEOGRAFIA \\ PROGRAMA DE PÓS-GRADUAÇÃO EM GEOGRAFIA HUMANA \\ DANIEL NUNES LEAL
}

\title{
Transformações da fronteira na Calha Norte paraense
}

(Versão corrigida)

São Paulo

2018 


\author{
UNIVERSIDADE DE SÃO PAULO \\ FACULDADE DE FILOSOFIA LETRAS E CIÊNCIAS HUMANAS \\ DEPARTAMENTO DE GEOGRAFIA \\ PROGRAMA DE PÓS-GRADUAÇÃO EM GEOGRAFIA HUMANA
}

DANIEL NUNES LEAL

\title{
Transformações da fronteira na Calha Norte paraense
}

(Versão corrigida)

Dissertação apresentada ao Programa de Pós-graduação em Geografia Humana da Faculdade de Filosofia, Letras e Ciências Humanas da Universidade de São Paulo para obtenção do título de Mestre em Geografia, sob orientação do Prof. Dr. Carlos de Almeida Toledo.

São Paulo 
Autorizo a reproduçīo e divulgaçĩo total ou parcial deste trabalho, por qualquer meio comencional ou eletrònico, para fins de estudo e pesquisa, desde que citada a fonte.

Catalogaçīo na Publicaçĩo

Serviço de Biblioteca e Documentaçaio

Faculdade de Filosofia, Letras e Ciências Humateıs da Universidade de Sáo Paulo

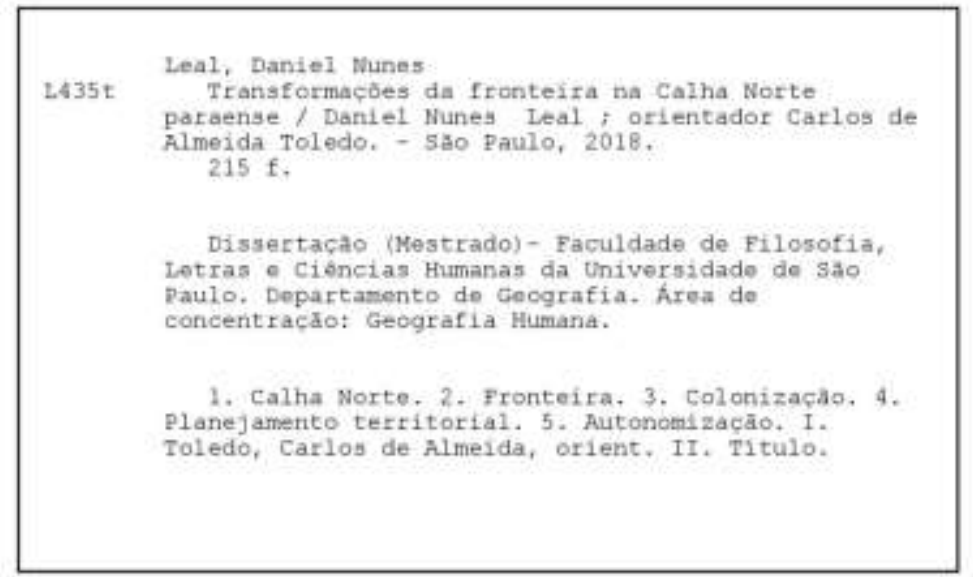




\section{TERMO DE CIÊNCIA E CONCORDÂNCIA DO ORIENTADOR (A)}

Nome do (a) aluno (a): Daniel Nunes Leal

Data da defesa: $15 / 02 / 2019$

Nome do Prof. (a) orientador (a): Carlos de Almeida Toledo

Nos termos da legislação vigente, declaro ESTAR CIENTE do conteúdo deste EXEMPLAR CORRIGIDO elaborado em atenção às sugestões dos membros da comissão Julgadora na sessão de defesa do trabalho, manifestando-me plenamente favorável ao seu encaminhamento e publicação no Portal Digital de Teses da USP.

São Paulo, 12/04/2019

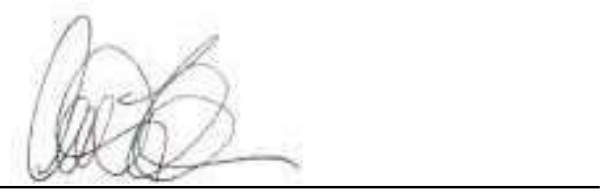

Assinatura do (a) orientador (a) 


\section{AGRADECIMENTOS}

Junto de tanto sufoco com a escrita, escrever os agradecimentos quando ainda estou com a cabeça fervilhando de ideias - e ansioso com o recrudescimento da repressão que está por vir pode acabar me tirando a concentração exigida para a tarefa, me fazendo cair no lugar-comum. Com isso, começo pedindo desculpas àqueles que esqueci citar. Nesses mais de três anos de mestrado, muita coisa aconteceu, conheci muita gente e delas me aproximei; de outras pessoas, me distanciei, tantas vezes porque as obrigações com a pesquisa e a vida em São Paulo foram mais fortes. Confesso, também, que há uma resistência do autor com o resgate de memórias.

Meus pais têm que encabeçar a lista: foram pacientes no tempo que tive de voltar a morar com eles e com a minha não submissão (temporária) à carteira assinada; e atenciosos, em meio às minhas desconfianças com o mestrado.

Agradeço ao Carlão: só depois da camaradagem, a orientação. Foi quem acolheu a pesquisa num momento difícil, em que eu sequer sabia que tema pesquisaria. E sempre chamando a atenção para partir do empírico, inculcando um sem-número de caminhos de investigação.

A Sandra e o Cássio foram muito dedicados na leitura de meu exame de qualificação, e por isso os agradeço. Deram valiosas sugestões, e espero que nosso diálogo esteja apenas começando. Ainda, a profa. Rita foi muito prestativa ao me colocar em contato com professores da UFPA.

Boa parte das reflexões desse texto é devido ao que aprendi estudando em conjunto às sextas-feiras no Labur com a crítica do valor-dissociação, pegando o bonde andando e quebrando a cabeça. O grupo d' $O$ capital das quintas, do Anselmo, foi indispensável na minha formação, e aos sábados também conversei com o Yuri e o Beto enquanto, de novo, lia com eles a obra tardia do velho barbudo.

Agora, peguemos o avião e o barco. Em Belém, sou muito grato ao Thomaz e ao Diego, que me receberam. Em Manaus, o agradecimento vai para o André, e em Santarém, à Lucybeth e ao Diego Amoedo, que me acolheram e me falaram bastante da área. Mas não busco retribuir a atenção deles apenas. A Geany talvez tenha sido a pessoa que mais me ajudou com os perrengues do campo: abrigou-me, introduziu-me a muito do que acontecia em Monte Alegre e apresentoume à sua família. 
Em Monte Alegre, Dona Graça e Seu Chico, além do Alexandre, pais e irmão de Geany, foram muito gentis comigo, me acomodando por semanas em seus lares com muita prosa boa. A Nea também foi bastante esmerada, e a Suzete dividiu comigo a experiência de quem era novo naquelas plagas. Dona Petinha foi um caso a parte: fiquei um tempo considerável em sua casa, ela foi muito amável comigo e nossa convivência foi bastante agradável. Na comunidade do Limão, Seu Imá e Dona Neninha deram o máximo para me acomodar. O Paulinho me hospedou com toda a atenção em sua casa na Serra Azul, e o pessoal do Incra tornou mais simples um deslocamento um tanto extenuante.

Voltando a São Paulo, as conversas e leituras em grupo de trabalhos ainda em construção me ensinaram a como ir levando a escrita, alterando-a diversas vezes. Aqui, Ceci, Pedro, Vivi, Caio, Olívia e Felipe falavam muitas coisas que me proporcionavam demoradas e inquietas meditações.

A companhia dos amigos foi extremamente reconfortante. Espero que eles tenham encarado como empolgação o quanto tenho sido repetitivo e com paciência minhas ausências e, às vezes, meu silêncio. Inclusive, dividi teto com alguns deles, e compartilhei bons momentos. Pedro Rittner e Will; Maísa, Virote, Carol, Raul e Jimi; Edu e Leo; Paulo, Mari e Mateus. Principalmente o Mateus teve que aguentar minha apreensão de fim de pesquisa; já o Will, foi muito generoso ao largar os compromissos de trabalho para me ajudar com os mapas. Em São Vicente, tem o del Vecchio, que foi quem mais ouviu sobre a pesquisa enquanto entornávamos uns canecos; e o Luciano, que além de tudo, foi fraternal ao me levar ao Rio e me acompanhar no IHGB e no Museu Nacional.

O presente trabalho foi realizado - e só assim foi realizado - com apoio da Coordenação de Aperfeiçoamento de Pessoal de Nível Superior - Brasil (CAPES) - Código de Financiamento 001. 


\section{RESUMO}

Nesta dissertação buscamos analisar transformações ocorridas nas áreas de fronteira que hoje integram a Calha Norte paraense (noroeste do Pará). Essas transformações são examinadas como parte da formação do território do Estado nacional no controle da população e na formação da estrutura fundiária brasileira. Tal processo se desdobra contraditoriamente, em particularidades regionais da produção de mercadorias e na subordinação do trabalho, que vão sendo mudadas com a formação dos mercados de terra, trabalho e capital e sua regulação pelo Estado. Num movimento histórico, a fronteira passa de lugar da posse da terra à reserva de superpopulação relativa num projeto nacional de acumulação, chegando à condição de lugar da preservação ambiental e da gestão de um lavrador confinado a sua terra. Os momentos discutidos expressam formas da acumulação capitalista em seus devidos contextos, nos quais a monetarização crescente das relações sociais impõe a venda de força de trabalho, mesmo que mantida a posse da terra. A acumulação, contudo, atinge um padrão crítico, em que a população lavradora cada vez menos subsiste de sua posse, e assim vai sendo administrada por programas governamentais de fomento em dinheiro.

Palavras-chave: Calha Norte; Fronteira; Colonização; Planejamento territorial; Autonomização. 


\section{ABSTRACT}

In this dissertation we aim to analyze transformations occurring in the frontier areas that today are part of the Calha Norte paraense (northwest of Pará). These transformations are analyzed as part of the formation of the territory of the national State in the control of the population and in the formation of the Brazilian land structure. This process unfolds contradictorily, in regional particularities in the production of commodities and in the subordination of labor, which are being changed with the formation of markets of land, labor and capital and their regulation by the State. In a historical movement, the frontier passes from place of the possession of the land to the reserve of relative superpopulation in a national project of accumulation, achieving at the condition of place of the environmental preservation and the management of a 'lavrador' confined to its land. The discussed moments express forms of capitalist accumulation in their contexts, in which the growing monetarization of social relations imposes the sale of labor power, even if possession of the land is maintained. Accumulation, however, reaches a critical pattern in which the population of 'lavradores' is less and less subsisting by his land, and therefore is being managed by government cash programs.

Key words: Calha Norte; Frontier; Colonization; Territorial planning; Autonomization. 


\section{LISTA DE SIGLAS E ABREVIAÇÕES}

ACEPRDIL - Associação Ecológica dos Produtores Rurais do Distrito do Limão APP - Área de Preservação Permanente

AASA - Associação dos Agricultores da Serra Azul

BASA - Banco da Amazônia S.A.

BB - Banco do Brasil

CAN - Colônia Agrícola Nacional

CANP - Colônia Agrícola Nacional do Pará

CAR - Cadastro Ambiental Rural

CCDRU - Certificado de Concessão de Direito Real de Uso

CCU - Certificado de Concessão de Uso

CEPLAC - Centro para o Desenvolvimento da Lavoura Cacaueira

CPT - Comissão Pastoral da Terra

DER - Departamento de Estradas de Rodagem

EMATER - Empresa de Assistência Técnica e Extensão Rural

FLONA - Floresta Nacional

FLOTA - Floresta Estadual

FNO - Fundo Constitucional de Financiamento do Norte

FUNDEFLOR - Fundo de Desenvolvimento Florestal do Pará

ICMBIO - Instituto Chico Mendes para a Conservação da Biodiversidade

IDEFLOR-BIO - Instituto de Desenvolvimento Florestal e da Biodiversidade do Estado do Pará

IMAZON - Instituto do Homem e Meio Ambiente da Amazônia

INCRA - Instituto Nacional de Colonização e Reforma Agrária

INDA - Instituto Nacional de Desenvolvimento Agrário

INIC - Instituto Nacional de Imigração e Colonização

IPEAN - Instituto de Pesquisas Econômicas e Agronômicas do Norte

ISA - Instituto Socioambiental

ITERPA - Instituto de Terras do Pará

LBA - Experimento de Grande Escala da Biosfera-Atmosfera da Amazônia

MDA - Ministério do Desenvolvimento Agrário 
MEB - Movimento de Educação de Base

MRN - Mineração Rio do Norte

PA - Projeto de Assentamento

PAE - Projeto Agroextrativista

PDS - Projeto de Desenvolvimento Sustentável

PF - Polícia Federal

PIC - Projeto Integrado de Colonização

PIN - Programa de Integração Nacional

PND - Plano Nacional de Desenvolvimento

POLAMAZÔNIA - Programa de Polos de Desenvolvimento da Amazônia

PROMASA - Associação dos Produtores da Matona Serra Azul

PRONAF - Programa Nacional de Fortalecimento da Agricultura Familiar

RB - Relação de Beneficiários

SNCR - Sistema Nacional de Cadastro Rural

SNUC - Sistema Nacional de Unidades de Conservação

SOCAMA - Sociedade Cooperativa Mista de Monte Alegre

SUDAM - Superintendência para o Desenvolvimento da Amazônia

SUDENE - Superintendência para o Desenvolvimento do Nordeste

SUPRA - Superintendência Nacional de Reforma Agrária

UAC - Unidade Avançada de Colonização

UC - Unidade de Conservação

UMF - Unidade de Manejo Florestal 


\section{LISTA DE FIGURAS}

Fig. 1. A rua na comunidade do Limão, com seus estabelecimentos comerciais ...................... 54

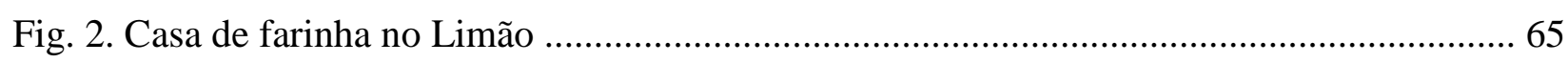

Fig. 3. Mapa mental de Avelino, localizando as comunidades que margeiam a PA-254 ......... 100

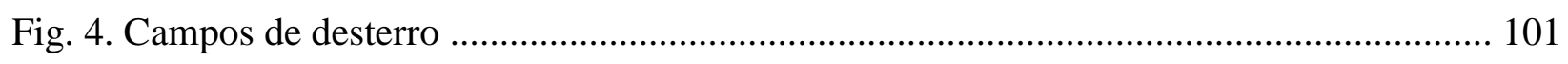

Fig. 5. O igarapé do Limão, praticamente seco ............................................................. 114

Fig. 6. Mapa mental de Koji Ueno, localizando os primeiros projetos japoneses de colonização

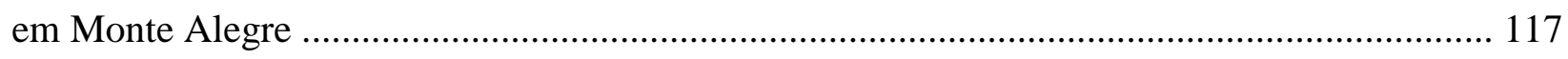

Fig. 7. Sede da Sociedade Cooperativa Agrícola Mista de Monte Alegre (Socama) ............... 120

Fig. 8. Vegetação "enjuquirada" na Serra do Itauajuri ........................................................ 157

Fig. 9. O núcleo de Matona ................................................................................................... 176

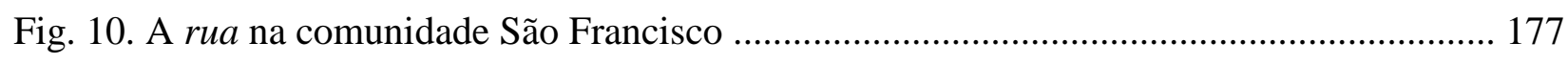

Fig. 11. Jovem família de lavradores no PDS Serra Azul .................................................. 184

Fig. 12. Vegetação devastada no PDS Serra Azul ........................................................... 187

Fig. 13. Mapa mental do PDS, construído pelos moradores com a madeireira RRX ............... 196 


\section{SUMÁRIO}

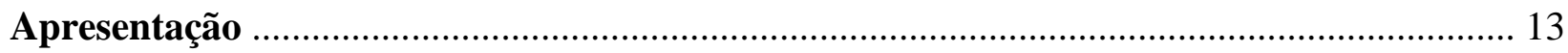

Composição dos capítulos ........................................................................................ 18

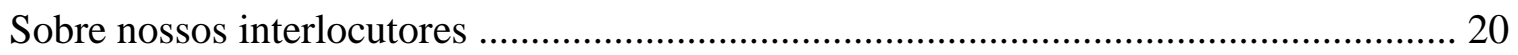

Capítulo 1. Formação da região e colonização ……………………………………………..... 22

1.1. Os primeiros projetos de colonização e a formação do trabalho livre no Brasil ....... 22

1.2. Dinâmicas regionais e o aviamento nos castanhais de Alenquer .............................. 34

1.3. Os projetos de colonização da primeira metade do século XX ……………………... 48

Capítulo 2. A comunidade do Limão, ou: determinação e espontaneidade ……………………... 53

2.1. Fundação e relações com o comércio ...................................................................... 55

2.2. Expansão territorial e aparência de espontaneidade ………………………………. 72

2.3. Relações de fronteira e o paradigma da "reprodução camponesa" .............................. 81

Capítulo 3. Do Limão ao Perímetro: mercado fundiário e de trabalho, Estado e fronteira .......... 93

3.1. Mercado de terras e avanço da fronteira ……………………………………........ 94

3.1.1. O "fechamento" da fronteira em perspectiva ............................................ 108

3.1.2. O patrimônio do Limão e a urbanização na fronteira ................................. 112

3.2. Monetarização e diversificação das relações de trabalho ......................................... 116

3.3. Autonomização do Estado, colonização e dissolução das dinâmicas regionais? .... 132

Capítulo 4. Conflitos e transformações recentes na fronteira da Calha Norte paraense ........... 148

4.1. Processos de expropriação e os limites da posse da "terra liberta" ..........................150

4.2. Novas políticas territoriais e a "estrutura produtiva camponesa" na fronteira ........ 167

4.3. Conflitos no PDS Serra Azul e o retorno à aparência de espontaneidade do lavrador

4.3.1. O Estado e as novas estratégias de controle do acesso a terra: o Programa

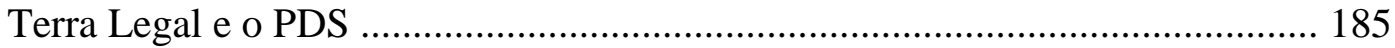

4.3.2. Como a fronteira pecuário-madeireira avança recentemente para a Calha Norte paraense?

4.4. Conservação, acumulação primitiva e crise ……………………………………..... 194

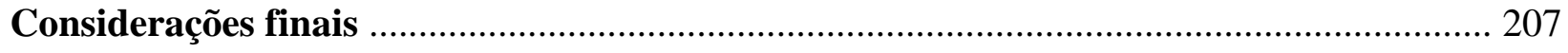

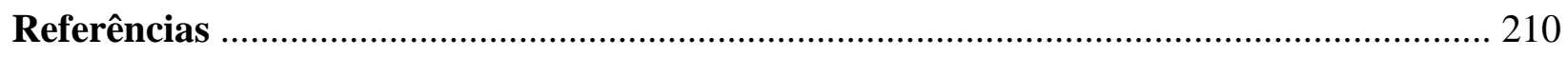




\section{APRESENTAÇÃO}

Até o que nós enfrenta aqui... aqui é uma fronteira agrícola, viu professor. E essa fronteira agrícola ela é disputada, entendeu. Nós estamos entre uma floresta nacional e uma estadual. Então, nós aqui, como que nós consegue produzir? É enfrentar. É só mesmo com a disputa de posição da gente, né. A gente tem que enfrentar com a disposição da gente [...] Então a Serra Azul é uma diversidade de gente, de vários município, né. Mas a gente enfrenta aqui, ainda não tá aqui paz e amor. Enfrenta dificuldade entendeu, aqui dentro. Nós tamo num lugar longe. Não tem nenhum financiamento, mas a gente tá aqui. Nós vive numa situação até de disputa, né, pelo espaço da terra, toda uma diversidade. Agora, a gente tá numa terra boa, né, que produz de tudo. Então a gente consegue produzir pra viver daqui, mas a gente ainda não conseguiu acessar o crédito do governo.

Esse depoimento de Paulinho, ex-líder de um assentamento rural de Monte Alegre, no noroeste do Pará, carrega aspectos comumente reputados à fronteira. Pela própria localização desse projeto, entre duas florestas públicas, a disputa se revela marco cotidiano da diversidade de lavradores ali instalados, a despeito de outros grupos. Já a disposição exigida na produção pode, em partes, ser confrontada com a reivindicação por planos estatais de assistência que mantenham aquelas famílias. As vicissitudes enfrentadas são identificadas com o isolamento, que dá margem a problematizações de como a terra é apropriada e que condições são entendidas como necessárias à produção.

Malgrado tais caracterizações, uma dissertação que discute transformações na fronteira em uma área como a Calha Norte paraense talvez cause estranheza. Isso porque, de modo geral, as pesquisas debruçadas sobre a fronteira amazônica se concentram mais nas ourelas das grandes estradas concebidas para a Amazônia entre as décadas de 1960 e 1980. Nesse caso, o enfoques é sobretudo nas faixas da Belém-Brasília, da Transamazônica e, mais recentemente, da Cuiabá-Santarém, apresentando casos impetuosos de violência. Perspectivas que são, por conseguinte, críticas a uma suposta harmonia na organização social da fronteira.

No que toca ao presente trabalho, realçamos semelhanças com as interpretações do planejamento do uso da terra e de controle do fluxo populacional constantes na bibliografia sobre o tema. O leitor notará que os processos que abordamos podem amiúde se desdobrar, digamos, mais lentamente ou em menor proporção. Mas não se trata de projetar uma escala de 
violência que autoriza ou não a investigação, e sim de mostrar aspectos de formação da base fundiária e de relações de trabalho, na reprodução capitalista, que são próprias da fronteira.

Em nossa pesquisa, a fronteira, numa conotação aproximada à de limite geográfico, corresponde aos limites do território de exercício da soberania estatal e ao movimento interno de expansão na constituição desse território. A dinâmica, por assim dizer, endógena revela um roteiro histórico e contraditório de formação e crise de condições determinadas de reprodução social. A fronteira assume contornos diversos, atinentes ao contexto debatido; ela exprime uma particularidade não como fato isolável, senão como momento da totalidade em processo. Significa dizer que no que hoje é a Calha Norte paraense, na margem esquerda do Baixo Amazonas, as relações de fronteira são alusivas à totalidade da imposição do território do Estado nacional, na mesma medida em que nela se reproduzem, como parte do processo, formas particulares de produção.

Para sermos rigorosos com essa particularidade num recorte caro à sua espacialidade, a região é um conceito inexorável ao argumento. Nessa altura, já é perceptível como a região não é um dado autoevidente ou uma abstração subjetiva do cientista, que levanta critérios de análise, inter-relaciona-os e chega a uma conclusão ${ }^{1}$. Nestes casos, a região seria um objeto autônomo em relação à sua constituição, ao passo que o método classificatório teria um status axiomático. Se a relação entre sociedade e meio é o que tradicionalmente subjaz ao conceito de região, é preciso frisar que é sua inserção na totalidade o que lhe confere particularidade.

A localização da área de pesquisa, sem esperar com isso qualquer qualificação cerrada, emerge do enfrentamento de fontes teóricas e do alcance da pesquisa empírica. Toda perspectiva esconde e representa uma faceta da realidade contraditória, mas a nenhuma delas pode ser imputada erros ou acertos. Assim considerando, consta no Mapa 1 a Calha Norte Paraense, que se estende, no eixo oeste-leste, do município de Oriximiná a Almeirim, além das estradas e rios elencados em nosso trabalho.

\footnotetext{
${ }^{1}$ Resumidamente, a primeira acepção é tributária da geografia de matriz francesa dominante até a década de 1960, na qual a região era um espaço a priori da descrição da relação homem-meio, através duma catalogação de fenômenos físicos e humanos; não obstante, a região como dado também poderia encetar a intervenção governamental, por meio de elaborações estatísticas das relações espaciais (cf. Lencioni, 2014, caps. 2 e 3). A última concepção, por sua vez, é aquela cara ao neokantismo de R. Hartshorne (1978), para quem à geografia caberia diferenciar áreas segundo elementos empiricamente significantes levantados pelo pesquisador. "Área", pois, é uma construção mental, devido ao "número literalmente infinito de elementos incomensuráveis" (ibid.: 39) que são racionalmente significados e "inter-relacionados" (ibid.: 22) na pesquisa. Sandra Lencioni (2014: 127), ao citar a dissertação de P.C.C. Gomes, concorda que a eleição do termo área, por Hartshorne, vincula-se ao descompromisso buscado por este com o sentido da região e suas noções agregadas. A autora especifica a arbitrariedade relativa ao conceito de região, o que leva Hartshorne a ressalvas e à preferência por "área", sobretudo quando trata de problemas de ordem teórico-metodológica. Sobre isso, Toledo e Boechat (2012: 451), objetam que a subjetividade do cientista refere-se a um processo social objetivo de diferenciação de áreas. Como se poderá observar, a região se inscreve como processo determinado pela totalidade objetiva.
} 


\section{Mapa 1 - Localização da Calha Norte paraense}

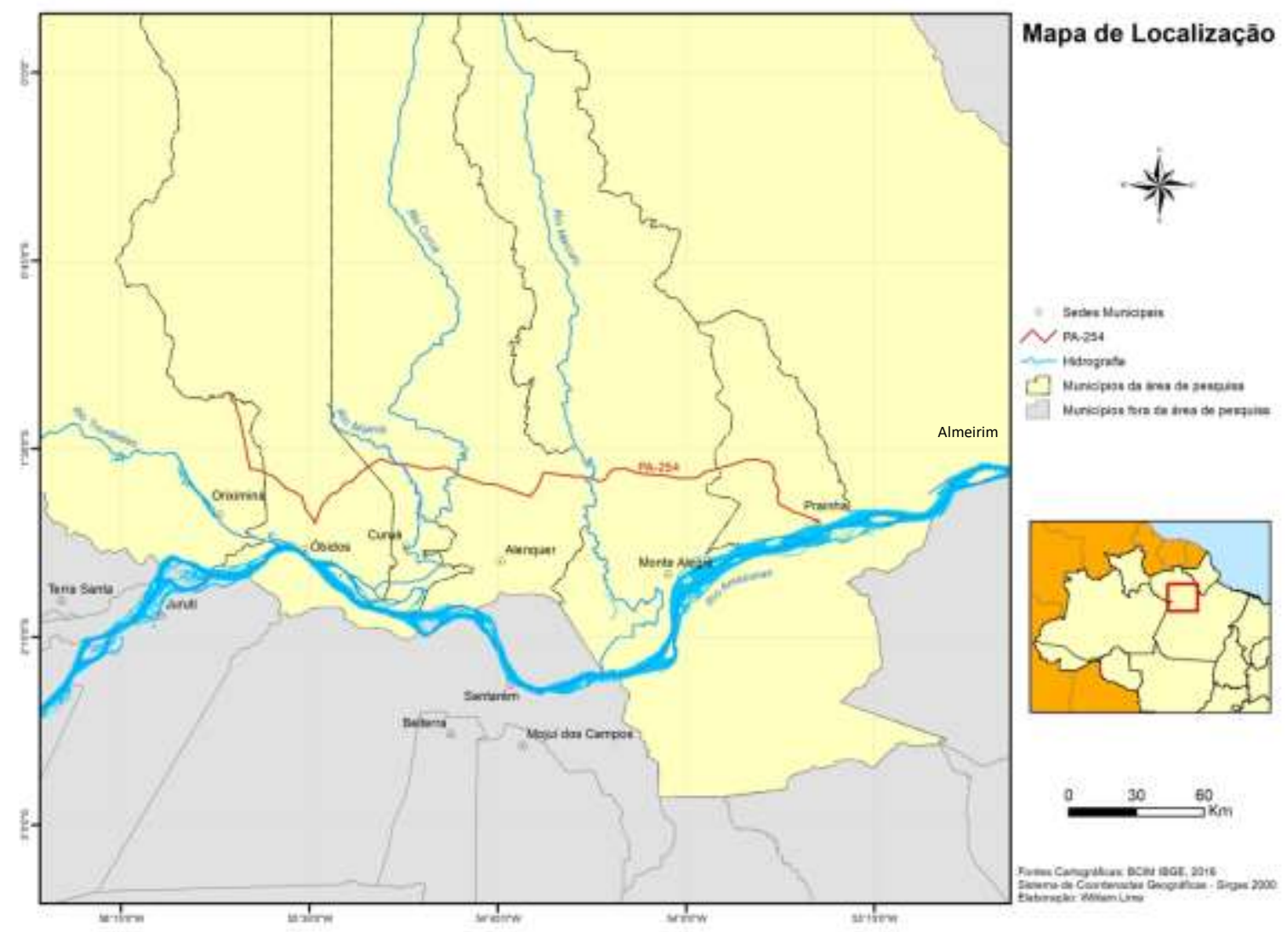

A pesquisa de campo foi realizada em comunidades de terra firme de Monte Alegre, a partir de entrevistas com moradores e da observação direta. De início, pretendíamos ouvir trajetórias de vida de varzeiros e lavradores de terra firme - especialmente idosos e líderes comunitários - para distinguir tópicos de impacto do planejamento territorial e do crédito rural na reprodução daqueles sujeitos naqueles locais. As grandes extensões percorridas, a dificuldade de acesso, a pertinência dos ciclos de cheia dos rios e a rede de contatos estabelecida foram delimitando, por assim dizer, nosso recorte espacial. Nesse aspecto, se antes pretendíamos visitar povoados de várzea, a expectativa fora deixada de lado. Em segundo lugar, sobretudo em nosso segundo trabalho de campo, a noção de fronteira foi ficando mais forte, com recorrentes referências ao termo quando estivemos no Projeto de Desenvolvimento Sustentável (PDS) Serra Azul. A partir da sugestão, quiçá não intencional, dos lavradores, o tema da investigação foi assumindo uma configuração própria, obviamente inseparável das leituras prévias. Daí segue o Mapa 2, com a localização das comunidades pesquisadas. 
Mapa 2 - Localização das comunidades pesquisadas

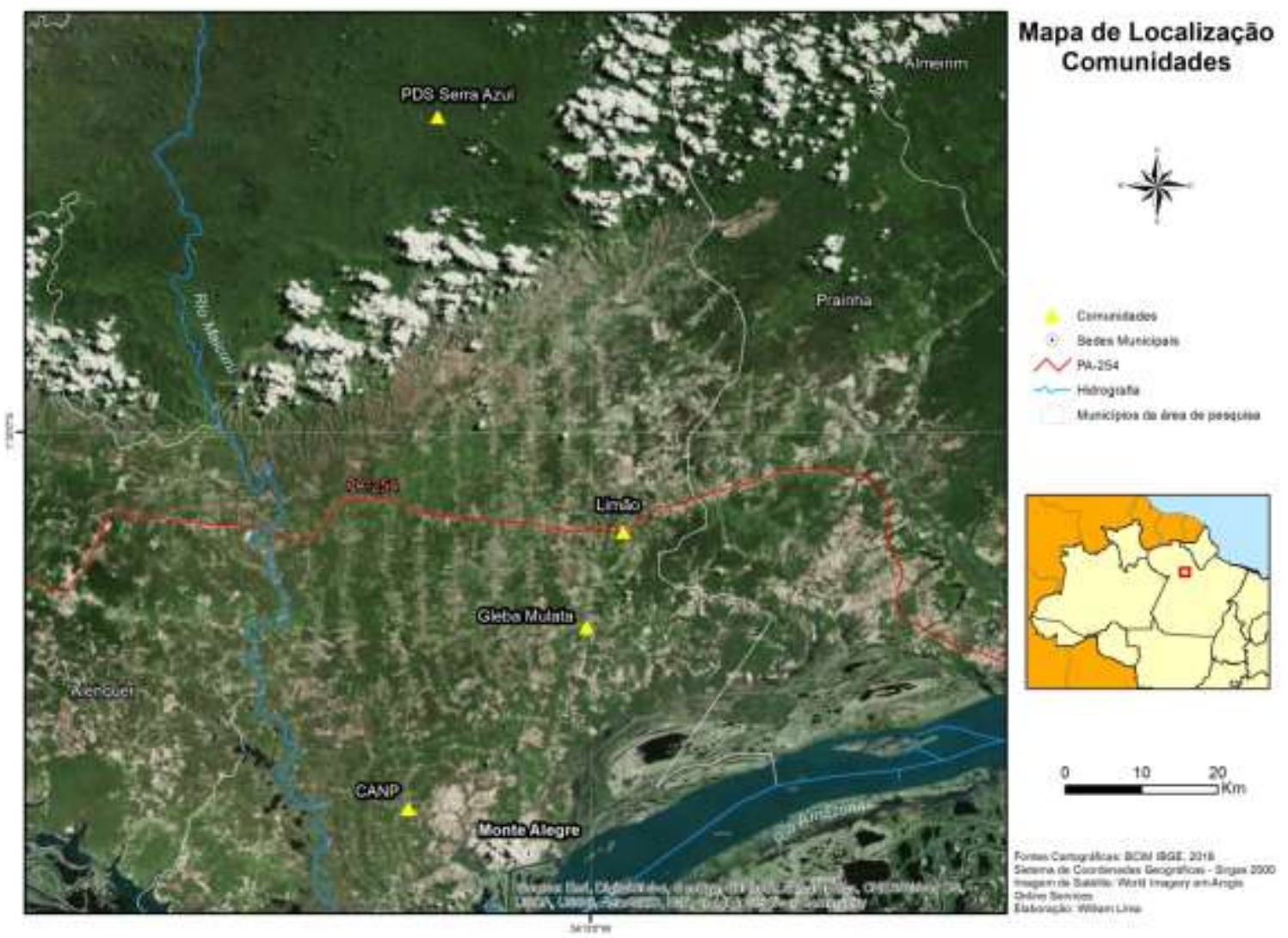

Os entrevistados personificam formas contraditórias das relações de fronteira, em relações particulares de trabalho e com a terra. Muitas vezes, essas narrativas funcionam como fio condutor do texto, e permitem a retomada constante da pergunta norteadora das transformações da fronteira e das relações de produção na área examinada. A intenção é que o empírico tanto desconstrua uma lógica dedutiva que poderia guiar a exposição quanto seja criticado como naturalização do processo social que preside o concreto. Na obra de Marx (2011, 1985, 1986, 1988), os sujeitos pensam e atuam como agentes da produção capitalista mesmo que não o saibam, permitindo a problematização de como esquemas que coagem à produção e circulação de mercadorias vão caracterizando a reprodução na fronteira.

$\mathrm{O}$ que imprime uma particularidade à fronteira investigada é sua própria formação histórica, dispensando um ponto de partida arbitrário na constituição do território de soberania do Estado nacional. No que viria a ser o Brasil, a formação territorial é marcada pelo que C. Prado Jr. (2000, "Introdução") chama de sentido da colonização: uma empresa de produção e exportação de produtos tropicais para o mercado metropolitano. Já com o fim do sistema colonial, tal sentido e a internalização das relações metropolitanas engendram particularidades regionais distintas. E a respeito disso, a obra de Francisco de Oliveira (2008: 145) privilegia 
um conceito de região fundamentado numa "especificidade da reprodução do capital", da acumulação e da estrutura e luta de classes. Historicamente falando,

Tais regiões assim se constituíram ligadas ao comércio internacional de mercadorias, sendo essa sua lei de reprodução no nível mais geral, mas, ao mesmo tempo et pour cause, mantendo ou criando formas de reprodução do valor bastante diferenciadas (ibid:: 146-7).

A produção extravertida de mercadorias tropicais estrutura particularidades regionais. Uma vez que produção é exploração de trabalho, podemos prosseguir no argumento retendo parte do que traçam Heidemann et. alli (2014) sobre a história do trabalho no Brasil; a saber:

o trabalho no Brasil não seria mais do que a consolidação da forma territorial inerente à própria territorialização do capital. Em síntese, a especificidade do trabalho no Brasil estaria ligada aos momentos particulares da territorialização da forma elementar do capital, a mercadoria: uma história da imposição do trabalho, sendo o próprio trabalho (abstrato) o elemento que nega especificidades ao processo, impondo às diferenças um caráter de particularidade da totalidade territorial (ibid.: 58).

No trecho, vemos como o capital se territorializa em particularidades regionais da produção de mercadorias, sendo o trabalho o que impõe às diferenças a totalidade territorial do Estado. Tal processo, momento da reprodução do capital, é também formulado como "territorialização do Estado" (ibid.: 60), e nessa medida, claro, a formação do território de soberania do Estado nacional é determinada pelo desenvolvimento do capital como forma da sociedade.

Resta abordar que a ocupação de "terras sem dono" que se realiza como fronteira refere-se à formação do trabalho e da estrutura fundiária brasileira, por meio da posse e da reprodução de relações de trabalho particulares. O processo não ocorre sobre um vazio, e assim pressupõe a violência da constituição da forma mercadoria, com expulsão, eliminação e submissão de populações autóctones - primeiramente, indígenas - a determinadas relações de produção $^{2}$. O movimento da fronteira é regulado pela territorialização do capital, do momento regional ao poder centralizado no Estado nacional na formação de seu território. Por isso, a exposição é assente num processo de modernização que atravessa do conflito aparente entre Estado e região para a formação de mercados de terra, trabalho e capital na fronteira. Existem transformações ocorridas nos meios de acesso a terra, nas relações de trabalho e dominação, na produção e na reprodução dos sujeitos que personificam as relações assinaladas. Já hoje, a

\footnotetext{
2 Daí “terras sem dono", "terras livres”, "terra liberta” ou termos congêneres virem entre aspas.
} 
incógnita em aberto toca na pertinência do sentido de continuidade na expansão da posse na fronteira. Aqui, adiantando, a violenta injunção do trabalho e da mercadoria vai dando lugar a uma gestão estatal que parece outorgar independência ao lavrador das áreas de fronteira. A questão é como e porque o processo social vai transformando certa conotação conferida à fronteira em outras formas de uso da terra, com intenções e modos de efetivação peculiares.

\section{Composição dos capítulos}

O leitor irá reparar que os capítulos desta dissertação iniciam com a retomada de discussões anteriores e a enumeração dos temas debatidos na sequência. Também é valido lembrar que as entrevistas e a pesquisa documental são bases para querelas teóricas, na contraposição de fontes diversas e na discussão com base no material empírico.

Posto isso, o capítulo de abertura apresenta aspectos da formação regional (Oliveira, 2008) e dos primeiros planos de colonização nas áreas de fronteira da margem esquerda do Baixo Amazonas, que representam a instituição do Estado no planejamento da formação de um mercado de trabalho nacional e na ocupação "produtiva" da terra. Como suporte, temos dois relatórios redigidos pelo engenheiro João de Palma Muniz, de onde elencamos tópicos para interpretação de relações atinentes ao contexto em questão, isto é, da metade do século XIX à aproximadamente a década de 1940. O primeiro dos escritos reconstitui historicamente projetos de imigração e colonização no Pará, que remetemos à formação do trabalho livre no Brasil e à meta de regular o acesso a terra pela colonização, discutindo com a reprodução do regime de colonato. O segundo escrito é fruto de uma expedição a castanhais em Alenquer, onde é ressaltado o conflito entre os interesses de grandes comerciantes locais e a perspectiva de regularização fundiária que o autor personifica, sendo o aviamento o esquema que particulariza as relações entre castanheiros e seus patrões. Ainda, temos a análise de projetos de colonização implantados entre as décadas de 1920 e 1940, mostrando uma organização progressivamente mais complexa do Estado na regulação de lotes já ocupados por migrantes nordestinos, além de intervenção da iniciativa privada na imigração de japoneses para a área.

O segundo capítulo se debruça sobre transformações vigentes entre as décadas de 1950 e 1970 numa comunidade de fronteira em Monte Alegre: o Limão. Vemos o abastecimento dos lavradores por um comerciante da cidade que encomenda a formação dos roçados, daí pondo a questão de como o empréstimo de dinheiro engendra a formação da área e, ao mesmo tempo, se prevalece o juízo de espontaneidade da produção, bem como a chance de jamais se pagar tal débito ao armazém. 
Já a aparência de espontaneidade na reprodução do lavrador se traduz no posseamento de terras e dilatação territorial da comunidade. Essa noção nos dá margem para discutir o puxirum como relação coletiva entre lavradores na formação de roçados, e prossegue no esgotamento dos meios de subsistência e na conseguinte exploração de novas "terras livres". $\mathrm{Na}$ retaguarda do processo, porém, as relações começam a se alterar, com a atuação do Estado na fundação do patrimônio e na regularização fundiária, redundando na disputa de terras por colonos japoneses que avançam das proximidades. Os tópicos assim levantados são cotejados com diferentes teorias da fronteira.

O capítulo 3 trata da formação dos mercados de terra e trabalho e do planejamento estatal na área, abrangendo um intervalo entre as décadas de 1970 e 1980. A regularização da terra oportuniza sua transação e o impulso de lavradores para pontos cada vez mais distantes da cidade, decretando a fundação de uma plêiade de novos agrupamentos rurais. Terrenos apropriados por compra são relativamente concentrados e reservados para a criação de gado, ajustando o movimento de incorporação de terras e sugerindo o debate sobre o "fechamento" da fronteira.

Ao mesmo tempo, a monetarização vai se apresentando como processo que modifica as relações de trabalho, permitindo a compra de terras e a exploração de trabalho na forma de diárias, modificando tanto relações pautadas pelo monopólio do armazém no fornecimento de mercadorias como relações de troca de serviços entre os lavradores. O emprego da força de trabalho vai se diversificando como meio necessário de aquisição de dinheiro, ainda que o lavrador se mantenha dono de seu terreno, e de modo que a monetarização põe em discussão a reposição dessa condição de lavrador e a expropriação como simplesmente expulsão da terra.

Encerramos com uma discussão acerca do Estado, por meio da análise dum programa operacional do Instituto Nacional de Colonização e Reforma Agrária (Incra) para os projetos de colonização de Monte Alegre: programa que, basicamente, almeja regular a posse fundiária e fornecer condições técnicas para o aumento da produtividade agrícola. O diagnóstico das condições de produção endossa políticas de modernização que, assente no desenvolvimento regional, nos remete à dissolução das relações que reproduzem a região econômico-política conceituada por F. de Oliveira (2008).

No quarto (e último) capítulo, avançamos para as mudanças mais recentes na fronteira, datadas a partir da década de 1990. Começamos localizando a transitoriedade da posse da terra na dependência crescente de dinheiro entre os produtores, como processo determinado pela concorrência. A possibilidade de ocupar novas parcelas de terra é prima facie impedida 
com a formação de um corredor de Unidades de Conservação, indicando outra organização do uso da terra pelo Estado. Já a migração para as cidades é interpretada junto à metropolização da vida rural, com a ampliação do consumo e a vigência de programas governamentais - com destaque para o crédito rural - que vão estipulando o dinheiro como meio indispensável e exclusivo da reprodução dos sujeitos. Quanto a isso, o oferecimento de crédito é cotejado com teorias que compreendem uma "estrutura produtiva camponesa", baseada na argumentação da sustentabilidade produtiva e ecológica, como alvo do desenvolvimento regional competitivo.

Também analisamos os conflitos por terra no PDS Serra Azul, destacando práticas que se assemelham à permanência de certas condições de reprodução, bem como iniciativas em disputa referentes à regularização da área. A questão é se tais conflitos são o deslocamento dos conflitos no sudoeste paraense, de onde parte a maioria dos grileiros das terras do PDS.

Por fim, dedicamo-nos à formação de reservas ambientais na área polemizando com a pertinência da tese da conservação como mecanismo de acumulação capitalista. A apreensão do tema como reiteração da acumulação primitiva é oposta à imposição de um limite absoluto na valorização do capital e ao endividamento estatal. Na contemporaneidade, o Estado tem suas funções ampliadas, tendendo não tanto ao fomento da expansão da ocupação fundiária por lavradores, senão mais ao confinamento destes através de políticas assistencialistas.

\section{Sobre nossos interlocutores}

Mais acima explicamos como as entrevistas são utilizadas na pesquisa. Vamos agora apresentar brevemente nossos interlocutores ${ }^{3}$. Na comunidade do Limão, aproveitamos os depoimentos de Seu Bia, Imá, Dona Celi, Seu Dubá e Dona Mazinha e Seu João André. Com exceção de Imá, que chega à área em 1986, aos 25 anos (em 2018, com 57 anos), todos são moradores residentes no povoado desde sua fundação, ou desde data próxima, revelando suas idades avançadas; chegaram crianças, e hoje contam entre meados de sessenta e setenta e poucos anos. São originários de Ourém, no nordeste do Pará, mas nascidos no Nordeste ou descendentes de nordestinos, sempre cearenses e potiguares. Dona Celi e Seu João André são casados, tal qual Seu Dubá e Dona Mazinha.

No terceiro capítulo apresentamos outras entrevistas, condizentes com os processos ali analisados. Temos em Seu Chico Bahia e em Seu Paulino personificações da expansão da ocupação fundiária e da proliferação de agrupamentos na área, enquanto Seu Kazuo disserta acerca das relações de trabalho que são levadas a cabo quando os colonos japoneses investem

\footnotetext{
${ }^{3}$ Para especificação das datas e locais das entrevistas, cf. Referências.
} 
na cultura de pimenta-do-reino. Por fim, Miguel apresenta uma de muitas posições possíveis na dinâmica de modificação das relações de trabalho entabuladas na fronteira.

No capítulo de encerramento, o irmão de Miguel, Dó, versa sobre como comercializa sua produção e nos introduz a relações estabelecidas com atravessadores, enquanto Avelino exibe sua visão do funcionamento do crédito rural. O gaúcho Jairo descreve um cenário de esgotamento do solo e de pauperização, atentando ao limite definido pela decretação de Unidades de Conservação. Já os conflitos na Serra Azul são exibidos pela narrativa de Paulinho, ex-líder da associação local que sofrera ameaças de grileiros. De outro lado, examinamos aspectos da trajetória de lavradores que discordam do plano de legalização do PDS: Lúcio e seu filho, Reinaldo, que também retratam as dinâmicas mais recentes de posseamento de "terras livres" na fronteira. 


\section{CAPÍTULO 1}

\section{FORMAÇÃO DA REGIÃO E COLONIZAÇÃO}

Nossa pesquisa documental nos conduziu à descoberta de dois profícuos relatórios do engenheiro e geógrafo paraense João de Palma Muniz (1873-1927), que fora chefe da repartição de obras públicas da Secretaria de Obras Públicas, Terras e Viação do Pará, além de membro da refundação do Instituto Histórico e Geográfico do Pará, em 1917. Devido ao cargo que exercia, participou de comissões de regularização fundiária e na delimitação de municípios e da linha fronteiriça entre o Pará e o Amazonas. As obras redigidas a partir dos serviços prestados apresentam interpretações da história territorial amazônica e permitem situar a perspectiva do autor num projeto nacional de desenvolvimento da área ${ }^{4}$. Alguns desses relatórios nos interessam diretamente, na medida em que deles traçamos um percurso de análise das transformações nas relações de trabalho e com a terra nas áreas de fronteira na margem esquerda do Baixo Amazonas no começo do século passado.

Assim, partimos da obra Immigração e colonisação (1916), acerca do planejamento e execução dos primeiros planos de colonização na área pesquisada (cap. 1.1). Seguimos (cap. 1.2) para um diálogo com o texto Castanhaes de Alemquer (1922), que examina a regulação dos terrenos de castanheiras nas margens dos rios Curuá e Mamiá, daqui abordando o conflito entre grandes comerciantes locais e a ação do Estado que Muniz representa. A última parte do capítulo (cap. 1.3), por sua vez, trata da fundação de projetos de povoamento entre as décadas de 1920 e 1940.

\subsection{Os primeiros projetos de colonização e a formação do trabalho livre no Brasil}

João de Palma Muniz (1916), em Immigração e colonisação, retraça historicamente três séculos de políticas de povoamento no Grão-Pará. O texto, em três capítulos, tem como guia o desenvolvimento econômico daquela província, da Colônia à República. Por isso, ele abre com breves considerações acerca da "época colonial”, com a formação das capitanias e a atuação de ordens religiosas na organização dos aldeamentos que originariam centros urbanos

\footnotetext{
${ }^{4}$ Até onde pesquisamos, inexiste qualquer trabalho que trate da vida ou da obra de Muniz, de maneira que as informações do corpo do texto são sintetizadas a partir da leitura de algumas das publicações do autor. Entre estas, temos: Patrimônios dos conselhos municipaes do Estado do Pará (1904); Índice geral dos registros de posse do Estado do Pará (de 1907 a 1913), em duas séries: a primeira com sete volumes, e a segunda, com dois; Índice dos títulos de terras expedidos de 1901 a 1908 (1909); e Limites do Pará e Amazonas (1937); além das que analisaremos: Castanhaes de Alemquer (1922) e Immigração e Colonisação (1916).
} 
que margeiam o rio Amazonas (ibid.: 15-7). Passando adiante, no segundo capítulo, a "época do Império", já se ordena alguma regularização fundiária e políticas de colonização. No último, o "período da república", a execução de novos e mais complexos projetos de povoamento e imigração atesta uma diferença no intento planejador.

Inclusive, pensando nessa distribuição expositiva, prevalece uma designação histórica da institucionalização do Estado, que se perfaz por meio de suas políticas. O parecer aqui analisado é uma encomenda do Serviço de Povoamento - do então Ministério da Agricultura, Indústria e Comércio - para todas as unidades da federação, e, logo pela instrução do pedido, fica nítida certa intenção de esquematizar projetos de ocupação fundiária na extensão do território dum Estado nacional em formação. É bem possível que os estudos assim levantados pudessem ser revertidos na elaboração de novos programas quanto ao uso da terra.

Em miúdos, o território que hoje é o Brasil surge da colonização como processo dotado de sentido, a saber: a exportação de mercadorias tropicais para consumo dos mercados metropolitanos, na conhecida formulação de Prado Jr. (2000). Se extrapolamos essa assertiva, alicerça a vertente agroexportadora colonial a constituição de relações determinadas pela forma mercadoria. Também é cabível grifar que igualar as políticas mercantilistas do período às medidas oficiais posteriores desprezaria a singularidade do Estado absolutista colonial face ao Estado nacional brasileiro. Nesse caso, a Independência do país se realiza como lento processo de internalização das relações metropolitanas, gestando uma classe trabalhadora através da violência disciplinadora da qual se encarrega esse mesmo Estado em formação. A premissa é a constituição de condições capitalistas de produção, que segundo Heidemann et. alli (2014: 59), se apresenta como territorialização do capital, da escala regional à nacional. Ou seja, o regional é momento do processo ao reproduzir particularidades nas relações de trabalho, sendo sua origem submetida à divisão internacional do trabalho (ibid.: 59).

Assinalemos como a instituição do Estado é especialmente flagrada mediante políticas territoriais, entre as quais a colonização. Na brochura de Muniz (1916: 22-3), os projetos de colonização são registrados como "solução" para a "falta de braços", sendo a terra "o coefficiente [...] pelo qual advém a fixação do colono". No escrutínio desses planos, o autor enfatiza a "falta [de] habitantes para povoar o solo e os braços para cultival-o", tal como o "problema financeiro" na execução da colonização e a inexistência de colônias agrícolas que sirvam de modelo para o assentamento de outras (ibid.: 21-3). É uma coleção de motivos que traz consigo uma conclusão sobre o desinteresse do governo em dar seguimento contínuo à 
colonização: careceria "a propaganda externa, a organização interna permanente e as largas vistas para a localização do immigrante introduzido" (ibid.: 53-4).

No entanto, tal contexto de formação do Estado sobrepuja o rol do desinteresse, pois remete a uma capacidade objetiva de se capitanear trabalho. A nosso ver, o esforço de estabelecer colonos está sintonizado com a organização da produção de mercadorias, segundo formas de ocupação da terra e relações de trabalho estipuladas por políticas públicas. Central à análise, no caso, é a relação da reprodução de condições de produção na fronteira com o desenvolvimento do Estado enquanto territorialização de relações capitalistas de produção.

De acordo com Muniz, em 1854 é fundada a Colônia Militar de Óbidos, a primeira na margem esquerda do Baixo Amazonas. Localizado num terreno de 8700 ha e atingindo o pico de 255 moradores, o projeto é extinto assim que os soldados são convocados para serviços em Belém, dez anos depois (ibid.: 25). Sobre o malogro, que custara à administração provincial 114:000\$000, reproduz o autor o juízo do naturalista Ferreira Penna (apud ibid.: 25):

Em Obidos, como no Araguary, alguns soldados, logo que chegaram á colonia, cuidaram de cultivar seu lote de terras; mas quando os dois delles estavam em vespera de colher os fructos que plantaram, uma simples ordem os rendeu, chamando-dos á Capital.

Não foi preciso mais um exemplo para que os soldados, sendo destruida a esperança de se fazerem proprietarios, se guardarem de formar novas plantações.

A colonização ordenada é, antes de tudo, concebida como ocupação militar que garante o domínio do Império sobre as paragens em questão. $\mathrm{O}$ encargo reservado ao soldado interessa na medida em que este, em vez de assalariado, é um colono, subordinado a uma relação de trabalho cuja reposição não é exclusivamente mediada pelo dinheiro, et pour cause o indivíduo não é expropriado de suas condições de produção. O problema orçamentário deste Estado também está em debate, pois ele não redunda no dispêndio de salários com um corpo militar, embora seja investido dinheiro em infraestrutura.

É quando aborda os primeiros núcleos de colonização civis que Muniz descreve, mais detidamente, relações de trabalho. Em 1855, nas cercanias de Belém, o cel. José do Ó de Almeida cria a Colônia de N. Sra. do Ó, na qual a meação organiza a produção:

Pelo contrato o colono recebia terras para cultivar a cana de assucar, casa de moradia, ferramentas de trabalho, passagens, comedorias e adiantamento.

As culturas eram feitas em commum tendo o proprietario a meiação, e sendo a outra metade rateada entre os colonos (ibid.: 27). 
Logo as atividades são encerradas, conforme o autor, por questão de N. Sra. do Ó não ser uma colônia agrícola, mas uma agroindústria, na qual o produtor não pode ser proprietário de lotes:

De facto, o coronel José do Ó não fundara uma colonia; creara um estabelecimento agricola industrial, para o qual contractou trabalhadores, cujo salário era a meiação das coleitas ou produção.

Ao colono não era dado um lote para nelle desenvolver sua actividade, nunca podendo ter a pretensão de se tornar proprietario, nem independente, e muito menos fixar-se no solo (ibid.: 27, grifo nosso, D.L.).

Já em 1856, a administração da Colônia prevê ao produtor a propriedade da terra após dez anos de serviço e pagamento de foro, o que não impede uma debacle geral:

Por elle tinha o colono o direito de occupar o terreno e beneficial-o, pelo systema da meação, durante o prazo de 10 annos, findos os quaes poderia adquiril-o, a título de aforamento, pagando 10 réis por braça quadrada annualmente, fôro que constituiria um verdadeiro aluguel (ibid.: 27).

O que é de se pôr em xeque, mais detidamente, é como a impossibilidade inicial de adquirir a propriedade faz do resultado do trabalho na meação um "salário" para Muniz. Ele não retorna ao problema quando discute a compra da terra pelo produtor ou quando examina outros projetos de colonização, mas parece supor relações em que as categorias do capital são dadas: o assalariamento é fruto do trabalho, independente das condições em que este ocorre e de ser ou não efetuado em dinheiro. Claro que, diga-se de passagem, a meação esconde uma relação de compartilhamento dos custos de produção do proprietário que explora o trabalho do colono - isso sem contar prováveis descontos nos gastos deste, dos quais aquele se aproveita. Classificar a relação nos termos do salariado, entretanto, exige uma reflexão mais demorada sobre a remuneração do produtor.

Uma polêmica consagrada nesse âmbito nos permite uma conciliação com a postura de Muniz. Caio Prado Jr. (1979), ao analisar que fatores atuam na oferta e demanda de força de trabalho na economia agrária brasileira, assinala que a concentração da propriedade fundiária tira do trabalhador rural "outra alternativa que não a de se pôr a serviço da grande exploração" (ibid: 58). As condições em que se realizam a remuneração desse trabalhador, porém, são variáveis, podendo-se combinar o pagamento do salário (em dinheiro) com uma parcela em produto e/ou na concessão do direito de uso - para plantio e pequena criação - de terras do proprietário rural (ibid.: 60). Nessa configuração, os colonos da cafeicultura paulista são comparados aos moradores e foreiros da lavoura canavieira, aos vaqueiros e aos meeiros que 
cultivam algodão no Nordeste. No fim das contas, tais relações de parceria tratam "sempre de modalidades de pagamentos de serviços, mesmo quando esse 'pagamento' não é em dinheiro e assume formas peculiares" (ibid.: 62). Algo que se definiria enquanto relação de locação e prestação de serviços - "seja qual for o tipo de retribuição que recebe por essa prestação" -, a fim de fixar o trabalhador à propriedade (ibid.: 62-3). Por isso que o salariado constituiria a relação "mais característica de trabalho na agropecuária brasileira", ou "norma fundamental",

de que outras modalidades de relação são apenas substitutos eventuais ditados por circunstâncias de ocasião, e particularmente pelas vicissitudes financeiras da grande exploração (ibid.: 63-4).

Visto que a parceria se resume a um expediente circunstancial, dependente de condições de exploração determinadas, o direito à participação no produto e o uso da terra do proprietário se colocam como "benefícios [...] equivalentes do salário" (ibid.: 65). O salariado enquanto relação de trabalho na agropecuária se distingue, então, dos aspectos puramente formais dessa relação de trabalho, por vezes designados como "restos feudais". Uma postura incongruente para o autor, pois que as relações em pauta estão assentadas num mercado livre de trabalho, e não em estatutos pessoais (ibid.: 66). Temos que a resposta, todavia, ao passo que busca situar o salariado como norma das relações na agropecuária brasileira, de maneira descuidada pode engessar particularidades, correspondendo-as a um mesmo modelo explicativo.

Já na interpretação de Martins (1979) do colonato na cafeicultura paulista, o acesso parcial do produtor aos meios de produção tem uma conotação distinta, segundo o postulado da "produção capitalista de relações não capitalistas de produção". É uma formulação atinente ao contexto da passagem do escravismo ao trabalho livre no Brasil, que não consiste na generalização do assalariamento. Pelo contrário,

Esse elenco de vínculos monetários, não monetários e gratuitos e o caráter familiar do trabalho do colono não permitem que se defina as relações de produção do regime de colonato como relações capitalistas [...] Ao produzir uma parte significativa dos seus meios de vida, em regime de trabalho familiar, o colono subtraía o seu trabalho às leis de mercado e de certo modo impossibilitava que esses meios de vida fossem definidos de conformidade com os requisitos de multiplicação do capital (ibid.: 85).

Nesse caso, indagamos se uma conformação não capitalista do colonato acaba por admitir uma essência do trabalho em sua forma familiar, relegando o trabalho como substrato da sociabilidade moderna, estritamente; um problema que abordaremos mais a frente (cap. 2.3). 
É oportuno reter da discussão supramencionada que, seja a equivalência de formas distintas de remuneração, na agropecuária brasileira, ao salariado, seja o caráter não capitalista dessas relações de trabalho, não são nem falsas nem suficientes em si. São visadas contraditórias de um mesmo processo levantado como questão.

Portanto, para continuarmos a nos cercar da constituição duma massa de trabalhadores livres no país, resgatemos alguns preceitos da Lei geral da acumulação capitalista de Marx (1. I t. II, 1986, cap. XXIII). Nesse capítulo, a reprodução ampliada de capital implica tanto a formação da classe trabalhadora quanto a produção de população excedente num dado território, referente às oscilações de demanda por força de trabalho nos ciclos nacionais de acumulação (ibid.: 187). Onde os pressupostos do capital estão instituídos, o desenvolvimento da acumulação pela maquinaria enseja a produção de mais-valia relativa e a expulsão de trabalhadores do processo produtivo. A população trabalhadora cresce mais rapidamente que o emprego de trabalho vivo, gerando uma população relativamente supérflua ou subsidiária à valorização. E trabalhadores excedentes à acumulação integram uma superpopulação relativa à necessidade média de valorização; um exército industrial de reserva sempre disponível para exploração (ibid:: 201).

Esses pressupostos, ou seja, massas de capital e de trabalhadores, são historicamente formados na assim chamada acumulação primitiva (ibid.: cap. XXIV), mas não da mesma maneira nem em todos os lugares ao mesmo tempo. Nas palavras de Marx,

[...] a história de expropriação da base fundiária do produtor rural, do camponês, base do processo, assume coloridos diferentes nos diferentes países e percorre as várias fases em sequência diversa em diferentes épocas históricas. Apenas na Inglaterra que, por isso, é tomada como exemplo, mostra-se em sua forma clássica (ibid.: 263).

Na América portuguesa, a acumulação primitiva tem um "colorido" distinto, porém parte da acumulação capitalista mundial que se mostra classicamente na Inglaterra. Uma ponderação como esta balizaria a tese do sentido profundo da colonização de Novais (1983), na qual o sistema colonial é peça constitutiva da acumulação primitiva ocorrida na Europa ${ }^{5}$. No vale

\footnotetext{
${ }^{5} \mathrm{O}$ autor é mais preciso na definição de sua tese, talvez, na seguinte passagem: “Examinada, pois, nesse contexto, a colonização do Novo Mundo na Época Moderna apresenta-se como peça de um sistema, instrumento da acumulação primitiva da época do capitalismo mercantil. Aquilo que, no início dessas reflexões, afigurava-se como um simples projeto, apresenta-se agora consoante com processo histórico concreto de constituição do capitalismo e da sociedade burguesa. Completa-se, entrementes, a conotação do sentido profundo da colonização: comercial e capitalista, isto é, elemento constitutivo no processo de formação do capitalismo moderno" (Novais, 1983: 70).
} 
amazônico em sua extensão, o "colorido" assumido se dá pela colonização como produção de mercadorias tropicais, com a escravização do indígena e do negro africano. No caso narrado por Prado Jr. (2000, cap. X), a extração das “drogas do sertão" organiza um sistema assentado no percurso fluvial, com captura e trabalho forçado de indígenas por sertanistas. Ou então, com o "descimento" e imposição de união de diferentes grupos étnicos numa mesma aldeia por ordens religiosas, ainda se destacando a construção de fortes que demarcam o domínio territorial da Coroa portuguesa. Essa territorialização colonial do capital (Toledo, 2008) e a reprodução de suas particularidades, pois, não ocorrem sobre um vazio.

Na obra de Marx (1. I t. II, 1986: 198), a acumulação num contexto de origem colonial não passa pela produção de exército industrial de reserva, demandando a criação, por meios artificiais, de uma classe trabalhadora prontamente explorável. Nesses termos é que o autor trata da teoria moderna da colonização (ibid., cap. XXV), baseado na elaboração da colonização sistemática de E. Wakefield. Pretensamente contra a livre posse da terra pelo produtor, que então enriqueceria a si mesmo em vez de ao capitalista (ibid.: 295), a meta da colonização consiste em patrocinar a expropriação do produtor de suas condições de produção. Para tanto, o Estado deve regularizar a terra e lhe fixar preços tão suficientemente altos que forçam o trabalhador ao assalariamento, ao menos até o instante de ser substituído por outro (ibid:: 300).

Em nossa leitura, a colonização sistemática tem como intenção formar uma população trabalhadora segundo um modelo de reprodução do capital, modernizante. Aqui, o conceito de modernização recuperadora de Kurz (1992) é pertinente ao passo que expressa a busca, pelo Estado em formação, por um padrão acumulativo estipulado pela concorrência global. Parte integrante desse projeto, no Brasil, é a instituição da Lei de Terras de 1850, na conjuntura da crise das relações escravistas e formação do trabalho livre, conferindo preços à terra devoluta. A força de trabalho assim formada é duplamente livre, para ser vendida e livre dos meios de produção, assim granjeando seu atributo específico de mobilização do trabalho ${ }^{6}$ (Gaudemar, 1977). Como condição, o domínio colonial sobre a terra, através do poder de concessão das sesmarias, dá lugar, com a Independência, a processos de instituição jurídica da terra como mercadoria. Sobre isso, podemos pontuar que as interpretações dos efeitos da Lei de 1850

\footnotetext{
${ }^{6}$ Em Gaudemar (1977), a mobilidade é característica singular da mercadoria força de trabalho, que, quando consumida, fundamenta valorização capitalista: "A mobilidade da força de trabalho é assim uma 'característica' do trabalhador submetido ao capital e por essa razão do modo de produção capitalista. Ela funda a condição de exercício da força de trabalho como mercadoria, distinguindo assim definitivamente o trabalhador 'livre' do escravo cuja capacidade de trabalho é estável e só se emprega de maneira tradicional e local, de uma vez por todas" (ibid.: 192).
} 
variam, sumamente, entre a proposição da imposição da grande propriedade fundiária e a possibilidade da regularização dos terrenos de antigos posseiros ${ }^{7}$. De todo modo, se à terra é legada o estatuto de propriedade cujo acesso é restrito à compra, seria preciso avaliar se a Lei teve alguma consequência prática em todo o território nacional ao mesmo tempo ${ }^{8}$. Isso porque o desenvolvimento capitalista no país, consideramos, se realizava extensivamente, ou seja, incorporando novas terras como processo de expansão da fronteira.

É possível apreciar a teoria moderna da colonização de Marx observando na fronteira a base fundiária não monopolizada por uma classe de proprietários. Por isso, a terra passaria por medidas de regularização, pelo Estado, que interditariam aos lavradores o usufruto direto dos meios de produção. A tensão da regulação da posse como propriedade privada da terra é, nesses termos, necessariamente conflituosa.

Pois bem. Muniz (1916: 54) justifica que, até a proclamação da república, jamais se coordenara no Grão-Pará um serviço sistemático de colonização. Só após a transferência das terras devolutas da federação para os estados, em 1891, é que seriam concebidas novas colônias agrícolas. No autor, a jurisdição das terras pelos estados oportuniza uma elaboração mais atenta a condições de produção locais, expressas como "exigências do meio e do clima":

Entregues ao domínio dos Estados as terras devolutas, em relação ao importante problema da colonisação, ficava o Estado com a base mais importante do serviço de colonisação, que é a terra, na qual poderia escolher, separar e dividir, e crear um regimen colonial segundo as mais adequadas exigencias do meio e do clima (ibid.: 63).

E mais:

Até o anno de 1894 não teve, póde-se dizer, o problema conjunto de colonisação e immigração no Grão-Pará, uma systematização, uma lei creadora inicial e uma regulamentação geral (ibid.: 66).

\footnotetext{
${ }^{7}$ Como representantes respectivos das duas concepções, temos que, para Ariovaldo U. de Oliveira (2007: 148), a Lei se faz contrária ao conteúdo da pequena posse de terras e a favor do latifúndio, afinada a versão com seu posicionamento de classe: a favor do que designa como campesinato e contrário ao fazendeiro e empresário agropecuário. Já para Rui C. Lima (2002: 51-2), a posse como recurso legítimo de aquisição de domínios, desde que cultivada, teria com a Lei seu reconhecimento jurídico, o que convidaria a um debate da posse da terra em relação ao regime sesmarial colonial, ultrapassando o escopo desta dissertação. Ainda, para Martins (1979: 29 e 59) a Lei se realiza como expediente de submissão de força de trabalho ao fazendeiro, também reconhecida, aí, uma visão de classe.

${ }^{8}$ Sobre as consequências da Lei de Terras, Lima (2002: 92) afirma não terem surtido como esperado devido à "negligência da organização". Na Amazônia, Roberto Santos (1981: 9 apud Musumeci, 1988: 44) expõe que na década de 1890 a ocupação da terra continua basicamente efetuada pela posse, o que sem dúvida põe em xeque a efetividade do decreto. Mas não descartamos que a simples existência da Lei traz consequências às formas como se concebe e realiza a apropriação de terras no país.
} 
Em 1894, com a promulgação da Lei n. 223, os planos de povoamento são delineados em proveito do estabelecimento de imigrantes que pretendem se fixar como agricultores ou industriais, prevendo uma série de benefícios, a incluir indenização das passagens, transporte gratuito, tratamento médico e entrega de terreno (ibid.: 67). A lei autoriza a criação de núcleos coloniais, com concessão de benesses no transporte de bens de lavoura em burgos agrícolas, e a redução em $60 \%$ no preço das terras devolutas (ibid.: 67). Quase a totalidade dos imigrantes trazidos é de portugueses e de espanhóis, a serem abrigados em dez núcleos recém-criados, entre os quais o de Monte Alegre. Consta, no escrito, dezesseis instruções para a regulação dos colonos deste núcleo, com relevo para a instalação de uma "comissão de trabalhadores" para picada e derrubada da floresta e a repartição equânime dos terrenos; no caso, seguindo padrões de medida e localização predeterminados e com a frente voltada para cursos d'água e estrada, com dimensões de $250 \mathrm{~m}$ x 1000m. Cada território abarcaria cinquenta lotes e um perímetro urbano, cortados por vicinais de $2 \mathrm{~m}$ e rodovia de $4 \mathrm{~m}$ de largura ${ }^{9}$. Além disso, o autor informa a nomeação do engenheiro Antonio M. Barata como o primeiro inspetor de colonização de Monte Alegre, a comandar o estudo da fundação dos núcleos de Igarapé-Açu e de Itauajuri, nas fraldas de serra homônima (ibid.: 75). Nessa etapa inicial, desembolsaria o governo 151:364\$021 sobre uma área de 3675 ha, dividida em 147 lotes agrícolas de 25 ha e uma gleba de 213 terrenos com 23 quarteirões ${ }^{10}$ (ibid.: 77).

Chamamos a atenção para um paralelo, viável, entre a concessão de benefícios para imigrantes e os postulados da colonização sistemática, de Wakefield, sintetizados com a Lei de Terras. Em sua interpretação dessa síntese, Lima (2002: 92) aponta que a "mão de obra das colônias agrícolas" pode ser importada com os fundos adquiridos da venda de terras a outros

\footnotetext{
${ }^{9}$ Resumimos a lista de instruções da seguinte forma: 1. Comissão composta por inspetor, agrimensor e dois auxiliares, tendo à disposição pessoal para trabalhos de picada e derrubada; 2 . Zonas exploradas ao norte do Airy e os marginais à Serra do Itauajuri, e terrenos devolutos além do Ererê, na Terra Preta; 3. Comissão deve atentar à natureza das terras e à disponibilidade de água; 4. Tentar manter os terrenos todos na mesma configuração; 5. Deve ter o terreno $250 \mathrm{~m}$ x 1000m, sendo a frente voltada a cursos d'água e estrada; 6 . Cada território deve ter área suficiente para pelo menos 50 lotes; 7. Deve ser reservada área para ser dividida em lotes urbanos; 8. Os lotes urbanos deverão ter $30 \mathrm{~m} \times 60 \mathrm{~m}$ de fundo, ou $20 \mathrm{~m} \times 90 \mathrm{~m}$, formando quarteirões de $180 \mathrm{~m}$ de lado; 9 . Vicinais devem ter $2 \mathrm{~m}$ de largura; 10 . As estradas de rodagem devem ter $4 \mathrm{~m} ; 11$. Quando houver conflito da terra devoluta com particular, deve-se abrir edital; 12 . 0 inspetor da comissão está investido da atribuição de medir terrenos no caso da disputa do mesmo entre dois posseiros; 13 . Os colonos não podem se localizar nos lotes sem autorização da Diretoria da Repartição de Obras Públicas, Terras e Colonização; 14. 0 inspetor da comissão deve enviar mensalmente um relatório constando os serviços prestados e trimestralmente um mapa, cartas e documentos relativos aos serviços; 15 . Todos os trabalhos devem ser remetidos à Repartição de Obras Públicas; 16. A falta de cumprimentos das obrigações por parte do inspetor importa na imediata suspensão de seus vencimentos (Muniz, 1916: 75).

${ }^{10}$ Acerca da distribuição da população nessa colônia agrícola, encontramos na obra Colonização do Pará, do historiador Ernesto Cruz (1958), uma tabela que discrimina as nacionalidades dos colonos. Em 1898, tínhamos 145 colonos espanhóis e 31 nacionais; em 1900, 248 espanhóis e 310 nacionais; e em 1902, 201 espanhóis e 331 nacionais - 258 cearenses, 23 potiguares, 50 paraibanos (ibid.: 118-9).
} 
colonos. Quanto a isso, é nítida a participação da imigração na constituição do trabalho livre no Brasil. Por força de políticas de subvenção, o Estado investe na tentativa de criar um contingente de força de trabalho coibido do acesso a seus próprios meios de produção. Porque a força de trabalho formada pretendia ser basicamente composta por europeus pode ser, em partes, argumentado com a apresentação dos recursos de expropriação acionados no Velho Mundo $^{11}$. Porque os trabalhadores livres não são ex-escravos, por sua vez, conduz ao racismo e a medidas de eugenia que esperavam criar uma nação de trabalhadores pela exclusão do negro $^{12}$. A mudança do "colorido" que deve assumir a acumulação é inegável, mas reter-se unicamente a isso pode deixar de contemplar um aspecto incontornável da forma com que se dá a modernização do país: a demanda crescente de trabalho para impulsionar extensivamente a ocupação de terras.

E parte desse intento de ocupação se traduz nos núcleos de colonização de Óbidos e Alenquer, ambos de 1898 (Muniz, 1916: 87-8). Respeitante ao primeiro projeto, praticamente um natimorto de um ano de vigência e que deixa prejuízos de 109:647\$306, opina Muniz:

[ ...] a falta de immigrantes, as más condições em que estava o nucleo por sua posição em relação ao abastecimento de agua determinaram a sua extincção em 1899.

Para ele entraram 9 famílias com 51 pessoas, que no acto da extinção passaram para o núcleo Santa Rosa, na Estrada da Vigia (ibid:: 87-8).

Condição diferente da colônia de Alenquer, descrita como "summamente futuros[a]":

O núcleo de Alenquer está situado no Municipio do mesmo nome, á margem da estrada que partindo da cidade de Alemquer dirige-se para os Campos

\footnotetext{
${ }^{11}$ Na perspectiva de Martins (1979: 60-1), o europeu expropriado tornava-se colono no Brasil para afirmar sua ideia de liberdade a partir da propriedade de seu trabalho, ao passo que, para o escravo, ser livre era poder "nada fazer", ou seja, não se submeter ao trabalho que antes o dilapidava. A tese de Boechat (2013: 169), a respeito do colonato e da expansão da citricultura no Oeste paulista, discute a expropriação na Europa localizando-a na totalidade da sociedade produtora de mercadorias, em que se inscreve centro e periferia: no Velho Mundo, ainda se formava uma superpopulação relativa nacional que bem poderia seguir para a América. Explicação que, a nosso ver, explicita o fundamento social do processo de acumulação de capital e de formação da população trabalhadora, ultrapassando a redução do problema à polarização ideológica da liberdade. Além do mais, a própria figura do escravo de ganho no século XIX faz da suposição de Martins um contrassenso: como poderia o negro trabalhar para afirmar sua liberdade se ser livre é, necessariamente, não trabalhar? Sobre o escravo de ganho e sua relação com o trabalho livre em gestação no Brasil, cf. Toledo (2008, cap. 3.3).

${ }^{12}$ Diga-se de passagem, Lília Schwarcz (2005) problematiza a aceitação e adaptação das teorias raciais no Brasil no contexto da desmontagem da escravidão, divulgação do ideário positivo-evolucionista e ampliação de centros de pesquisa nacionais. Tais teorias forneceriam um modelo que justificava o jogo de interesses que então se montava: "Para além dos problemas mais prementes relativos à substituição da mão-de-obra ou mesmo à conservação de uma hierarquia social bastante rígida, parecia ser preciso estabelecer critérios diferenciados de cidadania. É nesse sentido que o tema racial, apesar de suas implicações negativas, se transforma em um novo argumento de sucesso, para o estabelecimento das diferenças sociais" (ibid.: 19-20).
} 
Geraes da Guyana Paraense, e desdobra-se em uma extensão longitudinal de 14 kilometros.

É summamente futuroso, pela fertilidade das terras em que se acha.

Com elle despendeu o Estado a quantia de 111:507\$748 (ibid.: 88).

Vai ficando mais claro como o Estado deve se instituir sendo proprietário de dinheiro, aplicado na manutenção dos núcleos coloniais, que pressupõem uma população o suficiente para sustentar a produção agrícola da área. A origem desses fundos é pouco discernível: se a fonte é a tributação de cidadãos, a captação de empréstimos ou o próprio fundo migratório não nos parece algo passível de designação. De todo modo, a suspensão dos contratos com empresas de colonização em 1900 e o corte na alocação de imigrantes demonstram, pelas lentes de Muniz, como é onerosa a manutenção dos núcleos (ibid.: 93). Daí, a contenção dos benefícios às famílias assentadas representa forte fator de êxodo, o que motiva, em resposta, a concessão gratuita dos mesmos lotes a migrantes nacionais:

Cessados os favores do governo ás familias immigrantes extrangeiras, localisadas nas colonias e considerando cada uma que o prazo de cinco annos para o pagamento da quantia de $800 \$ 000$, estipulada pelo art. $5^{\circ}$ da lei n. 583 , de 21 de junho de 1898, estava em decorrencia, principiaram os colonos a abandonar os respectivos lotes.

Já nos fins de 1901 o exodo era importante, principalmente por parte das familias extrangeiras.

Urgía tomar uma deliberação no sentido de evitar que as colonias ficassem despovoadas.

Resolveu a administração publica admittir nellas familias nacionaes e conceder o lote gratuitamente, exigindo apenas a permanencia nelle durante dois annos (ibid.: 98-9).

Retomando o argumento geral da obra, a alegação do engenheiro tanto para o plano de fundação quanto para a efemeridade da fixação dos produtores é de "falta de braços" e de incentivos ou organização por parte da administração pública. Já a "justificativa do governo", como reproduz o historiador Ernesto Cruz (1958: 118) em Colonização do Pará, encontra-se no êxodo populacional e na "psicologia do colono". Salientamos que em ambos os casos a questão tende a se estreitar à força de trabalho e à viabilidade do emprego produtivo da terra. Mas é claro que não decididamente a urgência de trabalhadores era suprida por estrangeiros, concentrados em torno do complexo cafeeiro, no qual fazendeiros e governo - composto em 
boa parte por cafeicultores - subsidiam o deslocamento e a instalação de imigrantes (Martins, 1979). Enquanto isso, dirigem-se aos seringais amazônicos principalmente nordestinos ${ }^{13}$.

Em Formação econômica do Brasil, Celso Furtado ([1959] 1984) reputa ao "problema da mão de obra" as dificuldades com que se deparava historicamente o aproveitamento dos produtos da floresta amazônica. Partindo do ponto de vista da demanda externa, o incremento da exportação de borracha dever-se-ia, exclusivamente, "ao influxo de mão de obra", uma vez que "os métodos de produção em nada se modificaram” (ibid.: 131). Dessa feita,

Essa enorme transumância indica claramente que a fins do século passado [XIX] já existia no Brasil um reservatório substancial de mão de obra [...] Aparentemente, a imigração europeia para a região cafeeira deixou disponível o excedente de população nordestina para a expansão da produção da borracha (ibid: : 131-2).

No atual Nordeste, desde meados do século XVII a crise da lavoura açucareira liberava contingentes convertidos a uma economia de subsistência que crescia extensivamente, mas resultava, em algumas áreas, numa crescente pressão demográfica sobre a terra (ibid.: 133). A nova escalada da produção algodoeira, na década de 1860, e a grande seca de 1877 são fatores que, para o autor, desequilibram estruturalmente a subsistência dos nordestinos, algo que também embasa o deslocamento destes, incentivados pelos governos amazônicos (ibid.: 133).

Entretanto, ponderamos que a noção de "economia de subsistência" existente na obra é no mínimo criticável, na medida em que abstrai as relações determinadas pela produção de mercadorias. Argumentação que leva Furtado a concluir, a respeito da subsistência, como "regressão", e a decadência na exportação de borracha como "um enorme desgaste humano" (ibid.: 135). A despeito disso, temos que expectativas de formação de uma classe trabalhadora nacional poderiam ser lidas com a exposição das relações de produção no Nordeste e a capacidade de empregar nordestinos na solução do "problema da mão de obra" na Amazônia,

\footnotetext{
${ }^{13}$ Segundo o volume Um século de imigrações internacionais na Amazônia brasileira (1850-1950), de Marília F. Emmi (2013), "foram as riquezas decorrentes da economia da borracha que fizeram da Amazônia o destino temporário ou definitivo de diversas trajetórias migratórias" (ibid.: 19). A autora divide a exposição de seu livro entre as correntes migratórias portuguesa, espanhola, sírio-libanesa e japonesa, sendo que os primeiros se concentraram nas cidades, enquanto os espanhóis e os italianos foram designados para as colônias agrícolas; os sírio-libaneses se dedicavam ao comércio nas grandes praças comerciais ou eram "regatões", mascates que se enveredavam em canoas para o interior da floresta; os japoneses, por fim, chegaram mais tardiamente, alocados em projetos colonizadores de capital privado e estatal. Sabemos que espanhóis foram destinados para a Colônia de Monte Alegre - em 1900, em número de 248, dividido em 53 famílias (Muniz, 1916: 92-3) -, mas também encontramos italianos nas colônias de Óbidos e Alenquer e na cidade de Juruti (Emmi, 2013: 118). Quem visita Monte Alegre, depara-se com alguns descendentes de sírio-libaneses, cuja presença é notável na titulação de prédios públicos, e japoneses, dedicados à agropecuária. No capítulo 3 nos deteremos com maior atenção à imigração japonesa, com um recorte voltado às relações de trabalho.
} 
sendo fomentada a migração pelo Estado e por grandes seringalistas. A territorialização do capital por meio da formação do Estado se realizaria com a interiorização dos padrões de produção ditados globalmente, na demanda da indústria automobilística em expansão por látex. Mas tal interiorização se impõe reproduzindo contradições imanentes à totalidade da reprodução do capital, movendo relações de trabalho particulares.

A rigor, a margem esquerda do Baixo Amazonas não conta com uma quantidade expressiva de seringueiras, o que não significa o isolamento da área diante da dinâmica da produção gomífera. Segundo a monografia História de Monte Alegre, de Ferreira Reis (1949), deste município e de seus vizinhos evade um grande contingente em direção aos seringais do alto Tapajós e alto Xingu, ocasionando um relativo abandono da pecuária e do extrativismo de cacau (ibid., cap. 7). No mesmo contexto, o autor menciona um código de concessão de terras e de facilidades na abertura de casas comerciais, que tinha como intuito atrair população e repovoar a cidade (ibid:: 49). Salvo engano, a referência é aos planos de colonização que analisamos. Daqui, é possível assinalar que as políticas se efetivam em relação contraditória com pressupostos da produção já reproduzidos na área, sobre os quais nos deteremos a seguir.

\subsection{Dinâmicas regionais e o aviamento nos castanhais de Alenquer}

Castanhaes de Alemquer é uma obra redigida por Muniz (1922) a partir de sua viagem pelos rios Curuá e Mamiá entre o fim de agosto e meados de setembro de 1921, cujo objetivo era regularizar castanhais reclamados pela prefeitura e por particulares. $\mathrm{Na}$ abertura e ao fim do escrito, o autor relata sua breve estadia nas colônias agrícolas da área: primeiro, ele é designado para verificar, na Colônia Itauajuri, em Monte Alegre, experimentos com o cultivo de trigo. Ocorre que as sementes, enviadas pela secretaria geral de agricultura do estado, nunca foram aproveitadas, além de constar que a sede do núcleo estava abandonada (ibid.: 8). Mas os lotes rurais estariam todos ocupados, mesmo que ainda não efetuada a regularização prevista. Isso porque, com a transferência da administração desse núcleo do estado para o município, em 1900, os terrenos não estavam sendo titulados nem se situavam onde outrora fora presumido pelo plano de colonização, levando Muniz a listar as famílias assentadas e a solicitar a regulação da área (ibid:: 8).

Até aqui, a atuação do funcionário como agente do Estado restringe-se à averiguação e à tentativa de documentação da terra. $\mathrm{O}$ Estado se institui contraditoriamente e através de suas personificações de maneiras variegadas. Quanto a Muniz, não parece estranho associar sua atuação à crença na salvaguarda da ocupação produtiva da terra, o que também endossa 
julgamentos depreciativos de sua parte. No que respeita à Colônia Paes de Carvalho, em Alenquer, persiste a seguinte avaliação:

essa colonia, fundada em férteis terras, se me apresentou em verdadeiro estado de definhamento, causado principalmente, a meu ver, pelo péssimo estado em que a ultima administração municipal deixou resvalar a estrada de rodagem de ligação da colonia com a séde do Municipio (ibid:: 53).

Há uma notória preocupação com as condições de escoamento e comercialização do cultivo, mas algo que o espanta ainda mais é que o intendente local "tudo fazia cobrar, quanto á producção colonial, desde o humilde cacho de bananas até á farinha, o milho, a rapadura, etc." (ibid.: 53). Basicamente, os problemas do núcleo aludem à má gestão dos recursos estatais, que, por exemplo, poderiam ser revertidos na melhoria das estradas e no atendimento aos colonos. A premissa é a "fructificação dos dinheiros públicos, empregados na nossa expansão territorial e de populações"; daí a lamentação com "o descaso em que se acha aquelle nucleo colonial, no qual foram despendidas largas somas, e hoje abandonado" (ibid.: 53).

Ao fundo de lotes recém-ocupados havia castanhais "explorados por simples invasão", e enquanto Muniz verificava tais terrenos, esteve acompanhado por "12 anjos da guarda":

Não posso deixar de mencionar que também nessa excursão de serviço, fui acompanhado por 12 anjos da guarda do Snr. Santos Amaral, porquanto, ao meu encalço mandou [...] todos de rifle a tiracollo (ibid.: 53).

Com efeito, o autor reconhece que a intimidação ambicionava frustrar seus trabalhos, sendo "a ultima cartada contra o desempenho da minha [dele] commissão" (ibid.: 54). Por que motivo há a ameaça? Ao que parece, Santos Amaral possuía jagunços a seu serviço e estava interessado no impedimento da regularização das áreas de castanhal. Nesses termos, o boicote à inspeção de Muniz indica a conservação de determinadas relações de dominação. Melhor dizendo, indica um conflito: a dominação que relaciona castanhal e núcleo colonizador tem a terra como mote e se debate contra a perícia delegada a nosso interlocutor.

Tanto que o relatório recorrentemente volta aos obstáculos postos sobre a tarefa de averiguação. Logo que desembarca em Alenquer, Muniz é alertado que sua "missão talvez não tivesse realisação, porquanto havia proposito determinado de impedil-a" (ibid.: 9). Uma vez que os envolvidos nos estorvos são os interessados nos terrenos, existe a suposição de que se trata de um recurso de perpetuação da configuração fundiária então vigente ${ }^{14}$ (ibid.: 11).

\footnotetext{
14 "Devo dizer que os que mais reclamavam e reclamaram sobre as terras de castanhaes, no Município de Alemquer [...] foram os que mais procuraram dificultar a missão desse funcionário, na esperança, talvez, de ver
} 
Convidados pelo engenheiro, os provocadores acompanham a verificação dos castanhais; não raro, são homens condecorados com títulos da Guarda Nacional - dois dos quais ocupantes de cargos públicos, como intendente municipal e prefeito de segurança pública - e exportadores de castanha (ibid.: 11).

O mais exaltado dos viajantes é o mencionado Santos Amaral, por sinal proprietário da maior firma do município, junto à A. Vallinoto \& Cia. de Fernandes Nunes (ibid:: 11). Para começar, no momento de partida das embarcações rumo ao Curuá, tal comerciante impõe a Muniz não levar instrumentos de medição, e tiros de rifles são disparados (ibid:: 13). Na manhã seguinte, ele ameaça os trabalhos alertando um possível levante dos "Pretos do Pacoval". Enfim, ao aportar a expedição na vila de Pacoval, alguns dos que antes escoltavam o grupo já aguardavam a execução dos levantamentos ovacionando (ibid.: 15):

No barranco desse povoado e dentro do batelão da lancha estavam reunidos mais de quarenta pretos, chefiados por Gumercindo Magalhães, que principiou a dar vivas ao Snr. Santos Amaral, ao Dr. Governador do Estado, ao prefeito de segurança publica, ao Dr. Palma Muniz, aos pretos do Pacoval, a liberdade do rio Curuá, aos castanhaes livres, vivas esses correspondidos pelos pretos.

No decorrer do relato, as aclamações são reiteradamente proferidas. No que toca ao fragmento acima, distinguimos um segmento referido a pessoas e grupos e outro a locais. Tudo se passa como se operasse uma rivalidade, amistosamente velada por assim dizer, entre o agente estatal e as personas da área, que prezam pela "liberdade" dos castanhais do Curuá.

Sugerimos que as posições que ocupam os comerciantes, como detentores de poder de decisão sobre a produção, vinculam-se ao comando sobre a força de trabalho na área. No tratamento de Chico de Oliveira (2008), estaria aqui ressaltada a dimensão política da região, ou seja, “de como o controle de certas classes dominantes 'fecha' a região" (ibid.: 151):

O "fechamento" de uma região pelas suas classes dominantes requer, exige e somente se dá, portanto, enquanto essas classes dominantes conseguem reproduzir a relação social de dominação, ou mais claramente as relações de produção. E, nessa reprodução, obstaculizam e bloqueiam a penetração de formas diferenciadas de geração do valor e de novas relações de produção.

A inspeção para regularização das terras de castanhais - e também as políticas de colonização - podem ser detectadas como um primeiro esforço na supressão das relações capitaneadas pelas classes dominantes regionais. Daí, por um lado, o conflito. Por outro, se alguns 
membros dessa classe ocupam cargos públicos, as relações entre Estado e região não parecem muito bem discernidas, ou estão de acordo entre si.

Diante das ameaças sofridas no Pacoval, Palma Muniz (1922: 14) propõe atender às demandas dos moradores quando retornasse descendo o Curuá. Ao prosseguir, chega ao Canta Galo, onde é surpreendido, à noite, pelos residentes do Pacoval tentando tomar a embarcação e inspecionar o serviço efetuado, enquanto S. Amaral e o chefe de segurança municipal já se situavam em outra comunidade. O narrador entende o acontecido como um plano de Amaral para prejudicar a comissão, e surpreende-se com a submissão do chefe de segurança às vontades do comerciante, concluindo:

Senti, em todos esses factos, como funccionario do Estado, ter de constatar a subalternidade inexplicável da autoridade de segurança mais importante de Alemquer no exercício de suas funções a indivíduos desclassificados na hierarchia administrativa do Estado (ibid.: 18).

Um fator que percebemos é como ser comerciante confere a Amaral o poder de, ao menos em partes, controlar a decisão dos agentes do Estado regionalmente, corroborando com a perplexidade do autor diante de alguma confusão entre as esferas pública e privada e entre o econômico e o político, que ele esperava encontrar separados, quiçá. Na região, conforme Oliveira (2008: 148), economia e política devem aparecer fusionadas como pressupostos da reposição capitalista na área:

seria, em suma, o espaço onde se imbricam dialeticamente uma forma especial de reprodução do capital e, por consequência, uma forma especial da luta de classes, onde o econômico e o político se fusionam e assumem uma forma especial de aparecer no produto social e nos pressupostos da reposição.

A ostentação da aparente autonomia entre política e economia é um postulado que subsiste mais ao Estado e a quem o personifica como funcionário que, talvez por isso, naturaliza tais divisões. Dessa forma, a visão de Muniz não se distancia daquela de Victor Nunes Leal (1975), que, em seu conhecido estudo sobre o coronelismo, concebe tal sistema como "incursão do poder privado no domínio político". Mas um poder privado decadente, firmado numa relação de compromisso com o poder público fortalecido (ibid:: 251-2). Com isso, o autor situa o coronelismo historicamente, pois não se trata nem do patriarcalismo colonial nem da "poderosa influência que, modernamente, os grandes grupos econômicos exercem sobre o Estado" (ibid.: 251). Mesmo que o compromisso firmado presuma "certo grau de fraqueza de ambos os lados" (ibid.: 252), ele enxerga positivamente uma regulação 
política centralizada no Estado - representante da esfera pública. É por tal motivo que, na leitura de Toledo (2008: 214), Leal deixa de indagar a aparente oposição entre público e privado como modernamente constituída ${ }^{15}$.

Agora, abordemos os "Pretos do Pacoval" e sua relação com as dinâmicas discorridas. Segundo Muniz, o povoado do Pacoval era um antigo mocambo, que até 1870 era o ponto mais longínquo de exploração de castanha nas margens do Curuá (Muniz, 1922: 19). No livro Negros do Trombetas, Rosa E. Marin e Edna M. Castro (1997) investigam as "comunidades remanescentes de quilombos" e as lutas destas frente aos projetos minerais e hidrelétricos dos trechos acima das cachoeiras do rio Trombetas. Tencionando sublinhar uma "exclusividade negra" na área, as autoras buscam, ali, os antecedentes e a tradição de ocupação por esses grupos e seu "nível de integração na economia regional" (ibid.: 41). Tal exclusividade se dá pelo tempo de ocupação da bacia do Trombetas e pela importância econômica e demográfica dos quilombos (ibid:: 41). A história é reconstituída a partir das memórias dos ajuntamentos, existentes desde pelo menos a metade do século XVIII, com a fuga de escravos dos cacauais de Alenquer, Óbidos e Santarém que, mormente, subiam o rio Curuá e seguiam em direção ao Trombetas e a lagos e igarapés próximos ${ }^{16}$ (ibid.: 41-3).

$\mathrm{Na}$ obra, verificamos que logo após a Independência, os escravos em Monte Alegre compunham $14 \%$ da população, enquanto representavam 26,7\% em Alenquer e 30,2\% em Óbidos (ibid.: 50), empregados nas fazendas de gado, nos cacauais e nas lavouras de algodão, milho e feijão, que, não obstante diversificadas, eram "pouco produtivas" (ibid.: 54) ${ }^{17}$. Em seguida, as pesquisadoras dissertam como, em meados do século, as atividades extrativas e agropastoris "recuperaram timidamente" a economia do Baixo Amazonas, devido à expansão da ocupação "branca" de terras devolutas:

As atividades extrativas e agropastoris que recuperaram timidamente a economia do Baixo Amazonas, acomodaram-se à ampliação do espaço

\footnotetext{
15 “Tendo percebido o processo contraditório da formação institucional do Estado brasileiro, o autor [Leal] parte da oposição público-privado sem criticá-la como historicamente determinada pelo processo de modernização. Neste processo, o Estado - face pública - autonomiza-se, até certo ponto, da acumulação do capital; e o capital autonomiza-se, de maneira relativa, do uso direto da violência por sua face privada. $\mathrm{O}$ autor parece crer na possibilidade de uma esfera pública legalmente regulada, apesar da menção à poderosa influência que, modernamente, os grandes grupos econômicos exercem sobre o Estado" (Toledo, 2008: 214).

16 "O rio Curuá abrigou as tentativas iniciais de fuga da primeira geração de escravos levados para trabalhar nos cacauais nativos e cultivados que centralizaram a vida econômica da fase colonial do Pará" (Marin e Castro, 1997: 43).

${ }^{17}$ Em 1848, quando o naturalista Alfred R. Wallace empreende sua conhecida expedição pelos rios Amazonas e Negro, menciona que o comércio local consistia na exportação de cacau, peixe (sobretudo pirarucu), cuias e gado (Wallace [1853] 1979: 96). Em Monte Alegre, as cuias eram acuradamente confeccionadas por artesãos que davam um acabamento único à peça (ibid.: 96).
} 
ocupado pelo branco nas terras devolutas, discriminadas pelo governo imperial, em cumprimento à Lei de Terras de 1850. Esse instrumento legal continha dispositivos em matéria de acesso à terra por compra e para projetos de colonização nas Províncias (ibid:: 56).

No escopo da legislação, as margens do rio Trombetas "foram declaradas como referências na identificação e localização de imóveis rurais", com registro cartorial das terras transacionadas baseado num decreto de 1865 . Os titulares das terras, ricas em castanha e madeira,

passavam a ser comerciantes - antigos e novos -, sitiantes e fazendeiros das cidades próximas. $\mathrm{O}$ movimento contribuiria à alienação de territórios ocupados e explorados economicamente pelos negros que desciam lentamente das cachoeiras (ibid.: 56).

Assim sendo, Marin e Castro opinam que a divisão relativa entre as áreas acima das cachoeiras do Trombetas, onde se situavam os escravos fugidos, e abaixo, onde se encontrava “o mundo do branco e do senhor", é progressivamente alterada (ibid.: 56). Fatores como o barco a vapor e a livre navegação do Amazonas, a exploração de castanha e a proposta de colonização compassaram um ritmo crescente de intromissão e aproximação com os grupos negros (ibid:: 56). Intromissão precisada pela instrução à perseguição aos mocambos, considerados "ameaças à propriedade" (ibid.: 57). Mais decisiva intrusão, porém, foi aquela das relações econômicas comandadas, justamente, pelos grandes comerciantes da área:

Entretanto, foi a dinâmica das relações econômicas que contribuiu de forma decisiva para o envolvimento desses trabalhadores em relações de patronagem que ordenam a nova teia de relacionamento com a sociedade escravista e, de forma mais aprumada, com a organização econômica e política paraense do pós-abolição. Os antigos e novos comerciantes e/ou proprietários presidem, nesse tempo, o avanço sobre o território negro, conduzindo a integração, profundamente desigual, do grupo na economia regional (ibid.: 57).

Chegamos a um ponto crucial. Sugerimos que, se antes o mocambo representa uma forma opositiva e de resistência, porém parte, da territorialização colonial do capital (Toledo, 2008), as relações vão se modificando a ponto de o mocambo integrar uma dinâmica regional (Oliveira, 2008). Os primeiros ensaios de uma legislação fundiária, com objetivo de regular o acesso e usufruto dos meios de produção, tal como o desenvolvimento de relações comerciais alicerçadas na patronagem, no contexto de crise do escravismo, determinam a reprodução de relações particulares de produção, com base no poder possuído pelo comerciante na 
mobilização do trabalho (Gaudemar, 1977) de seus subordinados. A região, pois, designa uma formação na qual a força de trabalho se repõe internamente, dada a ausência de superpopulação relativa que pudesse ser capitaneada nacionalmente. A nosso ver, o excerto acima evidencia que os projetos de colonização, apesar de orientados para a formação de força de trabalho, tendem a corroborar no estabelecimento de relações regionalmente reproduzidas. De modo que a escala regional é momento da territorialização do Estado na imposição da violência necessária ao controle do trabalho na produção de mercadorias (cf. Heidemann et. alli, 2014). Por isso, os laços existentes entre os comerciantes de Alenquer e os Pretos do Pacoval estão situados numa conjectura.

Na expedição de Muniz aos castanhais à montante do Curuá e do Mamiá, também são descritas as condições de apropriação fundiária e de produção da castanha. A exploração é endossada na posse da terra pelos donos dos castanhais, faltando, na visão do inspetor, medidas de fiscalização (Muniz, 1922: 19). Somente após o decreto estadual n. 1686, de abril de 1910, passaria o governo paraense a regularizar a venda de terras devolutas de castanhais, no caso equiparando-as juridicamente a "terrenos de indústria extrativa" (ibid.: 20). Lançado o decreto, logo surgiriam petições de compra de terras de castanhais mais acessíveis aos rios.

Dado que sua tarefa consiste na verificação das petições, o autor enumera recorrentes adulterações nas medidas dos terrenos. Assim, por exemplo, o tenente-coronel Alfredo de Sousa Corrêa requeria por compra os castanhais em terras devolutas à margem direita do Curuá, entre o igarapé Macupixizinho e o estirão do Felinto. A dimensão declarada era de 3 mil metros de frente, com 3,5 mil ha de área, enquanto em vez disso, constata a inspeção, a frente do terreno se estendia por $22 \mathrm{~km}$. A petição fora processada, porém abandonada (ibid.: 21). Outro requerente era o major João Rodrigues Souto, que reivindicava 500 ha de terra, com $2 \mathrm{~km}$ de frente, deixando de declarar outros 11(ibid.: 22). Ao total, apenas cinco pedidos de compra foram apresentados à Secretaria de Obras Públicas, todos processados, mesmo que apenas um não contasse com dimensões fraudadas (ibid.: 23). Todas as requisições foram abandonadas por seus solicitantes, por morte ou falta de pagamento de emolumentos. Só em 1919 surgiriam novas solicitações, numa soma de 28 - entre as quais, duas de Santos Amaral, caducadas a seu pedido (ibid.: 24).

Tanto a falsificação das medidas quanto o abandono das petições têm algo a dizer a respeito das relações com a terra naquele contexto. Os embustes são vantajosos para seus praticantes, talvez não exatamente pela extensão de terras que, ao serem vendidas, retornam como ganhos monetários. O objeto da riqueza para o proprietário, digamos, parece ser mais as castanheiras, distantes umas das outras - daí se pleiteando grandes domínios fundiários. Até 
segunda ordem, não tem nexo para o requerente pagar pela terra da qual já desfruta. Portanto, sublinhamos que a salvaguarda da dominação exercida pelos comerciantes não reside na propriedade fundiária stricto sensu, pois só ocasionalmente a terra é mercadoria transacionada por sua capacidade de produzir valor, isto é, de nela ser territorializado trabalho; a venda não é determinante da reprodução regional. Igualmente, seria imprudente ignorar as condições sob as quais um produtor pode se apossar da base fundiária: a questão é que, se política e economia estão fusionadas na região, é esta a circunstância do poder do comerciante (cf. Oliveira, 2008). E prescrevemos a extensão dessa compreensão aos fatores de produção, de sorte que terra, trabalho e capital aparecem fusionados numa visão retrospectiva do processo.

Quando se presta a analisar a gênese da renda fundiária, Marx (1. III t. II, 1986, cap. XLVII) mostra como no produto do trabalho camponês renda da terra, assalariamento e lucro/ juro capitalista são fatores indiscerníveis (poderia dizer que estão fusionados?). A passagem da tributação desse trabalho na forma de renda em trabalho para renda em produto e, por fim, em dinheiro, engendra a separação dos fatores colocados, representando uma interpretação alternativa da acumulação primitiva de capital. Para sermos conceitualmente mais rigorosos, a reprodução global capitalista, ao fim, autonomiza tais formas como fontes aparentemente independentes de rendimentos, segundo o capítulo da fórmula trinitária (ibid., cap. XLVIII). Terra, trabalho e capital ostentam uma aparência de autonomia, ossificada em diferentes personificações ao mistificar um fundamento comum. À personificação da terra, isto é, ao proprietário fundiário, esta lhe seria responsável pela geração de renda tributada num aluguel de terreno, ao passo que para o trabalhador o salário embolsado seria resultado natural de seu esforço, bem como para o capitalista a mera propriedade do capital lhe renderia retornos acrescidos de juros. A autonomização obnubila a relação existente na exploração do trabalho como origem da mais-valia. Se, no contexto que pesquisamos, a exploração não resulta na produção de valor no assalariamento, a dominação deve garantir a extorsão de excedente, por assim dizer, por outros meios. Todavia, o projeto de modernização centralizado no Estado in fieri presume a autonomização das categorias do capital para a produção de mais-valia, à revelia de relações de trabalho organizadas anteriormente.

Nos trechos finais de sua expedição, Muniz (1922) encontra barracas ocasionalmente queimadas ou, quando próximas a castanhais, abandonadas, de taipa e às vezes cobertas de palha. Tomando a descrição da paisagem, distinguimos moradias com roçados e construções mais sofisticadas servindo de comércio, em funcionamento sobretudo no período de safra, e abastecido por comerciantes citadinos, para quem se paga por uma licença: 
Há vários commerciantes que possuem interesses tanto no rio Curuá, como no Mamiá, que pagam uma licença permanente para poderem comerciar com gêneros de diversas espécies, sem embaraço algum, em qualquer época do anno, principalmente durante as safras de castanha, e tendo mais o interesse de assegurarem-se pontos de commercio que julgam favoráveis para os seus negócios.

Nesse sentido os commerciantes fortes da cidade mantem uma espécie de aviados permanentes que pagam impostos no próprio nome (ibid.: 29).

O comércio opera mediante adiantamento de mercadorias pagas com castanhas, formando uma cadeia vertical de fornecedores e produtores. Lembrando: no Curuá, Antonio Vallinoto e Santos Amaral são as maiores firmas. Para expandirem sua rede de negócios, contam com uma série de aviados (ibid.: 39), configurando um complexo designado como aviamento. Muniz, à sua maneira, demonstra como são as relações de trabalho que repõem tal complexo nos castanhais:

[...] pude tirar a conclusão de que ninguém é coagido a ficar ou deixar o logar, a trabalhar com A. Vallinoto \& Cia ou com José Antônio Ferreira, ou ainda com Francisco Miléo.

Tambem ninguém alega direitos de ocupação de terreno: antes, reconhecem todos que estão em terras que lhes não pertencem.

A falta de braços durante as safras faz com que os proprietários e posseiros de terras no rio Curuá facilitem a permanência nas suas terras, permittindo a construccção de barracas e a feitura de roçados, únicos meios de prender o trabalhador ao solo e o aproveitamento de seu braço diretamente no período das safras da castanha (ibid.: 45).

O trabalho não implica nem obrigação do extrator em se restringir a seu local de trabalho nem submissão a um comerciante em específico. Malgrado o fragmento sugira o domínio da terra pelo comerciante, convém, dado o que discutimos antes, deixarmos em aberto se não se trataria, o caso, de terras devolutas sob tutela do Estado. De todo modo, a posse é cedida ao produtor haja vista a necessidade de se empregar força de trabalho durante a safra. Por esse caminho interpretativo, a troca assume, de alguma forma, caráter de proporcionalidade entre os agentes do processo? Se sim, o ponto é o que subjaz à igualdade.

A clássica pesquisa de Roberto Santos - História econômica da Amazônia (18001920) - relaciona o aviamento à produção do excedente na economia gomífera (Santos, 1980, cap. 6), definindo o regime como "forma da economia amazônica típica" (ibid.: 158). Ou 
ainda, como instituição formada do contato da sociedade amazônica com o "sistema altamente monetizado do capitalismo industrial europeu" (ibid.: 155). Para o interlocutor, o aviamento tende a se repetir em toda área onde prevalecem recursos naturais de base espacial ampla e de difícil acesso, com "atraso das técnicas de produção", baixo índice de participação do dinheiro nas trocas e presença de lideranças mercantis locais aliadas ao mercado monetizado, sendo tais relações ativadas pela demanda externa de produtos dessa área (ibid.: 155). As relações teriam gênese em esboços de concessão de crédito informal desde o período colonial, e são enquadradas como embrião do mecanismo imperante no auge da exploração da borracha.

Naquela época [no período colonial], o negociante sediado em Belém supria de mantimentos a empresa coletora das "drogas do sertão", para receber em pagamento, ao fim da expedição, o produto físico recolhido. Essa modalidade de financiamento ficou conhecida com o nome de aviamento, uma espécie de crédito sem dinheiro (ibid:: 156).

Eis uma elucidação sintética do aviamento, que remete a uma relação não alicerçada no dinheiro, o que não significa a ausência absoluta deste no esquema. Nas lentes de Santos, a relação é designada pela demanda externa e realizada com a coordenação entre representantes do capital internacional e comerciantes locais, surgindo da dinâmica do mercado mundial. Coordenação, em seus termos, que atua "no sentido de reunirem mais braços e apoio logístico para organizar e ampliar em maior escala as empresas de coleta", inclusive ditando a expansão territorial da economia gomífera (ibid.: 157). Ao mesmo tempo que o sistema é balizado na subministração de crédito em dinheiro para firmas locais, o equivalente geral é deveras recusado tanto pela população cabocla quanto pelos comerciantes. O dinheiro se restringiria quase que somente à função de medida comparativa subordinada ao escambo, que preservaria vínculos de dependência entre o freguês e seu aviador (ibid.: 157). O crédito disponibilizado disfarçaria a usura e a exploração, até para além da consciência dos agentes, mesmo quando prescindindo de "caráter policialesco""18 (ibid.: 156-7). O aviamento, na sua

\footnotetext{
${ }^{18}$ Como ocorria em outras situações; afinal, a dominação assume vieses diversos. O antropólogo francês C. Geffray (2007: 56 e ss.) mostra como nos castanhais próximos a Marabá, ainda no começo da década de 1990, a violência explícita do patrão aterroriza os aviados, que não poderiam nem dever demais nem saldar seus débitos, com risco de serem mortos. Em outra publicação, o mesmo autor explana que nas "relações de dependência pessoal" que intitula como paternalismo - uma forma peculiar a áreas longínquas da floresta amazônica (Geffray, 1996: 153) -, vigora um sentimento de reciprocidade a legitimar tal relação, mas que esconde a desigualdade que aprofunda as obrigações do explorado (ibid.: 157). O patrão é visto como protetor e distribuidor paternal, com seu carisma perpetuado pelas relações de apadrinhamento, enquanto o produtor, apesar de dono de sua capacidade de trabalho, é submetido através de um sistema de endividamento cuja quitação é vista como favor e obrigação para com o patrão (ibid.: 157).
} 
apresentação mais elementar, configura um regime de fornecimento de mercadorias a crédito, acomodado numa cadeia vertical de provisão (ibid.: 159):

Aviar, na Amazônia, significa fornecer mercadorias a crédito. O "aviador" de nível mais baixo fornecia ao extrator certa quantidade de bens de consumo e alguns instrumentos de trabalho, eventualmente pequena quantidade de dinheiro. Em pagamento, recebia a produção extrativa. Os preços dos bens eram fixados pelo "aviador", o qual acrescentava ao valor das utilidades fornecidas juros normais e mais uma margem apreciável de ganho, a título do que se poderia chamar "juros extras". Esse "aviador", por seu turno, era "aviado" por outro e também pagava "juros extras" apreciavelmente altos.

Pois então, de que dinheiro se trata e como ele intermedia as relações fundantes do aviamento? A princípio, poderíamos objetar a presença in fieri do dinheiro num contexto de formação das categorias do capital. O dinheiro não opera como equivalente geral, ou seja, ele não é uma mercadoria autonomizada pela qual todas as demais são igualadas (Marx, 1. I t. I, 1985, cap. III). Para sermos mais precisos, o dinheiro não é o meio exclusivo da socialização dos agentes que repõem o sistema. Nem tudo vale como mercadoria, na análise de Marx como representante de trabalho humano em geral, e nem tudo é socializado segundo determinado quantum calculado em moeda (ibid., cap. I). Visto isso, focamos em como a produção de mercadorias ativada num contexto extrarregional organiza o aviamento, como relação na qual não é exatamente o valor o que media as relações sociais. As relações não são estipuladas pela medição de tempo de trabalho socialmente necessário - tempo abstrato - na produção de uma mercadoria qualquer e na equiparação com outras pela redução a uma substância social comum (ibid.: 47) ${ }^{19}$. O movimento, porém, é de substancialização, isto é, de imposição do valor como forma de comando da reprodução e da autonomização do dinheiro como equivalente. Concomitantemente, o aviamento opera mobilizando trabalho, por expedientes particulares de violência extraeconômica que passam pelo escambo, na produção de mercadorias.

Por outro lado, o dinheiro intermedia relações no mercado extrarregional e, ao menos parcialmente, tem efeitos na organização do aviamento. É possível que, inicialmente, ele opere como medida na estipulação dos preços cobrados no comércio e pagos pela produção

\footnotetext{
19 “Consideremos agora o resíduo dos produtos do trabalho [nas mercadorias]. Não restou deles a não ser a mesma objetividade fantasmagórica, uma simples gelatina de trabalho humano indiferenciado, isto é, do dispêndio de força de trabalho humano, sem consideração pela forma como foi despendida. $O$ que essas coisas ainda representam é apenas que em sua produção foi despendida força de trabalho humano, foi acumulado trabalho humano. Como cristalizações dessa substância social comum a todas elas, são elas valores - valores mercantis" (Marx, I. I t. I, 1985: 47, grifos nossos, D.L.).
} 
extrativista, balizando o escambo. Por isso o disfarce da dominação e dos ganhos por parte do comerciante, provindos da diferença perniciosa de preços. Mas, dialogando com o argumento de Santos, a dominação é inconsciente; ela se objetiva em relação a seus agentes. O enunciado é importante, a despeito de uma redução utilitarista que, por ventura, pensaria no apanágio da classe dominante como fruto de cálculo econômico racional no acionamento da violência para benefício pessoal ${ }^{20}$. A dominação nos parece impessoal na medida em que, com o perdão do trocadilho, os sujeitos se sujeitam como personas da produção abstrata de riqueza social.

A produção de riqueza no aviamento é, como relação particular de produção, tomada por Santos pela extração do excedente, isto é, na "diferença entre o valor que internamente se produzia e o de que a população consumia" (Santos, 1980: 155). O produto da subtração, colocamos, deve ser o necessário para a reposição regional de força de trabalho, também pautada por práticas que não são estipuladas pela mercadoria.

Ponderação a parte, o autor lista três parcelas motivadoras da acumulação de capital na economia gomífera (ibid.: 162). A primeira parcela provém da extorsão do seringueiro (ou mais, do produtor), extraindo-lhe o máximo de rendimento com o mínimo de pagamento, com o saldo compartilhado entre as cadeias superiores do esquema: aviadores, governo, centros industriais, etc. A segunda fonte consiste no "lucro empresarial" do aviador, decorrente de sua capacidade pessoal de organização, enquanto a última resulta de inversões de capital fixo e de giro enviados por não residentes na região. A partilha do excedente depende do contexto, mas sempre um fragmento deve permanecer na área, na forma de impostos e de imobilizações que repõem os pressupostos da produção (ibid.: 162).

O problema posto é de como o patrão embolsa o excedente e como o aviamento viabiliza a expansão da produção extrativa. Antes de tudo, a espoliação do seringueiro suporta

\footnotetext{
${ }^{20}$ A exploração de balata, sapotácea encontrada em grande parte na porção compreendida entre Alenquer e Almeirim, movimenta expedições na área entre as décadas de 1940 a 1970, destinadas à exportação de látex, beneficiado nos EUA para a produção de bolas de golfe e materiais odontológicos. A produção também é organizada com base no aviamento. A antropóloga Luciana G. de Carvalho (2013) salienta a reprodução do aviamento nos balatais conforme uma cadeia de interdependência amarrada pela produção, na qual o balateiro é o "elo mais fraco". No outro extremo do conjunto, por sua vez, temos o patrão: "Enfim, além da provisão material, os patrões - categoria ampla em que cabem todos os sujeitos dos quais os balateiros dependem e aos quais respeitam como autoridades - aliciam os extrativistas com bebidas, festas, foguetes e socorros em situações emergenciais como casos de doenças" (ibid.: 389). Dessa maneira, a autora reduz a dominação à vontade do dominador e a certa passividade do dominado, sem pensar em por que a dominação ocorre, como forma necessária à reprodução de uma estrutura objetivada e inconsciente. Em Dominação sem sujeito, R. Kurz ([1993] 2010, item I) critica as concepções que reduzem a dominação a um cálculo utilitário subjetivista da classe dominante, situando tal individualismo num contexto social: "na modernidade, o que vem à luz paradoxalmente como individualismo não constitui, na realidade, nada próprio ao indivíduo, mas algo que dele se assenhora. Também os dominadores são dominados, haja vista que nunca dominam efetivamente por necessidade própria ou por mera satisfação, senão que em prol de algo que se acha pura e simplesmente para além deles mesmos" (ibid.: 216).
} 
a riqueza do seringalista, composta sobremaneira por capital de giro devido ao baixo desenvolvimento técnico da produção vertido em capital fixo (ibid.: 163). Situação que, se implica na dilatação da acumulação, demanda um número crescente de trabalhadores para aumentar a massa de excedente produzido. Nesse caso, o excedente se origina de três fontes, nomeadamente: da diferença de preço da borracha comprada e vendida pelo aviador, da transferência para o produtor dos encargos que caberiam ao seringalista (como o "custeio" dos instrumentos) e, enfim, da aferição de "lucros" e "juros" arrancados ao extrator na venda de bens de consumo no comércio (ibid.: 163). Para o autor, a transferência dos "custos" com os "bens de produção" e a margem extraída da venda dos artigos compreendem os "juros extras" confiscados pelo seringalista (ibid.: 163).

Acontece que, ao expor a relação de excedente nos termos do custeio, do lucro e do juro, nosso interlocutor pode dissimular distinções de contexto, aplicando inadvertidamente categorias da economia política referentes à reprodução capitalista ampliada: é como se o aviador fosse um capitalista industrial. Ao contrário disso, objetamos que o aviamento é uma relação na qual as categorias capitalistas não são autônomas em relação ao trabalho, nem a classe dominante cerceia o trabalhador de suas condições de produção. E não é estranho que a dissimulação rebatida anseie à modernização. Tanto que o interesse, especialmente engajado no que o autor chama de "resistência à monetização", se extrai da indagação seguinte: "por que a sociedade que estabeleceu contato com o capitalismo não se monetizou rapidamente e não se integrou completamente ao mercado?" (ibid.: 171). A reposta passa pela resistência das lideranças mercantis locais, que pretendiam preservar sua posição privilegiada nas trocas, mas culmina em disparates como o "peso das tradições do escambo" e "fatores culturais". Seriam fatores a "ética do aviamento", o "baixo nível intelectual dos produtores" e o "atraso das técnicas de produção" (ibid.: 171). Ao fim, "mesmo sem existir mercado, aquelas áreas atuam e produzem. O aviamento substitui o mercado" (ibid.: 171, sublinhado nosso, D.L.).

Com isso, Santos tende a abandonar a atenção a qualquer particularidade, concebendo o mercado a partir dum tipo-ideal, e o aviamento como substituição deste, ao não se encaixar nos pressupostos teóricos almejados. Ora, o "peso das tradições" e os "fatores culturais" não existem sem condições sociais que os produza. A justificativa do "baixo nível intelectual dos produtores" abstrai as estratégias das quais estes se aproveitavam para se reproduzirem no regime $^{21}$, tal como a máxima do "atraso" ignora o capital como forma da sociedade que se

\footnotetext{
${ }^{21}$ Na obra A borracha na Amazônia, da brasilianista Barbara Weinstein (1993), há uma descrição minuciosa das relações de produção que subsistem à economia gomífera, mas cujo exame excede nossa pretensão expositiva. Nos seringais, era comum que o extrator vendesse, mais ou menos secretamente e a dinheiro, borracha para
} 
reproduz a partir de diferentes contextos. Apesar disso, o próprio "atraso" não é falso ao cimentar uma base de intervenção modernizadora, na qual o aviamento parece um entrave a ser superado $^{22}$. Diante dessas alegações, propomos uma reformulação da pergunta posta pelo autor: não é que a sociedade amazônica estabeleceu contato com o capitalismo, senão que ela surge da divisão territorial do trabalho na constituição do capital, sendo a supramencionada “integração ao mercado" representada pela monetização.

Manifestamente, essas relações são modificadas de acordo com a área e o produto explorado. Nos castanhais, como vimos, a coação não é exercida no intuito de interditar ao trabalhador o usufruto da terra e de bens pretéritos da natureza. A dominação se sustenta em outro registro. Mas daí, o que leva o castanheiro a se submeter ao aviamento? Uma primeira apreciação da pergunta pode nos remeter à concessão da terra; outra avaliação diz respeito ao que se pode gozar no sistema de escambo - produtos e favores? (cf. nota 18). Em ambos os pareceres, as "relações de dependência pessoal" que "fecham" a região (Oliveira, 2008), digamos assim, são em certo grau veladas. Em R. Santos, a espoliação do produtor é fonte da riqueza do aviador na medida em que este: a) estipula os preços pagos pela produção e cobrados no comércio; b) transfere custos com meios de produção. Daí a produção e ampliação do excedente, diante do que formulamos o seguinte: a formação do excedente é precisamente o pressuposto da reprodução regional; a produção de excedente regional é o desígnio que funda o aviamento. Além do mais, temos que essa elaboração retira da noção de região a aparência de autonomia face à sociabilidade da mercadoria.

Com uma última passagem pelo relatório dos Castanhaes, ressaltemos a notoriedade do conflito entre região e Estado. Além das ameaças sofridas pelo inspetor, é sintomático o receio dos donos de terrenos de perderem a hegemonia na região, em favor de "estrangeiros" supostamente apoiados pelo Estado. Desse modo, uma reclamação redigida pelo comerciante José A. Ferreira é endereçada a Muniz (1922: 36), solicitando "que não se entreguem os ricos castanhaes de Alemquer a estrangeiros". A aflição, que reportaria à "abertura" da região (cf.

\footnotetext{
regatões, ou então misturasse ao látex impurezas, para que produzisse mais utilizando uma quantidade menor de goma (ibid.: 36-7). Sem contar que o seringueiro, a variar de contexto, poderia se aproveitar do patrão para acessar mercadorias que, de outra forma, não conseguiria, contraindo a dívida e depois fugindo (ibid.: 37). Igualmente, defendemos que o compadrio, se por um lado esconde a dominação do patrão, é socialmente aceito porque o subordinado espera algo disso.

${ }^{22}$ No mais, a Crítica à razão dualista de Chico de Oliveira (2013) salienta o caráter ético desse pensamentobase do período populista, e mostra como o que se tem por "primitivo" é parte funcional da formação histórico-econômica nacional. Assim, há uma crítica à oposição formal atrasado-moderno imprimindo o real da dialética à reposição dessa contradição. Com isso, reiteramos que em vez de falso, o dualismo, emprestando os termos de Marx (I. I t. I, 1985: 71), é uma abstração real, isto é, que se efetiva, do desenvolvimento capitalista em suas escalas global, nacional e regional.
} 
Oliveira, 2008: 151), não é inconveniente com as relações reproduzidas se destacamos que, para aquelas personas, a regularização fundiária, no mínimo, causa estranhamento. Dada a possibilidade da posse fundiária na fronteira, a noção de terra devoluta parece sem propósito:

Aquelle cidadão, em cuja casa de residência estive, declarou-me que as terras devolutas do Estado são do povo e que não é necessário regularisar a ocupação das mesmas, porque acabada a matta de um terreno, vende-se a casa e procura-se outro para viver (Muniz, 1922: 49).

Claramente, aqui, "terra" não desempenha a função de mercadoria transacionada com base em sua capacidade de gerar renda e calculada em dinheiro. O que é vendido, no fragmento, não é o terreno, senão a casa. Com tudo isso, sustentamos que a monetização e a "resistência" a seu imperativo podem consistir numa primeira aproximação das relações de produção que dão um caráter à fronteira e ensejam transformações. A disputa da região com o Estado convém, pois, se apontamos em que sentido se preside a mobilização do trabalho (Gaudemar, 1977) na área.

\subsection{Os projetos de colonização da primeira metade do século $X X$}

Agora, a questão é como com o passar do tempo se realiza a pretensão de assentar o colono como trabalhador.

A dissertação de Myriam de Oliveira (2002), defendida junto à UFPA, analisa o "papel e a viabilidade da produção familiar" nas transformações do "sistema agrário" da margem esquerda do Baixo Amazonas (ibid.: 15-6) ${ }^{23}$. No texto, a região é um dado fornecido pelo IBGE, segmentada em zonas nas quais se aplica um modelo de gestão agropecuária (ibid.: 25). Assim, desenvolvendo o que chama de "zoneamento histórico", a autora aponta uma lenta transformação no "sistema agrário" da área desde o fim do século XIX, oriunda sobretudo de programas de colonização e da "ocupação espontânea" da terra por nordestinos (ibid.: 42). Migrantes trazidos pelas políticas de povoamento vinham incrementar a produção agrícola de terra firme, preenchendo a "lacuna do mercado local" deixada pelo êxodo para os seringais. Logo, os "estabelecimentos de terra firme deixaram de ser unicamente voltados para subsistência e se inseriram no mercado", mormente na produção de alimentos (ibid.: 43).

Como resultante, culturas antes pouco estimuladas foram desenvolvidas, e "tornaramse importantes geradoras de renda para as famílias", com destaque para o milho, o algodão e o

\footnotetext{
${ }^{23}$ "Sistema agrário" é um conceito discutido e empregado por Oliveira que se refere à espacialização de uma estrutura complexa de elementos naturais, socioeconômicos e técnicos na pesquisa sobre o agrário (Oliveira, 2002: 17-21).
} 
tabaco (ibid.: 43). Parece-nos que a "inserção no mercado" e o critério de "geração de renda" empregado pela autora tanto denota que os cultivos mencionados são basicamente voltados para o mercado quanto atesta a aspiração à produção agrícola para comercialização. $\mathrm{O}$ programa de colonização reverbera na modificação, ainda que lenta, lembremos, do "sistema agrário" da área, com especial consequência para Monte Alegre (ibid.: 43):

Monte Alegre constituiu-se um caso particular no Baixo Amazonas devido ao fato de ser colonizado a partir de programas e projetos implementados pelo governo [...] Também por conta dessas iniciativas foram criadas as colônias agrícolas de Itauajuri e Igarapé-açu, em 1894, para a fixação de migrantes espanhóis, e de Açaizal e Dois Galhos, em 1930, para migrantes japoneses [...] Nessa época, ao longo do processo de penetração nas áreas de terra firme, a ocupação espontânea por migrantes nordestinos e famílias locais se fez até meados do século XX, para depois se encaixar no padrão de colonização dirigida, com a criação do Núcleo Colonial Inglês de Souza, em 1928.

Ou seja: entre as décadas de 20 e 30 são aplicadas novas medidas de colonização no município, envolvendo populações já assentadas numa área ocupada mais ampla que no encerramento do século precedente, além de se fundarem projetos que incluem os recémchegados japoneses. Só que vale uma correção do excerto: a gleba Inglês de Souza data de outubro de $1927^{24}$.

Catorze anos depois, o governo Vargas funda Colônias Agrícolas Nacionais (CANs) e, em 1943 os domínios da Inglês de Souza são incorporados à Colônia Agrícola Nacional do Pará (Canp) $)^{25}$, a cerca de $20 \mathrm{~km}$ a noroeste da sede de Monte Alegre. O Decreto-lei 3059/41, que dispõe da criação das CANs, discrimina em seu Artigo $1^{\circ}$ :

receber e fixar, como proprietários rurais, cidadãos brasileiros reconhecidamente pobres que revelem aptidão para os trabalhos agrícolas e, excepcionalmente, agricultores qualificados estrangeiros.

\footnotetext{
${ }^{24}$ O decreto no 17952, de 18 de outubro de 1927, declara em artigo único: "Fica creado no Municipio de Monte Alegre, no Estado do Pará, o Centro Agricola 'Inglez de Souza', revogadas as disposições em contrario". Disponível em: <www2.camara.leg.br/legin/fed/decret/1920-1929/decreto-17952-18-outubro-1927-501376-p ublicacaooriginal-1-pe.html>. Acesso em: 20 de julho de 2018.

${ }^{25}$ O decreto-lei 3059/41 dispõe sobre a criação das Colônias Agrícolas Nacionais. Disponível em: <www2.camar a.leg.br/legin/fed/declei/1940-1949/decreto-lei-3059-14-fevereiro-1941-413001-publicacaooriginal-1-pe.html> Acesso em: 20 de julho de 2018. Já no decreto-lei 5240/43, encontramos: “Art. $1^{\circ}$ Ficam encorporadas à Colônia Agrícola Nacional do Pará, da Divisão de Terras e Colonização do Ministério da Agricultura, as terras a que se refere o decreto-lei n. 4.179 de 24 de novembro de 1942, baixado pelo Governo do Estado do Pará. Art. $2^{\circ}$ O Núcleo Colonial 'Inglês de Sousa', situado na mesma região, passa ao regime do decreto-lei n. 3.059, de 14 de fevereiro de 1941". Disponível em: <www2.camara.leg.br/legin/fed/declei/1940-1949/decreto-lei-5240-10fevereiro-1943-415369-publicacaooriginal-1-pe.html>. Acesso em: 20 de julho de 2018.
} 
A lei pode ser lida como revelando uma política nacionalista, na formação de uma massa de trabalhadores agrícolas como recurso do Estado; como vimos - e nossa pesquisa empírica ratifica -, esse contingente é composto majoritariamente por nordestinos pobres. $\mathrm{O}$ termo "aptidão" também pode ser lido da perspectiva do disciplinamento da população: conforme uma deliberação oficial se decide quem é ou não agricultor e deve receber um lote. Para isso, lança-se mão de um conjunto de exigências comportamentais e médico-sanitárias que, caso não cumprido, prevê a despossessão sem indenização por eventuais benfeitorias.

Nos demais artigos, observamos que o governo é o responsável pelo custeamento da fundação e manutenção das colônias agrícolas. Estava programada, ao menos para o ano de instalação dos colonos no local, a remuneração, em salário ou por empreita, por trabalhos de formação dos núcleos coloniais, bem como assistência médica e farmacêutica, empréstimo de máquinas e instrumentos agrícolas e transporte até a sede do projeto. Esses núcleos deveriam ser erguidos sobre uma situação com recursos hídricos que permitissem obras de irrigação, com condições climáticas favoráveis para a produção agrícola. Escolhido o local, os técnicos iniciariam o loteamento dos terrenos - de 25 a 50 ha, reservando-se pelo menos um quarto de sua vegetação original - e da sede, que contaria com infraestrutura educacional e postos para beneficiamento da produção agropecuária. A lei ainda previa a formação de cooperativas e dispunha sobre o sorteio de lotes agrícolas e urbanos, com emissão futura de título de propriedade, sem que se pudesse vender o terreno durante o processo de regularização. Em suma, haveria uma preocupação no estabelecimento de um modus operandi da produção que possui desdobramentos na organização dos colonos.

Outra empresa marcante do período fora a colonização japonesa, que Tatsuo Ishizu (2007), em sua dissertação, reconstitui a partir de duas grandes levas migratórias: a primeira entre as décadas de 1920 e 1930 e a última nos anos 1950 (ibid.: 116-7). Pesquisando em jornais paraenses do princípio da década de 1930, ele mostra como a antiga Colônia de Itauajuri é renomeada como Major Barata (Menejó) para homenagear ao primeiro gestor da gleba, tal como se passa a organizar os primeiros projetos colonizadores nipônicos (ibid:: 78):

Os colonos japoneses começaram a povoar terras de Monte Alegre a partir de novembro de 1929. Eles eram em número de 20 imigrantes que haviam chegado ao Pará, em setembro do mesmo ano, contratados pela Companhia Nipônica de Plantações do Brasil S.A. A colônia dos japoneses, temática que de fato nos interessa, ficava distante cerca de 35 quilômetros da sede do município e denominou-se Mulata, em virtude do igarapé do mesmo nome que existia na sede da colônia. As terras que os imigrantes japoneses da 
Companhia Nipônica ocuparam haviam sido doadas pelo governo do Estado do Pará através da Lei n. 2.746, de 13 de novembro de 1928 e ocupava uma área de 400.000 mil hectares (ibid.: 78).

A imigração, portanto, é financiada por uma empresa privada em parceria com o Estado, o que a distingue das políticas colonizadoras precedentes. No texto consta, ainda, a pretensão grandiosa do empreendimento, que esperava tornar a gleba Mulata a maior referência na fabricação de fibras de algodão do tipo mocó do planeta, além de incentivar em grande medida o cultivo e beneficiamento de tabaco (ibid.: 78-9). A Companhia Nipônica também pretendia explorar minério de ferro e madeira, escoando a produção por uma estrada de ferro que seria edificada em Prainha. Esse projeto era composto de duas etapas, sendo a primeira a de experimentação e a última de dispendioso investimento infraestrutural (ibid.: 80). Todavia,

Mulata nunca conheceu além da fase experimental. Em 1935, a empresa prevista para Monte Alegre foi abandonada na prancheta. Tudo o que havia construído ali até então foi deixado para trás, simplesmente abandonando. Não obstante entusiasmo dos primeiros anos, os projetos econômicos malograram. As experiências com o algodão não surtiram efeito positivo devido não ter conseguido produzir espécie com fibra longa. A mesma sina foi experimentada pelo tabaco (ibid:: 80).

Os argumentos são posicionados no âmbito do fracasso com os métodos de produção, se bem que, com o escrutínio da experiência de imigrantes chegados mais tardiamente a Monte Alegre, em 1931, levantemos a importância de outras justificativas. Ishizu menciona que um grupo de, talvez, 32 homens jovens e solteiros instala-se na comunidade do Limoeiro, que se desfaz em menos de quatro meses por obra de desentendimento interno. Os moradores restantes vão evadindo para outros rincões do país de maneira a, ao estourar a II Grande Guerra, sobrar apenas três, e ao fim do conflito, um imigrante (ibid.: 81). Os japoneses estariam insatisfeitos, sobretudo, com a localização do empreendimento, demasiado inóspito e afastado de Belém (ibid.: 84), de modo que o afluxo de um novo contingente para a área ainda demoraria mais oito anos, a contar do fim da guerra (cf. cap. 3.2).

O número reduzido de imigrantes seria uma primeira variável fenomênica a explicar o rápido esgotamento do projeto. Outras causas são marcadas pelo próprio autor, como o distanciamento dos mercados, por assim dizer, mais dinâmicos, e o fracasso no cultivo de algodão e fumo em grande escala, o que pode abrir uma série de breves elucubrações. A primeira consiste na dúvida acerca do desenvolvimento técnico da produção agrícola naquela 
época e local. Uma segunda ponderação diz respeito à efetividade dos estudos das condições climáticas e edafológicas, enquanto, para encerrar, restaria acessarmos, com maior riqueza de detalhes, como se desenvolviam certas relações de trabalho. Poderíamos resumir essa ordem de problemas à viabilidade de investimento de capital no contexto em questão? Nessa medida ao menos, o malogro na política de colonização japonesa não se desvia tanto das tentativas antes empreendidas. Mas a alegação de fracasso só existe em correspondência a uma concordância com possibilidades frustradas de realização do Estado.

À primeira vista, as políticas exibidas não organizaram o trabalho no sentido de consumar, como concebido, núcleos de colonização como produtores de mercadorias agrícolas. No que foi exibido, tais núcleos se reproduzem com o comando regional da força de trabalho, através da violência personificada por grandes comerciantes, que se estende para a própria forma com que o caráter da região se define. O que sugerimos é que o aviamento e o colonato, como relações particulares no contexto de formação do trabalho livre no país, por pressupor escassa circulação monetária, indica mais a reposição das dinâmicas regionais (Oliveira, 2008) do que o monopólio da coerção extraeconômica ao trabalho pelo Estado nacional. Além do mais, é preciso interpelar em que medida as funções estatais são financiadas, assentes em sua dependência de dinheiro. Mas nem por isso, olhando retrospectivamente, a região deixa de exprimir um momento da territorialização do Estado. A rigor, o tema ultrapassa a avaliação da efetividade dos planos de colonização e discute com as condições em que o dinheiro aparece como o nexus rerum da sociabilidade moderna. A relação entre dinheiro e Estado é apresentada com um fundamento comum, e será amiúde retomada. Uma abordagem diferente remete à nossa própria pesquisa empírica, que sinaliza transformações na relação entre região e Estado, monetarização e imposição da terra e do trabalho como mercadorias na fronteira. O percurso é o discutido nos próximos dois capítulos, nos quais é importante chamar a atenção para contradições que se realizam como passagem do tempo. 


\section{CAPÍTULO 2}

\section{A COMUNIDADE DO LIMÃO, OU: ESPONTANEIDADE E DETERMINAÇÃO}

No primeiro capítulo, apresentamos nossa pesquisa recompondo políticas territoriais, do fim do século XIX à primeira metade do século XX, estabelecidas nas porções de fronteira da margem esquerda do Baixo Amazonas. O resgate histórico se deu com a interpretação de duas obras de João de P. Muniz que versam, da perspectiva de um funcionário público, sobre planos de colonização e regularização fundiária na área. Partimos dessas fontes para derivamos uma problematização da formação do Estado no monopólio da violência necessária à produção de mercadorias. No período tratado, o Estado apresenta-se passando por medidas de regulação do acesso a terra na fronteira com o intuito de impor o controle sobre a força de trabalho, prima facie em oposição às formas regionais de coerção do produtor. Observamos particularidades nas formas de reposição do comércio na produção de um excedente regional, mas deixamos em aberto um escrutínio empírico dessas relações de produção. Posto isso, o que faremos agora é avançar para o período de constituição de uma comunidade de fronteira, para daqui retomarmos pontos apresentados no capítulo anterior de um prisma distinto.

Quem viaja de Oriximiná a Prainha percorre uma rodovia que data da ditadura civilmilitar, a PA-254. Sua construção, em linhas gerais, comporta características similares a de outras estradas programadas para a Amazônia entre as décadas de 1970 e 1980: tratava o Estado de abrir os caminhos e cercá-los de lotes agrimensados destinados à colonização, intervalados por ramais picados pelos próprios sitiantes ou pelas prefeituras. Colonização que acaba por se diferenciar da ocupação até então majoritariamente concentrada nas margens dos rios, composta sobretudo por nordestinos e seus filhos. Destacar os pormenores das diretrizes de um planejamento dedicado às questões de assentamento de famílias na área fica para mais adiante. Digamos, apenas, que beirado a esta PA germina uma pletora de agrupamentos rurais.

Entre maio e junho, bem como em novembro de 2017, estivemos na comunidade do Limão, por onde passa a PA-254, localizada a $54 \mathrm{~km}$ ao norte de Monte Alegre (Mapa 2). O grupamento não surge diretamente do planejamento territorial, embora mais tardiamente passe por ingerências de relações jurídicas e políticas que se realizam no e pelo Estado, como veremos. A primeira visita veio da oportunidade de uma carona e hospedagem, oferecidas por Itajury Kishi, engenheiro florestal filho de um imigrante japonês. Fora nessa comunidade que seu pai inicialmente se instalara, num sítio que, presentemente, é de propriedade de seu irmão Tabo, todavia aos cuidados de uma família de caseiros. 
A imagem abaixo (Fig. 1) retrata a mencionada rodovia, de chão pirraçado, na qual se conta dois postos de gasolina, algumas oficinas mecânicas, mercados, boutique e um laboratório de análises clínicas. A via é paralela a um igarapé quase seco e perpendicular a ramais onde se encontram construções em madeira e alvenaria com telhados de brasilit, havendo uma escola de educação infantil ao ensino médio, residências, posto de saúde, mercearias, uma subestação transmissora de energia elétrica e a sede da associação local. A rua, como chamam os lavradores o povoado, se estende numa configuração globular por cerca de $2 \mathrm{~km}$ em relação à estrada. Ela se contrapõe ao centro, que consiste nos terrenos, roçados com pimenta-do-reino, lavoura branca, tomate, café e árvores frutíferas ("fruteiras") e para extração de madeira. $\mathrm{O}$ que se sobressai na paisagem, todavia, são capinzais quase sempre lotados com gado, configurando um arranjo produtivo e de distribuição da terra que, segundo os moradores mais antigos, se modificou contundentemente nas últimas décadas.

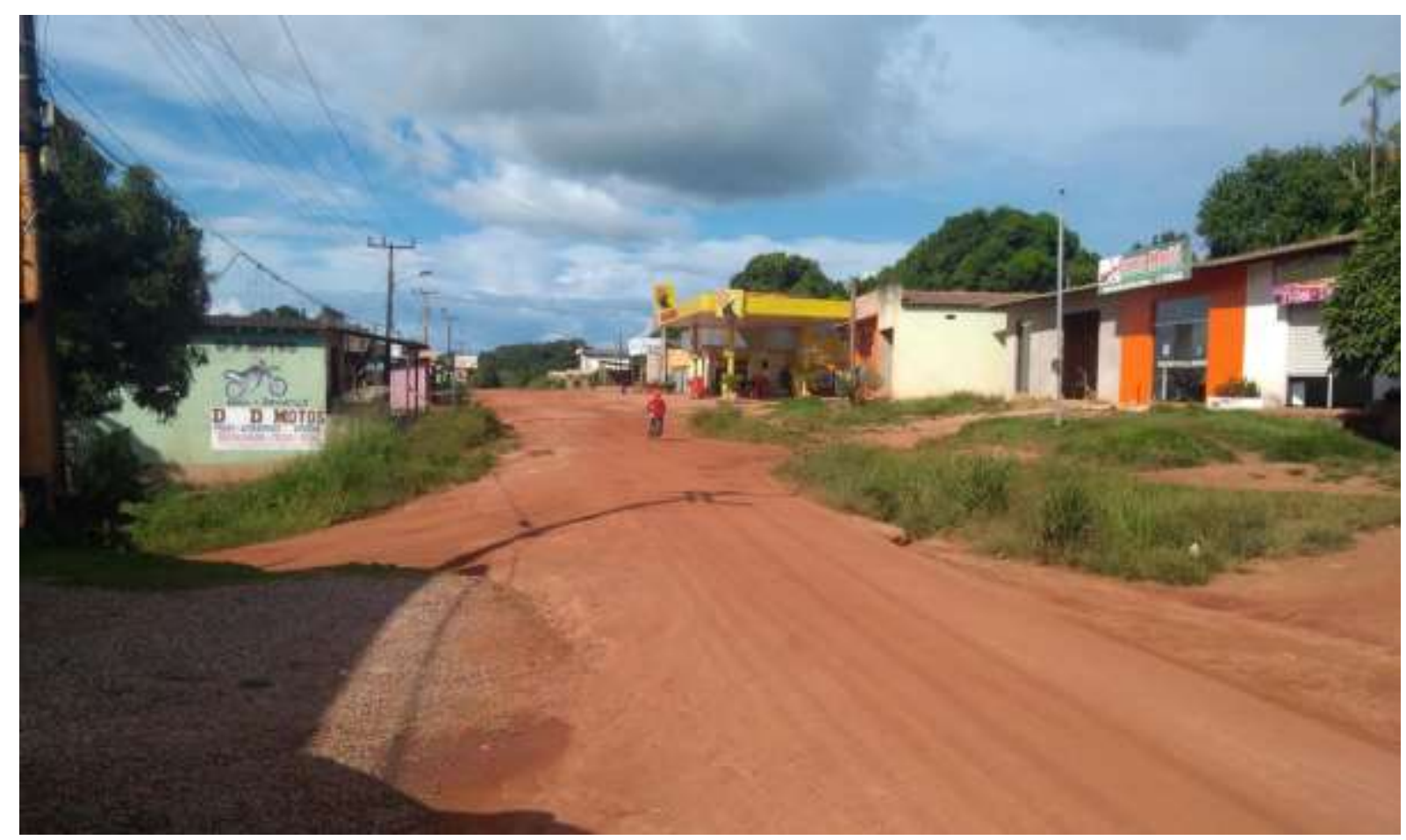

Fig. 1. A rua na comunidade do Limão, com seus estabelecimentos comerciais.

Interessa especialmente interpretar que modificações são essas, tomando de aspectos como a reprodução de gado em capinzais e a concentração fundiária, notáveis pela observação empírica, processos lógicos e históricos de constituição. O entrelaçamento dos relatos ouvidos em pesquisa de campo permite problematizar condições determinadas da reprodução social, tendo em vista, precisamente, a ocupação e uso da terra e as relações de trabalho efetivadas na 
composição da fronteira, enquanto momentos do processo de modernização de relações particulares de produção e de institucionalização do Estado. Como dissemos no primeiro capítulo, a fronteira territorializa circunstâncias nas quais lavradores acessam terras que, por não serem de monopólio de uma classe de proprietários, lhes permite a reprodução como donos de seus próprios meios de produção. Reavendo uma observação da Apresentação desta dissertação, os entrevistados personificam formas particulares e contraditórias de apropriação da terra e de relações de trabalho, personificando também permanências e transformações dessas relações através do movimento da fronteira.

As transformações na fronteira são destrinchadas no capítulo por intermédio de três perspectivas: as duas primeiras problematizando a pesquisa de campo e a última confrontando a investigação com uma visada teórica. Com base nessa conformação, a territorialização da fronteira é exposta, no cap. 2.1, da perspectiva da fundação da comunidade do Limão através do aprovisionamento de roçados por um comerciante da cidade, que também fomenta o deslocamento de famílias do nordeste do Pará para Monte Alegre. A seção, portanto, consiste num debate acerca da violência requisitada na produção de mercadorias na fronteira. As mudanças nessas relações, capitaneadas pelo comércio local, despontam na crise do monopólio da circulação na área. A segunda perspectiva (cap. 2.2) é a do surgimento e desenvolvimento da comunidade conforme a posse de terras e a aparência de espontaneidade na dilatação territorial da fronteira, tratando da subsistência dos lavradores mediante o usufruto direto dos meios de produção não produzidos pelo trabalho - sem negligenciar o mercado. Algo que culmina no começo, ainda que incipiente, de processos de compra e venda de terrenos, simultaneamente à atuação do Estado, aparentemente também preambular na área, na delimitação dos lotes e na fundação do patrimônio no Limão. Para encerrar (cap. 3.3), o debate teórico contrapõe diferentes interpretações da fronteira nas ciências sociais, dialogando os tópicos levantados pelos pesquisadores cotejados com nossa pesquisa in loco, e exibindo o que é pertinente e o que é ignorado na discussão do tema proposto.

\subsection{Fundação e relações com o comércio}

Um dos nossos entrevistados, Seu Bia, resgata aspectos relevantes da formação do Limão. Ele, como outros, relata que chegou à comunidade ainda criança, quando a floresta era derrubada para a abertura de roçados na beira do igarapé. Era passagem do verão para o “inverno" amazônico, a estação das chuvas, período das queimadas e do plantio: 
Bia: Aí nós botamo o roçado, aí quando foi em 58. No caso, em 57 teve o verão, sempre no fim do ano, né.

Pesquisador Daniel N. Leal [doravante, D.L.]: Vocês chegaram aqui no fim de 57 ?

Bia: Foi. Não deu tempo de botar o roçado, né. Em 58 deu uma chuvinha, aí no começo deu uma seca tão grande em 58, e o arroz ficou desse tamanho querendo embuchar e secou o arroz todinho. Aí chegamo na cidade, o véio que financiava as coisa pra gente, fomo lá na cidade e ele disse: "pode botar o roçado, que eu compro o arroz de vocês todinho". Comprou todo o legume.

Os terrenos, então, são de uma constituição relativamente antiga, destinados a um roçado de arroz encomendado por alguém da cidade. E mesmo com a seca de 1958, que resulta numa colheita fracassada, o demandante garante comprar a produção, como prossegue Bia:

O arroz não prestou. Aí fomo lá com ele e disse: "não, tem problema não. Pode trabalhar o outro ano, o outro ano você paga nós". "Tá bom”. Aí papai pagou o outro ano...

Percebemos que um expediente de empréstimos motiva a fundação da comunidade, mas que também deveria passar por tal processo que os lavradores chegados ao Limão tomam de posse terras que, a princípio, são "livres"26:

D.L.: Terreno era do pai do senhor mesmo?

Bia: Era. No tempo que ele chegou, chegou lá trabalhando que não tinha terra, né. A terra era devoluta, e ele não tinha terra marcada nem nada, aí eles entraram. Foi ele e o outro, era dois. Um parou na cachoeira que tem ali, e papai parou lá numa passaginha [...] O Barriga, irmão do Wilson, parou na cachoeira mesmo.

D.L.: Essas eram as duas primeiras famílias?

Bia: É. Essas foram as duas primeiras. Mas no mesmo ano, chegou um bocado, num barracão comprido, assim de palha mesmo, e fizeram uns quartinho. Aí eles se colocaram lá e foram botar o roçado. Papai tinha botado o dele, que tinha botado cedo, no verão, e ele chegava em novembro e já derrubava logo, ele, que dava tempo de botar. Muitas tarefa ${ }^{27}$. Aí esse tudo abastecia as coisa, esse velho ali da cidade.

\footnotetext{
26 "A princípio" porque a ocupação da terra, historicamente, não se dá sobre um vazio (cf. cap. 1 e a submissão do trabalho do indígena). Ela também depende, assinalemos, de um determinado nível de desenvolvimento das forças produtivas que permita ao povoamento transpor, digamos, obstáculos naturais.

${ }^{27}$ Os entrevistados nos diziam que três tarefas correspondiam a um hectare.
} 
Problematizando o relato, notamos o acesso comum a terras pelos lavradores, em partilhado acordo na delimitação de lotes, improvisando um barracão enquanto constroem suas casas e formam seus roçados. É igualmente destacável a noção de terra devoluta que guia nosso interlocutor, enquanto terra teoricamente reclamada à jurisdição do Estado, e que somente usufruída se comprada, não obstante o visto ato de posseamento ${ }^{28}$. A autonomia presente na posse de "terras sem dono", se não engajada diretamente na legislação fundiária, simultaneamente passa pelo abastecimento familiar com gêneros provenientes da cidade.

Os dois excertos exibidos - por sinal, contínuos na entrevista - destacam momentos de um mesmo processo, que motiva a contradição entre, por um lado, a espontaneidade na ocupação de "terras livres" e na reprodução familiar e, por outro, a reprodução de um sistema de empréstimos de bens não produzidos pelas famílias para a satisfação de suas necessidades - sejam elas provenientes “do estômago ou da fantasia” (Marx, 1. I t. I, 1985: 45) -, suportada por um armazém da cidade. O acesso a terra é livre, porém mediado pela necessidade de aprovisionamento que salvaguarda a formação do roçado. Mediante a reprodução da presente contradição é que expomos o desenvolvimento das relações de fronteira nessa comunidade.

Parte considerável, senão todo o conjunto, de nossos interlocutores dedicava-se, naquela época, à lavoura branca, ou seja, à cultura reposta anualmente, de arroz, milho, feijão e mandioca, destinada à subsistência e à venda no comércio. Também desfrutavam de caça, extrativismo vegetal e pesca, apropriando-se das condições preexistentes nas terras ocupadas. A banha dos animais criados era aproveitada para refogar e fritar alimentos, bem como, ocasionalmente, para produzir sabão. A lenha era queimada para a preparação das refeições e, de algum modo, para iluminar o ambiente, assim como parte da madeira derrubada para a formação do roçado era aproveitada na construção dos móveis (basicamente, uma mesa e bancos) e das casas, cobertas com palha. As habitações possuíam uma sala, uma cozinha com jirau e um número variado de quartos, enquanto os dejetos eram depositados no mato ou em fossa. As enfermidades eram amiúde tratadas com ervas, raízes, cascas e banha na preparação de chás, emplastros, óleos e garrafadas, ao passo que a saúde bucal era preservada escovandose os dentes com cinzas. Alguns confeccionavam sandálias usando palha de arroz ou de bananeira. Em que proporção se particiona a dedicação a cada atividade, contudo, não nos parece algo contabilizado pelo lavrador; por isso, tendemos a localizar o problema mais no âmbito de que elementos balizam tal mecanismo de reprodução.

\footnotetext{
${ }^{28}$ Cf. cap. 1. Podemos ainda perguntar até que ponto a mera existência da Lei teria efeito na forma como se concebe o acesso a terra, reafirmada, aqui, no juízo hodierno de nosso entrevistado, ao olhar para a época em que se instalou no Limão.
} 
Já a relação dos produtores com o comerciante pode se circunscrever, em seu nível mais elementar, a uma troca entre o que foi adiantado e o desconto no que depois se converte em víveres não produzidos na lavoura.

Bia: Aí que prestou o ano que vem, que deu um legume bom. Muita gente que quis pagar foi lá e pagou o homem. Muitos caiu fora e ficou assim.

D.L.: Aí ia no armazém e trocava pela produção de vocês? Como era?

Bia: É. A gente pegava os geno [gênero], né, o que precisava, e ele ficava com o dinheiro, né, descontando. Aí o balanço, descontando no total.

D.L.: Ele pagava pra montar o roçado?

Bia: É, ele que dava toda a assistência. Mandava botar arroz, feijão e milho.

No regime de empréstimos que preside a reposição do roçado, os gêneros agrícolas assim produzidos devem ser trocados por outros bens descontados no armazém, de modo que a troca move o processo através de seus agentes. Consoante à investigação da mercadoria em Marx (1. I. t. I, 1985, cap. I), os valores de uso das mercadorias são equiparados no mercado a partir de uma abstração de suas qualidades materiais. Todavia, tal abstração não parece consistir na redução ao caráter comum de dispêndio de trabalho humano ${ }^{29}$ na particularidade que investigamos. Aqui, não há um tempo abstrato que organiza a produção e força à nivelação de trabalhos humanos cristalizados na materialidade das mercadorias. Este processo de substancialização do valor, em realidade, se impõe contraditoriamente. Se o período de chuvas e de estiagem tem um peso no mínimo significativo na reprodução dos sujeitos, condições preexistentes nos rios e na mata são passíveis de apropriação, etc., a mercadoria não pode consistir na forma exclusiva de mediação social.

O mercado é um dos momentos da reprodução analisada, na qual o comerciante compra o arroz encomendado e o passa adiante, para mercados situados além da comunidade:

Imá: A produção que ele mais interessava era o arroz.

Bia: Ele tinha material de beneficiar arroz.

Imá: Que ele botava pra Santarém ou não sei pra onde a produção.

\footnotetext{
29 "A utilidade de uma coisa faz dela um valor de uso [...] O valor de uso realiza-se somente no uso ou no consumo. Os valores de uso constituem o conteúdo material da riqueza..." (Marx, I. I t. I, 1985: 45-6). Porém, "Deixando de lado então o valor de uso dos corpos das mercadorias, resta a elas apenas uma propriedade, que é a de serem produtos do trabalho. Entretanto, o produto do trabalho também já se transformou em nossas mãos. Se abstraímos o seu valor de uso, abstraímos também os componentes e as formas corpóreas que fazem dele valor de uso [...] Ao desaparecer o caráter útil dos produtos do trabalho, desaparece o caráter útil dos trabalhos nele representados, e desaparecem também, portanto, as diferentes formas concretas desses trabalhos, que deixam de diferenciar-se um do outros para reduzir-se em sua totalidade a igual trabalho humano, a trabalho humano abstrato" (ibid.: 47).
} 
Significa também que a encomenda se justifica pela propriedade de um meio de produção; no caso, uma máquina de beneficiar arroz, que por passar por processos industriais ou manufatureiros de limpeza, seria revendido em cidades maiores, que, para além de Santarém, são de desconhecimento do entrevistado.

A propriedade dessa máquina não implica a expropriação da possibilidade do lavrador cultivar seu próprio arroz, tampouco o tolhe de sua subsistência na terra, seja pelo roçado seja pela apropriação direta de condições preexistentes nos rios e na floresta. Salvo a disposição do empréstimo, nada obriga o devedor a trabalhar para dito comerciante, haja vista que aquele possui seus próprios meios de produção. Assim, a relação de dependência consumada entre as diferentes personificações mencionadas deve residir num outro fator, notadamente, na própria comercialização de mercadorias, que se realiza em condições de produção e distribuição particulares. A particularidade, com efeito, passa tanto pelo controle do armazém na comercialização de mercadorias quanto pela posse de "terras livres" pelos lavradores.

A importância dos empréstimos efetuados pelo armazém junto à ocupação fundiária na fundação da comunidade é constantemente recuperada por outros entrevistados. Seu Imá, líder da Associação Ecológica dos Produtores Rurais do Distrito do Limão (ACEPRDIL), narra como a localidade havia sido ocupada, primeiramente, pela lavoura branca, até a demarcação e regularização dos lotes e fundação de um núcleo urbano. A tomada inicial da área fora tarefa presidida pelo comerciante de ascendência sírio-libanesa Miguel Sadeck, ao comprar de diferentes lavradores a produção, sobretudo de arroz, em seu comércio na cidade. Quando Imá chega à área em 1986, vindo de Ourém, o sistema sustentado por Sadeck já estaria extinto, pois nem ele nem seu avô, chegado ao local em 1972, trabalharam com tal comerciante. Parte de sua fala se apoia no relato de um farmacêutico já falecido, que ali atuava junto à Igreja:

Aí ele [o farmacêutico] contava que esse Miguel Sadeck colocou roçado, aí vieram o pessoal da Dona Sinésia, que vieram tudo da banda de Ourém, de lá pra cá. Aí veio Wilson, Gildo, que é o pai do Lalá [...] Ele era o chefe, era o coordenador do trabalho do Miguel Sadeck. Ele quem ia buscar o povo, ele quem trazia e quem dizia [pelo] patrão qual é o trabalho que tinha que fazer. Aí vieram, plantaram esse arroz e ficaram morando, né. Acharam que a terra pra cá tinha mais produção que a terra de lá de onde vieram. Aí quando não tinha mais produção, foram ficando, povoando o Limão.

A perspectiva de análise é de uma ocupação espontânea, entrementes ocorrida, a possibilitar o crescimento da comunidade, visto que "foram ficando, povoando o Limão" mesmo quando 
"não tinha mais produção". Ao mesmo tempo, vemos um desenvolvimento a partir do armazém e a quem cabia interceder no recrutamento de força de trabalho: Sadeck e Wilson (pronunciam "Vilson"). Retornamos à contradição antes suscitada.

Dona Celi, sobrinha de Wilson, exprime numa entrevista como o tio manejava junto do comerciante o transporte de lavradores do nordeste do estado para as plagas do Limão:

Aí ele [Wilson] disse: "rapaz, eu tenho muita gente que mora em Capanema [vizinha de Ourém], e lá tem muita gente que não tem condição de vim, mas quer vim pra cá". Aí o Miguel Sadeck perguntou pra ele: "mas será que se eu falar pra esse povo, ele vem?" Ele disse: “vem. Tão tudo doido pra vim embora". Aí o Wilson vinha e todo mês trazia gente [...] Porque o navio só vinha de mês em mês [...] Ele era o cabeça do negócio.

Mais a frente, Celi descreve que o tio também "dividia roçado já queimado, dividia as tarefa, aquele horror de tarefa de roçado pra cada um daqueles pessoal". Consoante aos relatos, notamos que as famílias pagavam suas próprias passagens. Wilson, por seu turno, é em suma retratado como alguém que, além de ser "o cabeça do negócio", vivia de angariar favores entre grandes comerciantes e políticos. Estes aspectos denunciam a pessoalidade das relações, no sentido de que, nas instituições, público e privado não estão bem discernidos ${ }^{30}$. De alguma maneira, Wilson se beneficia da vinda das famílias e da divisão dos roçados, bem como desfruta de algum prestígio no Limão? Se sim, isso se deve à função de uma espécie de fundador do lugar ${ }^{31}$ ?

Se famílias são trazidas de Ourém, isso consiste num problema de mobilização da força de trabalho (Gaudemar, 1977) pelo território, não obstante seja preciso perguntar das circunstâncias dessa mobilização, isto é, de porque o trabalhador aceita subordinar-se. Recordemos que os lavradores "acharam que a terra para cá tinha mais produção que a terra de lá de onde vieram". Provavelmente, o deslocamento para Monte Alegre é determinado pela viabilidade da subsistência advinda da "produtividade" da terra, igualmente expressando a preocupação com a venda de produtos agrícolas e extrativistas no mercado. O que não aparece é que, desde que chegam, estão submetidos a relações com o comércio, que deve coagir ao trabalho no roçado. Mas a produção não é exatamente determinada pela equiparação de produtos segundo o tempo de trabalho neles dispendido. Se a ocupação da terra é justificada pela "produção", que pressupõe apurações quantitativas, indagamos em que medida não se

\footnotetext{
${ }^{30}$ Cf. cap. 1 e discussão que travamos entre Leal (1975), Muniz (1922) e Toledo (2008).

${ }^{31}$ Abordaremos o papel do fundador de comunidades no capítulo seguinte, no qual é mais pertinente relatar o processo de rápida expansão de povoados de fronteira.
} 
trata de um juízo post festum do entrevistado. Cabe aqui interpretar se a ocupação fundiária se apresenta, digamos, separada do trabalho de roçado, para subsistência e para comercialização, no processo formativo do Limão.

Temos em Seu Dubá e Dona Mazinha mais um relato das relações de trabalho na lavoura. O casal se conheceu já no Limão, um pouco depois de Dubá se instalar no local trabalhando, inicialmente, na construção da estrada - pelo que diz, em 1963. Nessa época, a estrada alcançava apenas a gleba Mulata, distante $30 \mathrm{~km}$ de Monte Alegre e a $24 \mathrm{~km}$ do Limão. Dessa feita, perguntamos da situação do povoado naquele tempo:

D.L.: Mas quando vocês chegaram aqui, já tinha [estrada e comércio]?

Dubá: Não. Aqui tinha um amigo nosso, que ele tinha um homem rico em Monte Alegre que dava dinheiro pra ele fazer os roçado daqui, pra mandar derrubar, e aí mandava fazer o roçado, aí quando queimava ele ia lá em Belém do Pará. Chegar lá ele trazia gente de lá pra morar aqui. Aí vinha esse pessoal tudo foi ele que trouxe.

D.L.: A senhora veio assim?

Mazinha: Não. Nós viemo por nossa conta.

Dubá: Mas o roçado, quem botou foi o...

Mazinha: Quando nós chegamo aqui tinha esse roçado aqui. Só nesse patrimônio. Só era o roçado que tinha aqui. Mas nós cheguemo por nossa conta e tiremo terreno e fomo trabalhar.

Interessa recuperar da expressão "que dava dinheiro pra fazer os roçado" a questão de como é organizada a produção, relatada por Dubá como uma espécie de doação relativa à empreita de formação do roçado. Este juízo corrobora na afirmação de Mazinha quanto à autonomia na posse da terra e mesmo em relação ao comerciante: "mas nós cheguemo por nossa conta e tiremo terreno e fomo trabalhar”. Retrospectivamente, a relação não se define pela impessoalidade entre o proprietário de força de trabalho e o de capital ${ }^{32}$. Mas no que é tomado como "doação", subsiste o sistema do armazém: o comerciante adianta uma quantia em dinheiro ao lavrador, que verte o provento na aquisição de víveres para a satisfação de suas necessidades e, na colheita, paga a dívida contraída com o produto encomendado do roçado, sem cobrança de juros. E segundo Celi, depois de referida quitação eventualmente

\footnotetext{
${ }^{32}$ Lembremos, mais especificamente, dos capítulos II e IV do livro I d'O capital (Marx, I. I t. I 1985). Força de trabalho é uma mercadoria cujo valor de uso é a capacidade de produzir outros valores de uso, e cujo valor de troca é expresso no salário. A força de trabalho deve se constituir mercadoria numa relação de igualdade entre o proprietário de força de trabalho e o capitalista, proprietário de capital. O primeiro vende sua mercadoria ao segundo, em troca do pagamento em salário. Relação determinada pela impessoalidade da troca de mercadorias e salvaguardada pelo Estado.
} 
restaria ao produtor algum saldo em dinheiro - "ainda sobrava uma pontinha pra gente, quando dava"33. Notemos que o dinheiro participa do esquema enquanto adiantamento do processo, diferindo de ocasiões em que abastecimento e pagamento são efetuados em produto (como no cap. 1).

Sadeck não é dono das terras, de maneira a tributar os lavradores mediante o produto do roçado, et pour cause, tampouco logra expropriar estes lavradores de sua base fundiária, mobilizando força de trabalho escravizando ou através de assalariamento ou congênere. A mobilização do trabalho (Gaudemar, 1977) deve ocorrer por outros meios. Diante de tal configuração das relações de produção, parece que Sadeck personifica um tipo de dominação, em torno do armazém, que o permite sustentar o sistema. Vejamos:

D.L.: E esse outro roçado aqui, que esse fazendeiro montou, era de quê?

Dubá: Era só pra plantar arroz, milho, feijão, e ele comprava tudo. Era Mazinha? Miguel Sadeck. Ele comprava tudo. Ele mandava botar roçado e mandava dar o dinheiro, o cara ia lá e trazia muita gente pra cá e tinha que trabalhar e produzir e vender pra ele, que era só o comprador que tinha era ele, não tinha outro.

D.L.: E assim, esse fazendeiro, ele deu a terra ou vocês tinham que comprar?

Dubá: Aqui era do Incra, terra do Incra. A gente pagava no roçado, não era? Pagava no roçado. Ia colher e ele comprava o arroz, o milho, o feijão, mas aí descontava no pagamento, quando era na época.

Segundo o trecho, o lavrador possui certa liberdade no trato de seus produtos justamente por possuir terras, se bem que, por ausência de comprador, deveriam "trabalhar e produzir e vender" para uma única pessoa. Nesses termos, a referida dominação se manifesta como um "monopólio da circulação" por assim dizer, porquanto a mobilização da força de trabalho (Gaudemar, 1977) consistir menos num problema de quem possui os meios de produção ${ }^{34}$ do que de quem pode coagir ao trabalho pelo controle da circulação de mercadorias na área.

\footnotetext{
${ }^{33}$ Poderíamos perguntar, já que não o fizemos durante nossas entrevistas, se e como o lavrador aceitava os preços estipulados pelo patrão. Em que medida a etiquetagem dos preços parte da arbitrariedade do comerciante será tematizado mais a frente.

${ }^{34}$ Segundo Gaudemar (1977, caps. 5 e 7), a formação da mobilidade da força de trabalho na "assim chamada acumulação primitiva" ocorre não somente a partir da expropriação do trabalhador de sua base fundiária; a essa espoliação deve acompanhar um condicionamento ao mundo do trabalho em formação - vide, aqui, as "leis sanguinárias" contra os expropriados, emprestadas da análise de Marx (I. I t. II, 1986, cap. XXIV). O processo de mobilização, entretanto, é analisado segundo a acumulação primitiva inglesa, abstraindo-se as diferentes condições particulares das formações nacionais de capital e trabalho. Esse abstracionismo fora criticado por Carlos Minc Baumfeld, que se debruça sobre as condições de formação da força de trabalho em países de industrialização recente, mais especificamente na esfera da produção agrícola (cf. Baumfeld, 1984).
} 
As relações de fronteira na Amazônia e suas mudanças foram, em especial, exploradas por Jean Hébette e Rosa E. A. Marin (1981) como processo de "expansão do capitalismo", a partir das "diversas formas de subordinação ao capital e [d]as relações sociais vigentes" (ibid.: 188). Estas formas de subordinação, representadas pelo capital comercial, financeiro e industrial, mobilizam força de trabalho no intuito de valorizar capital, realizando-se, assim, como expansão capitalista, servindo-se os autores da tese de Gaudemar (1977). Apesar do foco do texto nos arredores da rodovia Belém-Brasília (BR-010), consideramos sua apreciação pertinente, na medida em que nos permite comparar os elementos aí suscitados com a área que pesquisamos. Nos termos empregados por R. Hartshorne na obra Propósitos e natureza da geografia (1978: 22), o exercício de comparação serve na inter-relação de elementos em comum na definição do caráter da área (cf. nossa Apresentação).

Os autores sublinham que, na fronteira, as relações conferidas no armazém são “incapazes de se apoderar do processo produtivo" e, portanto, de "criar relações capitalistas de produção", sendo tais liames restritos à circulação (ibid.: 201). Para eles,

O comerciante atua como intermediário comercial e financeiro entre os produtores e o mercado, quer seja a totalidade da produção quer seja apenas o excedente comercializado. No seu respectivo raio de influência e segundo a importância de seu capital, o comerciante do interior compra e revende os produtos agrícolas de seus fregueses, aos quais vende por sua vez sua mercadoria, principalmente produtos manufaturados [...] O seu capital não se apodera do processo produtivo e não cria relações capitalistas de produção mesmo se, como é muito frequente, o comerciante "mexe" também com lavoura, pecuária ou indústria, empregando inclusive mão-de-obra assalariada - o que, por si só, não caracteriza uma forma de produção capitalista (ibid.: 201, grifos nossos, D.L).

Assim considerando, a posição de Sadeck é apenas a de um interposto que não se apropria do processo de produção; notadamente, ele não arranca os lavradores de sua base fundiária e os obriga ao trabalho assalariado de produtores de arroz. Os autores supracitados exibem um caso próximo ao nosso, o de um comerciante nas proximidades da Belém-Brasília que, por possuir máquina de limpar arroz, cobra em produto o beneficiamento - na proporção de $38 \mathrm{~kg}$ por saca de $60 \mathrm{~kg}$, ou 63,3\% da produção (ibid.: 201). O cerealista conta com o maquinário para salvaguardar sua posição no comércio, mas a relação também deve figurar vantajosa para os produtores. Sendo assim, o procedimento de beneficiamento (ibid:: 201), 
ao limite, se constitui num serviço ao produtor, que garante aos donos de usina o monopólio da comercialização, prendendo ao usineiro os lavradores que vêm beneficiar a parte da produção destinada ao seu consumo familiar.

Hébette e Marin reconhecem no monopólio da circulação o dispositivo necessário de reprodução do capital mercantil, apropriado "da troca desigual entre os produtos da terra comprado abaixo e suas mercadorias vendidas acima de seu valor", enquanto excedente comercial na forma de "sobrelucro" (ibid.: 202). Apesar disso, lucro, aqui, não pode ser uma categoria deduzida do investimento de capital, e sim da relação comercial pela qual se extrai o excedente. A princípio, o mesmo se aplica a nosso cerealista, já que o abastecimento dos lavradores salvaguarda a posição do comércio na reprodução das relações de produção na área. Ainda que seja possível assinalar, malgrado a apropriação de mais-produto, o excedente se realizando na forma de dinheiro quando os produtos são vendidos, beneficiados, em mercados anônimos. A objeção serve para perguntamos da localização do armazém na reprodução global do capital, mas não distancia deveras do aviamento, nos termos discutidos no capítulo passado. Naquela apresentação de R. Santos (1980), a produção de excedente ocorre justamente da apropriação do produto do trabalho extrativista na esfera da circulação, dada a diferença de preços dos bens comprados e vendidos no armazém.

Além do mais, dito monopólio pode ser justificado pela perspectiva do isolamento da comunidade? Pois bem: alguns entrevistados descrevem a dificuldade pelas quais passavam para acessar centros de mercado, como Seu Dubá:

Imá: Na época que vocês chegaram aqui, a estrada era até a Mulata?

Dubá: Não. Até aqui. O povo ia, saía de manhãzinha e chegava aqui meia noite, né, que os carro não vinha, e os carro atolava aí em meio de viagem, e chegava aqui tudo de pé. Tinha muita gente que trazia os baguio e jogava no mato, que não dava conta de chegar aqui, né?

Para a satisfação de suas necessidades, os moradores deslocavam-se até a cidade, ou ao menos até a Mulata, nos comércios, correndo o risco de o carro atolar e eles precisarem abandonar no mato os víveres recém-adquiridos. Dona Celi, por sua vez, diz nem mesmo existir, enquanto criança, uma casa de farinha - chamada de "casa de aviamento" (cf. Fig. 2) - no Limão, e assim, por vezes, improvisavam um forno com latas de querosene para o fabrico do alimento.

Sei que aí quando era pra gente fazer uma farinha pra comer, a gente não tinha condição pra comprar um forno. Aí meu pai comprava umas lata de querosene [...] aí ele abria aquelas lata e ele colocava tudinho. Sei que três lata ele fazia 
um forninho. Ali, muita gente fazia farinha com aquilo ali, com aquele negócio. Mas passava pouco tempo se acabava, nós tinha que comprar outro.

No seu caso, a família viajava quinzenalmente à Mulata, parte a pé, parte de caminhão, para vender a farinha e comprar mercadorias, retornando a pé para casa. Já no armazém da cidade, descontava a produção em "café, açúcar, sabão, roupa", além do querosene acima referido, sendo que "ainda sobrava uma pontinha pra gente, quando dava", em dinheiro. Aqui, ainda, deveria ser incluída a necessidade dos instrumentos de trabalho: o machado empregado na derrubada da floresta, por exemplo, por não ser confeccionado domesticamente é arranjado no comércio. O mesmo cabe à enxada, pá, terçado e foice usados na formação do roçado e no extrativismo. Esses equipamentos ratificam o monopólio da circulação, pois materializam parte do excedente imobilizado na área, transferindo despesas que seriam do comerciante no comando da força de trabalho e reposição das condições regionais de produção. Operação que nos remete, novamente, à declaração de R. Santos (1980: 162) das parcelas constitutivas da acumulação no contexto do aviamento.

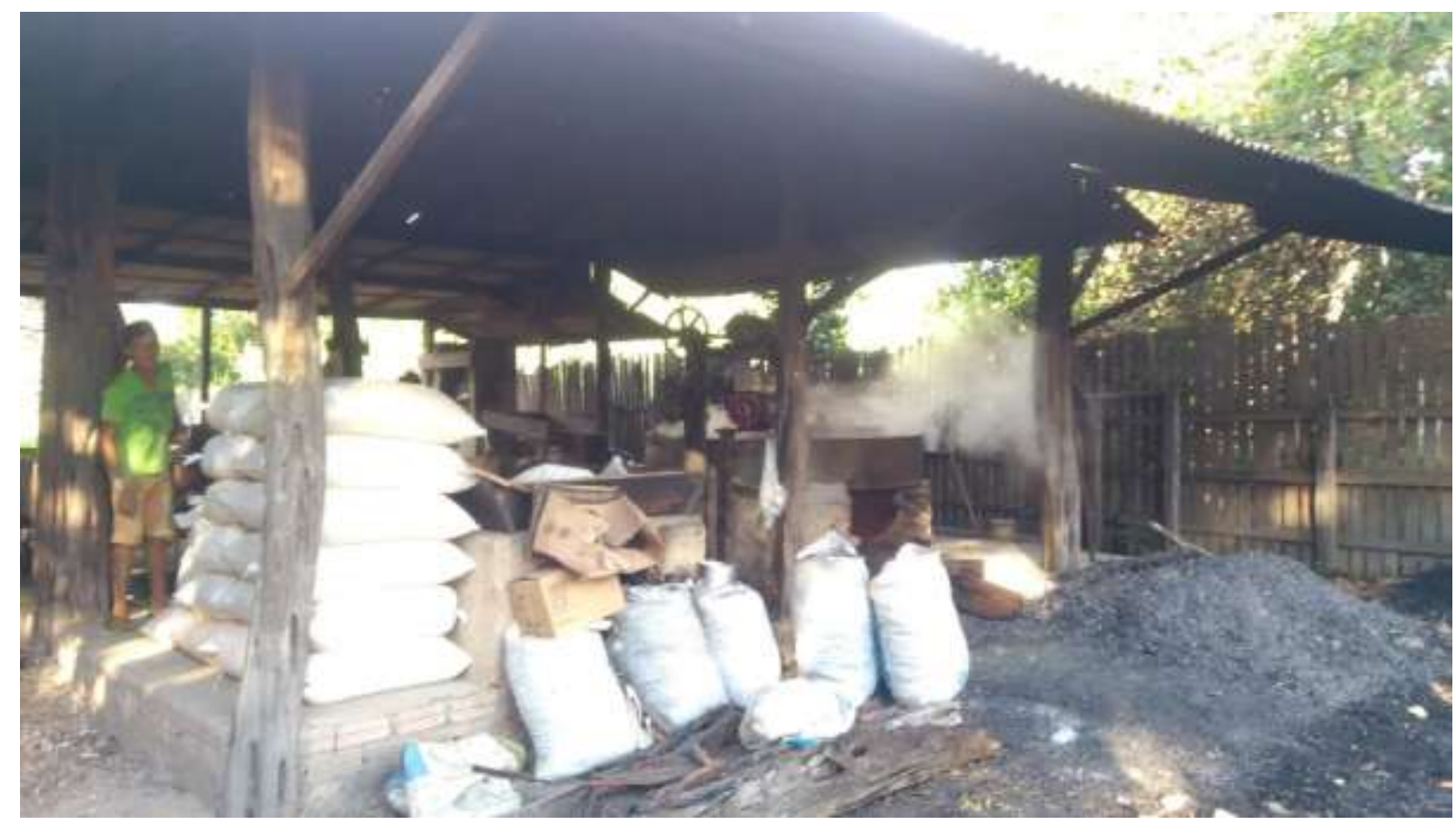

Fig. 2. Casa de farinha no Limão.

Claro, a depender de condições de trafegabilidade, eventualmente as famílias largavam pela estrada bens obtidos ou a serem vendidos. Mas partir da premissa do isolamento físico pode nos desviar a atenção de outros aspectos. Tanto porque essa insulação era bastante relativa, para dizermos o mínimo; apesar dos empecilhos, lavradores frequentavam centros de 
mercado. Isso sem contar que tal premissa enseja o ocultamento, na fisicalidade do espaço, das relações de produção que produzem o espaço. O processo de troca a que nos referimos talvez se reproduza segundo o monopólio da circulação centralizado no armazém, a seu modo. Ao consistir num contexto determinado de relações de produção e distribuição, estas dispõem o que Chico de Oliveira (2008) define como dinâmica regional enquanto forma diferenciada da reprodução do capital, e na qual o político e o econômico, presididos pela classe dominante regional, assumem-se fusionados enquanto pressuposto e produto social (ibid:: 148). O monopólio está legitimado não na propriedade da terra por Sadeck, mas na dominação que este personifica. Dominação reclamada na mobilização do trabalho (Gaudemar, 1977) naquela área para a produção de mercadorias, e exprimida na reiteração dos empréstimos em dinheiro e o desconto em produto, no armazém, do que se produziu.

Portanto, conforme Sadeck "mandava botar roçado e mandava dar o dinheiro", ele comandava o emprego de força de trabalho na produção regional de mercadorias, explorando mais-produto do lavrador, através da apropriação do excedente do roçado sobre o dinheiro adiantado e as mercadorias ofertadas no comércio. Simultaneamente, o lavrador acessar terras devolutas e delas subsistir sugere que sua força de trabalho não está destacada da posse e de alguma independência na reprodução familiar. Notamos aqui que terra e trabalho parecem não-autonomizados no produto social e, resgatando Hébette e Marin (1981: 201), que o comércio não se apropria do processo produtivo.

Talvez por isso faça sentido dizer, Dona Mazinha, que tenha chegado ao Limão "por conta, [a] tirar" um terreno. Prosseguindo a entrevista com ela e Seu Dubá, este relata que o comerciante adquiria "o arroz, o milho e o feijão" descontando na entrega do produto o quantum que havia sido adiantado. Complementa Mazinha:

Mazinha: Mas era o roçado que ele [Sadeck] mandava botar.

Dubá: O roçado que ele mandava botar.

Mazinha: O que a gente botava por conta da gente, ele descontava nada não.

Dubá: A terra não era dele. Terra muito boa aqui. Essas terras não tinha dono.

D.L.: Descontava, como assim?

Mazinha: Assim: Dubá tá dizendo que botava o roçado e quando ele colhia o legume ele descontava o trabalho dele que mandou colocar o roçado, né? Mas nós quando cheguemo aqui não era assim, não. Cada qual trabalhava por sua conta. Agora pra vender o legume, vendia pra ele, porque era só ele que comprava.

D.L.: Descontado era porque ele dava a semente? 
Mazinha: Ele descontava porque era ele que pagava pra botar o roçado [...] Quando cheguemo aqui, já todo mundo trabalhava por sua conta.

Dubá: É. Tirava os lote e botava o roçado por sua conta. Era legal que tava seu roçadinho e já botava é tudo por conta dele. Era tudo por conta dele [do Sadeck]. Isso foi ainda só o primeiro lote, que abriu aqui o Limão. Pra abrir aqui o lugar, foi que ele fez isso. Depois o povo foi chegando e foi tendo os terreno e foi trabalhando. Tendo o roçado, trabalhando e fazendo legume.

Ou seja, é como se os lavradores só como complemento vendessem sua produção, dispensando afirmar a existência de uma sujeição do trabalho do lavrador ao comerciante ${ }^{35}$. Nos termos apresentados, a subsistência se define como trabalho, contraposto ao que fora encomendado, resultando num juízo de independência perante a produção de mercadorias estipulada por outrem. Porque estas diferentes ramificações do trabalho são compreendidas separadamente permite-nos conduzir à temática da jornada de trabalho tal qual elaborada por Marx (1. I t. I, 1985, cap. VIII). O lavrador não é assalariado, e por este motivo, por assim dizer, o tempo de trabalho necessário dedicado à sua subsistência é diverso de um dito tempo de trabalho excedente, dedicado ao comerciante ${ }^{36}$. Mas quando a produção não é mensurada numa temporalidade abstrata, é a materialidade do produto o parâmetro de distinção entre o que serve à subsistência e o quanto é dedicado ao comerciante, que se apropria do maisproduto na forma dum excedente regional. Enquanto que, para o assalariado, a totalidade da jornada de trabalho é indistintamente metamorfoseada em dinheiro, desaparecida a exploração de parte desse tempo na forma de mais-trabalho.

Por um lado, os entrevistados enxergam-se autônomos e vendem a produção a Sadeck por ser este o único comprador. Por outro, inversamente, o patrão é quem impõe a maneira pela qual ocorre a reprodução familiar, pois é quem paga pela produção. Acontece que a apropriação de mais-produto por parte do comerciante, embora seja finalidade, não pode se realizar integralmente, dada a subsistência na terra. Mas o aprovisionamento consiste menos

\footnotetext{
${ }^{35}$ Tomando de empréstimo as análises presentes no Capítulo VI (Inédito) de Marx (1974), a saber, da passagem da cooperativa e da manufatura à grande indústria, seria possível classificar essa forma de sujeição como subsunção formal do trabalho ao capital, em contraposição à subsunção real, na qual o capital se apropria integralmente da força de trabalho, expropriando-a de seus meios de produção com revolucionamentos constantes da base produtiva. Hébette e Marin (1981: 201-2) valem-se desse exame para advogarem a inexistência da apropriação do capital do processo produtivo na Amazônia anteriormente à década de 1960, restringindo-se a uma subsunção formal do trabalho na forma do capital mercantil. No entanto, perguntamos se proceder por essa operação lógica não recairia numa tipologia em que, necessariamente, se devesse passar de uma etapa a outra, e não como momentos que são parte da totalidade processual da sociedade capitalista.

${ }^{36} \mathrm{Na}$ verdade, Marx compara a jornada do trabalhador livre com o mais-trabalho extraído da corveia na constituição do regime de servidão valáquio (Marx, I. I t. I, 1985, cap. VIII item 2). Não é o nosso caso, mas estendemos a análise marxiana por comparação a uma realidade em que não prevalece o trabalho assalariado.
} 
em "relações de dependência pessoal" centralizadas no armazém do que na dependência impessoal representada pelo mercado em constituição, no qual todos socializam forçadamente objetos produzidos pelo trabalho. Os mais diversos produtores privados estão enredados no que Marx define como um "sistema de dependência reificada universal" 37 (Marx, 1. I t. I, 1985: 96, grifo nosso) e, mediante isso, podemos sugerir que as relações presididas pela classe dominante regional são mediadas pela dominação inconsciente da produção de mercadorias. A imposição dessa forma de sociabilidade se realiza como um processo histórico e contraditório de territorialização do capital.

E mesmo a dominação pessoal centralizada no armazém é no mínimo atenuada, no que diz respeito ao conteúdo dos depoimentos sondados. Voltemos a Seu Bia, relembrando seu relato de que, devido à grande incidência de chuvas, a primeira safra de arroz na comunidade malogra, e por isso o comerciante permite que seus devedores o ressarçam no ano seguinte. Permitir que o pagamento seja efetuado posteriormente, porém, não é exatamente o problema, de maneira que observamos o seguinte:

Bia: Muitos pagou, muitos caíram pra fora do pobre do velho e não pagaram $o$ velho, não pagaram. E aí papai pagou a conta dele toda.

D.L.: O que aconteceu com quem não pagou?

Bia: Ele cobrava, mas peão que se dizia aí não pagou não. Não foi mais com ele lá pra pagar, fazer essas coisas.

D.L.: Ainda assim tinha gente devendo?

Bia: Quem tinha vontade de pagar, dava de pagar. Agora, aqueles que não tinha vontade ficava devendo a ele, se desviava, né, pegava o legume e vendia pra outro, não dava pra ele não, pra poder dar o balanço e ir descontando a conta da gente.

D.L.: O Sadeck não proibia ou achava ruim?

Bia: Ele não achava bom não. Ele falava pra nós que sempre paguemo: “ei, e fulano, desapareceu?". “Tá, tá lá”.

D.L.: Mas nunca aconteceu nada?

Bia: Não, ele deixava lá.

Muitos não quitam seus défices, sugerindo alguma fragilização do suposto monopólio da circulação como forma de reprodução do capital na área. Não pagar atenua o argumento,

\footnotetext{
37 “Nossos possuidores de mercadorias descobrem por isso que a mesma divisão de trabalho, que os torna produtores privados independentes, torna independentes deles mesmos o processo social de produção e suas relações dentro desse processo, e que a independência recíproca das pessoas se complementa num sistema de dependência reificada universal" (Marx, I. I t. I, 1985: 96).
} 
que colocamos anteriormente, da sustentação do processo de troca - e da mobilização do trabalho (Gaudemar, 1977) - nesse mecanismo de controle do mercado, o que não exclui sua vigência noutras circunstâncias históricas. Em resposta, o credor não cede novos empréstimos e pergunta pelos endividados aos demais lavradores, mas, ao que parece, não procura acionar procedimentos pessoalmente coercitivos que obriguem ao ressarcimento - até porque não está fora de debate ser tratado o endividamento, por Sadeck, como questão de mérito menor. Ele não ameaça ou coage diretamente os lavradores; tampouco recorre à polícia para reaver seu dinheiro. Neste último caso, o Estado agiria como instituição formada mediando relações de contrato entre iguais proprietários de mercadoria ${ }^{38}$, bem como a fusão entre economia e política, exercida no monopólio do armazém na região, seria projetada no Estado, pondo em dúvida a dissolução das dinâmicas regionais em padrões nacionalmente assegurados de reprodução do capital (Oliveira, 2008: 148-9). Voltaremos a este tema, mais precisamente, no fim do próximo capítulo.

A situação é hipotética, claro. Mas resta supor se Sadeck poderia combinar com outros comerciantes para que estes não vendessem produtos para os que estivessem em débito. $\mathrm{O}$ caso é justamente o contrário, posto que a variedade de comércios na cidade permite ao lavrador jamais recorrer novamente a seu credor - pois "pegava [seu] legume e vendia pra outro". Tanto dever quanto vender para outros a produção suscita o questionamento da função do dinheiro no processo de reprodução do comércio e na região (Oliveira, 2008). Antes de tudo, assinalemos que dever pode em partes ser justificado conforme a possibilidade da família se reproduzir apossando "terras livres" na fronteira, subsistindo e mesmo vendendo sua produção para outrem. Também em partes, a situação analisada, na qual o adiantamento disposto pelo armazém é efetuado em dinheiro, difere dum contexto em que tal antecipação é consumada em produto. Provavelmente, a principal diferença entre as conjunturas consiste em que o dinheiro, até segunda ordem, abre a seu possuidor a liberdade de comprar no comércio

\footnotetext{
${ }^{38}$ Para que ocorra a troca, as mercadorias necessitam que seus proprietários se refiram uns aos outros como iguais, isto é, impedindo que um tome o que interessa do outro pela violência. Marx denota que (I. I t. I, 1985: 79-80), para que "essas coisas se refiram umas às outras como mercadorias, é necessário que os seus guardiões se relacionem entre si como pessoas, cuja vontade reside nessas coisas, de tal modo que um, somente de acordo com a vontade do outro, portanto cada um apenas mediante um ato de vontade comum a ambos, se aproprie da mercadoria alheia enquanto aliena a própria. Eles devem, portanto, reconhecer-se reciprocamente como proprietários privados". Essa relação de igualdade entre proprietários tem a forma jurídica burguesa do contrato. Devemos observar ainda que a relação é entre mercadorias, e seus possuidores tão somente personificam (suas vontades residem nas coisas) as relações econômicas; são eles "máscaras de caráter" da relação. O Estado é o que salvaguarda a reprodução dessas relações contratuais na forma do Direito. Por esse motivo, Kurz (1995: 193) atribui à instituição a função jurídica, tal seja, de juridificar as relações econômicas. A troca de mercadorias que reproduz o excedente regional, contudo, é assente noutros aspectos, como temos visto: o controle extraeconômico da mobilização do trabalho na área e o monopólio da circulação.
} 
em que desejar, sem depender de regressar a seu credor. Contudo, a presença de dinheiro na área parece bastante escassa. E quem deve não pode contrair novo crédito até que pague seu credor.

Dona Celi e seu marido, Seu João André, descrevem uma situação na qual a circulação de dinheiro é exígua: o comércio - não o de Sadeck -, distante do adiantamento monetário, em algum grau se sustenta com base na troca direta de produtos:

Celi: De primeiro, o comércio aí, nós levava coisa pra vender e não tinha o dinheiro pra pagar tudo. Sempre recebia metade em dinheiro, metade em mercadoria, né. É assim que era a coisa, desse jeito.

João André: E aqui a Prainha era pior que Monte Alegre. O comércio de lá era pior que o de Monte Alegre. Porque aqui, fiado ou trocado em mercadoria, a gente vendia. E pra lá, nem isso.

D.L.: O que acontecia?

João André: Eles não queria não, não podia comprar. Ninguém podia comprar o legume, porque o comércio era muito fraco.

Vamos supor que na relação de troca aqui representada, a nivelação necessária entre os produtos, ao menos para o dono do armazém, transcorre segundo uma ideia de equivalente. $\mathrm{O}$ dinheiro não aparece propriamente, embora possa se encontrar presumido no processo como "medida dos valores" das mercadorias. Marx disserta que a mercadoria monetária tem, em primeiro lugar, a função de "representar os valores das mercadorias como grandezas de mesma denominação, qualitativamente iguais e quantitativamente comparáveis" (Marx, 1. I t. I, 1985: 87). Ou então: dinheiro funciona servindo de medida de comparação entre todo o universo das mercadorias, que expressam nele seus respectivos valores (ibid.: 87), às costas dos sujeitos. O produto agrícola pode ser comparado com mercadorias no armazém de acordo com o preço conferido aos gêneros do roçado enquanto "dinheiro imaginário"39 (ibid.: 88) referendado, de certo modo, em cotações de mercados extrarregionais. Suposição que só faz sentido na conjuntura em exame, na qual o crédito de armazém é ofertado em dinheiro.

Todavia, numa realidade pouco monetizada, o usufruto de determinados bens não é mediado pelo dinheiro e, igualmente, o próprio funcionamento do comércio. A reprodução das personas regionais não é exclusivamente determinada pela forma monetária, e portanto sua função de representante de valor não preside absolutamente a reprodução regional. Sequer opera como equivalente geral empregado no processo de troca, posto que, amiúde, esta é

\footnotetext{
${ }^{39}$ Preço e valor não coincidem imediatamente, sendo considerado apenas com fins expositivos, como o faz Marx nos primeiros parágrafos do capítulo do dinheiro n'O capital (I. I t. I, 1985, cap. III).
} 
efetuada em produto, o que nos conduz à pergunta de em que medida a estipulação de preços parte da arbitrariedade do dono de armazém e porque é, ou não, acatada pelo freguês segundo estratégias de dominação pessoal ${ }^{40}$.

Por isso o dinheiro, no contexto da reprodução das relações de produção na fronteira, não opera como um equivalente geral, mediante o qual todas as mercadorias nele refletem tempo de trabalho humano. A distensão temporal entre compra e venda, antes mencionada, e visível no adiantamento da produção do lavrador mediante empréstimo em dinheiro, não configura, na conjectura regional, a função de "meio de pagamento", em que o comerciante é "representante de dinheiro futuro" e, enquanto vendedor desse dinheiro, torna-se credor, como aponta Marx (ibid.: 114). Até porque o pagamento é efetuado, quando o é, em produto. Desse modo, dada a imposição das trocas em espécie e a exiguidade da circulação monetária, é cabível o argumento de que "o desenvolvimento do dinheiro como meio de pagamento exige certa acumulação monetária, nas datas de vencimento das somas devidas" (ibid.: 118).

De certa maneira, podemos dizer que o adiantamento, como crédito na forma de usura por parte do dono do armazém, é reproduzido por meios que não são os do automovimento do dinheiro - dinheiro que gera mais dinheiro. O crédito fornecido não aparece independente do capital comercial pelo qual se adquire dinheiro no mercado (cf. Marx, 1. III t. II, 1986: 107). Se existe alguma garantia de ressarcimento, ela parece ocorrer por algum compromisso moral que comanda a relação entre credor e devedor, amplamente vulnerável por sinal, embora a dominação exercida pelo comerciante seja também suportada na propriedade do dinheiro. Tanto o compromisso moral é fundado na necessidade de dinheiro ou de outros meios para acesso a mercadorias quanto, na área, a maior circulação monetária tende a enfraquecer o monopólio do comércio. Estamos num contexto de transformações.

A digressão é uma reflexão a posteriori das categorias formadas do capital, e sua validade é problematizar o sentido dessa formação categorial real; as relações analisadas não estão apartadas do desenvolvimento capitalista. Objetamos que o problema reside menos na representação do mercado como confronto de valores de uso de produtores independentes, ou mesmo na reprodução de dispositivos que coagem à troca de mercadorias e à apropriação dos

\footnotetext{
${ }^{40}$ Seria proveitoso se conseguíssemos alguma caderneta - que provavelmente existiu - que registrasse os devedores e o quanto deviam. Em geral, esse quantum é assinalado em dinheiro, e a partir dele conseguimos visualizar como o dono de armazém concebe a troca e o preço das mercadorias, mesmo que a diferença de preços não seja contabilizada por um cálculo monetário. Num artigo denominado Le modèle de l'exploitation paternaliste, portanto preocupado com a proposição de um modelo, C. Geffray (1996) analisa como "paternalista" o funcionamento do sistema de dívidas de armazém e as representações associadas. A troca de produtos qualitativamente diferentes ocorre segundo uma "equivalência fictícia" estabelecida pelo patrão entre o que fornece e o que recebe dos clientes (ibid.: 155).
} 
excedentes como lucro comercial por uma classe dominante regional, e mais na localização, no mercado, da socialização forçada dos valores de uso das diferentes mercadorias enquanto trabalho humano geral e abstrato (Marx, 1. I t. I, 1985, cap. I). E essa relação entre coisas é o que confere sentido à reprodução das relações de produção em questão, em processo. Em suma, o sentido é dado pelo aprofundamento da dependência reificada (ibid.: 96) dos sujeitos da forma social determinada pela mercadoria.

Expomos modificações correntes nessas condições de produção apreciando, sobretudo, a função do armazém na formação da comunidade do Limão, não obstante a "livre" posse da terra e a posição frágil que sustenta a obrigação do pagamento das dívidas. Daqui em diante, interessa mostrar como o desenvolvimento desse local se situa na reprodução aparentemente autônoma de famílias lavradoras, traduzida em expansão territorial, e como a ação do Estado e a chegada de novas personas à área vão alterando as relações de produção.

\subsection{Expansão territorial e aparência de espontaneidade}

Como notável, a reprodução pessoal se encontra nos depoimentos analisados passando pelo abastecimento em dinheiro, com base numa conta deixada no armazém, e pela abertura de roçados, com fins de subsistência. Se, antes, relacionamos a reprodução ao comércio aprovisionador do roçado numa coerção para a reposição do mercado, iremos, agora, retomar o desenvolvimento da comunidade da perspectiva das relações de trabalho e com a terra que reiteram um juízo de autonomia, exprimido no crescimento, digamos, espontâneo do Limão.

As descrições que aludem aos tempos iniciais da comunidade oscilam entre apresentar as condições de vida como o que denominam de "sacrificosas" e enquadrar a reprodução no registro da "fartura". Acerca do primeiro caso, relata Dona Mazinha:

Ai meu Deus, quando nós chegamo aqui era muito difícil as coisa. Hoje nós tamo é num mar de rosa. Cheguemo aqui [e] pegamos uma malária de seis meses. Quando se acabou a malária pegou um sarampo, catapora, tosse de guariba [coqueluche], e pra findar de tudo ainda uma coceira com uma dor de barriga que gritava o dia todinho. Foi um ano todo.

D.L.: No ano que vocês chegaram?

Mazinha: Foi o ano de sofrimento quando nós cheguemo aqui. Tinha vontade de voltar, mas uns queria e outros não queria. Aí como é que volta? Agora não. Agora nós tamo é bem. Nós têm água a vontade aí, tem energia (falta às vez dois dias, mas volta). Quem assiste televisão, assiste, quem não quer, assiste rádio, e assim tá bom. Porque, como pode melhorar mais do que isso, 
né. Tem um posto de saúde muito bonito, só não tem remédio. Tem os colégio muito bom, pro pessoal estudar.

As enfermidades são reunidas num conjunto relativo à insalubridade na mata, uma vez que a entrevistada contrapõe as condições de vida, na época da fundação do povoado, às hodiernas.

A fartura, por seu turno, é sempre reiterada quando referida à grande disponibilidade de recursos passíveis de apropriação, como o faz Dubá ao definir como abria seu roçado:

D.L.: Vocês tinham o roçado de vocês aonde?

Dubá: Eu comecei a trabalhar aqui pra dentro. A gente andava daqui $15 \mathrm{~km}$ de pé por dentro do mato aí, e com a máquina nas costa, e ia embora aí de pé no meio da mata. Aí botava o roçado, colhia, botava no barraco e ia atirando em costa de animal, em carroça, aí ia vendendo. Baratinho, mas, nesse tempo as coisa era boa, né, seu menino. Mas tudo era barato aqui.

D.L.: Vendia para o Sadeck?

Dubá: É. Para o Sadeck. A fartura era grande, que a gente matava muita caça, né? Não comprava boia. Era só na caça, do veado, do porco, cotia, essas coisa. A gente matava e ia... assim, o lugar era bom da gente morar, não tinha problema. Era bom aqui. Eu cheguei aqui e tô aqui ainda.

Havendo fartura, como no caso da caça, a "boia" não precisa ser comprada, e a necessidade de dinheiro, ao passo que dispensada na satisfação de uma miríade de necessidades, encontra-se circunscrita ao acesso de apenas alguns bens. Dinheiro pode ser obtido inclusive da venda de recursos diretamente apossados da floresta - como carne de caça e peles -, e dado sua escassa circulação, "tudo era barato", seja o que vendido seja o que comprado. Caso recuperemos algumas das componentes da subsistência dos lavradores outrora expostas, notamos que a construção das casas e dos móveis e a constituição de parte amplamente apreciável da dieta e dos medicamentos provém de materiais usufruídos da mata e da roça e domesticamente confeccionados.

A comparação entre passado e presente é sempre suscitada nas narrativas, variando o julgamento, de positivo a negativo, de acordo com a perspectiva esposada. O passado é descrito como período de dificuldades caso cotejado com a atualidade das condições materiais de vida, a partir do acesso a bens de consumo que, via de regra, demandam dinheiro: a energia elétrica que possibilita assistir televisão, o rádio, e, talvez, tratamento com remédios obtidos na farmácia e compra de material escolar. E se somamos a tal retrato das condições materiais os percalços antes assinalados quanto ao alcance da cidade, podemos supor que o juízo das melhorias, segundo os depoimentos, está concatenado à intervenção do Estado, via construção 
de infraestruturas, e à diversificação do consumo e acesso mais recorrente ao dinheiro, confrontado com o passado de dinheiro escasso e isolamento. Seu João André, por exemplo, comenta que, com dinheiro, "é mais maneiro para ter acesso às coisas".

Os elementos da reprodução familiar pautados na subsistência e que por isso, digamos, dispensam dinheiro, podem ser formulados como arranjos da reprodução independentes da produção de mercadorias. Ou melhor: em vez de independentes, sublinhamos que o trabalho como abstração determinante da reprodução social não poderia, no contexto, estar autonomizado, quer dizer, não poderia ostentar uma existência aparentemente autônoma, do uso da terra - plantio, extrativismo, etc. - na produção de mercadorias, conforme os termos da chamada fórmula trinitária de Marx (1. III t. II, 1986, cap. XLVIII). Segundo o que até então analisamos da formação da comunidade do Limão, terra, trabalho e capital não parecem autonomizados, em nosso juízo retrospectivo. A posição do dinheiro no processo é, por assim dizer, peculiar, pois, adquirido da produção, pode mobilizar o trabalho tencionando a compra de víveres na cidade, mas a imposição desta forma não é exclusiva na determinação da reprodução pessoal.

Assim, formação e manutenção do roçado são momentos da produção de mercadorias agrícolas, que conferem sentido à reposição de uma forma da reprodução capitalista segundo dinâmicas regionais particulares. Todavia, a partir da tese de Toledo (2008), ponderamos que as transformações inscritas na territorialização do capital impõem, enquanto processo de modernização, a autonomização do capital em suas diferentes categorias. A autonomização se dá para além das categorias terra, trabalho e capital e seus respectivos rendimentos presentes na fórmula trinitária, estendendo-se à relação do capital com suas mais variegadas formas de manifestação e de suas polarizações: trabalho e dinheiro; capital e Estado; privado e público; etc. $^{41}$. O processo de desenvolvimento contraditório da forma do capital é o da formação e estabelecimento da aparência de autonomia entre suas categorias.

Nos primórdios do Limão, as famílias são trazidas desde fora por alguma espécie de intermediação da parte de Wilson. A possibilidade de aquisição de terras consideradas capazes de oferecer mais produção, bem como o controle da produção pelo armazém na cidade, são elementos que determinam um deslocamento de tal magnitude. Noutras palavras, um processo de mobilização que, não esquadrinhado pela coerção direta - como já o foi no

\footnotetext{
${ }^{41}$ Esta é uma conclusão a qual chegou diferentes pesquisas do Assim chamado grupo de sexta, e de que nos valemos em nossa investigação. Cf. esp. Toledo (2008), Boechat (2013), Leite (2015) e Vecina (2018). A autonomização também é investigada por Kurz (1992), a seu modo, como desdobramento do processo de modernização, na forma de polarizações como socialismo e capitalismo, Estado e mercado, esquerda e direita, etc., obnubilando a produção de mercadorias como fundamento seu.
} 


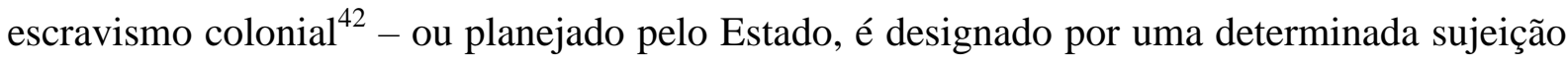
ao trabalho, fusionada com a produção autônoma na terra. A explicação indica que o processo depende tanto menos, detidamente, da vontade racional dos indivíduos, senão de sua personificação duma lógica universal impessoal que se traduz na fundação e desenvolvimento da comunidade pela ocupação crescente da terra, com aparência de espontaneidade.

Como vimos, o surgimento da comunidade é usualmente representado, junto ao empréstimo oferecido pelo armazém, segundo um comum acordo entre lavradores na partilha da terra. $\mathrm{O}$ processo parece espontâneo à medida que famílias vão "chegando e tirando terreno para trabalhar", "cada qual trabalhando por conta" em seu terreno, para parafrasearmos a fala de Mazinha. As tarefas de derrubada da floresta e construção dos roçados são organizadas em equipes, e, se antes havia sido por nós negligenciado no debate, é agora minuciado por Dubá:

D.L.: O senhor abriu muita mata aí?

Dubá: É. Eu derrubei um bocado de pau. Nesses tempo não tinha motosserra, não tinha nada, era no machado. Na foice e no machado, derrubando pau mais grosso que essa jaqueira pra fazer o roçado. Não tinha ajuda de ninguém, era a gente mesmo. Se não podia fazer, nós não fazia. Mas a turma era tudo combinado, e a gente se ajuntava: "bora na casa de fulano", "hoje vamo pra fulano, amanhã vamo pra outro". A gente brocava o roçado e aí ia derrubando de machado. Derrubava, queimava, e ia plantando.

D.L.: E não pagava não, pro amigo?

Dubá: Não, não. Aí nós tava lá por nossa conta, ninguém tinha ajuda de ninguém. Só de Deus. Nós só tinha ajuda de Deus, mais ninguém. Até hoje.

Observamos na abertura dos terrenos a ajuda mútua entre companheiros, com o emprego de instrumentos e técnicas que, talvez, evidenciem um ritmo menos produtivo do trabalho individual ou da família, compensado pelo esforço da coletividade ${ }^{43}$. Para atividades que reclamam emprego mais intensivo da força de trabalho, os lavradores constantemente

\footnotetext{
${ }^{42}$ Baumfeld (1984) designa o trabalho escravo como imobilização absoluta do trabalho, de modo que o escravo não vende livremente sua força de trabalho. A acumulação primitiva no Brasil deveria passar processos de produção da força de trabalho duplamente livre - queira dizer, livre da escravidão e livre dos meios de produção, livre mesmo para perecer (Gaudemar, 1977: 190) -, mas a fronteira aberta impede que ela circule como mobilidade do trabalho na valorização do capital. Toledo (2008: 112) rebate Baumfeld argumentando que o "escravismo no Brasil foi parte do processo de mobilização do trabalho também por ser parte do processo de acumulação primitiva no centro do sistema".

${ }^{43}$ Visto, por exemplo, inexistir motosserra, que foi ali introduzida em meados da década de 80 . Adiantando a conversa, a utilização desse equipamento acelera a transformação da mata em terrenos agricultáveis e pastos, bem como permite que se desenvolva a atividade madeireira com a profissionalização do serrador.
} 
recorrem às empreitadas coletivas. João André define essa prática de mutirão como puxirum, que para ele consiste na troca de dias de serviço:

D.L.: O senhor abriu terreno?

João André: Abri. Acabei com três terreno na mata só à custa das minhas mão. E meus filhos foram crescendo e me ajudaram [...] Eu, [a] bem dizer, era o chefe da mata. Pessoal me botava era de junto pra trabalhar, de derrubada. Me chamava pra mim diministrar [administrar] os trabalhador da derrubada.

Mais a frente:

Sabe quando eu trabalhava? Dia trocado. Que nem, você tá apertado pra colher uma produção de legume [...] Fazia aquele puxirum. Você sabe o que é puxirum? Muita gente junta trabalhando, fazia aquele puxirum e ia todo mundo trabalhar junto. Fazia aquele horror de serviço.

D.L.: Puxirum era mais na colheita?

João André: Era em todo serviço. Pode ser na colheita, pode ser na broca, pode ser na derruba... naquele tempo os homem derrubava. Hoje ninguém quer derrubar mais.

$\mathrm{Na}$ derruba, os mais experientes são designados chefes das tarefas e organizam as turmas, enquanto a troca de dias do puxirum, seja na derrubada, broca ou colheita, acaba por substituir uma contratação que demandaria um dinheiro que os lavradores não possuíam. O esforço coletivo reduz o tempo dedicado por cada família lavradora em abrir seu roçado e produzir ${ }^{44}$. A partir daí, o tamanho da família é uma variável de importância na manutenção da lavoura.

Numa comunidade recém-surgida, a organização das tarefas coletivas ocorre segundo um arranjo vicinal de reconhecimento mútuo. Daí Roberto Araújo (1996) destacar, num artigo dedicado às formas de dominação pessoal e parentesco presentes em povoados de fronteira, que "grupos locais são, em primeiro lugar, grupos de mobilização do trabalho" (ibid:: 246). No geral, esses grupos são constituídos pelo deslocamento de indivíduos que se conhecem de ligações anteriores de parentesco, de afinidade ou de vizinhança, e se reencontram numa nova frente. Segundo o autor, o grupo coloca à disposição das diferentes unidades domésticas sua força de trabalho, tendo por base a troca entre "coisas idênticas", como mesmo número de dias de trabalho, servindo esta troca como "ajuda suplementar" a um lavrador que, caso contrário, trabalharia solitariamente (ibid.: 246). Tal agenciamento, que pode ser virtualmente

\footnotetext{
${ }^{44}$ A. C. G. Leite (2015: 258-9), em entrevista com moradores do Vale do Jequitinhonha, ainda destacaria no mutirão uma organização coletiva do tempo para possibilitar a produção conjunta nos períodos adequados, da semeadura e da colheita.
} 
comportado em relações de parentesco, afeiçoaria então uma etapa da reprodução dos grupos locais, dita indispensável para assegurar a permanência em lugares novos, com penosas condições de vida ${ }^{45}$ (ibid: : 247).

É cabível perguntarmos se a troca entre "coisas idênticas" nos grupos de trabalho é balizada num equivalente, conforme o qual os lavradores se reconhecem como iguais entre si. Em nossa leitura da exposição, parece que há algo nesse sentido em formação, movendo o processo certa comparação de trabalhos distintos, mesmo que tempo de trabalho não seja abstraído como medida exclusiva e determinante de socialização. E justamente por isso, nessa relação de fronteira, inexiste um direito formal propriamente autonomizado no Estado, que regula relações sociais de troca ${ }^{46}$. De resto, a teorização discorrida e a prática do puxirum - tal como descrita por Seu João André para uma nova frente como o Limão - parecem bastante próximas. Lavradores que possivelmente possuíam ligações entre si em Ourém se reconhecem num novo lugar, e trocam dias de trabalho para derrubar e brocar terrenos. Com o puxirum e a expansão territorial, a reprodução do roçado dependeria somente da "cultura" do povoado no que respeita à distribuição fundiária, desencadeando um fatal crescimento da área:

Imá: Tinha uma cultura na distribuição das terra. Você chegava aqui e ia pra capinar numa área que não tem ninguém. Aí você metia um variante, uma vareta, aí entrava um grupo de trabalhador: "aqui é meu terreno; aqui é o meu". Cê tirava, cê não comprava.

\footnotetext{
45 "Os grupos locais são, em primeira instância, grupos de mobilização de trabalho. Eles se colocam ao alcance das unidades domésticas, sobre a base de uma troca de coisas idênticas (mesmo número de dias de trabalho, mesma quantidade de produto, etc.), como braços mais válidos do que eles dispõem assim que chegam a uma região de ocupação recente. Uma ajuda suplementar, e imediatamente disponível, está longe de ser negligenciável nessas circunstâncias [...] Face à dureza das condições de vida sobre áreas recentemente exploradas, a ajuda mútua entre vizinhos é a maior parte do tempo indispensável para assegurar a produção, e é essencial que as relações recentemente estabelecidas entre vizinhos possam, em todo caso, proceder daquilo que comportam virtualmente relações de parentesco" (Araújo, 1996: 246-7, tradução livre). [“Les groupes locaux sont, en première instance, des groupes de mobilisation de travail. Ils mettent à la portée des unités domestiques, sur la base d'un échange de choses identiques (même nombre de jours de travail, même quantité de produit, etc.), plus de bras valides qu'elles n'en disposent à elles seules, et ce dès l'arrivée dans une région d'occupation récente. Une aide supplémentaire, et immédiatement disponible, est loin d'être négligeable dans ces circonstances [...] Face à la dureté des conditions de vie sur les aires récemment défrichées, l'entraide entre voisins est la plupart du temps indispensable pour assurer la soudure, et il est essentiel que les relations nouvellement nouées entre voisins puissent, dans tous les cas, procéder de ce que comportent virtuellement les relations de parenté"].

${ }^{46} \mathrm{Cf}$. nota 38. Para que o equivalente opere como forma objetiva da reprodução, os sujeitos devem internalizar o que Marx chama de "preconceito popular" da igualdade, como qualidade especificamente moderna (Marx, I. I t. I, 1985: 62). O autor sintetiza essa qualidade comparando-a ao pensamento ético de Aristóteles: em uma comunidade escravocrata como a grega, portanto de homens desiguais, parecia legado de impropriedade lógica que coisas qualitativamente diferentes pudessem ser relacionadas entre si como grandezas igualmente mensuráveis (ibid.: 62). Desse modo o trabalho, como abstração real, que se realiza, da materialidade das coisas, não poderia fundamentar as relações sociais.
} 
D.L.: E o tamanho?

Imá: O tamanho era você que limitava.

Dubá: É. Você que mandava. Se você quisesse tirar dez terreno, você tirava, né. Não tinha dono.

A noção de espontaneidade é reforçada por não ter, o terreno, propriedade, de jeito que a posse da terra não se encontra autonomizada da subsistência da roça e do extrativismo, não sendo plenamente mobilizada pelo dinheiro. Todavia, em companhia à "livre" posse de terras, a necessidade de comprar bens de consumo não produzidos pelas famílias lavradoras é solvida na venda de produtos extrativos e do roçado no mercado.

Vejamos que, ao narrar o funcionamento do processo de troca, Imá e Dubá reservam ao armazém uma posição de abastecimento que serve de garantia para quando se esgota o usufruto de recursos da natureza. A cidade é retratada como locus da troca e da transformação industrial, onde se pila arroz para consumo doméstico:

Imá: Aí você tinha lá o peixe [ele fala do terreno recém-apossado], pegava lá o peixe, comia; se tinha caça, matava a caça, plantava a roça. É que nem os índio. Fazia farinha e ia lá comprar o sal. O sal é que não produz. Compra o sal, e tem a farinha, a caça e o peixe...

D.L.: E comprava o sal como?

Imá: Na cidade. Essa viagem que saía era pra comprar as coisa na cidade. Pilava o arroz no pilão, soca o arroz até sair casca, pra poder fazer pra comer [...] Aí tinha uns aqui que quando acabava aquele peixe, acabava aquela caça, ele vendia fiado.

A contradição presente nas formas de reprodução que caracterizam as dinâmicas regionais é sempre reiterada, mas o que interessa no excerto acima, em especial, é que o comércio ratifica a subsistência pela caça, norteando a expansão fundiária num sentido diverso daquele do fiado na encomenda de produtos do roçado. Retomemos do último período anunciado por Imá para prosseguir com o depoimento, que exprime como se dilata territorialmente a comunidade:

[...] Aí tinha uns aqui que quando acabava aquele peixe, acabava aquela caça, ele vendia fiado. Tinha feito um pouquinho de capim aqui, e pulava lá pra frente onde tinha caça.

D.L.: Ele vendia a terra antiga?

Imá: Ele vendia aquilo que ele fez. Aquele capim, aquele... ia e tirava outro terreno pra frente. E assim ia.

D.L.: Quanto tempo demorava pra ele sair de uma terra e ir pra outra? 
Dubá: Depende. Aqui tem muita gente que já foi dono de uns dez lote. Faz um aqui, aí vende, aí vem pra frente, aí vende, aí vai pra frente. Nunca ele come uma fruta assim como eu, ói, que aqui eu, essa "fruteira" fui eu que plantei. Tem muitos aqui que não come. Planta mas não come, porque vai pra outro canto.

Imá: Até hoje tem gente que no final do ramal que tira a terra, aí vai comprando do outro que fez aquela benfeitoria.

O principal mobilizador tanto da passagem de um terreno a outro - o que caracteriza a expansão territorial das relações com a terra na comunidade - quanto da necessidade de emprestar fiado produtos do armazém, é o esgotamento da caça, primeiramente um meio de subsistência. Se a terra abandonada é vendida, não o é por seu caráter de meio de produção não produzido, ou seja, por representar condições não reprodutíveis por meio do trabalho, no caso, a caça; a terra é vendida pensando em suas benfeitorias. No período interpretado, a reiteração de referido processo não deve soar incongruente ${ }^{47}$, dada a magnitude da floresta que poderia ser tomada de posse para derruba, roçado, caça, etc., algo que, por consequência, dificilmente ampararia um mercado fundiário regulado e de intensa operação. Podemos comparar o ocorrido ao que exprimem Hébette e Marin para o caso dos lavradores-migrantes das cercanias da Belém-Brasília:

O lavrador-migrante, o colono que veio de outros Estados em 50-60, não costumou praticar o comércio da terra: ocupava e lavrava. Quando comprava ou vendia, indenizava apenas os serviços e as benfeitorias, não negociava terra devoluta de mata; negociava terreno queimado, roça plantada. Não apropriava a terra, tomava posse dela e quando não dava mais, a abandonava simplesmente (Hébette e Marin, 1981: 208).

A ocupação fundiária, que passa a englobar processos de venda das benfeitorias, é acompanhada de uma ordem de fatores que vai modificando a configuração territorial da comunidade. Nessa época, explica Imá, “aonde era o plantio do arroz [fica] o patrimônio", comandada a fundação deste pelo Estado ${ }^{48}$. Na entrevista que efetuamos com Seu Bia, ele diz

\footnotetext{
${ }^{47}$ Retomando um excerto do capítulo passado, uma das justificativas para desautorizar a inspeção de Muniz, por um lavrador do rio Curuá, é que "as terras devolutas do Estado são do povo e que não é necessário regularisar a ocupação das mesmas, porque acabada a matta de um terreno, vende-se a casa e procura-se outro para viver" (Muniz, 1922: 49). O caso que estamos analisando não parece muito diferente.

${ }^{48}$ Comparada à situação discorrida por Monbeig (1984), o patrimônio fundado pelo Estado difere daquele instituído no oeste paulista a partir da década de 1930 por sua origem, não por suas funções (cf. nosso cap. 3.1.2). Esmiuçar a particularidade paulista exigiria um fôlego que sobrepuja o desta dissertação, mas digamos de passagem que o geógrafo francês assinala uma mudança histórica nos centros urbanos da "franja pioneira"
} 
como o "Incra" - que data de 1970, e, aqui, faz a vez da instituição então em vigor, talvez o Instituto Nacional de Imigração e Colonização (INIC) ${ }^{49}$ - se encarrega de lotear a área e reservar uma parcela da gleba para a rua, onde estão as residências e os comércios.

D.L.: Então nem tinha o patrimônio aqui?

Bia: Tinha não. Quando o Incra chegou começou a demarcar o patrimônio.

Imá: E a ideia é de quem, cumpadi, pra tirar esse patrimônio?

Bia: O patrimônio? Foi na ideia do Wilson, aí ele era muito conhecido, esse cara que trabalhava no Incra na Mulata. Aí nós trouxemo ele pra marcar a área aqui. Aí ele veio e marcou a área todinha. Esse terreno todinho do patrimônio foi ele. Os japonês veio e tomou de conta.

D.L.: Era pra ser do patrimônio ali?

Bia: Era [...] quando chegava no Dubá, dava a volta no marco, lá ele entrava. E disse que depois, os japonês disse "não, é daqui abeirando", e pegaram até ali na casa do Dubá.

O "Incra" agrimensura os lotes e funda o patrimônio, se bem que só compareça à área por obra de Wilson. Mesmo que a ação do interposto ao trazer um funcionário do governo possa, de algum modo, inscrever-se nos termos do favor pessoal, nada exclui que o Estado passa, aos poucos, a gerir as relações fundiárias. A demarcação dos limites da comunidade é conflituosa, pois envolve interesses de colonos japoneses, que avançam da Mulata em direção ao Limão, contra os antigos lavradores, na medida em que aqueles, ao que parece, buscam se apropriar de parcelas de terra onde deveria ser situado o patrimônio. Ainda assim, permanece aberta a alternativa para os lavradores se instalarem em lugares mais distantes, abandonando terras ou vendendo benfeitorias. Nesse caso, a fronteira avança tendo como regulador a demarcação fundiária e a venda a dinheiro. É crescente, aí, a monetarização das relações entre as personas que subjetivam a dinâmica da fronteira.

da fazenda à empresa loteadora, com o fazendeiro trazendo consigo certo número de trabalhadores que, por ventura, transformavam em cidades pequenos patrimônios (ibid.: 240). Mais tarde, grandes companhias planejam a instalação de patrimônios servidos por estradas de ferro e rodovias, cercados de lotes de tamanhos e preços variáveis conforme se distancia do centro urbano, pois "os pioneiros simples têm necessidade de uma praça de comércio para vender e para aprovisionarem-se" (ibid.: 235). Isso não impede que aglomerações em torno de comércios abertos por sitiantes em seus terrenos originem pequenos povoados ou mesmo vilas, "a fornecer ao povoamento rural e principalmente aos pequenos lavradores os seus quadros urbanos" (ibid.: 337). ${ }^{49}$ O INIC surge em 1954 como autarquia vinculada ao Ministério da Agricultura, e é absorvido em suas funções pela Superintendência de Política Agrária (SUPRA) em 1962. É atribuição do INIC "traçar e executar o programa nacional de colonização, tendo em vista a fixação dos imigrantes e o maior acesso dos nacionais à pequena propriedade agrícola; assistir e encaminhar os trabalhadores nacionais migrantes de uma para outra região, e orientar e promover a seleção, a entrada, a distribuição e a fixação de imigrantes no país". Disponível em: <www.fgv.br/cpdoc/acervo/dicionarios/verbete-tematico/instituto-nacional-de-imigracao-e-colonizacao-inic>. Acesso em 03 de março de 2018. Para rápida caracterização dos institutos de colonização e reforma agrária no Brasil, que culminam no Incra, cf. o livreto de Ariovaldo U. de Oliveira (1988: 41-7; 73-8). 
A partir de então, as relações estabelecidas com a terra começam a se alterar na caracterização de determinada relação de produção na fronteira. Para o exame das mudanças observadas, consideramos passar pelas explicações esboçadas por diferentes autores acerca da fronteira amazônica, para então seguir, mas detidamente, por dois aspectos inventariados há pouco. São eles: a) a instituição do Estado nacional fundando o patrimônio e organizando a distribuição fundiária, ensejando um mercado fundiário e a expansão territorial da fronteira, e; b) os liames entabulados nesse processo entre os japoneses recém-chegados e os lavradores já instalados no Limão.

Chegando aqui, temos alguma noção da formação da comunidade e de como inicia sua expansão e as conseguintes transformações na relação com a terra. A princípio, o crescimento do Limão exprime a territorialização da fronteira como expansão capitalista em suas relações determinadas do trabalho com a terra, categorias que se encontram fusionadas (Oliveira, 2008) na reposição do caráter de uma região de fronteira. Tratamos da contradição que move o processo enquanto uma relação de abertura de terrenos para roçados visando à subsistência dos lavradores e à venda de mercadorias na cidade, um tanto sustentada num regime de aprovisionamento por parte de um comerciante especialmente interessado no beneficiamento de arroz. A subsistência das personificações que subjetivam o processo em pauta é guiada pelo fetichismo da mercadoria, no qual o valor contido nos produtos do trabalho humano media as relações sociais, naturalizadas como relações entre coisas. Ou seja, é apagado da materialidade das coisas produzidas privadamente o processo social e abstrato de trabalho que as constituiu. Entrementes, modificam-se as relações de trabalho e fundiárias, relativas ao mercado e ao regime de armazém, tal como a circulação de dinheiro vai se vulgarizando mediando as relações perscrutadas. Precisamos nos perguntar do caráter dessas relações e do sentido de suas transformações, na reposição da região ou na dissolução das relações de produção regionais.

\subsection{Relações de fronteira e o paradigma da "reprodução camponesa"}

A contradição que fundamenta a reposição das relações de produção na área fora, até agora, tomada do viés das relações estabelecidas com o comércio e na posse de "terras livres", que corrobora na noção de espontaneidade que alarga territorialmente a ocupação da fronteira. As pesquisas sobre a fronteira amazônica nas ciências sociais abordam, embora de maneiras distintas, os dois momentos aqui suscitados, relativos aos quais podemos resumir uma seara de tópicos associados: em suma, os trabalhos associam ao tema da fronteira uma apreciação 
sobre o que vem a ser chamado de campesinato e o estatuto da terra na reprodução familiar, divergindo em torno da posição do comércio e do caráter capitalista ou não da relação. Mas talvez principalmente, subsiste nas interpretações a incógnita dos limites da expansão da fronteira como locus da reposição de "relações camponesas" e das funções do Estado na manutenção da autonomia da posse da terra e na criação das condições necessárias para a acumulação capitalista, endossando uma polêmica acerca do caráter da fronteira. Uma trajetória expositiva traçada a partir dos autores elencados permite compará-los entre si e com nossa pesquisa de campo, apresentando em que pontos se aproximam e em que pontos se contrapõem. Tencionamos à problematização dos aspectos assim discutidos segundo o que observamos teórica e empiricamente sem, contudo, esperar qualquer qualificação positiva do caráter das relações de fronteira. Tampouco esperamos encerrar, como nossos interlocutores, um conceito de campesinato, em vez disso optando, aos poucos, por delinear os limites de tal formulação teórica.

Numa de suas primeiras ponderações sobre a fronteira, José de Souza Martins (1975) dedica-se a uma caracterização sociológica da "frente pioneira". Para tanto, inicia sua exposição dialogando com a teoria de Leo Waibel, para quem somente o agricultor estaria apto a compor uma "zona pioneira", uma vez que "capaz de transformar a mata virgem em paisagem cultural” (Waibel, 1955: 391). Daí Martins sublinhar no geógrafo uma pretensão que se volta à efetivação da sociedade urbano-industrial, rotulando como "caracterização geográfica da frente pioneira" o dualismo desta área perante a "zona antiga"; algo que, traduzido na linguagem sociológica, comportaria o dualismo moderno-atrasado (Martins, 1975: 44). Enquanto para a geografia caberia a análise da urbanização como modernização, para a sociologia teria relevância "as relações sociais que tornam singular o sistema social na zona pioneira" (ibid.: 44). Perguntando-se de passagem, por que o autor passa acriticamente pela divisão científica do trabalho?

Ao menos, consideramos que, preocupado com sua sociologia, ele escapa de uma concepção de espaço isenta das relações sociais de produção, porquanto argumenta que "independentemente do espaço geográfico, as relações sociais e singulares que articulam a vida social na zona pioneira não são, por seu turno, 'pioneiras"” (ibid.: 44). Isto é,

Essas relações sociais têm como primeira característica o fato de que articulam a vida social deslocando-se geograficamente, mas preservando-se enquanto modalidade de relacionamento entre as pessoas. O "novo", que é uma das dimensões do conceito de zona pioneira, é novo apenas na ocupação do espaço geográfico e não na estrutura social (ibid:: 45). 
Para Martins, um "novo" referido unicamente à ocupação do espaço permitiria classificar nesta conotação de mobilidade a constituição de uma frente. "Frente pioneira", que contém áreas definidas pela economia de mercado e se apresenta como fronteira econômica, diferente (e amiúde aquém) da fronteira demográfica. O autor, por isso, coloca que a faixa de transição instalada entre as duas fronteiras, embora povoada, não é uma zona pioneira, devido a "sua vida econômica não [estar] estruturada primordialmente a partir de relações com o mercado"; tratar-se-ia muito mais de uma economia de excedente, regulada pela subsistência e só secundariamente dedicada à troca do produto que excede a necessidade (ibid.: 45).

A faixa de transição configuraria uma "frente de expansão", integrada em duas acepções na formação capitalista: a) na absorção do excedente demográfico que não pôde ser contido na frente pioneira ${ }^{50}$, e; b) "pela produção de excedentes que se realizam como mercadoria na economia de mercado", embora as relações não sejam determinadas pela produção de mercadorias, tampouco pela apropriação da terra enquanto "empreendimento econômico" (ibid.: 46). Então, uma frente de expansão não se define exatamente em termos capitalistas: primeiro devido ao uso privado de terras comuns por parte do posseiro. Em segundo lugar, e em conjunto com a apropriação de terras devolutas sem a "equivalência de mercadoria", pela vigência da economia de excedente como "satelitização das relações de troca", cujos rendimentos são absorvidos desde fora numa lógica colonialista (ibid.: 46).

Inter-relacionados os dois fatores, a comercialização do excedente expressa a tensão, na fronteira, entre propriedade capitalista da terra na frente pioneira e reprodução camponesa da frente de expansão. Como pontua o interlocutor:

O excedente é, assim, o artigo que adquire valor de troca porque há condições econômicas para sua comercialização e não porque tenha entrado nas relações de troca como resultado da divisão do trabalho. Na frente de expansão, as condições de vida são reguladas pelo grau de fartura e não pelo grau de riqueza. O empreendimento capitalista se situa "fora" dos componentes da estrutura social da frente de expansão e absorve a renda potencialmente gerada pela terra. Por isso mesmo, as tensões que marcam a frente de expansão são tensões entre a sociedade capitalista que se faz presente na fronteira econômica e a sociedade tribal à qual se disputa [...] a terra necessária à preservação dessa frente (ibid.: 46-7).

\footnotetext{
${ }^{50}$ O princípio demográfico consta inequivocamente na designação da fronteira; contudo, cabe a advertência de Otávio Velho (1981: 12) de que o rápido incremento populacional não explica, senão denuncia a existência da frente de expansão. Para ele, em matéria de migração, a frente é uma alternativa à urbanização (ibid.: 14).
} 
A expansão da frente pioneira pautada na propriedade da terra ocorre pela compra das terras antes apossadas na frente de expansão, não raro desencadeando conflitos (ibid.: 47). As tensões são "as possíveis e necessárias à acumulação e reprodução do capital”, reproduzindo como parte inexorável à acumulação relações "não-tipicamente capitalistas". Para Martins, capitalista não é a compra-venda de força de trabalho, mas a renda capitalizada gerada da propriedade da terra, ao passo que "não capitalistas" são relações não embasadas no trabalho assalariado e na produção de mais-valia (ibid:: 49). Ele reitera na fronteira a fórmula da “produção capitalista de relações não capitalistas" como necessária à acumulação ${ }^{51}$ (ibid.: 49).

Se a comunidade do Limão, em Monte Alegre, caracteriza a fronteira como uma frente de expansão, na medida em que nasce do uso privado de terras comuns pelo lavrador, a posição de economia de excedente que lhe poderia particularizar, entretanto, deixaria de contemplar alguns dos aspectos observados em campo. Lembremos que o mercado não só se fez constantemente presente na reprodução da comunidade, como mesmo origina esta, com o aporte de roçados por um comerciante da cidade e o monopólio da circulação de mercadorias. Mas não apenas isso. Não exatamente as circunstâncias da venda de mercadorias comandadas pelo armazém é que exprimem relações capitalistas de produção, tanto porque, ainda assim, o Limão poderia ser tratado como caso singular, ou porque a venda dos produtos do roçado, na perspectiva sustentada por Martins, poderia tão somente se tratar dum excedente absorvido pelo comércio; por extensão, acidental. Se as transformações apontadas no encerramento da seção passada significam uma incipiente e gradual passagem da posse à propriedade capitalista da terra, pode ser que os desdobramentos das relações sociais internos à própria comunidade sejam negligenciados.

Uma vez que o intercâmbio é acidental, os produtores são independentes entre si e se confrontam exclusivamente no mercado. Mas aí os caracteres sociais da relação ficam obnubilados na forma de troca simples de coisas úteis (Marx, 1. I t. I, 1985, cap. III). Omite-se que relações de violência extraeconômica capitaneadas pelo armazém impelem à troca. Ainda, estaria pressuposto entre os produtores independentes que comercializam seus excedentes que a divisão do trabalho os inter-relaciona, forçosamente, num "sistema de dependência reificada universal" (ibid.: 96) em formação. Os sujeitos não sabem, mas o fazem.

A nosso ver, em Martins (1975) as condições de vida da frente de expansão, na medida em que "reguladas pelo grau de fartura" (ibid.: 46), apagam a determinação dada pela produção abstrata da riqueza social. Ao compreender o capital "fora dos componentes da

\footnotetext{
${ }^{51}$ Essa discussão fora levantada no capítulo passado, quando apresentamos o regime de colonato.
} 
estrutura social da frente de expansão" (ibid.: 47), ele inscreve a "economia de excedente camponesa" numa totalidade apartada da totalidade em processo da sociedade produtora de mercadorias. Sustentamos que as tensões que subsistem na fronteira não são do confronto entre duas totalidades distintas - expressas em diferentes formas de apropriação da terra -, mas do processo contraditório de territorialização das relações capitalistas de produção; a fronteira viabiliza em sua reprodução uma forma particular da produção de mercadorias.

Já Otávio Velho segue pela esteira das pesquisas em torno da fronteira amazônica, com maior fôlego, em duas de suas obras, originalmente seu mestrado e seu doutorado, debruçados sobre o eixo oeste maranhense-norte goiano (Tocantins)-sudeste paraense. Muitos temas e abordagens se repetem nos dois trabalhos. No primeiro deles, Frentes de expansão e estrutura agrária, Velho ([1972] 1981) situa as frentes de expansão como aqueles seguimentos da sociedade brasileira, portanto confinados aos limites territoriais do país, alocados em áreas anteriormente não exploradas e ocupadas somente por sociedades indígenas $^{52}$ (ibid.: 13). Estas áreas consistem nos limites territoriais da expansão da sociedade brasileira, bem como em áreas "contornadas" pela colonização ou anteriormente abandonadas e em processo de reocupação (ibid.: 13-4).

Em Capitalismo autoritário e campesinato (Velho, [1973] 1979), o autor se detém mais minuciosamente a uma conceituação de fronteira relativa à formação brasileira. Ele qualifica a "base camponesa" como forma subordinada de produção a viabilizar e legitimar uma formação de capitalismo autoritário como projeto nacional de modernização (ibid.: 49). Vemos que a formulação se aproxima daquela de modernização recuperadora de R. Kurz (1992), como projeto empreendido pelos países terceiro-mundistas na tentativa de alcançar os padrões de produtividade dos países avançados, jamais atingidos. Em Velho, por seu turno, o capitalismo autoritário se estabelece historicamente como "sistema de repressão da força de

\footnotetext{
${ }^{52}$ Objetamos que o encontro com indígenas, no entanto, não é o mesmo do período colonial. Consideramos que o primeiro contato, sucintamente, era mediado pela catequização e pelo aldeamento na submissão da força de trabalho indígena, na realização do que Novais (1983) chama de sentido profundo da colonização na constituição do Antigo Sistema Colonial como peça da acumulação primitiva de capital na Europa. Realização transcorrida na produção de mercadorias tropicais, no sistema monopolista colonial e no tráfico negreiro (ibid., cap. 2). Já no período de avanço da fronteira no interior da Amazônia em meados do século XX, o contato interétnico é mediado pelos mecanismos contemporâneos, regionais e mundiais, de acumulação capitalista. $\mathrm{Na}$ Calha Norte, é marcante a intensificação da friç̧ão entre os Wayana-Aparai e os extrativistas de balata entre a década de 1940 e 1970. Em sua dissertação, intitulada O pluralismo médico Wayana-Aparai, defendida na USP em 1994, Paloma M. D. Lopes escreve que "foram os balateiros que mantiveram um contato mais duradouro com os Wayana-Aparai" (Lopes, 1994: 32), inclusive inseridos no regime de aviamento da balata, servindo a patrões e coletando látex, bem como se casando com balateiros caboclos (ibid.: 33-4). A relação era, "de modo geral, amistosa" (ibid.: 33), embora devamos ver, para além da descrição da autora, como o aviamento reproduzia condições particulares de reprodução do capital, no contexto geral de reposição do valor, com o indígena como personificação do trabalho extrativista.
} 
trabalho" em relação ao desenvolvimento característico do capitalismo burguês. Este envolveria os preceitos ditos "clássicos" da acumulação primitiva (aqui, expropriação), seguidos de acumulação "propriamente capitalista", isto é, assente na exploração de força de trabalho assalariada (Velho, 1979: 40-6). Nas formações nacionais de capitalismo autoritário, o "camponês" operaria como elemento de reposição da acumulação primitiva, subordinado, ou com tendência de combinação, com a "acumulação propriamente capitalista" (ibid:: 49). A acumulação primitiva é explicada como fase baseada na exploração de formas não capitalistas de produção, e então como necessidade intrínseca ao capitalismo autoritário, visto sua impossibilidade de homogeneização estrutural das formas de exploração do trabalho, daí mantendo expedientes de apropriação do excedente camponês (ibid.: 49).

A divergência mais pungente com a matriz teórica de Martins (1975) se situa, pois, na posição do campesinato na reprodução capitalista e na reposição da fronteira. Para Velho (1979), a existência de terras livres apropriadas pelo camponês denominado de "marginal" passa a ser subordinado ao projeto do capitalismo autoritário como forma da apropriação do excedente necessário à acumulação; portanto, a modernização (re)cria o campesinato. Para Martins (1975), diversamente, a manutenção do posseiro na frente de expansão é momento externo à reprodução do capital, apenas pelo excedente articulada à economia de mercado.

O conceito de fronteira empregado por Velho é mais detalhado em sua interpretação do "campesinato amazônico" e das frentes de ocupação do sudeste do Pará (1979, cap. XIII). O autor sublinha que desde fins da década de 1950, o "quadro geral amazônico", de dispersa ocupação humana e desconhecido do restante do mundo (ibid:: 193), vai se modificando. Por um lado, através de medidas estatais e empresariais quanto à fiscalização sanitária, desenvolvimento agrário e abertura de estradas. Por outro, pelo povoamento do interior da floresta, por parte de nordestinos antes inseridos nos seringais ou que eram rizicultores no oeste maranhense (ibid:: 195). A expansão da povoação, personificada num "campesinato marginal”, em suma, segue do vale do Pindaré (MA) para as margens do rio Tocantins, e é representada pela posse seguida do esgotamento ou expulsão da terra, com ocupação de áreas doravante mais distantes, rumo ao norte (ibid.: 197). Com a abertura da Belém-Brasília, intensifica-se o cultivo de arroz destinado ao Centro-Sul; negócio demandado pela venda de alimentos a preços reduzidos no mercado consumidor (ibid.: 197-8). A dilatação da rizicultura representaria, pois, uma progressiva "desmarginalização" deste campesinato, que com suas recompensas passa a criar gado e a se agrupar em vilas e cidades que rapidamente proliferam pelas margens das rodovias (ibid.: 199). 
O processo de "desmarginalização" é digressionado pelo autor segundo uma trajetória do avanço do povoamento na área por ele pesquisada. A expansão da fronteira acompanha o curso de maranhenses que sazonalmente aportavam às cercanias de Marabá para coleta de castanhas e garimpo de diamantes, alternados com a postura usual de subsistirem instalandose em paragens inexploradas da floresta. A predominância da subsistência e o isolamento são as justificativas listadas quanto à marginalização do campesinato ${ }^{53}$, mesmo que os recémchegados por vezes trabalhassem de agregados em fazendas (ibid.: 200). Os castanhais de uso comum foram gradativamente invadidos e reivindicados por fazendeiros que ali passavam a criar gado, compelindo os expropriados à busca de novas terras (ibid.: 201). As famílias expulsas passavam, via de regra, a se reunirem e se concentrarem em agrupamentos fundados em paragens cada vez mais distantes dos cursos dos rios. A ocupação crescente das áreas de terra firme, a partir de então, ocorre em oposição às várzeas dos rios e áreas circundantes. Nos termos de Velho, bem como é recorrente entre os próprios amazônicos, o processo elucidado evoca uma dualidade marcante entre o centro da mata e a beira dos grandes cursos d'água ${ }^{54}$ (ibid:: 203). A expansão e multiplicação dos povoados no centro implicaria numa distinção qualitativa no arranjo ocupacional da fronteira se em comparação com os padrões anteriores, concentrados nas proximidades dos rios:

Até então em toda a história da área os povoados maiores necessariamente pertenciam à beira [...] A não ser por certas áreas próximas aos rios, na maioria dos casos nenhum verdadeiro movimento de fronteira ocorrera até então. O movimento tradicional gênero frente de expansão baseado em geral, na extração vegetal ou mineral, tinha sido a regra geral e isso não levava a nenhuma ocupação permanente significativa da terra. Agora, pela primeira vez, está-se diante de uma efetiva fronteira em movimento (ibid.: 205).

Apenas com a ocupação considerável do centro o uso da terra passa a ser permanente, através do predominante aproveitamento agrícola e da criação para além do extrativismo. Pensando com os termos do autor, podemos concluir que a fronteira consiste no movimento de subordinação do campesinato marginal à economia de mercado enquanto execução de um projeto nacional de modernização. A desmarginalização referida passa do registro do

\footnotetext{
53 "Quando não estavam coletando castanhas, penetravam nas áreas inexploradas da floresta. Aí inicialmente se dedicavam a um modo de vida caracterizado pelo predomínio de atividades de subsistência e por um alto grau de isolamento que os tornava ainda bastante marginais. Todavia, na maioria dos casos continuavam a alternar sazonalmente as suas atividades agrícolas com a coleta da castanha ou a busca de diamantes" (Velho, 1979: 200). Porém, se a coleta de castanhas norteia o deslocamento desse campesinato, por que afirmar que sua reprodução era predominantemente de subsistência? A subsistência não parte de uma abstração do autor? ${ }^{54} \mathrm{~A}$ polarização centro $\mathrm{x}$ beira é outra expressão para a oposição terra firme $\mathrm{x}$ várzea, verificada em campo.
} 
"desenvolvimento camponês "espontâneo" (ibid.: 199) para a extração de seu excedente enquanto forma necessária do capitalismo autoritário. Nessa medida ao menos, o postulado da marginalização e a economia camponesa de excedente de Martins (1975) estão nivelados, e a eles pode ser retomada a crítica à totalidade apartada que tecemos anteriormente. O que resta é a dúvida de se em Velho a subordinação desse camponês, azeitando a engrenagem do desenvolvimento capitalista, realiza-se ad aeternum. Para Martins, também fica em aberto se as condições da recriação do campesinato em sua independência podem sempre ser repostas. As questões representam outra formulação do problema dos limites da reposição da fronteira.

Justamente referido aos aspectos reunidos na senda da marginalização e da economia de excedente, o trabalho de Leonarda Musumeci (1988) criticará como dualistas as acepções teóricas mais frequentes do campesinato e da fronteira ${ }^{55}$. Segundo a autora, boa parte das pesquisas em torno do tema afirma que o camponês-posseiro tem uma concepção não mercantil e não capitalista da terra, cujos direitos de usufruto, oriundos do trabalho, chocamse com as normas jurídicas, e mais, com os próprios fundamentos econômicos e ideológicos do capitalismo (ibid.: 30). A autora reconhece no dualismo campesinato x capitalismo um lugar de análise do problema agrário, a ressaltar aspectos relevantes da dinâmica e dos conflitos característicos da fronteira, não obstante tratar-se de uma versão parcial do que propõe enfrentar, subestimando processos fora de seu nexo explicativo (ibid.: 40-1).

Ela explicita que a noção de "economia camponesa" no dualismo toma a posse da terra como essencialmente orientada para a subsistência e reprodução familiar, conforme um sistema de relações e representações que, embora articulado, é exterior ao capitalismo (ibid.: 30). O conflito de concepções se manifestaria com a chegada de novos agentes portando as concepções dominantes de propriedade, num embate entre "terra de trabalho" e "terra de negócio" que, transposto para a análise da fronteira, qualificaria o desacordo entre "frente de expansão" e "frente pioneira", respectivamente (ibid:: 30-1).

De acordo com Musumeci, a posição dualista, grosso modo, opera de maneira a situar a apropriação de "terras livres" pelo posseiro como fundada no usufruto da terra pelo trabalho familiar, destinado à subsistência. Por ser o trabalho o instrumento da posse, a terra não é apropriável "em si mesma”, inexistindo qualquer sentido de utilização para "prover lucros” e de com ela estabelecer vínculos permanentes: a posse acontece enquanto se realizam os frutos

\footnotetext{
${ }^{55}$ Em resumo, as teses dualistas, de acordo com Musumeci (1988: 19-20), “partem do pressuposto do caráter não-capitalista (ou até anticapitalista) do campesinato, vendo no trabalho familiar, nas determinações inerentes à 'reprodução' dos grupos domésticos camponeses, o núcleo de um sistema econômico e social orientado por valores, objetivos e representações peculiares, essencialmente distintos daqueles que norteiam a economia e a sociedade capitalistas".
} 
do trabalho (ibid.: 32-3). Quando a terra é transacionada, contabilizam-se apenas as benfeitorias (ibid.: 34), e por isso, para o posseiro, "terras livres" seriam aquelas incorporáveis pelo trabalho, enquanto para o capitalista livres seriam terras sem formalização jurídica, ocupadas ou não. Nesse caso, a realização da propriedade privada da terra, pela lei, redunda na expropriação do campesinato (ibid.: 35-6), que pode reagir lutando pela permanência da "terra liberta" ou para se tornar, ele mesmo, proprietário, através do registro fundiário. Estas duas possibilidades de resistência divergem nas leituras do problema, embora partam do mesmo pressuposto: o de que há uma "lógica originária camponesa" perturbada (ibid.: 37-40).

É inequívoco que tais dicotomias atravessam, em grande parte, a obra de Martins (1975) que analisamos. Nela, a economia de excedente que qualifica a produção do posseiro na frente de expansão, regulada pela subsistência e só "secundariamente" voltada à troca, contrapõe-se, embora articulada, à mercadoria e à propriedade capitalista da terra. Em Velho (1979), pode ser que a noção de marginalização partilhe da mesma premissa, apesar de que a subordinação do campesinato reproduza-o segundo os ditames do capitalismo autoritário nacional. Consoante Musumeci (1988: 41), interpretações como essas, apesar de válidas no realce de "algumas dimensões da realidade", minimizam os "conflitos existentes no interior dos grupos camponeses" e reificam as "lógicas" desses grupos como se eles pensassem e agissem em bloco. Para ela, o dualismo muitas vezes negligencia aspectos como as relações de patronagem, estruturantes das frentes de expansão, e o caráter processual de transformação dessas relações (ibid.: 41).

Principalmente quanto ao aspecto da patronagem é que a autora edifica seu argumento geral. Realizando pesquisas no médio rio Mearim (MA), ela disserta que os camponeses das frentes de expansão não se reproduzem isoladamente, tampouco voltados primordialmente para a subsistência, devendo, sua reprodução, inscrever-se num sistema mais abrangente:

os camponeses das frentes de expansão não vivem num mundo à parte, isolado, autônomo, nem sua atividade produtiva se guia única ou primordialmente pela lógica do consumo e da subsistência familiar. Eles estão dentro da sociedade e, de um modo específico, participam da produção social [...] não é na organização da produção imediata que iremos detectar o sentido da sua atividade econômica e da(s) sua(s) forma(s) de relacionar-se com a terra. É também, e sobretudo, nas relações que inscrevem essas unidades num sistema econômico e social abrangente... (ibid.: 165; sublinhado nosso, D.L.). 
No contexto que investiga, Musumeci alega que a "especificidade da produção camponesa" deve ser esposada em referência às relações integradoras e subordinadoras até certa altura peculiares à fronteira: nomeadamente, o comércio patronal e os vínculos do campesinato com o mercado regional e nacional (ibid.: 166). Nesse sentido, notamos existir em seu argumento um pressuposto de totalidade que preside a particularidade das relações camponesas de produção, sobremaneira mediadas pela patronagem e pelo mercado. Se as modalidades dessa produção camponesa configuram uma dinâmica regional, o são enquanto forma particular da territorialização do capital.

No curso médio do Mearim, para ela, a patronagem é principalmente reproduzida no sistema "informal" de "financiamento" e comercialização de arroz. Sua análise é centralizada nas transações econômicas, devido, como justifica, às dificuldades em organizar a disposição dos agentes do capital comercial envolvidos na relação ${ }^{56}$ (ibid.: 264-5). Daí, distingue sete operações envolvendo o comprometimento antecipado de produtos da roça, sendo o mais comum o empréstimo de dinheiro a juros pelo patrão, com pagamento em espécie da parte do cliente, o produtor (ibid.: 266).

Neste tipo de operação de crédito, o patrão empresta dinheiro ao cliente quando a roça já está formada, ou ao menos, queimada, cobrando juros de $5 \%$ ao mês, enquanto o lavrador acerta suas contas na fase da colheita e quita sua dívida em produto segundo o preço de mercado no período do ajuste (ibid.: 267). Embora a execução de tais condições seja negociável, quase que obrigatoriamente o pagamento dos passivos é consumado em produto. Para Musumeci, trata-se de uma modalidade de transação cativa (ibid.: 269 apud Pacheco, 1980: 25), que amarra o produtor e seu produto à exploração por "instâncias exteriores à 'unidade familiar de produção' [...] compatíveis com a terra liberta" (ibid.: 270) ${ }^{57}$.

Justifica a autora que o provento em produto é mesmo o principal interesse do credor, mais que mera garantia do retorno dos adiantamentos, e, igualmente, mais que a reversão em capital-dinheiro acrescido de juros (ibid.: 270). Para que ocorra o ressarcimento na forma mencionada, os patrões costumam mover penalidades como a suspensão do crédito ou a multiplicação dos juros sobre quem insiste em pagar em dinheiro (ibid:: 271), além de optar por "bons fregueses" e duplicar ou triplicar, para o ano seguinte, uma dívida ainda não quitada

\footnotetext{
${ }^{56}$ Por exemplo: para o usineiro, "produtor" é quem carrega arroz para a cidade, não necessariamente quem planta (Musumeci, 1988: 265).

57 "Logo, as transações cativas, que "amarram" o produtor e seu produto, fazendo com que o seu trabalho seja previamente controlado por instâncias exteriores à "unidade familiar de produção", são compatíveis com a terra liberta, podem prescindir da figura do "proprietário-empresário" e da submissão da força de trabalho ao nível do processo produtivo imediato" (Musumeci, 1988: 270).
} 
(ibid: 274). Estratégias que também poderiam ser mobilizadas por Sadeck, no contexto de nossa pesquisa empírica.

A quantidade de arroz devida varia de acordo com a cotação do produto nas usinas da cidade no instante do ajuste, de modo que o caráter oscilatório dos preços confere à relação, ao invés de uma imposição arbitrária do patrão, a aparência de força imponderável do mercado, à qual todos se submetem (ibid.: 271). Assim sendo, o dispositivo de pagamento em produto funciona eficazmente na concentração da maior parcela da produção, pouco antes da entressafra, em quem mais detém capital-dinheiro (ibid.: 276), de modo que estes, quando vendem a produção congregada, embolsam em dinheiro seus lucros comerciais.

Comparando elementos num exercício de diferenciação de áreas (Hartshorne, 1978) que, contudo, é parte do processo objetivo de territorialização do capital (cf. Apresentação), assinalamos que a cobrança da dívida em juros é, por assim dizer, submetida à reprodução do esquema com pagamento em produto. Em nossa investigação, o défice é quitado, em termos, no período da colheita dos produtos do roçado, mas sem cobrança de juros. O que não sabemos é como os preços no armazém de Sadeck são calculados durante a entrega da produção. Até que ponto os preços resultam da arbitrariedade do patrão e até que ponto são corolário de cotações de mercado extrarregionais é uma dúvida que deixamos em aberto.

Consideremos ainda a cadeia comercial em torno dos empréstimos, posto não haver intermediários entre Sadeck e os lavradores. O comerciante personifica a forma mercantilusurária do capital e se apropria do excedente regional reproduzido na comunidade, de modo a concentrar a produção e repassá-la a mercados anônimos em troca de dinheiro. Só que o funcionamento da cadeia comercial, nos termos expostos, seria apenas uma suposição lógica, uma vez que a salvaguarda da transação cativa (Pacheco, 1980: 25 apud Musumeci, 1988: 269) pelo comércio já parece um tanto fragilizada. Salvo a suspensão do crédito, inexiste multiplicação da dívida, violência direta e outros dispositivos sobre os quais outrora discorremos. Entretanto, se precisam de dinheiro, em muitos casos os produtores têm de recorrer exclusivamente ao comerciante credor. Entretanto também, para além do comando da mobilização do trabalho, mediante a submissão do lavrador ao sistema de empréstimos, por uma classe dominante regional - esteja ou não enfraquecida -, persevera mais agudamente a dependência reificada (Marx, 1. I t. I, 1985: 96) das personas regionais da forma mercadoria.

A discussão travada com os trabalhos que compõem esta seção serviu para comparar elementos suscitados na caracterização da fronteira amazônica com nossa investigação empírica. Os autores descrevem e problematizam relações de produção que reproduzem a 
fronteira e que despontam em mudanças nas relações de trabalho e com a terra, decorrentes da modernização. Algo que na perspectiva dualista qualifica o "avanço" da frente pioneira e da propriedade capitalista sobre a lógica avessa ao capital própria do campesinato. Musumeci (1988), criticando tal polarização, destaca na apropriação de "terras livres" pelo posseiro a mediação de formas de subordinação e integração presididas pela totalidade, dedicando-se à reposição do capital mercantil-usurário na frente de expansão. As modificações concernentes às relações de fronteira, segundo sua perspectiva, não foram ainda explicitadas, e logo serão retomadas. A intenção é que exponhamos, no próximo capítulo, que alterações são atinentes a terra, trabalho e capital na formação gradual de seus respectivos mercados, encaminhando o debate para a relação do designado "fechamento" da fronteira com o planejamento territorial encampado pelo Estado brasileiro. Daqui, indagamos se "fechamento" é outro modo de se referir ao que Oliveira (2008: 149) levanta como dissolução das relações regionais enquanto forma particular da reprodução do capital. Não é demais retomar que o processo se realiza contraditoriamente, sentenciando a mercadoria como forma da mediação social. O fetichismo da mercadoria dá vida aos produtos do trabalho humano, que aparentam manter relações entre si autonomamente. A apresentação de nosso texto é a da constituição dessa relação de mediação. 


\section{CAPÍTULO 3}

\section{DO LIMÃO AO PERÍMETRO: MERCADO FUNDIÁRIO E DE TRABALHO, ESTADO E FRONTEIRA}

Encerramos a segunda seção do capítulo passado elencando dois tópicos que consideramos relevantes na transformação das relações de produção na comunidade do Limão. Eles consistem na chegada do instituto de colonização, delimitando o patrimônio e demarcando terrenos já apossados, e na vinda de colonos japoneses almejando terras. Os lavradores vendem suas benfeitorias, a dinheiro, e seguem floresta adentro abrindo novos roçados, de maneira que começa a operar, ainda que retraído, um mercado fundiário que avança a fronteira para além da localidade apresentada - até então, a de ocupação agrícola mais distante das sedes de Monte Alegre e Prainha. Podemos circunscrever essas alterações ao estatuto reservado a terra e às relações de trabalho e com o comércio como momentos da reprodução de relações capitalistas de produção na área. A territorialização dessas mudanças como forma da modernização é, em grande parte, gestada pela institucionalização do Estado regularizando a terra, tal como pela mais difundida monetarização das relações entre os sujeitos que personificam o processo.

Nossa interpretação se apresenta em três seções, que versam, respectivamente, sobre a formação do mercado de terras, de trabalho e da função do Estado, por meio do planejamento, nesse processo. Desse modo, começamos com a formação do mercado fundiário na área e o avanço da povoação, expressos na proliferação de grupamentos rumo Prainha (a leste) e a nordeste (cap. 3.1). Observamos a ingerência do Estado normatizando a divisão dos lotes ao abrir a rodovia PA-254, de Alenquer a Prainha, guardando suas relações com o movimento da fronteira. O que também suscita questionar, em duas subseções a parte, sobre o "fechamento" da fronteira (cap. 3.1.1) e, em seguida (cap. 3.1.2), a respeito da fundação de povoados, na forma dum debate em torno da função do urbano na fronteira e no deslocamento populacional para a posse de "terras livres". Já no cap. 3.2, abordamos as relações de trabalho mobilizadas na expansão da fronteira e as transformações ocorridas no sentido da remuneração e diversificação do emprego de força de trabalho em busca de dinheiro. Encerrando, no cap. 3.3 tecemos ponderações acerca da institucionalização do Estado, tomando o processo pelas políticas territoriais de planejamento da colonização, construção de estradas e injeção de dinheiro, o que concorre na modificação das relações de produção na área, valendo a pergunta 
da formação de mercados de terra e trabalho segundo padrões nacionalmente determinados de produção.

\subsection{Mercado de terras e avanço da fronteira}

Relembremos algumas passagens enunciadas no capítulo anterior. Na entrevista com seu Bia, ele diz que o "Incra" - qual seja: o órgão que talvez lhe corresponda à época, o INIC $^{58}$ - chega ao Limão esquadrinhando os lotes e os limites do patrimônio. A tanto acompanha a pressão exercida por colonos japoneses, que esperam "tomar de conta" as parcelas de terra que lhes interessam. Como aporta o instituto na área é detalhado no seguinte:

Aí veio o Incra, que tinha um cara aí na Mulata que trabalhava com o Incra assim, né. Era encarregado pra abrir as terra, o Incra, assim pra quem precisava, né. Aí ele entrou aqui no Limão. Abrindo as terra, né, marcando: terreno pra um, terreno pra outro. Aí foi marcando aqui pra baixo, no Limão. Aí papai tirou uma terra lá embaixo: "aqui é pra você. Quem precisar vai chegando aqui e vai marcando".

Manifestamente, a base fundiária não é escassa, porquanto o Estado distribui-la a qualquer um que estiver nela interessado. Pois então, se os japoneses esperam se aproveitar da agrimensura dos terrenos, é porque não basta ter terra: deve-se produzir nela. $\mathrm{O}$ exercício de loteamento segue da gleba Mulata rumo ao nordeste, no Limão, como ocorre com o próprio povoamento, segundo afirma os moradores mais antigos. Durante a década de 1930, a própria Mulata era o ponto-limite da ocupação agrícola em Monte Alegre, e surge como uma das sedes do então instituto de colonização e locus de instalação da primeira leva de imigrantes do Japão na área.

Os terrenos pretendidos pelos japoneses são os limítrofes ao patrimônio, mais próximos da cidade, constringindo-se os antigos lavradores. Na entrevista com Bia, diz Imá:

Sei que o negócio era complicado. Eles entraram aí, e tanto de um lado como do outro eles começaram a apertar. Aí ficou bem estreitinho, só beirando o Limão mesmo [...] De lá pra cá, quando eu entrei naquela rua lá que não tinha a rua, eles queriam limitar no igarapé.

D.L.: O Incra?

\footnotetext{
${ }^{58} \mathrm{O}$ maior impacto nas políticas colonizadoras no período analisado, com a fundação de um grande Projeto Integrado de Colonização (PIC), é encampado na área pelo Incra. Perguntamos se é por esse motivo que os moradores não fazem distinção histórica nem dos institutos de povoamento nem dos órgãos que atuaram junto ao Incra. A confusão também pode nos remeter a determinada concepção da função do Estado como proprietário de terras, como poderá observar o leitor em breve, especialmente na nota 60 .
} 
Bia: Não, os japonês Eles iam comprando de quem morava na beirada e ia comprando os terrenozinho pra botar os dele no igarapé [...] Eles queriam apertar e ia comprando os terreno dos morador pra tomar conta de tudo. Quando vem de fora, vem com fome de terra.

D.L.: Isso era nessa época do Incra ou foi depois?

Bia: Era, nessa época mesmo, que o Incra marcou a terra e começaram a apertar no patrimônio.

Imá: Que os japonês comprou os lote ao lado do patrimônio.

À proximidade do mercado vem a procura pelo acesso ao igarapé como recurso da natureza, ou seja, um bem pretérito que, dado aqui o nível de desenvolvimento das forças produtivas, não é reprodutível pelo trabalho. Ao mesmo tempo, consideramos que uma noção de "recurso natural" independente da mediação do trabalho improcede, na medida em que na natureza não há trabalho contido. Pelo que notamos de algumas entrevistas, a água era preferencialmente acessada do igarapé e transportada em baldes até as casas, ou então cacimbas eram perfuradas, com o risco constante de se deparar o lavrador com água salobra e imprópria ao consumo. Era um risco de quem ocupava uma terra sem saber de suas condições hídricas. Assim também não seria possível, por exemplo, canalizar o igarapé e transferir água para onde quer que fosse. Acesso à água se torna um diferencial na qualidade do terreno. Por isso, a força produtiva do trabalho na terra não é mediada pela aplicação de procedimentos científicos seja no aproveitamento de recursos seja nos métodos de cultivo.

Possivelmente, a produção agrícola proveniente da terra depende de condições que devem retornar na forma de rendimentos a seu proprietário, variando este retorno conforme a localização do terreno, ou melhor, de sua proximidade do mercado e do recurso hídrico. A propriedade da terra por uma classe - expropriando outras - é fonte de rendimentos que Marx denomina de renda absoluta (Marx, 1. III t. II, cap. XLV), e a renda extraída da localização do terreno, bem como de sua fertilidade, configura a renda diferencial I (ibid., cap. XXXIX). Mas mesmo estes critérios devem ser postos em dúvida na área pesquisada; com efeito, os japoneses não possuem o monopólio da propriedade fundiária, haja vista que ainda é possível a quem desejar tirar seu próprio lote, recorrendo ao "Incra" ou simplesmente exercendo a posse de "terras livres".

Se, porém, é objeto de conflito, neste perímetro a terra se torna um meio relativamente escasso, e para tanto em muito corrobora o modus operandi do "Incra". A constituição do patrimônio expulsa os que estavam ali lotados, tal como ocorre com o pai de Bia. Mas principalmente, a tarefa de demarcação não remete imediatamente à titulação: 
D.L.: O que aconteceu com seu pai aconteceu com muita gente? Teve que ir pra mais longe?

Bia: Foi.

D.L.: Por que o Incra não dava título, era isso?

Bia: Não, naquele tempo eles tavam só marcando as terra. Depois que veio outro, pra dar o documento certo da terra. Muito tempo.

Imá: Aqui era só demarcação de terra. Demarcava as terra, aí você vai lá pra documentar. Aí muitos ia, muitos não ia. Ficava trabalhando na terra devoluta, aí não documentava. Aquele que documentava, muitas vezes pegava aqui e passava essa outra, e aí ia se mudando mais pra dentro. Pela divisão da terra também [...] então aquele que pegava a parte menos produtiva queria a mais produtiva, ia praquela outra mais produtiva. Tinha terra de barro, tinha terra de areia, e aí o pessoal ia se mudando.

Quando perguntamos pela titulação, tínhamos em mente que isto serviria de garantia para que a terra não fosse facilmente repassada; talvez o problema estivesse num determinado ínterim entre a demarcação e a titulação fundiária. Mas o problema se reverte justamente no seu contrário: com efeito, a documentação desembaraça a venda de terras ${ }^{59}$. Diversamente de Dubá, apresentado no capítulo anterior, para quem o fator preponderante de transferência de uma terra a outra reside no esgotamento da caça, agora a questão se coloca na produtividade da terra, em função de características do solo cultivado. Num primeiro instante, a distribuição fundiária decretada oficialmente parece ocorrer às cegas no que diz respeito a que terras devem ser apropriadas, sem preocupação com a qualidade dos solos. Quer dizer que a ingerência estatal, aqui, encerra menos uma elaboração organizada da produção agrícola na área do que a afirmação de sua função de controle da distribuição da população num território do Estado nacional em imposição. Nada disso condiz com uma reclamação por melhor organização do Estado, senão uma crítica da própria instituição como agente da modernização e como autonomização categorial do capital. Também, provavelmente em consequência da política fundiária do "Incra", os lavradores disputam as terras mais produtivas através do poder de compra em dinheiro, formalmente, em comum acordo com os vendedores, que avançam para os rincões mais distantes da floresta.

Em termos, a demarcação permite que a base fundiária seja tratada no conteúdo jurídico: o acesso a terra se dá pela lavra de um contrato legitimado pelo Estado. É de se perguntar se a distensão entre demarcação e titulação, ao movimentar o mercado, igualmente

\footnotetext{
${ }^{59}$ Veremos no próximo capítulo como o Estado, às vezes à revelia de seus planos, oportuniza a venda de terra.
} 
permite a especulação com a propriedade da terra, elevando o preço desta. Ao menos, ao facilitar a compra, confere a seus proprietários a possibilidade de retornos monetários. A titulação, portanto, ensejaria a passagem da posse para a propriedade fundiária regulada.

Concomitante a isso, resgatemos uma sugestão apresentada no capítulo passado, indagando se permanecem válidas condições em que a terra é transacionada por suas benfeitorias, e não por configurar meio de produção não produzido pelo trabalho. Nesse caso, nada exclui que o lote passado para frente possa ser adquirido com produtos, ou que compra e venda possam se desenrolar mesmo na ausência de um mercado juridicamente sancionado para a terra. Assim, interrogamos se repassar terras, na época, não figura como algo, por assim dizer, de importância menor para o lavrador, uma vez possível a penetração progressiva para o interior da floresta, daí abertos novos roçados, usufruídos novos campos de caça e extrativismo e, finalmente, fundados novos povoados. Dito de outro modo, em que condições se realiza um mercado fundiário numa fronteira "aberta"?

Avançando rumo nordeste, um dos primeiros povoados formados para além das arraias do Limão é o Perímetro. Seu Chico Bahia declara ter sido um dos primeiros moradores da localidade, já residindo ali quando, em 1979, a estrada a atravessa. Ele aporta em Monte Alegre, vindo do Ceará, em 1970, inicialmente residindo no próprio Limão, trabalhando "nas terras dos outros, de metade". Enquanto meeiro, "tudo que completava", ou seja, o que produzia, "dividia: metade ficava, metade dava pro dono da terra", como outrora fizera com um grande cultivador de algodão no Nordeste. Nessa forma de meação, a produção é tributada gerando renda em produto para o dono da terra, e sob tal arranjo trabalha Chico, por um triênio, com três possuidores fundiários distintos. Na comunidade, ser despossuído parece refletir condições em que a terra é apropriada, entre novos moradores, tão somente por quem pode comprá-la. Do contrário, é preciso integrar-se em relações de trabalho alternativas à posse familiar da terra ou procurar torrões desocupados. Por esse motivo que o entrevistado, após alguns anos, segue para o Perímetro:

D.L.: O senhor ajudou a abrir o Perímetro ou chegou depois?

Chico Bahia: Eu não ajudei assim, mas, quando abriram, eu já tava lá, no meio do mato [...] Aí eu digo "abriram" porque foi assim: quando abriram a estrada, nós já tava lá dentro, no meio do mato.

D.L.: Quem abriu a estrada foram vocês ou foi o Incra?

Chico Bahia: Foi o Incra. Daqui do Limão até o Setor Seis [...] Aí onde eles pararam aqui, tava tudo demarcado.

D.L.: Vocês mesmos demarcaram? 
Chico Bahia: O Incra demarcou. Abriu estrada e foi demarcando. Aí foi e disse: "ói, vocês que não tem terra" (eu era um que não tinha terra) "vocês que não tem terra, parou aqui, a gente não sabe até quando que a verba vai, vocês pega aqui e sai cortando aqui, ó. A enxada marcando, e vocês já fazem o alinhamento de vocês". Aí os terrenos ficavam assim, um do lado e outro do outro, e a estradona no meio. Aí, quando foi antes dum ano, a verba veio, e continuaram. Nós já tinha marcado mesmo: "bora”. Aí abriu até onde era pra ser, até onde era pra ser fizeram. Até chegar na beira do [rio] Jauari.

De acordo com a perspectiva de Chico, a comunidade só é de fato fundada com a chegada do "Incra", construindo a estrada e demarcando os lotes, pois que, antes disso, residiam "no meio do mato". Pode também haver, no trecho, certa noção de espontaneidade, que discutimos no capítulo passado (cap. 2.2), não obstante a intervenção estatal. Intervenção entremeada de insuficiências de recursos, o que, por conseguinte, conduz os lavradores a, eles mesmos, quadrar terrenos, mobilizando suas forças de trabalho. Ponderamos como de maior relevância, porém, a função reservada à PA-254, veiculando a dilatação territorial tanto às relações de juridificação centralizadas no Estado quanto ao aprofundamento da fronteira mata adentro, sobretudo porque é efetuada a venda de terras. Presumivelmente, é o Departamento de Estradas de Rodagem (DER) do estado do Pará o incumbido da construção da rodovia, e não o "Incra", que parece abarcar, para os lavradores, todas as medidas gestadas pelo Estado ${ }^{60}$.

Chico Bahia: Aí terminaram de fazer toda a PA, entregaram tudinho pra nós, começaram a trabalhar, o povo, por fim, começaram a vender, se mudar pra outro canto, e ficou difícil. O povo é assim.

D.L.: Mas por quê?

Chico Bahia: Ia abrir um setor. Vamos supor: vai abrir um setor num outro canto, né. Em outra região. O povo todo corre pra lá. Acha que isso aqui já passou dois ano, três ano, quatro ano... "já tá véio isso daqui”.

D.L.: E o que faz com essa terra?

Chico Bahia: Ele vende pra outro. Aí o outro toma de conta e enche de capim. Que é hoje lá. Ó, hoje lá tem o lugar que produziu, que nós tirava o que, três carrada de milho, de feijão, por semana. De banana. Ainda ficava carga no meio da estrada. Hoje só sai gado daí. Hoje só tem gado.

\footnotetext{
${ }^{60}$ Juízo pertinente mesmo anteriormente às obras de demarcação. Lembremos que, no capítulo anterior, Seu Dubá contesta que as terras no Limão pertenceriam a Miguel Sadeck alegando: "aqui é terra do Incra". É como se o Estado (ou o Incra) fosse o proprietário inquestionável das terras e só ele pudesse estipular o que dela deveria ser feito. Por extensão, podemos sugerir que "terra devoluta" tenha uma mesma conotação de Estadoproprietário, talvez como um raciocínio a posteriori da parte dos lavradores. A situação difere daquela do Cap. 1 , em que as terras devolutas do rio Curuá eram concebidas como "do povo", sem necessidade de regulação.
} 
D.L.: As terras já não tem o mesmo tamanho, então.

Chico Bahia: Tudo cem hectare os terreno. Tudo cem hectare e cheio de capim em cima. Aí ficou o seguinte: tem proprietário lá que não ficou só com cem hectares, só com um terreno. Aí já comprou o meu, comprou o seu, ali cortado... aumentou a área dele. Tem dois, três terreno, tudo de cem hectare.

Gradativamente, o mercado fundiário que se delineia, com aumento da intensidade de processos de compra e venda de lotes, carrega consigo a limitação da quantidade e variedade da produção à pecuária, o que, por consequência, conduz à concentração fundiária. Mesmo que a passagem de um setor a outro não temporize de dois a quatro anos, ela parece célere, tanto porque a mera suposição de abertura de áreas atrai deslocamentos. Diante disso, configura a retaguarda da expansão territorial a inviabilidade do posseamento de terras, o que, em outras palavras, consiste no "fechamento" das "terras livres" da fronteira?

Assim como na cauda do processo reparamos algum ímpeto do mercado fundiário, na ponta de lança da fronteira é patente a posse e a multiplicação de agrupamentos rurais contemporâneos entre si. A abertura da estrada comporta, como tarefa do Estado, a discriminação de setores: um conjunto de lotes de 100 ha no lado esquerdo da estrada, a oeste, em direção a Alenquer, é designado Setor Um; um conjunto de iguais dimensões do lado direito, Setor Dois. E assim por diante, até o Setor Dezessete. Nesse aspecto em especial, nada difere o planejamento executado na PA do que ocorrera na Belém-Brasília, na BR-163, na Transamazônica, etc., em seu modelo de "espinha de peixe" (cf. cap. 3.3).

Em outra direção, o mapa mental produzido no Limão por Avelino exibe a orientação da expansão das comunidades e dos lotes de terra na área em direção leste e nordeste (Fig. 3), pois são grupamentos formados sempre anteriormente à demarcação oficial. Observamos que desde o Limão surge um grande número de patrimônios, beirando a rodovia rumo Prainha, ou seguindo em direção ao rio Jauari, contando, além do Perímetro, Água Branca do Paulino, Água Vermelha, Água Azul, Água Azeda, Novo Brasil, Mata Alta, etc., e alguns mais recentes, datados de meados da década de 1990 em diante, como Vista Alegre do Cupim, Anta I e Anta II e Novo Horizonte. 


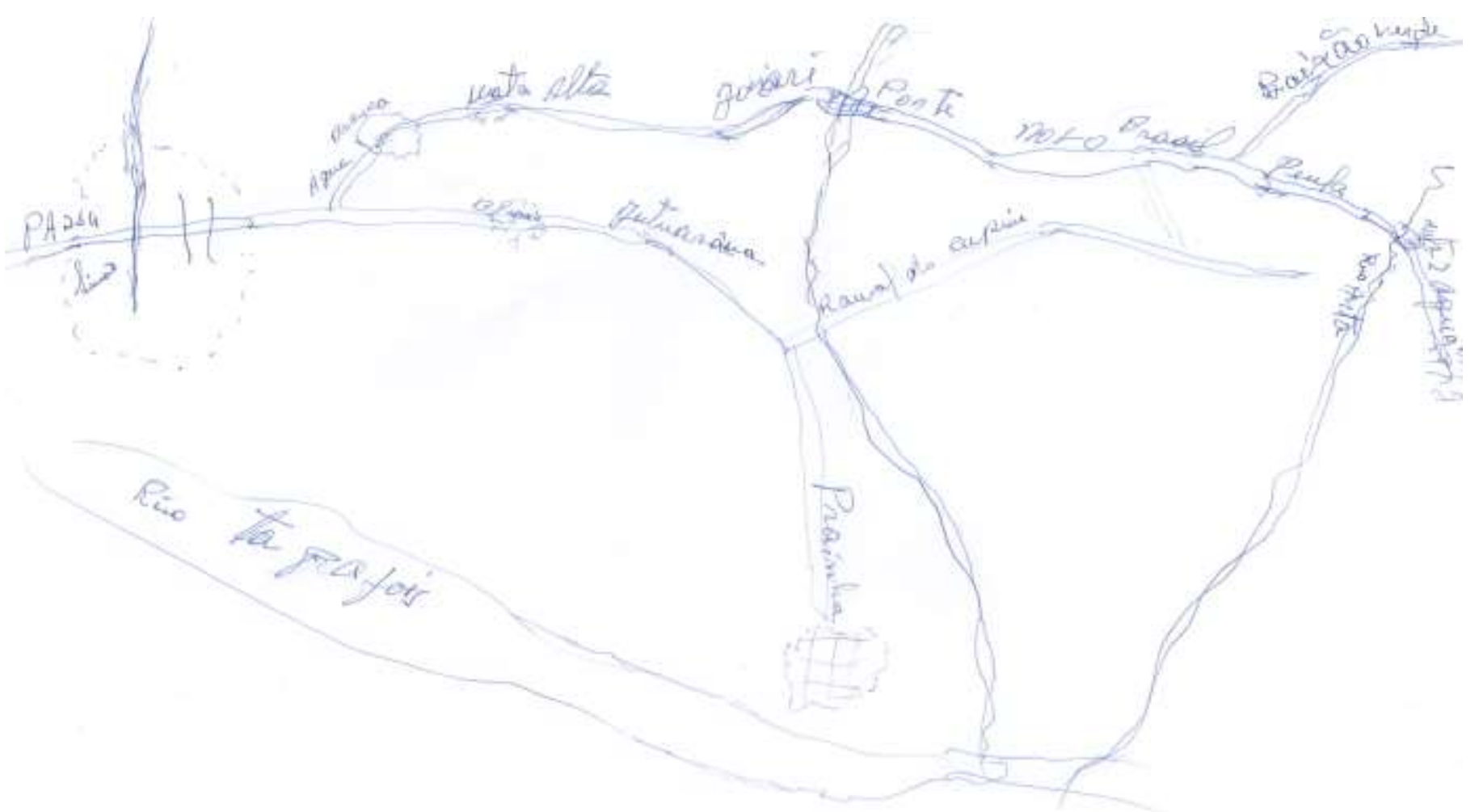

Fig. 3. Mapa mental de Avelino, localizando as comunidades que margeiam a PA-254.

Dizer, como Chico Bahia, que "hoje só tem gado", atesta uma situação inversa da que prevalecia pouco tempo antes, na qual ter uma res e comer de sua carne era bastante insólito.

Quando eu cheguei aqui nesse Pará, cansei de passar de manhã até meio-dia; enquanto tinha um pedaço de carne no açougue nós tava lá tocaiando pra pegar, né, e no fim vinha simbora e não comprava.

Notamos em distintas narrativas que, quando sabiam de algum animal abatido, os lavradores se reuniam no açougue esperando comprar peças de carne. Mas raramente se alimentar de gado não lhes constituía uma falta, visto que caçavam, pescavam e criavam porcos e aves. Em geral, os produtores dispunham de um número bastante reduzido de reses (uma ou duas), para fornecimento de leite e fabricação de laticínios para autoconsumo, e como serventia, digamos, de "poupança”, para os casos nos quais dinheiro era requisitado instantaneamente $^{61}$. Desse modo, a intervenção no intuito do loteamento e abertura da estrada rearranja a produção e a distribuição fundiária, e reverbera inclusive na dieta local.

\footnotetext{
${ }^{61}$ Na dissertação de Janete Gentil (1983), que aborda a queda da produção de juta (erva da qual se extrai uma fibra para a confecção de sacos de aniagem) e a ascensão da pesca comercial no contexto da agricultura de várzea do Baixo Amazonas, a geógrafa também destaca que as poucas cabeças de gado que o ribeirinho possuía serviam de poupança para casos de emergência (ibid.: 116). Sobre a juta, cf. nota 68.
} 
Circunstância que é pertinente às fímbrias da povoação da área, mas não exatamente aos pastos naturais, localizados a noroeste da sede de Monte Alegre e chamados de "campos de desterro" (Fig. 4). São terras que apresentam características de savana e que, segundo nossos entrevistados, desde muito tempo pertencem a fazendeiros, que contavam com vaqueiros submetidos à meação. Melhor dizendo, a cada quatro ou cinco bezerros recémnascidos, tinha o vaqueiro direito a um. Apesar da possessão, era permitido, a quem desejasse, soltar ali seu rebanho, sem qualquer tipo de cobrança. Essa situação começa a se alterar, ao que parece, nos últimos quarenta anos, quando os antigos donos procuram titular e cercar suas terras, vedando que outros pudessem ali criar gado. A relação com os vaqueiros, por outro lado, permanece assentada no mesmo regime.

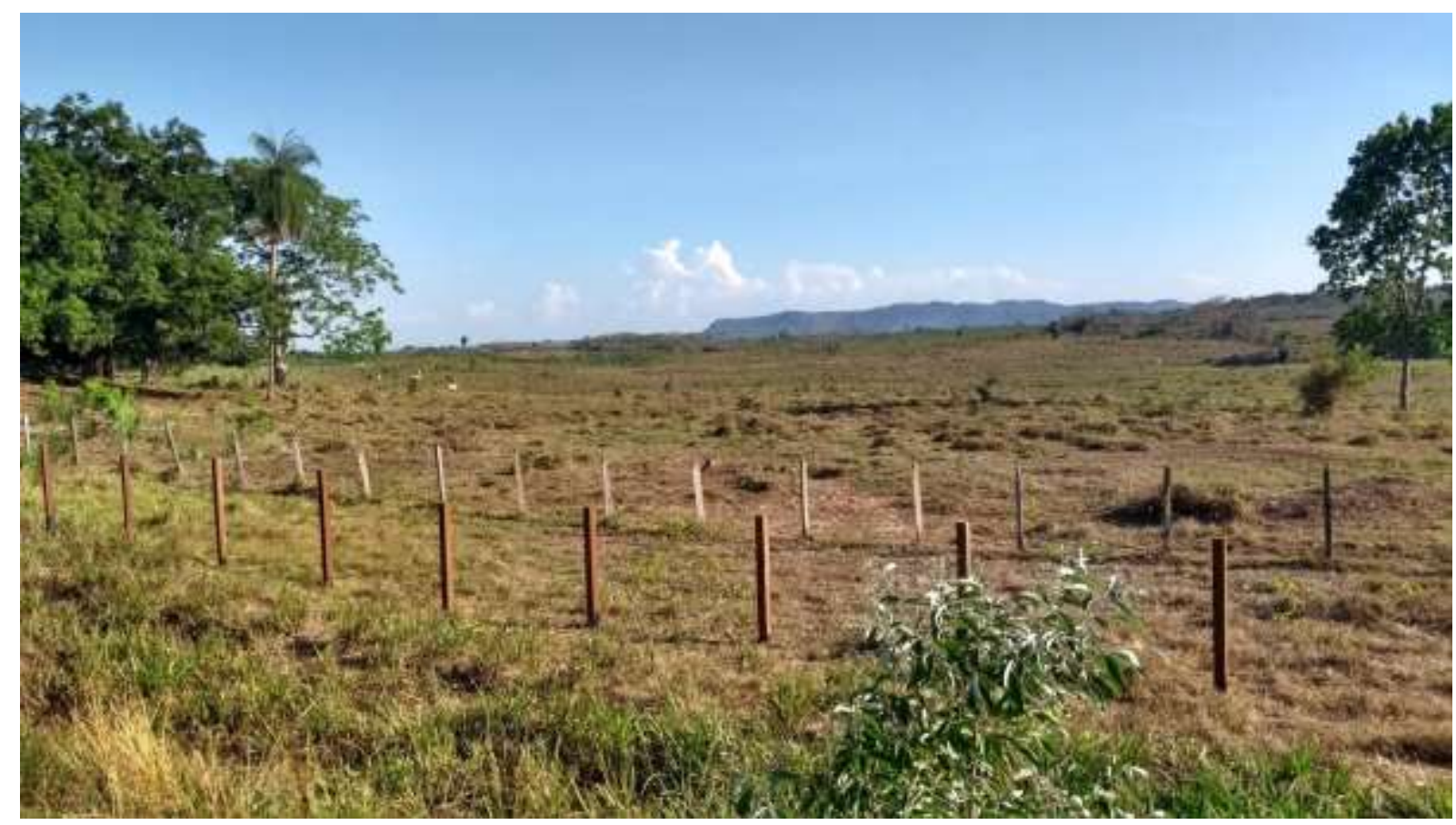

Fig. 4. Campos de desterro.

A partir da análise da entrevista com Seu Paulino, observamos muitos dos elementos que significam transformações transcorridas historicamente em relação ao uso da terra. Ele é potiguar, e chegara a Monte Alegre com cinco anos, fixando-se na comunidade de São Filipe. No início da fase adulta, morava em Dois Galhos, próximo à gleba Mulata, e atravessara do Limão para uma situação na beira do rio Jauari em 1966, com pretensão de lá derrubar a mata e criar gado. $\mathrm{O}$ interlocutor parece adiantar a ocupação de uma área que cresce em população com a passagem da estrada, semelhantemente ao relato de Seu Chico Bahia quanto ao Perímetro. Seu feito parece a todo instante intermediado por instituições representantes do 
Estado: ele chega à futura Água Branca através de um caminho aberto pela Petrobrás, e pede autorização ao interventor do "Incra" para que possa explorar a mata:

D.L.: Como é que o senhor chegou na Água Branca?

Paulino: Porque eu tinha a intenção de criar gado. E aqui o Incra não dava, aí eu queria ir pra mais longe. Aí eu fui pro administrador [do Incra], eu conhecia ele, o dr. Angenor. Aí ele me deu consideração pra ir lá. Fui pelo pico da Petrobrás.

Vejamos que nosso entrevistado residia em uma localidade já loteada pelo "Incra", e que lá, em vista da dimensão do terreno ou outro aspecto, não seria possível criar gado, enquanto que morar na Água Branca, até segunda ordem, oportunizaria o apossamento de qualquer tamanho de terra. Também perguntamos se, no limite, a reprodução que Paulino personifica o insere no registro de precursor, ou mesmo, digamos, de "sócio" da intervenção do Estado, com uma difícil separação entre essas duas funções.

Paulino: Aí depois de três anos, que tô te dizendo, passou um pico. Passou [a] mil metros do meu roçado, da minha casa.

D.L.: Naquela época só tava o senhor ou tinha mais alguém lá?

Paulino: Na época em que passou o pico só tava eu e um cunhado meu, que tinha ido pra lá. Aí quando o pico passou, que a estrada passou, aí eu falei pro Seu Monteiro, e meteu os trator lá, até lá em casa. E limpou tudo, e... tinha muita melancia, muita banana. Tinha três anos. Fiz um barracão grande, de cavaco, e aí deu muita gente, sabe [...] Daí pra casa, eu já vim buscar minha mulher, minhas criança; levei pra lá, fui de morada dele.

D.L.: Eles moravam antes onde?

Paulino: No Limão [...] Ela [ex-esposa] era uma mulher trabalhadeira [...] Aí ela encheu a casa de gente, e [por] uma ordem do administrador [...] Chegava os conhecido, vinham da Canp, da cidade, iam pra lá pra caçar mais eu [...] O meu nome era conhecido, o chefe de lá era eu, aí o homem mandava ordem, o administrador, pra mim cortar a... medir, cortar e entregar pra cada um o terreno, e era todo dia. Chegava dois hoje, amanhã chegava três, amanhã chegava quatro. Com isso, eu não tinha tempo, eu trabalhava dia e noite. E colocando tudo numa reta. Aí eu coloquei 82 colono. O prefeito, o dr. Caniço [?], mandou o trator, pra eu fazer a estrada até lá no último lote. Eu fiz ramal, ponte no igarapé, e aí o movimento cresceu. Aí fiz um... fizeram um campo lá, pra jogar bola, fizeram uma igrejazinha, uma capela. 
Paulino se instala junto de seu cunhado até que o "pico", a estrada, abre caminho para a vinda de mais colonos, hospedados no barracão por ele levantado. Ele angaria, por meio de relações com funcionários do Estado, melhorias infraestruturais, que cimentam a povoação: Paulino e/ou sua primeira esposa (falecida) oferecem as condições para a instalação provisória dos lavradores, que chegam de locais próximos ${ }^{62}$. O Estado mesmo não parece estruturado a ponto de custear o processo de loteamento como um todo, confundindo-se o que é de sua parte com o que é de iniciativa dos próprios lavradores, como o sucedido com a falta de verbas para a demarcação no Perímetro. Para além de certo sentimento de orgulho expresso no depoimento, não parece inoportuno que o administrador do "Incra" solicite a Paulino a organização do fluxo de contingentes.

Por Paulino ser o fundador da comunidade e coordenar as atividades desempenhadas na distribuição fundiária, acaba por atuar como representante do local frente ao Estado e, de certo modo, como representante do Estado no local. Nesse sentido, ele se aproxima de Wilson no Limão, que, além de manter laços com o aprovisionador do povoado e instigar a migração de lavradores de Ourém, divide os roçados e orienta o assentamento das famílias. Na pesquisa realizada por L. Musumeci (1988), o tratamento dado ao fundador da comunidade de Barro Vermelho (em Poção de Pedras, MA) por seus pares é de “dono do centro”. A autora observa:

Quem primeiro "assituava" um local antes inabitado adquiria não somente algumas regalias de prestígio, como escolher o nome do centro (frequentemente o do próprio fundador), mas também um direito, uma espécie

\footnotetext{
${ }^{62}$ Porque os deslocamentos são de curta distância pode ser respondido com o argumento de ainda haver terras prontas para apossamento, mas porque não verificamos (pelo menos não a partir de nossa leitura da entrevista com Paulino) entre lavradores da Água Branca indivíduos vindos de muito longe fica em aberto. Isso é relativo ao ritmo de avanço da fronteira, mais rápido, e que agora mobiliza apenas o trabalho dos agentes próximos, ou isso é uma particularidade do caso em exame? Também precisamos considerar que tais questionamentos não podem ser reduzidos a uma perspectiva de migração que a entende por travessia de pontos fixos de origem e destino, e que, por isso, pressupõem a estabilidade na terra como finalidade. Ao lermos a comunicação de Hébette e Marin (1981: 194), outrora referida, encontramos que: “A maior parte dos estudos sobre migrações e colonização na Amazônia tomam como mira a fixação do colono a terra ou a retenção do migrante num lugar de destino, como se a estabilidade, a fixação ou a retenção fossem o que há de se esperar, o que o sistema social objetiva, o que seria a referência 'normal'”. Ao contrário, os autores focam a migração da perspectiva da mobilidade do trabalho de Gaudemar, como "exigência do capital que precisa tornar o trabalhador o mais perfeitamente móvel para poder subordiná-lo a sua dominação" (ibid.: 194-5). Consideramos assim que, fixação e deslocamento, estão ambos situados na dinâmica capitalista que mobiliza trabalho para se autovalorizar. Pela pesquisa de campo, observamos que os entrevistados migraram diversas vezes, fazendo altamente fluída a noção de origem e destino: um ponto de destino pode servir de ponto de origem para outro fluxo migratório. Igualmente, internamente à mesma área, grupos podem ser atraídos e outros repelidos, ou podem ter suas relações transformadas: enquanto uns chegam comprando terras, outros saem, avançando a fronteira. Podemos dirigir as críticas pronunciadas a Max. Sorre, que define para o geógrafo as migrações como "expressão da mobilidade do ecúmeno" (1984: 126). Sorre pensa em pontos fixos de partida e chegada segundo condições ecológicas, na medida em que o habitat possibilita a migrações (ibid.: seção 2-5).
} 
de posse genérica sobre os terrenos em volta, e certa autoridade para permitir ou recusar a instalação de novos moradores (ibid.: 212).

Algo que é de se interrogar, quanto a nossa pesquisa, é como Paulino (e também Wilson) selecionava que famílias ocupariam os terrenos, e como essa autoridade seria assimilada como simples serviço de instrução ou mando arbitrário de sua parte. Para Musumeci (ibid.: 57), o chefe é uma instância intermediária na arbitragem das "leis" do agrupamento em seu "Direito alternativo", "preenchendo o vácuo deixado pela ausência da Lei”. A nosso ver, interpretar a execução desse corpo de regras comunitário serve na análise de que processos organizam a ocupação fundiária e que relações são estabelecidas e se transformam com a formalização da propriedade. Enquadrar regras consuetudinárias como "Direito alternativo", como faz nossa autora, tende todavia ao quiproquó de tomar os acordos, digamos, informais entre as personas da fronteira por relações instituídas, pressuposto o Estado e o "chefe" como vetor da Lei.

De acordo com o que expusemos, as condições de formação da Água Branca possuem semelhanças com as do Perímetro, enquanto momentos do avançamento da povoação da fronteira. Acerca dos desdobramentos da ocupação fundiária e sua relação com a pecuária, fatores de tal avanço, Paulino responde que, quando abriram a estrada, já criavam gado.

Paulino: Nessa época já tavam começando a criar gado. Eu mesmo comecei a criar gado lá. Aí depois tomou todas as terras e eu mudei pro Setor Um. Aí eu fiz uma fazendinha até boa. Eu cheguei a criar aí seiscentas rês de gado. Era cinco lote, quinhentos hectare. Aí deu um verão forte, secou tudo, e aí ficou difícil. Não tinha energia, não tinha nada. Se fosse hoje eu não tinha vendido.

D.L.: Naquela época, a terra, era só chegar e ocupar?

Paulino: Era. Nem o Incra coisava. Terra devoluta [...] Quando eu entrei pra cá, o Incra já assegurava a terra. Aí eles arrumava uma pessoa como arrumaram eu pra medir. 300 metro por mil.

D.L.: Isso foi depois?

Paulino: Veio liberar pra 100 hectare de 82 pra cá, que fizeram a PAzona aqui [...] Eu tinha 100, e não podia tirar mais não, porque tinha o terreno na Água Branca. Aí eu tirei no nome da minha filha. Aí eu comprei mais quatro lote.

Paulino personifica o movimento já mencionado de concentração fundiária destinada à criação. Na Água Branca, mantém gado até o limiar em que a pecuária aparenta dominar todo o circuito da comunidade. É quando ele se muda para o Setor Um, beirado à rodovia, apesar de permanecer com a terra na primeira localidade. Nesta, a apropriação é pela posse, enquanto nas margens da estrada a ocupação é, inicialmente, fruto de uma concessão do Incra, a partir 
da qual nosso entrevistado concentra 500 hectares de terrenos. Uma vez que o lote-padrão cedido na PA-254 é de 100 ha, ele move estratégias para reunir terras: a compra e demarcação de um quinhão em nome de uma filha sua.

Por seu turno, a venda, se realizada, é sempre a dinheiro. É igualmente patente no fragmento, por assim dizer, a baixa incorporação de capital na produtividade da terra, de maneira que um verão forte, talvez facilmente, faz fracassar a produção. Por extensão, é importante salientar que os agentes que movimentam o mercado fundiário em constituição sejam da própria área. E que não possuam grandes montantes de capital, ao menos a ponto de granjear a conversão da terra em um grande empreendimento produtivo (agroindustrial) ou especulativo, para adiantarmos alguns debates. Nosso entrevistado ora é um lavrador-posseiro e ora é um fazendeiro proprietário de algumas centenas de cabeças de gado - mesmo que a cifra por ele enunciada seja, por ventura, maquiada. Mesmo assim, ele não acumula o suficiente para, por exemplo, enfrentar condições nas quais a seca faz definhar seu rebanho.

Se o gado servia de, por assim dizer, "fundo de reserva" para o lavrador em casos de necessidade incontornável de acesso ao dinheiro, tal serventia pode, agora, valer igualmente para a terra. A venda dos terrenos por Paulino, para além da seca, é explicada na entrevista por motivos que passam pela indispensabilidade do dinheiro, haja vista a reversão deste na construção duma casa na cidade para abrigo da ex-esposa, então enferma. E residir na cidade demanda dinheiro; nesse caso, presumimos, sobretudo para a cobertura de despesas médicas.

E aí o cara chegou com um dinheiro bom. Aí eu vendi [...] Aí minha véia não se deu bem, começou a adoecer [...] Aí fui fazer uma casa na cidade pra ela, doente. Maior dinheiro que eu tinha, entreguei pra essa casa. Aí foi o tempo que ela morreu lá, morreu do coração.

Pecuária extensiva, obviamente, é uma atividade que demanda vasta quantidade de terra dedicada ao pasto. Nossos interlocutores in loco afirmam que cada res consome cerca de 1 ha de capim ao ano, mas por que motivos a produção vai se focando progressiva e especialmente na pecuária não fica exatamente explicitado em suas narrativas. Para começar, consideramos razoável uma justificativa usual, qual seja: a de que gado não requisita esforços demasiados para ser criado e garante retornos monetários assim que seu possuidor necessita.

A geógrafa Janete Gentil (1983), em sua dissertação de mestrado, observa o declínio da produção de juta em Santarém no começo da década de 1980, decorrente da expansão do mercado dessa fibra na Índia. Ela ressalta, nas vinculações da agricultura de várzea com a pecuária, alterações na organização do trabalho e na distribuição fundiária, por ocasião de 
intervenções de pecuaristas de terra firme (ibid.: 121-4). Aqui, historicamente, varzeiro e criador (mormente, um comerciante), mantinham relações de meação, nas quais aquele se encarregava da criação, de modo que, quando as vacas pariam, tinha direito numa parte dos novilhos (ibid:: 121). Segundo a autora, tanto a meação quanto a criação de gado se intensificam em Santarém e arredores desde a década de 1950, quando uma crise no abastecimento do mercado de Belém conduz ao alargamento do rebanho no oeste do Pará (ibid:: 122) e à tendência, entre os pecuaristas, em comprar ou alugar terras dos ribeirinhos (ibid.: 125). Falando nesses termos, a pecuária de várzea em Santarém guarda lá suas similitudes com a formação do mercado fundiário em Monte Alegre, na margem oposta do Amazonas: parece pertinente que a expansão fundiária demandada pela criação seja, também, engajada nas relações estabelecidas com o mercado belenense.

No exame da "evolução do sistema agrário da margem esquerda do Baixo Amazonas", Myriam de Oliveira sintetiza, para o interregno 1970-1990, a ascensão da pesca e a expansão da colonização de terra firme (Oliveira, 2002: 47-56). Conforme a autora, mudanças no sistema de produção foram determinadas, na área, pela crescente ocupação humana e pela queda do preço do tabaco e do algodão (ibid.: 50-3). Mas principalmente, foram determinadas por políticas de valorização da produção agropecuária, por efeito de estímulos à criação de bovinos (ibid.: 50). As medidas se concretizaram com a abertura da PA-254,

facilitando essa entrada [da pecuária], e provocando mudanças na dinâmica de exploração do espaço e alterações na paisagem. Nesse período que o sistema roça-pasto foi adicionado ao tradicional sistema de sucessão cultural de roçacapoeira praticado pelos agricultores e foi a partir dele que se deu um aumento progressivo na formação de pastagens dos estabelecimentos (ibid.: 50).

Ainda segundo a autora, o ritmo de implantação das pastagens ocorreu "mais lentamente" na área, vinculando-se aos procedimentos de manejo guardados das populações nativas - a saber, a preservação de capoeiras - e à barreira que representa o rio Amazonas, algo que conferiu à área um "dinamismo diferenciado" (ibid.: 50). Mas que não impediu mudanças na estrutura fundiária local, ao desencadear um processo de pressão sobre a terra: aqui, Myriam argumenta que a meação, a construção de benfeitorias e a venda de lotes estimularam gradativamente a concentração fundiária (ibid.: 51).

É sintomático que a passagem da predominância de culturas agrícolas para a criação de bovinos seja simultânea à profusão do mercado e a políticas públicas. Por isso, os três fatores se determinam mutuamente, tão embora a inter-relação não resulte necessariamente 
em casos de grilagem e de grande concentração fundiária, como seria de se supor. Aferimos que os lotes muito dificilmente aglutinam mais de mil hectares, bem como, nas franjas abertas na época em questão - entre fins da década de 1960 e início de 1980 -, a grilagem parece um evento raro ou mesmo inexistente. Igualmente, pecuária não deve ser o único fator que suscita a formação do mercado e a concentração fundiária na área. Nem mesmo tal mercado poderia estar exatamente constituído, de certo ponto de vista ao menos, se a posse e o abandono de terras ainda são praticados, ou se no preço da terra são contabilizadas apenas as benfeitorias.

Caso partamos da análise da fronteira em Martins (1975: 47), a regularização da terra, esposada como implantação duma frente pioneira, é resultado da chegada de agentes externos portando a noção capitalista de propriedade, a despeito da posse executada pelo camponês. A conclusão é homogeneizante, na medida em que negligencia transformações internas às próprias personas da área, e como estas passam do posseamento à procura por ações em vista do loteamento. Deslocando a perspectiva, os sujeitos da área por nós pesquisada personificam um processo em que a terra vai, gradativamente, aparecendo autônoma em relação ao trabalho familiar, e pode ser comprada e vendida no mercado. A instituição do Estado acompanha e estimula o movimento dos indivíduos mencionados, regulando o acesso e a distribuição fundiários. Mas comprar, documentar e concentrar terras exige alguma acumulação monetária pretérita - aspecto sobre o qual nos debruçaremos mais adiante.

Com os lavradores passando seus lotes para frente e seguindo para as "terras sem dono" no interior da floresta, compradores e vendedores vão, aos poucos, se confrontando entre si no mercado como possuidores da mercadoria dinheiro e possuidores da mercadoria terra. De certo modo, quem não pode comprar e/ou regularizar terras, vende e avança para novas terras devolutas, sendo além do mais pertinente que se problematize o que se faz com o dinheiro adquirido. A despeito da ausência de grilagem, transcorrem expedientes de expulsão da terra amparados pelas atividades de demarcação, na forma do mercado, e por agentes oriundos da própria área ${ }^{63}$, sem excluir os efeitos do planejamento. Desse modo, podemos sustentar que as relações de produção se modernizam com a autonomização do Estado, por intermédio de políticas fundiárias, e com a monetarização que se desdobra na autonomização

\footnotetext{
63 Assim falando, o processo não transcorreu "de fora para dentro" e pareceu uma continuidade com as relações de produção anteriores. A situação é comparável àquela examinada no médio Mearim por Musumeci (1988), que sintetiza: “No caso que focalizamos, porém, o avanço da chamada 'frente pioneira' não se deu exatamente 'de fora para dentro' nem veio a instituir uma situação completamente nova e radicalmente oposta à da chamada 'frente de expansão'. Ao invés disso, parece ter emergido de diferenças anteriores, acentuando-as, explicitando-as de novas maneiras e, a partir daí, criando novas contradições" (ibid.: 152-3). O fragmento convida a uma reflexão das transformações na região (Oliveira, 2008) pesquisada que, junto à intervenção estatal, são protagonizadas por indivíduos que já moram na área.
} 
da terra em mercadoria, exprimida na precificação do lote. A propriedade da terra vai parecendo, autonomamente em relação à produção, conferir rendimentos a seu possuidor. $\mathrm{O}$ poder aquisitivo do dinheiro representa a imposição do conflito pela apropriação das melhores parcelas de terra: os terrenos mais próximos da cidade e os mais produtivos - "de barro", em detrimento dos solos arenosos - são disputados por conferirem, a seus possuidores, renda diferencial (Marx, 1. III t. II, 1986, cap. XXXIX). Ou seja, para ficarmos com a terminologia de Marx: as parcelas criam sobrelucros na produção em diferença às demais frações de terra que concorrem no mercado, e então se metamorfoseiam em renda fundiária (ibid:: 147). As relações em que a terra está fusionada ao trabalho na reprodução regional (Oliveira, 2008), por isso, tendem a se dissolver na regulação de mercados e na distribuição de formas de rendimento autonomizadas.

Daqui em diante, veremos que a extração dessa forma de rendimento é regulada pela incorporação de terras pelos lavradores e no trabalho despendido por estes na formação de roçados, abrindo caminho para a venda-compra e, por fim, para certa concentração fundiária e especialização da produção na pecuária. Um mercado fundiário pode de algum modo funcionar mesmo com a possibilidade de tomar de posse paragens ainda inexploradas. Em contrapartida, é possível que passar para frente terras, ou mesmo apenas benfeitorias, constitua, da perspectiva dos lavradores, algo que não é mediado pela comparação de tempos de trabalho distintos objetivados em mercadorias. Trata-se dum movimento de fronteira, cujo grau de intensidade com que se processa deve ser questionado, bem como se deve interpelar acerca de seus limites. Ou melhor: até que ponto é capaz de chegar a expansão da fronteira?

\subsubsection{O "fechamento" da fronteira em perspectiva}

Um ensaio de título sugestivo - A porteira está se fechando? - é publicado por Graziano da Silva e reunido num volume que reflete acerca da estrutura agrária, da fronteira e das relações de trabalho na modernização da agricultura brasileira (Graziano da Silva, 1982, cap. 6). A tese apresentada no ensaio é consoante ao restante da obra, qual seja, a de que a fronteira está inserida no desenvolvimento da agricultura brasileira, justificada na forma extensiva pela qual esse desenvolvimento se dá (ibid.: 114). Extensiva porque historicamente operou via incorporação de novas áreas, sempre pressupondo "a existência de uma fronteira a ser ocupada" (ibid.: 115), da expansão cafeicultora à demanda de alimentos e matérias-primas decorrente da industrialização pós anos 1950 (ibid.: 114). Fronteira, pois, não é um "vazio demográfico" externo ao "modelo agrícola” brasileiro (ibid.: 115). 
Para explicar esse enunciado, digamos, endógeno à modernização, o autor parte da procura de alimentos e matérias-primas resultada da industrialização nacional. Para atendimento da demanda, tanto se pode intensificar a produção nas áreas já ocupadas quanto se incorporar novas terras ao processo produtivo, sem independência e, a princípio, sem exclusão entre tais alternativas. Isso porque a renda fundiária - absoluta e diferencial - estaria regulada pelo nível de produtividade dos investimentos capitalistas adicionais sobre a terra:

É como se o desenvolvimento do capitalismo na agricultura, ao enfrentar a questão do monopólio da propriedade da terra e o fato de esta ser limitada em sua disponibilidade, "fabricasse mais terras" explorando cada unidade de área de maneira mais intensiva (ibid:: 115).

Concluímos daí que a abertura de cada nova parcela de terra pode vir com maior intensidade de capital aplicado, e por isso não se isola do nível de desenvolvimento social das forças produtivas. Graziano explica que, uma vez inviável a incorporação de mais terra ao processo produtivo (devido ao incremento da demanda), exige-se maior adubação do solo, emprego de variedades mais produtivas, etc. Se, pelo contrário, há terras disponíveis, a renda é constituída "quase que exclusivamente" pela renda diferencial de localização e fertilidade, em virtude de não se configurar integralmente o monopólio da terra como propriedade privada (ibid.: 116). A ocupação da fronteira é regulada pelo ritmo de intensificação da aplicação de capital, de maneira que uma variável interage com a outra. Nas palavras do autor:

Resumindo, a existência de "terras sem dono" na fronteira funciona como um regulador da intensificação da agricultura, condicionando assim o seu desenvolvimento extensivo/intensivo. Em sentido contrário, o custo adicional da intensificação pelo capital determina o ritmo da incorporação produtiva das terras na fronteira (ibid.: 116).

Pensando nesses termos, a renda absoluta extraída do monopólio da propriedade da base fundiária quiçá não se realiza em nosso contexto. Não obstante a pretensa efetivação da propriedade nas imediações do patrimônio mais próximas da cidade, permanece factível ocupar "terras livres", sendo o ritmo da incorporação destas, ou melhor, o avanço da fronteira, regulado pelo nível global de aplicação de capital. Pode ser que não se verifique de pronto, e in loco, investimentos consideráveis de capital que resultem em diferenças no nível de produtividade da terra e do trabalho que confiram renda a seus proprietários. Os rendimentos parecem restritos à localização e fertilidade do solo. 
Já o "fechamento" da fronteira, conforme Graziano, na realidade implica que "terras livres" não podem mais ser apropriadas por "pequenos produtores de subsistência" (ibid.: 117). Terras não ocupadas existiriam, apesar de nelas estar etiquetado um preço, portanto sujeição a procedimentos de compra e venda legitimados por uma definição jurídica de propriedade. Na Amazônia, pois, o "fechamento" não se daria exatamente pela expansão das áreas cultivadas - pensemos, por exemplo, na expansão da cafeicultura paulista. Pelo contrário, ocorreria "de fora para dentro", privada da terra seu papel produtivo e assumido unicamente o papel de "reserva de valor" e meio de acesso a outras formas de riqueza" associadas à propriedade (ibid.: 117), garantida mediante lotação com pecuária.

A transformação da terra em "reserva de valor" é argumentada pelo autor enumerando alguns exemplos, como a captação de investimentos do Centro-Sul do país, inflação e a preocupação com a preservação de recursos por parte de empresas multinacionais na Amazônia (ibid:: 117). Ordenação na qual enxergamos a reprodução de mecanismos de regulação de investimentos de capital no território nacionalmente constituído (e para além dele) centralizados pelo Estado no fomento de determinados conglomerados empresariais. Daí Graziano veicular a fronteira ao "modelo agrícola" brasileiro (ibid.: 118), algo que pode conduzi-lo a valer-se do território como dado, visto que esse "modelo" parece sempre existir. Outra observação é que tomar a terra como "reserva de valor" seria um contrassenso à crítica do valor em Marx, pois abdica do valor como relação produzida na exploração de trabalho.

O desaparecimento da fronteira levaria a uma série de consequências relativas ao desenvolvimento agrícola do Brasil, fracionadas pelo autor nos planos social, econômico e político (ibid:: 118). No social, a fronteira representa "o locus da recriação da produção camponesa expulsa das regiões de agricultura mais desenvolvida" e, uma vez fechada, induziria à multiplicação de pequenos fluxos migratórios sem rumo, perambulando por todo o país. Pelo viés econômico, a regulação do preço dos alimentos consumidos pela classe trabalhadora com a produção na fronteira deveria ser compensado, com o fechamento, com a importação desses alimentos ou no tabelamento de seus preços. Por fim, politicamente, a feição de "válvula de escape" própria da fronteira deixa de vigorar com o fim desta. Desse modo, ao se fechar, a fronteira se torna o local do conflito pela posse da terra (ibid.: 118-9).

Indicadores do fechamento são inventariados pelo autor: primeiramente, há a própria flagrância do conflito, deslocado do Centro-Sul para a Amazônia. Em seguida é comentada a regularização da propriedade, que leva à expropriação dos posseiros por essa via "legal" ou por "acordos" e violência física (ibid.: 119). Os títulos provenientes da regulação são expedidos privilegiadamente em proveito dos proprietários "recém-chegados à região" (ibid.: 
120), o que favorece a concentração fundiária. Ainda, nosso interlocutor atesta na evolução do uso do solo amazônico, entre 1972 e 1976, um crescimento das áreas extrativas em relação às de lavoura e pecuária, algo que, para ele, demonstra uma apropriação cabal da terra como reserva de valor (ibid:: 121), e a condição de reserva de valor leva à especulação com o preço da terra, movimentando o mercado. O último indicador seria a denominada "urbanização precoce das cidades" (ibid.: 122), destino dos lavradores expropriados pelos procedimentos especulativos em torno da base fundiária.

Graziano procura avaliar que consequências podem ser deflagradas do fechamento da fronteira, interno à própria Amazônia e relativo ao Centro-Sul e ao Brasil. Internamente, entre os empresários se coloca o problema de como converter em dinheiro a condição de "reserva de valor" atribuída a terra. O problema é respondido com o próprio recebimento de incentivos fiscais, mas também com a possibilidade de se lotear as terras e vender suas parcelas a preços altos, se bem que nem todos possam recorrer a tal tática; caso contrário, os preços seriam rebaixados (ibid:: 123). Quanto ao Centro-Sul, fica a questão de para onde dirigir o excedente populacional espoliado na agricultura, bem como em que situação passa a se encontrar a ocupação de terras ali inexploradas (ibid.: 124). E se à inexistência de terras a serem ocupadas equivale a intensificação do investimento de capital na agricultura, o autor coloca que o incremento da produtividade do trabalho e da terra decorrente da aplicação capitalista se restringiria a algumas regiões e produtos, e tendencialmente em favor dos interesses de grandes grupos monopolísticos ${ }^{64}$ (ibid.: 124).

Pelo próprio caráter do desenvolvimento da produtividade do trabalho e da terra na agricultura brasileira - para empregarmos os termos do interlocutor -, o "fechamento" da fronteira na margem esquerda do Baixo Amazonas talvez nem sempre mobilize os mesmos elementos elencados para a Amazônia em geral. Tal sentença também poderia ser reformulada perguntando em que sentido ocorre transformações, nas relações de produção, no contexto nacional de modernização da agricultura. Deixamos em aberto se um elemento como a precificação da terra engendra um possível fechamento da fronteira, comandando a operação do mercado fundiário e certa concentração, reafirmada na criação de gado. Nesse caso, a precificação se adianta à ocupação enquanto forma, isto é, subjaz à atuação dos lavradores

\footnotetext{
${ }^{64}$ “Como já dissemos anteriormente, a não existência de terras livres na fronteira obriga que, para responder ao crescimento da demanda de alimentos e matérias-primas, a agricultura se capitalize de modo a aumentar simultaneamente a produtividade do trabalho e a produtividade da terra [...] Mas, certamente, esses aumentos de produtividade continuarão restritos a certas regiões e produtos [...] Assim, a 'modernização dolorosa' porque é lenta e restrita - continuará o seu caminho, acompanhada por uma presença cada vez maior de capitais monopolistas" (Graziano da Silva, 1982: 124).
} 
que a base fundiária é mercadoria adquirida no mercado pela compra, juridificada pela titulação - mesmo que na promessa - e objeto de concentração dos meios de produção. Simultaneamente ao funcionamento de um mercado segundo a estipulação de preços para a terra, assim, permaneceria viável o apossamento de "terras livres" no interior da floresta.

Em contrapartida, aspectos outrora sumariados quanto ao "fechamento" da fronteira, na conjuntura que pesquisamos, não aconteceriam "de fora para dentro", como colocado por Graziano, bem vista a figura de Paulino. Sequer verificamos, na área, qualquer grande projeto de incentivo fiscal, como talvez deflagrado para o restante do vale amazônico, o que enseja a problematização de porque, ali, tal política de fomento jamais ter vigorado. As ponderações servem para relativizar o grau de abstração com que lida Graziano e pontuar determinada precipitação existente em suas conclusões. Mas para que discutamos a realização dessas políticas e sua relação com a dinâmica da fronteira, precisaríamos voltar à instituição do Estado racionalizando o investimento capitalista e sua vinculação com as particularidades regionais - o que esboçaremos no cap. 3.3.

\subsubsection{O patrimônio do Limão e a urbanização na fronteira}

Resgatando as entrevistas com Bia e com Imá no Limão (cap. 2.2), observamos que é o Estado que esquadrinha o perímetro do patrimônio, por intermédio de Wilson. Corolário disso é a separação física da comunidade entre a rua, onde fica o comércio, e o centro, onde se trabalha. Doravante os lavradores passam a contar com uma casa em cada um desses locais.

Tanto Bia e Imá quanto Dona Celi descrevem algumas das primeiras edificações do Limão. Havia ali um barracão de palha, destinado a acolher os recém-chegados de Ourém. A função de alojamento, pois, permanece útil enquanto os roçados estão em fase de constituição, aproveitando-se a madeira derrubada na construção das residências. Uma vez assentado um número, digamos, suficiente de lavradores, o barracão deixa de existir. Logo com a vinda das primeiras famílias, é também erguida uma igreja, posteriormente sendo congregada, em torno dela, escola e posto de saúde. Com a abertura da PA-254, a centralidade constituída em torno da igreja se desloca para a beira da estrada, de onde vão surgir comércios.

Também recordemos que, para O. Velho ${ }^{65}$ (1979: 201), a penetração de agrupamentos para o interior da mata, cada vez mais longínqua dos rios principais, anunciava um novo padrão de ocupação da terra na Amazônia. Ele descreve que, buscando um local favorável para estabelecimento, em geral os indivíduos em excursão escolhiam um sítio de solo argiloso

\footnotetext{
${ }^{65}$ Ele disserta sobre os mesmos temas em Velho (1981: 200-3).
} 
próximo a um igarapé, ideal para o plantio e como material de construção, para daí trazerem suas famílias (ibid.: 201). Em caso de distâncias próximas entre as casas e a depender da qualidade do terreno, formavam-se comunidades rurais, que funcionavam segundo um corpo de regras costumeiras, estabelecido entre os moradores (ibid.: 202).

No firmamento das comunidades contribui especialmente a construção das estradas e ramais, que poderiam "tornar-se o locus para a comercialização inicial dos produtos agrícolas da área" (ibid.: 202). Seguidamente, "outros camponeses que estavam nas matas próximas podiam por vezes vir residir no agrupamento", e "quando a comunidade se tornava capaz de oferecer algum tipo de instrução rudimentar para as crianças, um novo e poderoso fator polarizador surgia", deslocando para lá famílias, ou pelo menos as crianças (ibid.: 202). Devido à dilatação desses grupamentos, não raro o terreno de alguma família se localizaria algo distante de sua residência, de sorte que "essa separação entre local de residência e local de trabalho tornou-se mais frequente à medida que chegavam novos migrantes e a terra disponível já estava mais longe" (ibid.: 202). E se acrescemos a viabilidade de compra das terras já ocupadas nas proximidades do povoado, alguns moradores passam a se deslocar para pontos cada vez mais isolados. Deslocamento, de acordo com Velho (ibid.: 203), sustentado na crença da existência de solos mais férteis nas porções mais distantes dos grandes rios, o que baliza a expansão da fronteira pari passu à estagnação ou diminuição da população dos agrupamentos.

A propósito, quando construída a PA-254, mais indivíduos se concentram no Limão. Algumas narrativas ponderam a evolução da comunidade: Imá diz que na rua havia um igarapé de uso comum, aproveitado no abastecimento das residências, na pesca e para lavar roupas, encontrando-se hoje praticamente seco (Fig. 5). Já em uma conversa com Ceará, ele descreve uma rua ao entardecer do dia em que chegara à comunidade, em meados da década de 1980, com fraca iluminação pública, comércios em funcionamento, casas, campo de futebol, uma cachoeira represada (que antes escoava no igarapé) e uma madeireira, onde primeiramente trabalhou. A iluminação, no caso, era fornecida por um gerador a diesel, que funcionava das $18 \mathrm{~h}$ às $21 \mathrm{~h}$.

Com o crescimento, patentemente vem o mencionado distanciamento entre o centro e a rua. Esta última é lotada por efeito dos serviços oferecidos, o que nos leva a ponderar acerca de alguma ampliação do afresco de necessidades de consumo internalizadas pelos lavradores. Mesmo pertinente o estabelecimento no centro, as famílias por vezes admitiam um recémchegado para servir de meeiro em suas terras, alternando com ele os dias de trabalho; ou 
então, pai e filhos mais velhos roçavam durante a semana e se debandavam para o agrupamento no sábado ${ }^{66}$.

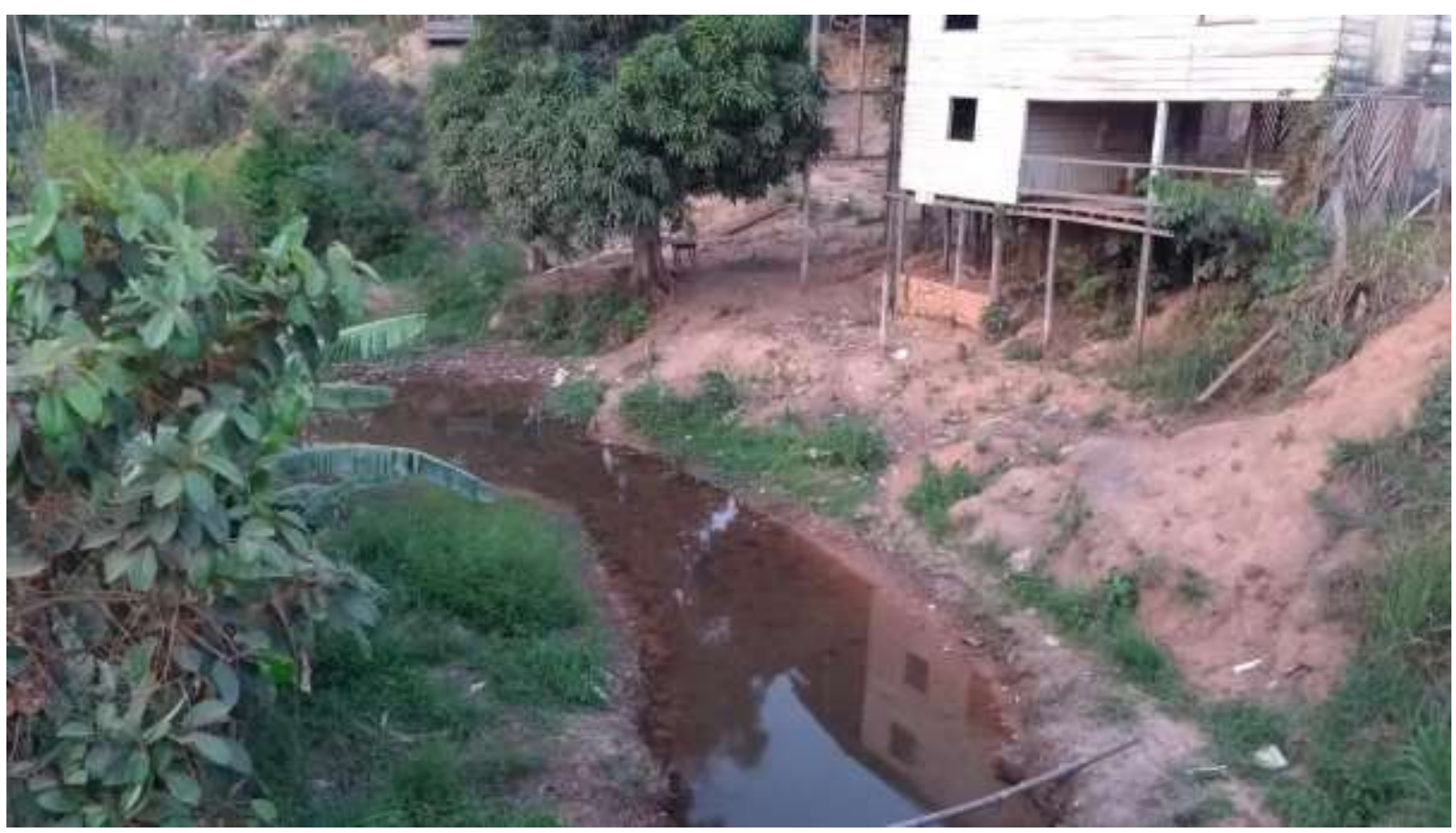

Fig. 5. O igarapé do Limão, hoje praticamente seco.

Como Velho, num artigo compilado em sua Geopolítica da Amazônia, Bertha Becker consagra uma hipótese para o que chama de "fenômeno urbano na fronteira" (1982, cap. 5). Respaldada em Harvey, ela interpreta como as cidades "são construções geradas pela mobilização, extração e concentração geográfica" do excedente social, referida aos povoados de fronteira nas encostas da Belém-Brasília (ibid.: 110). Povoados ditos de "caráter ruralurbano", porquanto servem de residência para trabalhadores do campo e compõem pequenos centros de mercado, embora sem a complexidade social que julga necessária para sua classificação como centro urbano (ibid.: 111). Daí a autora os situar como forma incipiente da mobilização do excedente social.

\footnotetext{
${ }^{66}$ Velho (1979: 203) retrata o mesmo em sua pesquisa: "Quando podiam, os ocupantes mais antigos colocavam alguém em suas terras - em geral um recém-chegado - e ficavam alternando. Ou então o chefe de família podia ficar na terra (por vezes com algum filho mais velho), mantendo o resto da família no povoado para onde se deslocava nos fins de semana". Sobre a oposição rua x centro, a explicação de Velho (1980: 102) difere do que observamos em campo. Para ele, a prescrição de um novo padrão de ocupação territorial localizado na terra firme (centro, aqui empregado numa acepção diversa da nossa), provoca "o aparecimento de um elemento de perturbação"; elemento relativo ao povoamento da beira dos rios, a saber, "o desenvolvimento, a partir de alguns centros [terra firme], de aglomerados maiores, por vezes chamados de rua. Deixam de ser um simples centro quando o seu crescimento exige que as roças sejam deslocadas mais para longe; seguidas, depois, pelos currais dos animais". Parece que, no autor, "rua" se refere a um centro urbano que cresce até, ocasionalmente, emancipar-se como município.
} 
Estes povoados surgiriam como pontos de concentração de força de trabalho na abertura de áreas, produzindo excedente mediante apropriação da terra e exportação de gêneros agroflorestais, entre os quais alimentos baratos para abastecimento dos trabalhadores citadinos. Surgiriam igualmente como centros de mercado e pontos de apoio à circulação, por exemplo, em torno de restaurantes e postos de gasolina de beira de estrada (ibid:: 116). Nesse sentido, o povoado retém e circula excedente em "âmbito local" e o mobiliza para além de seus limites: nele se instala os cultivadores avizinhados em busca de bens e serviços, tal como se comercializa a pequena produção enviada para a cidade; para além dele, as "classes mais ricas" consumiriam produtos exportados mais onerosos, como gado e madeira (ibid.: 116).

Becker prossegue advertindo que a variedade de funções ofertadas nos povoados explica seu tamanho, se bem que não fatalmente a povoados maiores corresponda maior nível de subsistência da população, ou maior "hierarquia" (ibid.: 117). Inclusive, a acessibilidade a equipamentos urbanos pode conduzir à concentração em determinados povoados e à extinção de outros, também sujeitos a mudanças em dimensão em consequência da expansão da empresa agropastoril, provocando a evasão de posseiros; no caso, sobretudo no trecho da rodovia próximo a Paragominas. Portanto, um povoado parece subsistir enquanto necessita concentrar trabalhadores na abertura de novas áreas, como conclui:

Assim, parece que, uma vez exercido o seu papel de concentrar mão-de-obra com o objetivo de desbravar a área para os grandes proprietários, o povoado se torna desnecessário, extinguindo-se e reaparecendo em novas áreas que estão sendo abertas (ibid.: 119-22).

Distinguimos que o Limão se origina, como povoado de fronteira, enquanto ponto de concentração da força de trabalho. A mobilização dos lavradores de Ourém converge, com o empréstimo cedido pelo armazém, para a abertura de uma nova área, mas como processo que passa às costas das personas envolvidas. Assim, como mencionado por Becker (1982: 116), a reprodução do excedente ocorre pela apropriação da terra na floresta e venda da produção agroextrativista no comércio.

Consideramos que, com a evolução da comunidade, se constitui em torno da rua um centro de mercado, e se concentram equipamentos de transformação industrial, como casas de farinha, e de uso coletivo, como escolas e igrejas, acompanhando o incremento populacional. Esse crescimento também se deve - ou se deve sobremaneira - à interposição organizada do Estado, em função da PA-254 e da importância da rodovia na circulação da produção. Talvez por isso, se surgem mais povoados mobilizando trabalho na apropriação da terra, por outro 
lado a formação da rua e os serviços existentes no Limão marcam sua posição como distrito municipal de importância nos arredores, embora com dimensões relativamente reduzidas ${ }^{67}$. Dessa forma, a rua materializa as condições gerais de produção na área, nas quais se inserem dinâmicas de aparecimento e desaparecimento de agrupamentos em tarefas de abertura de novas áreas; ao menos, até uma época recente (cf. cap. 4.1).

\subsection{Monetarização e diversificação das relações de trabalho na fronteira}

O Sr. Koji Ueno, radicado em Monte Alegre desde 1931 e morto em 2009, publica em 2005 suas memórias, intituladas História de minha vida. Entre outros eventos, relata a partir de sua experiência pessoal como se organizara a colonização na área no pós-II Guerra (Ueno, 2005). Integrando o primeiro grupo de japoneses chegado à Amazônia, ele informa que durante tal guerra apenas sua família e de mais três companheiros imigrantes continuava instalada no município (ibid:: 15). Na época, os colonos introduziram duas culturas inéditas na Amazônia: a juta ${ }^{68}$ e a pimenta-do-reino, até então importadas da Índia (ibid.: 15).

Na década de 1950, Ueno conhece Kotaro Tsuji, fundador de uma empresa interessada no cultivo da juta e na subvenção da imigração destinada à colonização agrícola. A empresa fecha um contrato com o governo brasileiro para a vinda de cinco mil colonos para o país, e

\footnotetext{
${ }^{67}$ Imá nos informa que, no âmbito da administração pública, o Limão foi emancipado à condição de distrito de Monte Alegre na década de 1990, e arrisca que o local contém pouco mais de quinhentas famílias, com um crescimento populacional historicamente constante.

${ }^{68}$ Alguns de nossos interlocutores, que já viveram nas áreas de várzea e cultivaram juta, explicam como funcionava a produção: a família semeava a erva no início do período de chuvas, para colhê-la ao fim da estação (cerca de cinco meses depois, em maio). A preparação da fibra era extenuante, mas era comum que contasse com contratação de diaristas. Nela, o produtor, inundado até sua cintura aproximadamente, cortava com um facão a base do vegetal - não raro, contraíam aí pneumonia ou tuberculose. Os talos extraídos eram lavados com água corrente e depois deixados de molho, para soltarem suas fibras, que então eram amarradas com cordas e vendidas, para um "regatão" atravessador ou para o comerciante que lhe aviou. Janete Gentil (1983), em sua dissertação, descreve o funcionamento da produção de juta nas várzeas do Baixo Amazonas segundo "relações socioeconômicas capazes de retratar a realidade espacial da várzea enquanto espaço agrícola" (ibid.: 6). Ela explica, a partir da observação empírica, que em geral a juta era repassada a preços módicos para um intermediário, quase nada restando de saldo ao produtor. Esta sobra era expendida na compra de artigos manufaturados, como o arroz descascado, o açúcar, o café, o sabão e o querosene (ibid: 117). Ainda, coloca que o jutal integrava a unidade familiar varzeira, localizado ao lado do quintal de onde germinava as "fruteiras". Aí atrás, o varzeiro edificava sua barraca, de madeira ou palha e coberta de barro, palha ou cavaco, com um canteiro traseiro suspenso, o jirau, onde a família mantinha alguns temperos e ervas medicinais. Paralelo ao rio, lavravam a roça, oposta ao curral suspenso, denominado de "caiçara", com função de abrigar o gado nos períodos de cheia; nos períodos de vazante, o gado pastava em campos, de uso comum, perfilados por pequenos lagos que lhes servia de bebedouro (ibid.: 118-9). Diga-se de passagem, "caiçara" é o termo empregado pela autora na designação dos currais suspensos em Santarém. Em muitas áreas da Amazônia, incluindo Monte Alegre, eles são conhecidos como "marombas", confeccionados a partir de troncos arrastados pela enxurrada dos rios, dispostos em intervalo e paralelamente, presos uns aos outros através de cordas. Notamos, pelas descrições sumariadas, a reprodução de determinadas relações de trabalho que, por nossa parte, será investigada a partir das áreas de fronteira na terra firme.
} 
Ueno é convidado a ajudar como intérprete (ibid.: 16). A coordenação da tarefa de recebimento dos imigrantes fica a cargo do instituto nacional de colonização, por meio da Colônia Agrícola Nacional do Pará (Canp), gleba planejada e administrada pelo Estado localizada a noroeste da cidade. Tsuji, o administrador da Canp e Ueno decidem estruturar em Açaizal, próximo à Mulata, o núcleo de recebimento dos imigrantes, pensando na ocupação dos terrenos circundantes, de solo apropriado para culturas permanentes (ibid.: 16) (Fig. 6). Como as verbas destinadas para a edificação do núcleo atrasam, Tsuji assume as despesas, e em setembro de 1953 ali desembarca as primeiras famílias trazidas do Japão.

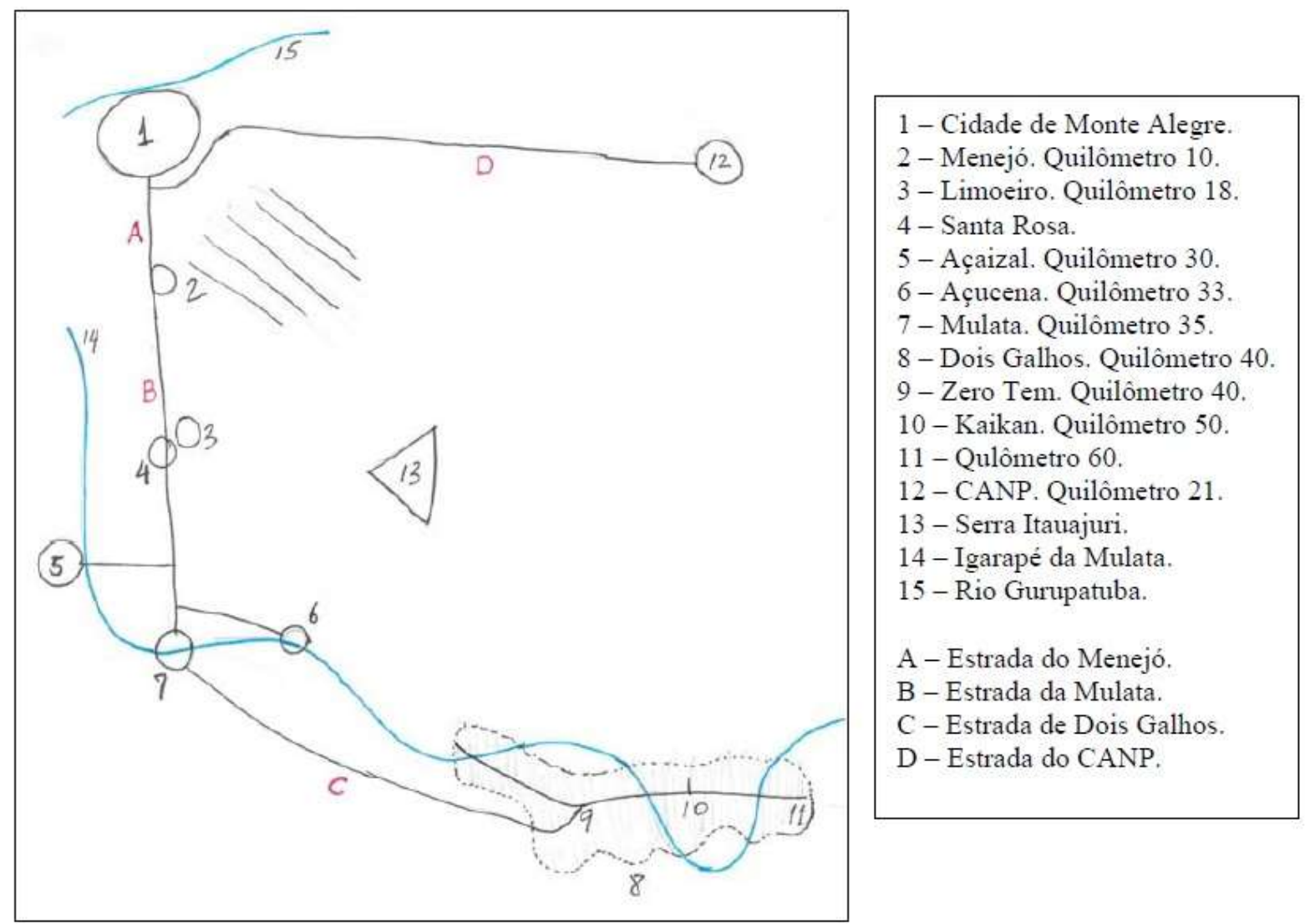

Fig. 6. Mapa mental de Koji Ueno, localizando os primeiros projetos japoneses de colonização em Monte Alegre. Fonte: Ishizu (2007: 106).

Segundo a dissertação de Tatsuo Ishizu (2007: 89-90), que examina historicamente a colonização japonesa em Monte Alegre, no intervalo 1953-1955 chega ao município 126 famílias (810 indivíduos), instaladas em Açaizal. Famílias que, mais tarde, fundariam Dois Galhos, beirando uma estrada construída a partir da gleba Mulata em direção nordeste. Assim como Ueno, Ishizu especifica que a Canp era a incumbida da preparação das condições de recebimento dos imigrantes, a dizer, da abertura da estrada, da demarcação dos lotes e da 
derrubada inicial da floresta, também erguendo um alojamento provisório, com palha de palmeira, aí improvisando um refeitório e uma escola ${ }^{69}$ (ibid.: 94). Quando, porém, chegam os povoadores, eles precisam não só construir suas casas e cavar seus próprios poços, como igualmente abrir a estrada inacabada por cerca de $20 \mathrm{~km}$, de Mulata até Dois Galhos, e lotear seus terrenos (ibid.: 95).

Nesse sentido, os imigrantes organizam o emprego conjunto de força de trabalho tal como expomos para outras situações, na abertura de áreas e na formação de roçados. Seu Ueno escreve que, depois de queimada a mata, os terrenos são loteados e distribuídos por sorteio, para logo serem ocupados para a semeadura de milho (Ueno, 2005: 17). Os lavradores lotam 1500 sacas, cuja comercialização fica a cargo da Companhia Tsuji. O autor relata a experiência com o negócio como desastrosa, uma vez que despacha o milho não em nome da empresa, mas dos produtores, visando à redução de impostos interestaduais. Mas o pagamento demora a chegar, e ele precisa tomar emprestado dinheiro no comércio para indenizar seus companheiros (ibid.: 18). Por obra de problemas como esse, poucos anos depois os japoneses resolvem fundar uma cooperativa.

Mesmo que fragilizados os mecanismos de monopólio da circulação para extração de excedente por parte do comerciante, tomar emprestado dinheiro do comércio atesta para o mesmo que posição na reprodução das relações de produção na área? Podemos dizer que a intermediação duma companhia comercial como a Tsuji concorre, digamos assim, na quebra das relações mercantis anteriores? Com a comercialização de produtos agrícolas através da empresa, o dinheiro pode ter, em algum grau, a função necessária de "meio de circulação" das mercadorias (Marx, 1. I t. I, 1985, cap. III item 2)? Aqui, o dinheiro segue seu curso como pressuposto e resultado do processo social de troca. E tanto mais se temos em conta, doravante, o funcionamento de uma cooperativa de agricultores - nessa época restrita a japoneses - que negocia diretamente com consumidores portadores de dinheiro.

Marx apresenta a função do dinheiro como meio de circulação partindo do processo de troca, no qual uma determinada mercadoria, no nosso caso, milho, muda de sua forma corpórea para sua forma de valor, ou dinheiro. O valor da mercadoria milho se realiza quando esta é vendida, metamorfoseada em dinheiro. Simultaneamente à venda, o dinheiro que possui

\footnotetext{
${ }^{69} \mathrm{O}$ autor reproduz um trecho do diário escrito por sua mãe sobre a chegada das famílias a Açaizal: "Quando chegamos, as famílias foram alojadas no alojamento provisório de Açaizal, uma vila de casas construídas com folhas de palmeiras. Como a parede que separava com o vizinho também era de folha de palmeira, podíamos ver e ouvir o que se passava do outro lado. Como precisávamos providenciar o local para dormir, fomos à mata, cortamos a madeira, construímos um assoalho em uma parte, então ela ficou de uma forma que parecia com o quarto. Como no fundo tinha um igarapé, dela retiramos a argila, e usando este material e pedras, construímos o kamado [fogão a lenha] para cozinhar" (Ishizu, Fumiko, 1955: 73 apud Ishizu, Tatsuo, 2007: 95).
} 
o comprador muda de forma, de dinheiro para mercadoria milho. Por isso, "a transformação de mercadoria em dinheiro é, ao mesmo tempo, transformação de dinheiro em mercadoria [...] Ou venda é compra" (ibid.: 96), de maneira que o processo social de mudança de forma das mercadorias se repõe continuamente. A última metamorfose de uma mercadoria é a primeira metamorfose de outra, como um ciclo que define o processo de circulação ${ }^{70}$ (ibid.: 98-9).

Digamos que o milho vendido pela cooperativa é trocado por dinheiro, que compra sal; o vendedor do sal agora possui dinheiro, com o qual compra sua aguardente; o vendedor de aguardente compra farinha; e por aí vai. Aqui o dinheiro, como meio de compra da parte de seu possuidor, se transfere para as mãos do vendedor, para ser novamente meio de compra de outra mercadoria, reiterando a forma monetária. O processo de circulação aparece, pois, como curso do dinheiro, ocultado daqui a mudança de forma das mercadorias ${ }^{71}$ (ibid: 101). O dinheiro subordina a seu automovimento os mais diferentes possuidores de mercadorias, e tal subordinação aparece como um processo social da circulação, no qual a riqueza abstratamente produzida é socializada. Apesar de tudo, a circulação de mercadorias na área não invalida que a família lavradora também se dedique à subsistência trabalhando em seu próprio lote de terra.

Retomando. A dissertação de Ishizu (2007: 106) descreve que a cooperativa é fundada em 1957 com o nome de Sociedade Cooperativa Agrícola Mista de Monte Alegre (Socama) (Fig. 7). Os interessados em associação deveriam entrar com determinada soma em dinheiro ou mercadoria necessária para constituir o capital inicial da entidade, que passa a centralizar a comercialização dos gêneros fornecidos por seus sócios. A sede busca de caminhão e transporta para a cidade a produção, enquanto os colonos adquirem, daquela, bens que não produzem e que julgam necessários para a satisfação de suas necessidades ${ }^{72}$ (ibid: : 106-7). Os associados começam produzindo pimenta-do-reino, e segundo Ueno (2005: 28), graças à qualidade do solo, a cultura de tal especiaria e a cooperativa se desenvolvem ${ }^{73}$.

\footnotetext{
70 "O ciclo descrito pela série de metamorfoses de cada mercadoria entrelaça-se portanto, inextricavelmente, com os ciclos de outras mercadorias. O processo em seu conjunto apresenta-se como circulação de mercadorias" (Marx, I. I t. I, 1985: 99).

71 "O resultado da circulação, substituição de uma mercadoria por outra mercadoria, aparece portanto intermediado não pela própria mudança de forma, porém pela função do dinheiro como meio circulante, o qual circula as mercadorias em si mesmas inertes, transferindo-as das mãos na qual elas são não-valores de uso para as mãos na qual elas são valores de uso, sempre em direção contrária ao seu próprio curso " (Marx, I. I t. I, 1985: 101).

${ }^{72}$ Ueno (2005: 28) informa que a cooperativa foi fundada por seus amigos Roberto Ishiguro, líder da Colônia Japonesa, e por Eduardo Uwamori. Sabemos que os nomes foram dados pelos brasileiros devido à dificuldade com o idioma japonês; assim, Roberto na verdade se chama Kumekiti, e Ostuki, a quem entrevistamos, Otiqui.

${ }^{73} \mathrm{Em}$ um documento do Incra sobre o qual falaremos mais adiante, encontramos que a cooperativa, no ano agrícola 1973/74, vende 71837 kg de pimenta-do-reino, gerando uma receita de $\operatorname{Cr} \$ 575$ 194, 34; era o gênero com maior escala de produção entre os cooperados, e o único que passava por procedimentos de classificação (Incra, 1975: s/p). Não dispomos de mais dados acerca da produção na área e no período analisado.
} 


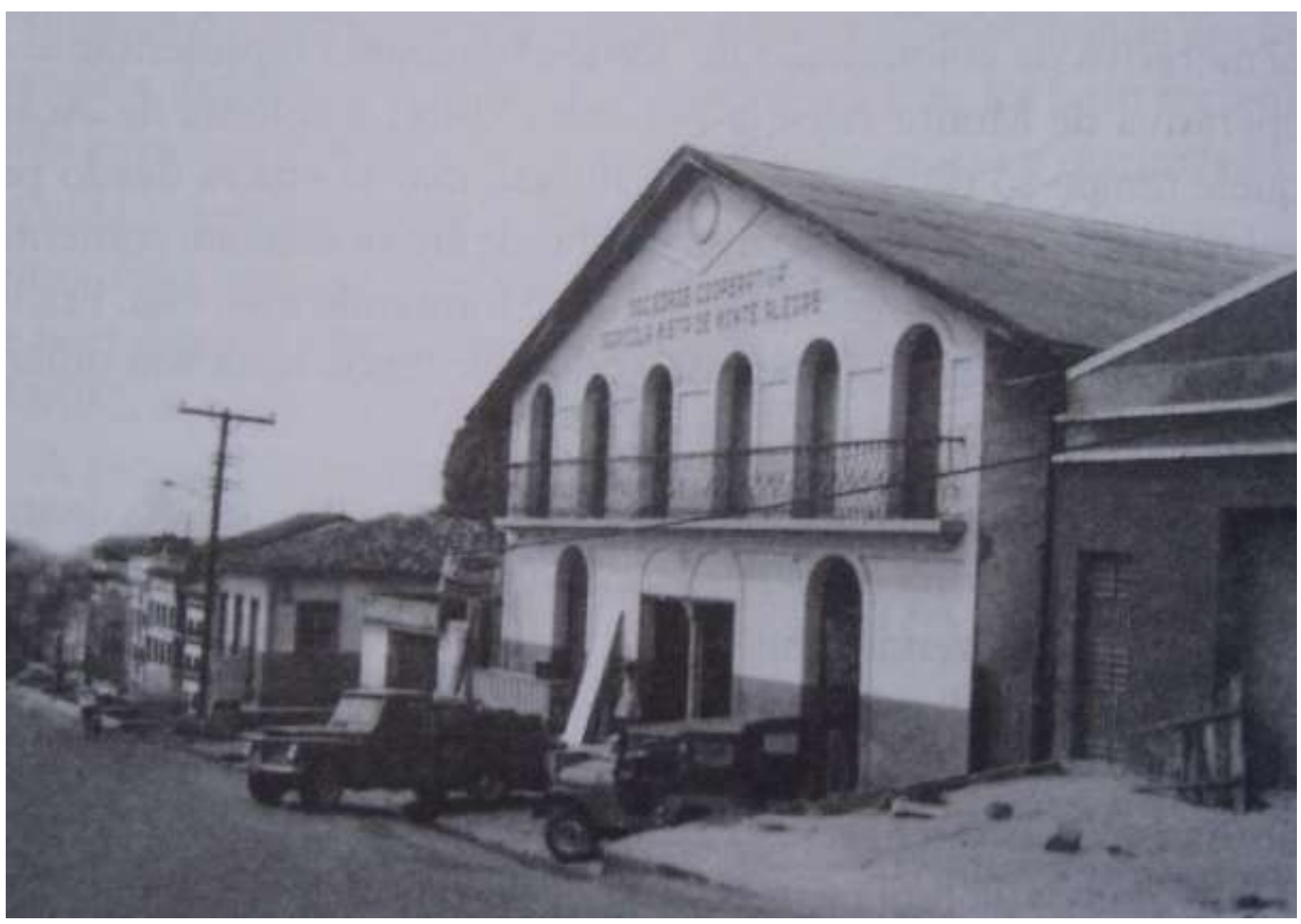

Fig. 7. Sede da Sociedade Cooperativa Agrícola Mista de Monte Alegre. S/d. Fonte: Ueno (2005: 28).

Ainda, consideremos a trajetória de Kazuo Takatani, chegado ao Brasil em 1955, aos oito anos de idade. Sua família veio financiada pela Companhia Tsuji para cultivar juta no Baixo Amazonas. Eles se instalaram primeiramente em Belterra, para depois seguirem para Monte Alegre, na comunidade do Açaizal, num ponto chamado Cachoeira. Ali, os imigrantes iam abrindo estrada com machado e demarcando terrenos até Dois Galhos, operando na retaguarda a prefeitura, com obras de manutenção. No decurso dos trabalhos, recorrentemente contraíam malária, e como lembra o entrevistado, frente à insalubridade dessa situação, à má qualidade das escolas, à falta de assistência e à distância e dificuldade de acesso ao mercado, muitas famílias evadiram dos projetos ${ }^{74}$. No caso dos Takatani, passaram para um terreno abandonado, logo entregue a um grupo de cearenses que reclamou a propriedade da parcela, alegando o registro da mesma junto ao governo. Regularização fundiária e procedimentos de expulsão, nesses termos, estão associados, principalmente - como vimos acontecer em outras situações (cf. caps. $2.2 ; 3.1$ ) - pela facilidade em requerer terras, ou então, a depender da

\footnotetext{
${ }^{74}$ Ishizu (2007: 111) relata que das 126 famílias trazidas naquela leva da década de 1950, mais da metade já havia abandonado a área em 1958, restando, em 1960, apenas 20 famílias. $O$ autor argumenta que não houve um motivo em especial para tal êxodo senão o próprio conjunto de fatores relativos ao isolamento, resumidos pelos nipônicos como fuben, isto é, "incômodo", "inconveniente".
} 
perspectiva, pela "frouxidão" na tarefa de loteamento pelo Estado. O interlocutor afirma, a respeito disso, que a empresa de colonização japonesa não comprava terrenos; os interessados simplesmente se dirigiam ao "Incra" e solicitavam um fiscal, que "pegava uma vara de dois metro e amarrava assim no terreno e dizia: 'olha, daqui pra cá é seu, daí pra lá é seu'”. Só muito tardiamente teriam sido expedidos títulos de posse.

O pai de Kazuo era militar em Nagasaki, e aprendeu a agricultar no Brasil observando seus vizinhos e amigos. A análise da situação de seu pai interessa, na medida em que vemos a passagem da profissão de militar, integralmente expropriado, para ser lavrador e poder parcialmente subsistir de seus meios de produção. Mas sublinhamos que o trato da terra não deixa de exigir disciplinamento e certo conhecimento, compondo um roteiro de mobilização da força de trabalho (Gaudemar, 1977), orientado pela liberdade do produtor pauperizado pela guerra. A família começa plantando batata e vai diversificando a produção, sobretudo com o firmamento de um contrato com a Tsuji para o fornecimento de sementes de juta. Passa a também produzir arroz, feijão, tabaco, gergelim e amendoim, embora as condições de vida só melhorem com a introdução do cultivo de frutos e hortaliças.

Quando sai de casa e adquire seu próprio terreno, Kazuo se presta sobretudo ao plantio de tomate, comprando a produção de seus vizinhos e exportando-a para Santarém e Manaus. Atua como um atravessador, assumindo no contexto o risco de perder os tomates por não conseguir vendê-los ${ }^{75}$. Posteriormente, ao ingressar na cooperativa, é designado diretor comercial, abrindo entreposto em Manaus. Não obstante, logo malogra nessa iniciativa por força da qualidade do fruto, tanto mais a contar do mau armazenamento e do transporte em lentas embarcações. Perante esse fracasso, sustenta-se a cooperativa, cada vez mais, do plantio de pimenta-do-reino.

Kazuo chega aos arredores do Limão comprando terras justamente com o objetivo de cultivar a especiaria, avançando de localidade próxima:

D.L.: E como é que o senhor chegou aqui pro Limão?

Kazuo: No Limão? É porque a gente morava antes de chegar no Limão. Aí o terra que a gente tinha, não era terra bom pra certas plantação, como pimentado-reino, né. E também [era] terra pequena. E aí foi comprando lá, sabe.

D.L.: Aí até chegar no Limão?

\footnotetext{
75 Disserta Kazuo: “Até os anos 70 não tinha quase mercado. Trazia dez caixa de tomate, doze caixa Às vezes [ficava] seis caixa sem vender. A gente nem recebia mais. Era assim, muito pequeno. Aqui Monte Alegre, quando conheci, tinha um caminhão só".
} 
Kazuo: É. Aí cheguei no Limão, comprei terreno ali no Água Branca. Ainda tenho dois terreno ali no Treze do Água Branca.

Dada sua trajetória, a disponibilidade de dinheiro para adquirir terras vem de sua função de atravessador e da participação na cooperativa? De qualquer modo, ser proprietário de dinheiro lhe possibilita ser proprietário de - e concentrar relativamente - terras. Na década de 1980, Kazuo chega a contar, apenas no Setor Dois e no Limão, nove lotes, somando 900 ha, ali cultivando pimenta-do-reino, tomate, urucum e mandioca. Para o trato de uma lavoura de tal magnitude, contava com a força de trabalho disponível no entorno, como relata:

D.L.: Como o senhor colhia tudo isso?

Kazuo: Tinha empreiteiro, tinha diarista. Aquele pessoal do Limão quase todo trabalhava pra japonesada, né. Era eu... mais ou menos umas cinco família atuava lá, né. Eu trabalhava com o pessoal lá; pimenta, tomate, produção de tomate. Por isso que hoje eles sabem plantar pimenta e tomate.

Em outro momento, retomamos:

D.L.: Quando o senhor chegou no Limão já tinha muita coisa lá?

Kazuo: Limão era nova ainda, né. Lá, parece que foi década de 60, né, parece. Vieram pessoal do Ceará, Nordeste. Entraram aí pra colonizar lá no Limão [...] Mas depois a gente entrou lá perto, começou a plantar pimenta, precisou de muita mão de obra. Usou muita mão de obra, desde criança, mulheres, tudo. Eu, quando tinha pimenta, tinha mais ou menos 120 pessoas trabalhando pra apanhar pimenta, durante dois ou quase três meses.

D.L.: A terra de lá foi comprada ou o senhor foi abrindo mata?

Kazuo: Eu já comprei. Tinha um brasileiro que já tava ali localizado, né. Aí comprei dele. Também ganhei terreno pelo Incra, ali perto do Limão também, né. Comprei a prestações.

A introdução de culturas e técnicas é contada como uma espécie de legado deixado para os brasileiros, que também passam a agricultar tomate e pimenta-do-reino. Mas parece que a principal novidade verificada no excerto é uma espécie de assalariamento intermitente na forma da diária e da empreita, com remuneração individualizada da força de trabalho. Trata-se de uma metamorfose das relações laborais, se em correspondência ao abastecimento das unidades familiares pelo armazém e ao trabalho cooperativo do puxirum. Kazuo chega a contratar mais de uma centena de lavradores das proximidades, por mais de dois meses ao ano. Os terrenos são comprados de outrem, e com a diferença de que as parcelas "ganhas" pelo Incra não são doações, mas aquisições a dinheiro e em prestações. Ao que parece, uma 
vez loteados os terrenos pela instituição, só seria possível obtê-los mediante compra, o que aponta para mudanças nas políticas territoriais de distribuição fundiária.

Se a mobilização da força de trabalho (Gaudemar, 1977) dos lavradores diaristas pode ser capitaneada pelos japoneses, é porque estes são proprietários de dinheiro dispendido na contratação intermitente e reinvestido, como capital, na expansão dos pimentais, na compra de caminhões, etc. ${ }^{76}$. Temos como hipótese que tal propriedade se deve a trajetórias pessoais de acumulação, uma vez que estes imigrantes chegam a Monte Alegre destituídos de dinheiro. Talvez a intermediação inicial da Tsuji - independentemente da força de atuação da companhia -, e mais tarde, da cooperativa, tenha de algum modo permitido aos japoneses acessar o equivalente geral num contexto em que este pouco circulava, para que se possa canalizar investimentos na produção de mercadorias agrícolas. Assim aconteceria com Kazuo, que era um atravessador da produção de tomates e gerente comercial da cooperativa? Por sua vez, Ueno (2005) acumula por reverter seus ganhos na aquisição de gado e terra na formação duma fazenda. No começo, esses proventos são oriundos do trabalho de agricultor:

Comecei a trabalhar como autônomo. O recurso conseguido com a $1^{\mathrm{a}}$ safra do plantio de fumo era o primeiro ganho como autônomo da minha vida, e foi aplicado na compra de 2 vacas e uma novilha (ibid.: 31 ).

Lavrador que se vê como "autônomo". A linguagem empregada pelo autor sugere que o trabalho é uma fonte independente de rendimentos em relação a um hipotético patrão que lhe exploraria; a reflexão, digamos assim, é post festum. De todo modo, Ueno aparece como um sujeito racional que planeja a aplicação dos rendimentos adquiridos de seu trabalho individual de plantador de tabaco - sem dúvida, uma cultura comercial - como um sujeito monetarizado (Kurz, 1992). Já ulteriormente, os proventos são derivados precisamente do trabalho assalariado na companhia de colonização, que possibilita o crescimento de seu rebanho e a compra de terras:

Após ter trabalhado 7 anos no Kaikyoren [companhia de colonização], tive de parar por motivo de saúde, mas ganhei uma boa indenização que também foi aplicada na compra de gado. Assim foi aumentando a minha pequena fazenda. Depois de conseguir um terreno no Santa Maria e mais um terreno na várzea, nosso gado aumentou mais rapidamente, com a graça de Deus (ibid.: 31).

\footnotetext{
${ }^{76}$ Segundo conversamos com Kazuo, a expansão do cultivo demanda a contratação de maior número de trabalhadores; a produção passava por procedimentos técnicos, reduzindo ligeiramente a exploração de trabalho vivo, unicamente na aplicação de alguns insumos e na utilização de tratores na aração dos terrenos.
} 
Esta é a relação tomada a partir dos contratantes de força de trabalho. Já entre os trabalhadores, temos no depoimento de Imá $^{77}$ uma síntese das relações entabuladas pela diária e pela "empeleita” (empreita) nas lavouras do Limão:

Imá: Quando vieram os japonês pra cá, daí pra frente era só pimental; daí eles sustentavam a vila. O povo trabalhava a semana. Quando era no sábado, fazia o pagamento. O povo pegava já o que tinha e pagava o comércio [em] que comprava, né, pra manutenção da casa.

D.L.: Os japoneses é que pagavam as diárias?

Imá: Pagavam, voltava a trabalhar a semana de novo, e todo final de semana tinha aquele dinheirinho. Mas só dava pra pagar o comércio.

A questão que fica é: em que sentido as relações de trabalho, na comunidade, passam a ser organizadas pelo pimental e pelo dinheiro com que se remunera a diária, a despeito das relações mobilizadas pelo armazém? Ao menos quanto a Imá, o soldo é semanal e serve apenas para quitar os défices com o comércio, de acordo com as compras que fazia. Resta sondar se a ligação com o comércio é restrita à compra e venda de mercadorias a dinheiro, não obstante o pagamento efetuado - ou melhor, se efetuado - com um curto lapso temporal. É possível dizer que o empréstimo que caracteriza essa vinculação com o comércio na rua, no próprio Limão, subsiste porque só semanalmente o lavrador adquire dinheiro. Mas a relação difere de uma situação na qual o dinheiro seria obtido todo de uma vez, no período da colheita, com o ajuste de contas no armazém, e no qual o cálculo dos proventos depende do comerciante. No caso em questão, o dono de barracão poderia ainda reservar, para si, o poder de vender ou não fiado, e a quem ele a princípio desejar. A menos que possa comprar à vista, o produtor depende da relação quando não tem dinheiro em mãos; já tê-lo, confere a seu proprietário a liberdade de entesourá-lo ou desembolsá-lo onde quiser. Liberdade que figura na própria relação temporária entre patrão e empregado:

D.L.: O senhor tinha algum patrão assim, pra quem trabalhava mais?

Imá: Não. Só faz empreita pra um, empreita pra outro, trabalha diária pra um, diária pra outro, trabalha no meio. Aqui é difícil trabalhar pra um só.

Podemos arriscar que os pagamentos parecem realizados devido às relações vicinais de reconhecimento mútuo (cap. 2; Araújo, 1996)? Segundo o que conversamos com outros lavradores, o comerciante não cobrava juros, e o endividado poderia deixar de pagar seu

\footnotetext{
${ }^{77}$ Diz também Seu Bia: “Os japoneses, tem muita coisa eles. Dava muito ganho pro pessoal, não era? Uns pimentalzão. $O$ pessoal começou a trabalhar com ele pra diária, com empeleita. Tinha muito serviço naquele tempo dos japonês [...] Eles pagavam bem".
} 
passivo recorrendo com seu dinheiro a outros comerciantes, mas isso certamente lhe acarretaria empecilhos na comunidade. De todo jeito, se o dinheiro aparece como liberdade perante a coerção pessoal do patrão, representa cada vez mais plenamente o desenvolvimento da relação de valor, nele refletindo os caracteres sociais dos distintos trabalhos privados como trabalho humano geral (Marx, 1. I t. I, 1985, cap. I). Dessa maneira, passar pela remuneração do trabalho em dinheiro nos pimentais serve-nos para suscitar um problema mais amplo. Quer dizer: o da importância entrementes inequívoca do dinheiro como necessidade objetivamente posta entre os agentes exibidos; necessidade que engendra mudanças nas relações de trabalho.

E a trajetória de Miguel expressa muitas dessas mudanças. Ele é um lavrador de 49 anos que reside na Canp e mantém um centro, na comunidade da Linha do Ererê, pertencente a seu pai, que possui o título de compra e venda do terreno, mas não o título de propriedade.

Ao ser entrevistado, relata que certa vez, cortando mato em seu lote, uma árvore cai em sua cabeça, o que lhe acarreta problemas de memória e debilitação dos movimentos dos membros esquerdos. $\mathrm{O}$ acidente, obviamente, repercute prejudicando em grande medida $\mathrm{o}$ desempenho das atividades no roçado. Ele é o mais velho entre seis filhos, e aos 19 anos sai de casa para trabalhar nos garimpos de Laranjal do Jari (AP). Aos 23, ingressa na Jari Florestal como carpinteiro, "torando madeira no meio do mato" por quatro anos e pouco se deslocando para a cidade - inclusive, é quando se acidenta pela primeira vez com a queda de uma árvore e quando um tiro escapa de sua espingarda e lhe atinge uma das mãos. Aos fins de semana, ajuda seus colegas numa oficina da empresa, o que lhe permite aprender a consertar motos e a fabricar parafusos, angariando uma vaga de torneiro mecânico, que ocupa por mais quatro anos. A seleção para o posto é por ele destacada como baseada num teste prático, e não num currículo ${ }^{78}$, que pode ocorrer por ocasião da própria contingência de emprego de trabalhadores pela Jari Florestal. Significa que a força de trabalho empregada na empresa é altamente volante, como nos sugere a brochura de Garrido Filha (1980) sobre a empresa. Parece que, em muitas ocasiões, ao passo que mantém seu roçado, um lavrador resolve, intermitentemente, disponibilizar sua força de trabalho no mercado. A mobilização da força de trabalho (Gaudemar, 1977) é diversificada: no caso, Miguel é ora garimpeiro, ora lavrador, ora torneiro. Mas por que motivo ele se presta à submissão ao mercado ${ }^{79}$ ?

\footnotetext{
${ }^{78}$ Diz Miguel: “Aí eu comecei a trabalhar de oficina. Ajudava eles. Comecei a trabalhar de final de semana. Aí eu ia fazer parafuso. la lá, foi aprendendo aquilo ali, né, a época que surgiu uma vaga pra torneiro. Naquela época não tinha que ti fazer curso. Naquela época era por teste, né. Aí fui fazer um teste que era montar umas porta de ferro, que era pra emparafusar, gradear; era a minha profissão".

${ }^{79}$ Fazemos referência à pergunta norteadora da obra de Gaudemar, trazendo-a para nosso contexto: "por que razão se presta o trabalho, ou antes, a força de trabalho dos homens, a todas as variações de duração,
} 
Ao retornar a Monte Alegre, Miguel se casa e vai morar em terras doadas pelo sogro na comunidade do Açaizal. Nesta fase, passa por adversidades - sua filha adoece, ele atira acidentalmente no filho durante uma caçada e sua casa é incendiada - que, segundo o próprio, o faz decidir retornar à Canp. Com o dinheiro ganho na venda duma vaca, adquire o terreno onde se localiza sua residência, primeiramente de palha. Trabalhando como diarista, compra tijolos e edifica uma nova casa, enquanto lavra a terra, até hoje, com esposa e filhos.

Podemos denotar que acompanha a disseminação da compra e venda de diárias entre os próprios lavradores a diferenciação no padrão de consumo de bens adquiridos a dinheiro. $\mathrm{O}$ terreno da residência, separado da roça, é comprado com o dinheiro obtido da venda de uma vaca, atestando preços reduzidos para a terra na época. Outrossim, se inicialmente a casa é de palha - que pode ser apanhada de matas e capoeiras -, é então substituída por tijolos, não fabricados domesticamente, mas comprados no comércio ou em olarias. Mesmo produzir na terra demanda dinheiro, na contratação de diaristas, na mecanização, na compra de insumos, etc., em suma, no investimento de capital na terra, para adiantarmos um tópico discutido no próximo capítulo. Aqui, caso retomemos as premissas de Martins (1975), é no mínimo difícil discernir subsistência de excedente. Retomemos também que são novas formas de mobilização do trabalho, que se instalam a despeito da organização coletiva do puxirum. Elas não excluem o produtor e sua família da possibilidade de se reproduzirem, em partes, cultivando a terra e se apropriando de condições preexistentes na floresta e nos rios. No entanto, cada vez mais parece que, com determinada monetarização das relações de produção, não possuir dinheiro representa um grande infortúnio. É como coloca Miguel:

Pois é. Aqui mesmo nós não tem mais produção. Aí por falta de que? Por falta de dinheiro. O que que falta aqui pra nós? Nessa área aqui de terra, vai daí até bem aí assim pra lá, uns bom pedaço aí, muito boa pra mecanizar. Mas a gente não tem... eu não tenho condição. Essa área daqui assim, ó.

Um breve escrito de A. U. de Oliveira (1991), que identifica "questões teóricas da agricultura camponesa", imputa à vulgarização das diárias a incógnita do assalariamento no campo. A justificativa é de que esse regime de contratação, assim como a ajuda mútua e a parceria, "garantem a complexidade das relações na produção camponesa [...] primeira e fundamentalmente articulada a partir da família, a partir da hegemonia que o trabalho familiar exerce nessa unidade de produção e consumo" (ibid.: 56). Este nomeado "trabalho acessório" consistiria na transformação periódica do camponês em trabalhador assalariado, compondo a 
"fonte de renda monetária que suplementa o rendimento com as culturas em suas [dos camponeses] propriedades" (ibid.: 57). Em geral, a contratação de trabalho assalariado deverse-ia "ao ciclo de existência da família camponesa, pois há momentos críticos do ciclo agrícola em que os membros da família camponesa não são suficientes" (ibid.: 58). A venda de força de trabalho, normalmente limitada à colheita, teria, porém, que ser analisada em cada caso no que toca à generalização do assalariamento, pois nem sempre quem contrata é um capitalista e quem se assalaria se encontra "totalmente expropriado" (ibid.: 58$)^{80}$.

A diária, da maneira proposta, é suplemento da reprodução camponesa porque repõe o trabalho familiar, ainda que com dinheiro. O cerne do debate é se e em que medida essa forma de trabalho expropria, enquanto divórcio dos meios de produção e restrição das possibilidades de reprodução ao assalariamento. Aqui, a expropriação não é total se repõe a unidade familiar; entretanto, caso ela se efetive, não é incontornável que venha a opor capitalistas a camponeses proletarizados, haja vista a capacidade de remissão da posse da terra em outro lugar:

É assim que o desenvolvimento contraditório do modo capitalista de produção no Brasil age no sentido da expropriação dos camponeses em uma porção do território; entretanto, o camponês expropriado, que pela lógica do capital, deveria proletarizar-se, reconquista a autonomia do trabalho, ocupando novos espaços em terras sem ocupação. É nessa luta pela manutenção da condição de lavrador autônomo, pela conquista da posse que os posseiros, na luta contra o capital, vão construindo o seu próprio regime de propriedade anticapitalista: a posse, a terra de trabalho (ibid.: 71, grifos nossos, D.L.).

O expediente assinalado é sem dúvida o da expansão da fronteira. A questão é como para o autor isso recria a "autonomia do trabalho" e consiste numa "luta contra o capital". No sentido apresentado, tal declaração não se distrai de contextos particulares de coerção na produção de mercadorias, como os que temos tratado? Malgrado a localização do campesinato no desenvolvimento contraditório do modo de produção, a passagem acima não enuncia uma teoria do capital que se reduz à luta de classes? Nessa redução, uma classe, essencialmente, se contrapõe ao capital que lhe explora o trabalho, numa reedição do dualismo examinado por Musumeci (1988). Seria factível aliar a leitura de Oliveira à naturalização e à positivação do trabalho, algo que Kurz (1992) criticaria como imposição histórica de uma forma de mediação

\footnotetext{
${ }^{80}$ O caso em exame é o das vinícolas do Rio Grande do Sul, a partir de pesquisa de José Tavares dos Santos: “Em geral, o período da colheita tem levado o camponês a experimentar o assalariamento. Deve-se verificar caso por caso no seio do território brasileiro, pois, no Sul do país, o assalariado é um proprietário e seu filho; ainda não se trata, portanto, de um trabalhador expropriado totalmente. E o camponês que contrata não é um capitalista, não trava com ele uma relação social de produção especificamente capitalista" (Oliveira, 1991: 58).
} 
fetichista. Dessa feita, para o que nos interessa, fica de fora da apreciação do geógrafo que a relação da monetarização das relações de trabalho com a expropriação pode não se restringir à permanência ou não do lavrador na terra.

Nos estudos de Hébette e Marin (1981) acerca da mobilidade do trabalho na fronteira amazônica, por sua vez, a monetarização das relações sociais é consequência da subordinação do capital mercantil amazônico à condição de agente produtivo do capital industrial, nacional e internacional, comandado do Centro-Sul do país (ibid.: 203). O instrumento da expansão do mercado industrial seria a implantação, pelo território, de uma ampla rede de comunicações integrando Amazônia e Centro-Sul, tendo como efeito indireto a dissolução, via comércio, das “organizações da produção" anteriores (ibid.: 204). Como exprimem, a "abertura do mercado implica na injeção de moeda em regiões e locais onde era apenas ocasionalmente utilizada pelos produtores diretos" (ibid.: 204), assim multiplicando-se os meios de circulação das mercadorias - exemplificadas com a capilarização da rede bancária e com o incremento do consumo de bens industrializados. A monetarização é, também, fomentada diretamente pelo Estado, como na aposentadoria rural e na concessão de crédito, o que, uma vez instituídas, permitem a seus beneficiários ampliarem e diversificarem suas searas de consumo e movimentarem o comércio (ibid.: 205). Os autores, desse modo, veiculam à monetarização o incremento da demanda por mercadorias (ibid.: 205):

A demanda pelos bens ofertados no comércio encoraja um tipo de atividade que proporciona entradas de dinheiro vivo em ciclos reduzidos - atividades de retorno absolutamente oposto ao da agricultura sujeita ao ciclo anual de safras.

Parece que o dinheiro passa a mediar cada vez mais objetiva e preponderantemente relações nas quais era ocasional ou até prescindível, sendo requisitado para a satisfação de necessidades antes não estabelecidas entre os sujeitos. Et pour cause os lavradores são compelidos, segundo Hébette e Marin, a diversificarem suas atividades tencionando embolsarem mais rapidamente pagamentos:

A monetarização da economia leva assim o agricultor a desempenhar atividades complementares à agricultura e de pagamento imediato, ou atividades ocasionais, substitutivas, por tempo limitado (garimpo, por exemplo, estadia propositalmente temporária nas empreitadas de grande rotatividade de força de trabalho [...]) (ibid.: 206).

O que está sendo argumentado é uma diversificação na mobilidade da força de trabalho (Gaudemar, 1977) dos lavradores. No que observamos in loco, juntamente à 
agricultura, o lavrador julga necessário obter dinheiro na medida em que recorre à empreita e à diária, ao garimpo e ao trabalho assalariado na indústria (no caso, a Jari), ao mesmo tempo em que pode permanecer possuidor de terras. Para Hébette e Marin, essa monetarização teria como "efeito infalível [...] a generalização da mercadoria", inclusive, e contrariamente às formas anteriores de produção, tornando mercadorias terra e força de trabalho, pari passu à separação do trabalhador de seus meios de produção $^{81}$ :

Nesse processo de mercadorização generalizada, duas mercadorias merecem destaque porque caracterizam o efeito desintegrador do capital mercantil sobre as formas anteriores de produção: a terra e a força de trabalho. A mercadorização da segunda está, aliás, ligada intimamente à da primeira; pois neste reside um dos mecanismos de separação do produtor do seu meio de trabalho e de suas condições de subsistência (ibid.: 207).

Monetarização, e por conseguinte mercadorização, são tomadas como transformação de "valores essencialmente de uso" em "valores essencialmente de troca" (ibid.: 207), com a desintegração, pelo mercado, das "formas anteriores de produção" orientadas pelo valor de uso $^{82}$ (ibid.: 204). Com tal postulado, vemos que os interlocutores enrevesam os momentos da contradição imanente à mercadoria como válidos e resolvidos por si mesmos, e no qual o valor de uso é naturalizado e independente de relações socialmente determinadas ${ }^{83}$.

Da mesma forma, mercadorização significaria, para os autores, expropriação. A justificativa se aproxima daquela da autonomização, mas é preciso marcar diferenças. A nosso ver, a mercadorização argumentada por Hébette e Marin pode reduzir a expropriação a uma necessária separação física entre o trabalhador e sua base fundiária. Nela, não parece haver margem para perguntar por que motivos a força de trabalho de um lavrador pode ser mobilizada no mercado mesmo que este acesse seus meios de produção, e também apesar da

\footnotetext{
81 “Com o fluxo de dinheiro, tudo se torna mercadoria, objeto de troca imediata e corrente, artigo passível de compra e venda a qualquer momento e sem restrição [...] Objetos até ora geralmente transmitidos por herança e até por cessão gratuita e apenas excepcionalmente vendidos, passam a ser correntemente trocados por dinheiro, como por exemplo: terra, casa, roça, usina, objetos de estimação, hospedagem, até um cafezinho ou bebida, acesso à praia ou ao igarapé" (Hébette e Marin, 1981: 207).

82 "O desenvolvimento do comércio e do capital mercantil leva a produção por toda a parte a orientar-se pelo valor de trocas, aumenta o valor delas, diversifica-a e dá-lhe caráter internacional. O comércio, por isso mesmo, exerce sempre ação dissolvente sobre as organizações da produção que se guiam essencialmente pelo valor de uso" (Hébette e Marin, 1981: 204).

${ }^{83}$ A dialética recai no que Hegel classificaria como o "mau infinito" qualitativo da antinomia kantiana. Em vez da passagem do termo ao seu oposto ser a supressão desse termo na unidade com seu oposto, e sendo estes termos momentos, na dialética transcendental de Kant tal passagem é uma simples ruptura (Hegel, 2012, § 121). Por isso, em lugar de tratar a passagem do valor de uso para o valor de troca com a mercadorização (como o fazem Hébette e Marin), tratamos destes termos enquanto momentos imanentes à mercadoria.
} 
mobilização da terra num mercado. Consideramos que a relação da expropriação com a força de trabalho tem a ver com sua autonomização como mercadoria negociada a dinheiro como desdobramento da territorialização do capital. A modernização é interpretada segundo o estabelecimento de uma aparência de autonomia entre os mercados de capital, terra e trabalho, que ultrapassa a expulsão da terra. Assim, a expropriação pontual é situada no contexto da monetarização, que justificamos como formação da sociabilidade mediada pelo valor, uma relação fantasmagórica entre coisas. O problema, que exige debate, será resgatado no capítulo seguinte.

O desempenho de atividades complementares ou temporariamente substitutivas ao trabalho agrícola, enquanto decorrência de relações mediadas pelo dinheiro na explicação de Hébette e Marin (1981: 206), é colocado por Baumfeld (1984) também como resultante da especificidade da esfera da produção agrícola. Ademais, é pela análise da especificidade da produção agrícola e da fronteira nos países de industrialização recente que o autor busca, como cerne de sua discussão, interpretar a formação do trabalho no Brasil (ibid.: 25). Além da existência da renda fundiária, conforme a qual a elevação do preço da terra mobilizaria intensamente força de trabalho agrícola por curtos intervalos ${ }^{84}$ (ibid.: 33), uma diferença entre o "tempo de trabalho" e o "tempo de produção" seria característica da esfera agrícola (ibid.: 34). Aqui, as "durações significativas dos tempos de não-trabalho" que compõem o "tempo de produção" - por exemplo, o tempo de maturação de uma cultura - criam uma "base objetiva para formas diversificadas de mobilidade da força de trabalho agrícola”. Isto é: na combinação do trabalho no lote familiar com o assalariamento ocasional, com a empreita, com o trabalho em grandes obras e nos garimpos e com o assalariamento urbano (ibid.: 34).

Para Baumfeld, a esfera agrícola se desenvolve da maneira referida por, de certa forma, combinar suas especificidades às da industrialização recente. A modernização das relações técnicas e a monetarização desagregam as "zonas de economia de subsistência", aumentando os custos dispendidos com o trabalho agrícola, que devem ser compensados com uma exploração mais acentuada da força de trabalho (ibid.: 34). Diga-se de passagem, a noção de "zonas de economia de subsistência" só pode ser resultada de uma idealização de

\footnotetext{
${ }^{84}$ Segundo Baumfeld (1984: 33-4), primeiramente, o aumento do preço da terra impede que parte da renda se esterilize nos lotes camponeses, que serviam tanto de complemento de subsistência quanto para fixação de camponeses em grandes empresas agrícolas, remunerados com baixos salários; assim, é mais pertinente o pagamento de salários mais altos durante alguns meses do ano do que isolar parcelas de terra cujos preços estão em elevação. Em segundo lugar, vai inviabilizar os antigos contratos de pequeno arrendamento e parceria, impelindo aqueles camponeses "semidependentes" na relação ao trabalho de diarista ou à ocupação da fronteira. Terceiro: esse aumento induz as empresas a intensificarem o emprego de insumo para maximizarem a produtividade por unidade de superfície, o que também ocasiona substituição de culturas pelas mais rentáveis e especulação com a terra com conseguinte expulsão dos lavradores.
} 
condições de produção que não problematiza a forma de mediação estabelecida pela mercadoria.

Conforme nosso interlocutor, a mobilidade do trabalho agrícola por meio da superexploração consiste na própria forma da modernização recente brasileira, embora tal premissa desconsidere que ser compelido ao trabalho já seja uma exploração inadmissível. No Centro-Sul, explica, "existe um mercado regional e local de FT organizado e adestrado pelo e para o trabalho assalariado", bem como o nível de ocupação econômica e jurídica das terras é praticamente pleno (ibid.: 37). Pensando nos termos de Gaudemar (1977: 190-3), é como se tivesse se constituído a mobilidade da força de trabalho a circular como mercadoria vendida e comprada, segundo as contingências do movimento capitalista, "entre as diferentes esferas de atividade", embora conforme a qualificação dessa força de trabalho "duplamente livre"

Mas onde essas circunstâncias de circulação da força de trabalho não estão postas, como na fronteira, com abundância de terras inexploradas e inexistência de um mercado de trabalho formalmente constituído, o trabalhador precisaria ser fixado segundo artifícios de repressão, ainda que combinados com outras formas de mobilidade ${ }^{86}$, e intermitentemente (Baumfeld, 1984: 41). Explana Baumfeld que assim ocorre no caso do sudeste paraense, em que a peonagem "imobiliza" força de trabalho, em tarefas de derruba de florestas e formação de pastos, pela dívida e vigilância armada, com um complexo sistema de recrutamento interregional $^{87}$ (ibid.: 43).

Manifestamente, ele reconhece que os mecanismos de formação do mercado de trabalho são diferenciados de acordo com a heterogeneidade do conjunto das fronteiras (ibid: 41), reportando-se particularmente a suas pesquisas de campo. As condições da formação do mercado de trabalho na Calha Norte paraense podem, até segunda ordem, ser resumidas na conservação do lavrador como possuidor de terras pari passu à sua dependência, cada vez mais aprofundada, do equivalente geral para se reproduzir. Reiteramos que essa necessidade é

\footnotetext{
85 "A liberdade do trabalho encontra-se totalmente definida nessa dupla determinação: o trabalhador dispõe livremente da sua força de trabalho, mas tem absoluta necessidade de a vender" (Gaudemar, 1977: 190).

86 "Essas características [abundância de terras inexploradas e ausência de mercado de trabalho formalmente constituído] implicam em que nestas áreas [de fronteira], a organização do mercado de trabalho agrícola utilizará formas de fixação e de repressão à força de trabalho, ainda que estas se combinem com outras formas de mobilidade da força de trabalho" (Baumfeld, 1984: 41).

${ }^{87}$ Discutir o funcionamento da peonagem não é exatamente foco deste trabalho. Porém, podemos resumir a querela a respeito da peonagem dissertando que, para Baumfeld (1984: 43-4), tal regime de trabalho não pode ser reduzido à formulação de "forma análoga à escravidão" por caracterizar uma etapa, em particular, da formação do mercado de trabalho e de terras num país de industrialização recente, e que envolve mecanismos complexos de contratação e organização do trabalho, com "imobilização temporária" e circulação dos trabalhadores pelas diferentes fases do processo produtivo. No entanto, dados os próprios argumentos do autor, o que ele chama de "imobilização" não constituiria uma forma de mobilização da força de trabalho?
} 
expressa, no texto, no loteamento e instituição de patrimônios, na venda de terras a dinheiro, nas relações entabuladas em torno dos pimentais, na disseminação do regime de diária e "empeleita" e na diversificação do consumo de bens não produzidos pelos lavradores. Aqui, o trabalho aparece mobilizado segundo uma diversidade de serviços prestados em troca de dinheiro. Esposar o processo de modernização das relações de produção como autonomização do capital em suas diferentes categorias permite que os procedimentos de expropriação sejam vistos para além da separação física do produtor de seus meios de produção. E mesmo que o processo tenha aparência de continuidade para seus agentes. Daí podermos, por intermédio da interpretação do processo aludido, problematizar: de que lavrador e que relação com a terra e com o trabalho na fronteira, afinal, estamos tratando? As relações são as mesmas de antes?

\subsection{Autonomização do Estado, colonização e dissolução das dinâmicas regionais?}

Abrimos nossa dissertação discorrendo sobre políticas estatais nas áreas de fronteira da margem esquerda do Baixo Amazonas, entre meados do século XIX e primeiro terço do século XX, situando-as como ensaios de constituição do território estatal. Ali, políticas de colonização e de formação de uma população trabalhadora nacional compunham o rol dos esforços de modernização por parte de um Estado periférico também em constituição. Tal temática, à primeira vista, ficara um tanto afastada da discussão dos dois últimos capítulos, embora seja distinguível, nestes, elementos daquela autonomização do Estado, em seu momento regional, na formação de relações de trabalho para valorizar capital no país. A intenção, agora, é mostrar como a institucionalização do Estado é momento necessário da formação de terra, trabalho e capital como mercadorias aparentemente autônomas, transacionáveis em mercados juridicamente regularizados e fontes de rendimentos, também prima facie, independentes entre si. A determinação dessa aparência de autonomia implica mudanças de práticas e na consciência dos sujeitos que personificam e reproduzem continuamente o processo de autonomização; daí esta não tratar do encobrimento de uma verdade terna e imutável. Assim considerando, fatores antes apontados apenas de passagem são retomados e mais demoradamente interpretados, tal como são problematizadas mudanças quanto à forma de atuação estatal e de sua autonomização como esfera política também reguladora do mercado e dependente de dinheiro.

Políticas territoriais que evidenciam a intervenção estatal na área pesquisada podem ser enumeradas, notadamente, na construção de estradas de rodagem, na demarcação fundiária e na concessão de crédito rural - mesmo que, reconhecidamente, o último elemento tenha sido 
ainda pouco examinado. Estas políticas encetam modificações nas relações de trabalho e com a terra entre os lavradores na fronteira, mas, ao que nos parece, não devem ser minimizadas a uma chegada repentina do Estado, como agente externo às relações de produção na área.

A ocupação de "terras livres" pelos lavradores pode caracterizar uma "colonização espontânea", nos termos das pesquisas em torno da fronteira, que, porém, é mediada por mecanismos da gestão estatal. Nesses termos, ao estudar a migração rural para a Amazônia Octávio Ianni (1979) conclui que:

na prática, as migrações de trabalhadores rurais para a Amazônia, ou o processo de colonização espontânea, configurava uma reforma agrária realizada por esses mesmos trabalhadores e os seus familiares (ibid.: 14).

Que elementos presidem a mobilização dos trabalhadores rurais é algo negligenciado, de resto não sendo exagero evocar, por assim dizer, uma aproximação com uma essência camponesa anticapitalista. Mais adiante, Ianni reduz as determinações sociais da produção familiar na terra à reforma agrária espontânea, contrária ao Estado e a suas políticas de regularização fundiária. Essas medidas estatais serviriam para "proteger a grande propriedade" (ibid.: 27) e "para controlar, subordinar ou suprimir os núcleos de posseiros que se formavam e continuam a formar-se em terras devolutas, tribais e de latifúndios" (ibid.: 29). Então, a "colonização espontânea" difere de políticas de "colonização dirigida" pelo Estado na Amazônia sobretudo a partir de $1970^{88}$, seja com a programação de todo o processo de povoamento ("colonização oficial") seja fomentando a atuação de empresas de colonização ("colonização particular") (ibid.: 57). São ações que denunciam "como o poder estatal procurou bloquear, orientar, integrar, disciplinar ou subordinar a reforma agrária espontânea à colonização dirigida" (ibid.: 57). Para tanto, havia a intenção de transformar os núcleos coloniais em locus da "produção de gêneros e força de trabalho para servir de base à criação e expansão da grande empresa agrícola" (ibid.: 64).

Assim considerando, temos no sociólogo uma crítica clara em relação à forma com que a ditadura organiza a ocupação do território, no deslocamento forçado do trabalhador rural e no favorecimento da agroindústria à revelia da reforma agrária. Seguindo essa mesma linha argumentativa, porém, duas noções de colonização essencialmente opostas separam

\footnotetext{
${ }^{88}$ Em 1970, o regime militar institui o Programa de Integração Nacional (PIN), o que, segundo lanni (1979, cap. IV), centraliza e excuta nacionalmente a construção de rodovias e a ocupação fundiária das margens deles, reorientando a migração de populações do Nordeste para a Amazônia e criando as condições de incorporação da fronteira à economia de mercado, a exemplo do que ocorrera na Transamazônica. Retornaremos à questão dos planos nacionais efetivado pelos militares mais adiante.
} 
atributos, digamos, camponeses e capitalistas da terra. Uma dicotomia da qual se distancia a perspectiva o volume Colonização para quem?, de Jean Hébette e Rosa Marin (1979). Isso porque, no texto, a dupla de autores expressa:

Colonização espontânea e dirigida não são, na verdade, dois processos perfeitamente distintos ou duas formas nitidamente separadas de colonização, uma acompanhada por interferência externa (do Estado ou de uma entidade privada), outra isenta dela (ibid.: 114).

Eles ainda comentam um problema recorrente na leitura da colonização espontânea, que a qualifica como desorganizada, como se tal colonização já não fosse estimulada por "processos econômicos de compulsão e necessidades" (ibid.: 113). E também porque "a colonização dita espontânea não é menos condicionada pelas políticas governamentais que a dirigida, embora o seja de forma diversa" (ibid.: 114). A diferença, para os interlocutores, é muito mais tributária dos momentos e da intensidade da interferência do poder público, posto que, na colonização dirigida, há interferência direta e orientação formal do Estado na fase inicial do processo. A colonização espontânea, por seu turno, não experimenta "imposição sistemática ou orientação positiva", ficando o processo "a critério dos indivíduos ou grupos colonizadores" (ibid::114). Na apreciação que fazem da obra de Darcy da Silva, nossos autores observam que esta forma de colonização é condicionada por certas políticas, impositivas ou permissivas, que repercutem nos lugares de residência anterior dos colonos ou na própria área de colonização. Dessa forma, fatores de intervenção direta, como a política fundiária e creditícia, ou indireta, como a edificação da malha de transportes e comunicações, ensejam os deslocamentos nos termos mencionados (ibid.: 115). A distinção perante a colonização planejada consistiria em que, nesta, o Estado escolhe a área e que grupos a ocupará, resultada de políticas de “integração nacional” (ibid.: 115).

Os processos sumariados são, sem dúvida, patentes na área que pesquisamos. Se a povoação das paragens do Limão e arredores, de algum modo, configura uma colonização espontânea, ela não deve se desviar da mediação por "processos econômicos de compulsão e necessidades", nas palavras de Hébette e Marin (ibid.: 113). Aliás, toda a exposição delineada no capítulo acerca da formação de tal comunidade é permeada pela análise do monopólio da circulação para a produção de mercadorias como finalidade irracional do processo formativo; ou seja, é uma lógica agenciada pelos sujeitos, mas que passa às costas destes. O posseamento da "terra liberta", no caso, está a cargo dos grupos de lavradores e do comerciante que personifica a violência do comando sobre o trabalho. Esta se torna viável, por sua vez, devido 
a fatores como o transporte fluvial e, possivelmente, por alguma propaganda sobre o local, promovida por Wilson.

Resgatando nosso capítulo de abertura, as políticas de colonização movidas pelo Estado em constituição podem ser enumeradas partindo da fundação da Colônia Militar de Óbidos, em 1854. Em 1894, são criadas a Colônia de Monte Alegre e, em Alenquer, a Paes de Carvalho. Em 1927, a noroeste da sede de Monte Alegre, é fundada a gleba Inglês de Sousa, em 1942 incorporada à Colônia Agrícola Nacional do Pará (Canp). Na década de 1930, na direção, porém adiante, da Serra do Itauajuri o Estado institui a gleba Major Barata (Menejó) e a gleba Mulata. O que muda na configuração territorial, nessa altura da exposição, é que seguindo pelo caminho além da Mulata, na direção norte, observamos o avançamento de procedimentos de demarcação simultâneos à construção da PA-254, na fundação do Projeto Integrado de Colonização Monte Alegre ${ }^{89}$.

Este planejamento mais recente da colonização pode ser evidenciado, em especial, no exame do Programa operacional do Incra, voltado para o Projeto Integrado de Colonização de Monte Alegre (PIC MA), datado de 1975 (Incra, 1975). O plano de atividades operacionais se resume a regularizar a distribuição da terra e canalizar recursos financeiros para a gestão do projeto. O relatório está dividido em doze capítulos (“programas”), cada um deles expedindo um diagnóstico, relatando o nível operacional das atividades e a programação operacional, concluindo com um plano prospectivo.

O capítulo de abertura trata do programa de distribuição fundiária, relatando que as áreas que integram o PIC MA são fruto de doações do governo do Pará à União. O PIC, pois, reuniria três áreas que já estavam sob tutela federal, nomeadamente as glebas de Inglês de Souza, Mulata e Major Barata, cujas datas de fundação se referem a decretos de 1927, 1942 e 1943, respectivamente. O intuito seria "dar prosseguimento ao processo de colonização iniciada pela Colônia Agrícola Nacional do Pará", tendo seu estabelecimento em 1971, quando suas parcelas componentes são averbadas em nome do Incra, somando 467396 ha (ibid:: s/p). No diagnóstico consta que, na gleba Inglês de Souza, aproximadamente cinquenta proprietários rurais apresentaram seus títulos de domínio, crendo os relatores que outros viriam a fazer o mesmo nas glebas Mulata e Menejó. Até 1975, nenhum título definitivo havia

\footnotetext{
${ }^{89}$ No livreto Amazônia: monopólio expropriação e conflitos, Ariovaldo Umbelino de Oliveira (1990: 93) descreve um Projeto Integrado de Colonização como modalidade de colonização na qual o Incra é incumbido de toda organização territorial e administrativa, assentando e titulando os beneficiários e promovendo assistência técnica, ensino, saúde, previdência e habitação, bem como auxiliando no armazenamento e comercialização da produção. No Pará, foram executados seis projetos com essas características, datado o PIC Monte Alegre de 1971, com pretensão de assentar 2600 famílias (ibid.: 96).
} 
sido expedido aos beneficiários do Projeto, embora alguns já tivessem pagado por suas parcelas. Daí programar o Incra, entre outras medidas, implantar a titulação definitiva da terra, avaliando 2084 parcelas rurais e 350 lotes urbanos (sede das glebas).

O segundo programa trata das tarefas de demarcação no projeto. O diagnóstico é que o loteamento não foi planejado, por falta de um estudo técnico de aproveitamento da área. Apesar disso, "desde a época da Colônia Agrícola Nacional do Pará vem-se fazendo uma colonização organizada, no assentamento de famílias em áreas de 25; 30 e 100 ha, ao longo das estradas e rios" (ibid.: s/p). As tarefas de demarcação não haviam sido concluídas, e por isso o instituto programava lotear as parcelas das glebas ${ }^{90}$, primeiro delimitando os perímetros do PIC e das glebas. Também, previa-se a construção de estradas, loteamento dos terrenos, locação dos prédios da administração e elaboração de plantas e memoriais descritivos de cada uma das parcelas.

Assim, o quarto programa previa o assentamento das 2634 famílias que ocupam os lotes do projeto, ainda que pudessem existir grupos não identificados pelo Incra. A intenção era realizar todas as fases do assentamento, da seleção e identificação ao encaminhamento das famílias para as parcelas a elas designadas, tendo em vista a emancipação do PIC (ibid.: s/p).

No quinto programa encontramos uma descrição das unidades agrícolas. Para a gleba Mulata, é relatado o primado das culturas de subsistência e da criação extensiva, sobretudo com o cultivo de milho, arroz, farinha, pimenta-do-reino e feijão, e a criação de aves caipiras, seguida de bovinos (Quadro 1). A produção é vista como empregando pouca tecnologia, com exceção do ocorrido nos lotes dos japoneses, que "utilizam, inclusive, alguns insumos modernos" no cultivo de pimenta-do-reino, encaminhada para Manaus (ibid.: s/p). Na época, cerca de $80 \%$ da gleba era praticamente desabitada e desconhecida, principalmente nas passagens para além da rodovia PA-28 (atual PA-254). Apesar disso, os técnicos do Incra enxergavam ali a vocação para a exploração madeireira e mineral - jacarandá, maçaranduba, cedro, copaíba, pereira, miracatiara e andiroba, além de pelo menos duas jazidas de calcário (ibid.: s/p). Na gleba Inglês de Souza também predominaria uma agricultura de subsistência, com emprego de métodos rudimentares de produção, notavelmente de banana, milho, feijão,

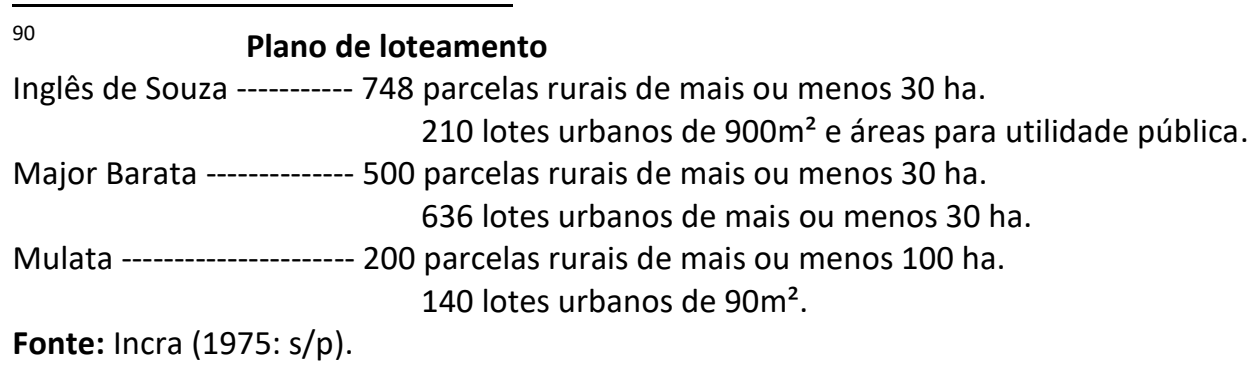


juta e fumo. Entretanto, o instituto vislumbrava o desenvolvimento do cultivo, em virtude de solos que permitiam mecanização, e a despeito da falta de assistência técnica, de mecanização e de crédito e infraestrutura para comercialização (ibid.: s/p).

\section{Quadro 1 - Produção agropecuária do PIC Monte Alegre}

\begin{tabular}{|c|c|c|c|c|c|}
\hline \multicolumn{3}{|c|}{ Produção agrícola da Gleba Mulata (1972) } & \multicolumn{3}{|c|}{ Produção pecuária da Gleba Mulata (abr/1973) } \\
\hline Cultura & Produção (kg) & Rendim. méd. & Rebanhos & No Cabeças & Observaçōes \\
\hline Milho & 822970 & $1450 \mathrm{~kg} / \mathrm{ha}$ & Bovinos & 4036 & Nelore, gir, guzerá \\
\hline Arroz & 426560 & $1500 \mathrm{~kg} / \mathrm{ha}$ & Suinos & 922 & Criação extensiva \\
\hline Farinha & 316528 & $\ldots$ & Equinos & 378 & Tipo comum (regional) \\
\hline Feijão & 92220 & $1440 \mathrm{~kg} / \mathrm{ha}$ & Caprinos & 124 & Id. \\
\hline Pimenta & 114180 & $3 \mathrm{~kg} / \mathrm{pé}$ & Aves & 10804 & Maioria caipira, extensiva \\
\hline Juta & 35038 & - & Total & & 12264 \\
\hline Fumo & 51890 & - & & & \\
\hline Tomate: & 45000 & $1,2 \mathrm{~kg} / \mathrm{pé}$ & & & \\
\hline Repolho & 3000 & $1,2 \mathrm{~kg} / \mathrm{pé}$ & & & \\
\hline Hortaliças & 2500 & - & & & \\
\hline
\end{tabular}

Fonte: Incra (1975: s/p). Adaptado por D.L.

O programa parece fortalecer uma noção depreendida das narrativas dos lavradores que vivenciaram o processo de loteamento naquela época. O Estado já dispendia, há um tempo, esforços no intuito de colonizar a área, mas muito lentamente executava o exercício preterido de titular a terra. Em 1975, nem mesmo a demarcação havia sido concluída, e já demandaria uma série de outras atividades associadas - elaboração de plantas e construção de estradas e edifícios de administração. Ao menos, consideramos que a análise da programação da colonização no que respeita a terra significa, aqui, juridificar alocando lavradores, com a pretensão de alargar a produção na área. Daí, por um lado, uma avaliação negativa das unidades agrícolas e seus métodos de cultivo, bem como da ausência de assistência técnica, crédito e infraestrutura para comercialização da produção. Há, por outro, o acento empregado na mecanização e na "vocação" para a produção madeireira e mineral. O que não aparece são os efeitos do loteamento - e do lapso temporal com a titulação - enquanto intensificação do processo de compra e venda de terras, tal qual discutido no início deste capítulo.

Os programas subsequentes dissertam acerca da infraestrutura existente e prevista para o PIC, passando pela educação, saúde e previdência social e habitação, junto dos quais pensamos poder adicionar o terceiro capítulo, sobre a administração do projeto. As condições infraestruturais são mostradas no relatório por meio de uma apreciação do sistema viário 
local, composto de trinta linhas e vicinais, totalizando $372 \mathrm{~km}$. Dos $227 \mathrm{~km}$ de estradas que seriam beneficiadas, receberam melhoramentos apenas 34, na gleba Inglês de Souza. A justificativa era de deficiência de equipamento pesado, embora o Incra ainda planejasse a abertura de mais $190 \mathrm{~km}$ de estradas e restauro de outros $90 \mathrm{~km}$. Também, esperavam perfurar poços nos lotes e erguer caixas d'água nas glebas, e consideravam concluídas as tarefas em torno da administração das escolas, postos de saúde e habitações.

O diagnóstico da administração é efetuado a partir de uma listagem das instalações presentes nas glebas do projeto, contando-se, entre outros edifícios, escolas, postos médicos, açougue, oficina, depósitos, serraria, caixa d'água, estação de rádio e casa de força e luz. Todas as máquinas e implementos agrícolas localizavam-se em Inglês de Souza, sede do PIC.

O Incra esperava realizar a manutenção dos imóveis e maquinários do projeto, bem como adquirir novos equipamentos e regularizar a situação de alguns de seus funcionários. Quanto ao pessoal administrativo, o PIC mantinha 155 funcionários, sendo 36 deles do quadro permanente, 49 no regime de CLT e outros 70 contratados, remunerados com as verbas repassadas para o Projeto. Para a realização das obras de infraestrutura e manutenção das glebas, o órgão dispunha da colaboração de outras instituições, de acordo com as funções a estas atribuídas, como o DER, o Movimento de Educação de Base (MEB), o Funrural e o Banco da Amazônia (Basa). O plano era transferir a administração do projeto da gleba Inglês de Souza para a cidade.

É destacável que este corpo de funcionários recebe um ordenado, integral ou durante a vigência de um contrato. Aqui, o Estado deve territorializar relações capitalistas de produção formando força de trabalho e mobilizando-a em tarefas administrativas e de construção de infraestruturas. Nesse sentido, ele próprio confere à força de trabalho uma condição de mercadoria vendida no mercado, remunerada via salário, e cuja exploração baliza o processo de valorização empreendido pelo planejamento. Por sinal, como já colocamos, boa parte dos moradores da Canp (a antiga Inglês de Souza) mantivera relações bastante próximas ao Incra, tendo alguma vez na vida lá trabalhado, ou, atualmente, encontrando-se aposentado pelo instituto. A partir da análise da folha de pagamentos dos funcionários (Quadro 2), notamos a variação de serviços movidos, do corpo docente a empregados administrativos, técnicos de oficina, carpinteiros, etc. Os cargos melhor remunerados - do regimento administrativo - são compostos de indivíduos cuja força de trabalho é produzida segundos mecanismos mais complexos, que exigem maior tempo de formação, e que, algo frequentemente, é trazida de Belém. 


\section{Quadro 2 - Contra recibo dos funcionários do PIC Monte Alegre (em Cr\$)}

$\begin{array}{ccccccc}\text { Função } & \text { Quant. Sal. unit. Mens. Sal. total mensal } & \begin{array}{c}\text { Sal. total } \\ \text { anual }\end{array} & \begin{array}{c}\text { Encargos } \\ \text { sociais }\end{array} & \begin{array}{c}\text { Total } \\ \text { geral }\end{array} \\ \text { Motorista } & 5 & 800 & 4000 & 52000 & 13000 & 65000 \\ \text { Trab. Rural } & 1 & 600 & 600 & 7800 & 1950 & 9750 \\ \text { Mestre de obras } & 1 & 800 & 800 & 10400 & 12600 & 23000 \\ \text { Ajud. Ensino } & 10 & 600 & 6000 & 78000 & 1950 & 79950 \\ \text { Mecânico } & 3 & 850 & 2550 & 33150 & 8290 & 41440 \\ \text { Prat. Enfermagem } & 1 & 800 & 800 & 10400 & 2600 & 13000 \\ \text { Reg. de Classe } & 3 & 1080 & 3240 & 42120 & 10530 & 52650 \\ \text { Tratorista } & 2 & 750 & 1500 & 19500 & 4880 & 24380 \\ \text { Org. Econ. Doméstica } & 1 & 1000 & 1000 & 13000 & 3250 & 16250 \\ \text { Aux. Escritório } & 1 & 900 & 900 & 11700 & 2930 & 14630 \\ \text { Pedreiro } & 1 & 800 & 800 & 10400 & 2600 & 13000 \\ \text { Total } & & 8980 & 22190 & 288470 & 64580 & 384220\end{array}$

Fonte: Incra (1975: s/p).

Se o Estado se institui agente da modernização, em um determinado sentido ele deve forçar a circulação de força de trabalho, expropriando produtores de suas terras e conduzindoos pelo território. Isso cabe numa certa medida, porém. Se o intuito de fundação do PIC é a colonização, uma parte dos empregados, notadamente os que se dedicam à infraestrutura - e que, amiúde, são contratados -, também possuem seus lotes de terra e neles produzem. Entre os funcionários melhor remunerados, por sua vez, a terra não aparece como meio de produção: primeiro porque a reprodução fica integralmente mediada pelo dinheiro adquirido pelo assalariamento; e segundo porque, oficialmente, o Incra vedava a seus funcionários serem beneficiários de projetos de colonização ${ }^{91}$.

O relatório ainda pondera sobre a cooperativa, a disponibilização de crédito e o fomento à comercialização. É pautado que a Sociedade Cooperativa Mista de Monte Alegre (Socama) é dividida em quatro seções administrativas: compra, transporte, beneficiamento e venda, contando 25 sócios brasileiros e 19 japoneses. Quatro destes últimos eram engenheiros agrônomos que prestavam assistência técnica informal e visitavam quadrimestralmente as lavouras (ibid:: s/p). Naquele ano, o capital integralizado da cooperativa era de Cr\$ 66770 , 00; e o subscrito, Cr\$ 67 390, 00. Na safra do ano agrícola 1973/74, a produção de pimentado-reino fora, de longe, a preponderante, gerando Cr\$ 575 194, 34 de divisas, em 71837 kg,

\footnotetext{
${ }^{91}$ Isso vai aos poucos mudando. Alguns funcionários aposentados pelo Incra não raro acumulam terra através da compra dos lotes originalmente destinados aos colonos.
} 
seguida da de arroz, com 400 sacos de $60 \mathrm{~kg}$, somando Cr\$39 392, 00. Apesar de tudo, das 2070 famílias parceleiras no PIC, apenas 44 eram cooperadas, tentando os sócios angariar mais membros para a associação. Havia pequeno crédito de custeio fornecido pelo Banco do Brasil (BB) e empréstimo para capital de giro disponibilizado pelo Banco da Amazônia (Basa), movimentando, na cooperativa, $\mathrm{Cr} \$ 133$ 363, 44. Congregado a isso, os cooperados ainda solicitaram ao Incra o financiamento de maquinário e implementos agrícolas, tal como receberam, do BB, um empréstimo para a aquisição de fertilizantes.

Entre os moradores do PIC, a situação era um tanto adversa em relação àquela da cooperativa. Os relatores do Programa elencavam que, até outubro de 1974, apenas dois parceleiros haviam sido financiados pelo Basa - sendo que estes também eram sócios da Socama -, e dezesseis pelo Banco do Brasil, somando Cr\$ 115 220, 00. Monte Alegre, na época, contava somente uma agência bancária (do Basa), operando estritamente com crédito de custeio, enquanto em Santarém a unidade do BB dispunha financiamentos para pecuária, se bem que unicamente para casos em que os beneficiários ofertassem garantias. Portanto, o parecer é de que "o fator principal da ausência de crédito é a falta de titulação das parcelas", que deviam assegurar ao banco o pagamento dos empréstimos. É comentado que a escassez de crédito disponível, igualmente, se devia à situação da antiga cooperativa do município, em que 124 associados se encontravam em inadimplência, o que levaria o Basa a retrair seus empréstimos. Diante disso, o programa previa ampliar o acesso ao crédito de custeio e para obtenção de fertilizantes. Tal como planejava, para a cooperativa, a compra de um navio e a edificação dum depósito em Belém, visto que o diagnóstico em relação à comercialização da produção agrícola era desfavorável (ibid.: s/p).

Devido ao pequeno número de sócios, a Socama comercializava apenas parte da produção, ficando o restante desta a cargo de intermediários, que ofereciam aos lavradores preços inferiores aos da cooperativa, na base do escambo ou com pagamento à vista (ibid.: s/p). Da parte das vendas efetuadas pela Socama, os gêneros eram escoados para Belém, Manaus e Santarém, onde os pagamentos eram embolsados à vista, e para São Paulo, que comprava sempre a prazo; a exceção havia sido a exportação, duas vezes, para os EUA. As condições para o desenvolvimento da produção não eram oportunas, já que as informações comerciais chegavam aos cooperados por correspondência e, muitas vezes, posteriormente às transações. Assim, a avaliação é de que a estocagem era deficiente, a somar com uma série de dificuldades encontradas pelos parceleiros, como ausência de crédito bancário e de informações sobre mercados, além da precariedade na assistência técnica (ibid.: s/p). 
Consideramos que a questão acerca da presença mais nítida do dinheiro, no contexto, é intrínseca à atuação do Estado, na disponibilização de capital na forma de crédito bancário, não obstante o parecer sobre a insuficiência de tais financiamentos. Os redatores do programa personificam perspectivas modernizadoras, vistas no aumento da circulação monetária que, por consequência, incrementaria a produtividade do trabalho na terra, também dinamizando a comercialização de gêneros agropecuários. Ao que parece, os empréstimos poderiam ser vertidos na aquisição de maquinário e insumos agrícolas e na formação de capital de giro a movimentar a cooperativa. Ao passo que o que impossibilita a disseminação de empréstimos é a falta da titulação, fica justificada a implementação do PIC, algo que sustentamos ser um momento da formação do Estado nacional como agente que, ao liberar dinheiro, autonomiza e regula um mercado de terras segundo padrões produtivos que façam competitiva a área num mercado agropecuário nacional. $\mathrm{O}$ projeto de modernização tem pretensão de ser exercido à revelia das formas da produção e circulação, por exemplo, baseadas no escambo, como aquelas comandadas por intermediários. Talvez a troca direta de produtos seja avaliada, pelos técnicos, como insígnia de "atraso" diante dos padrões de produção exigidos pela acumulação centralizada no Estado, o que não enseja a extinção necessária dessas formas de transação.

Temos que, no limite, o Programa que apresentamos separa na atuação do Estado o comando da constituição contraditória e em processo de mercados de terra, trabalho e capital. Situamos essa formação como parte dos esforços de modernização recuperadora, que Kurz (1992, cap. 8) define como projeto de acumulação dos Estados terceiro-mundistas. No caso, o Estado brasileiro in fieri procuraria repetir as mesmas estruturas de acumulação dos "países avançados", só que num ínterim muito mais reduzido e sem jamais alcançar os níveis de produtividade almejados. Essa modernização tem seu engate na promoção de processos análogos à acumulação primitiva sem, contudo, incorporar as massas desarraigadas à máquina de exploração empresarial, colocando-se, justamente por não ter engendrado as formas esperadas de ocupação da estrutura social, em termos negativos ${ }^{92}$ (ibid.: 188-92). O que sugerimos é que, embora essas intervenções aspirem à realização as expensas dos padrões

\footnotetext{
92 Para Kurz (1992: 193), somente com os planos executados via Estado na década de 1970 supera o Brasil sua condição pré-capitalista. Ao assim ponderar, o autor deixa de observar em nosso passado colonial uma forma originada com um sentido dado na produção de mercadorias tropicais (cf. Prado Jr. 2000), parte da totalidade em processo da modernização. Ressaltemos que, quando circunscrevemos a modernização brasileira à tentativa de recuperação de modelos de produtividade dos países centrais, dela vem acompanhada uma forma particular de territorialização de relações capitalistas de produção, do período colonial ao momento regional e à contemporaneidade. A apresentação desse conceito nos faz distanciar daquele de "capitalismo autoritário" de O. Velho (1979), na medida em que este pressupõe tipologias de modernização nas quais o "capitalismo burguês" é o modelo ideal a ser seguido e, quiçá, alcançado mediante uma plataforma política de Estado.
} 
regionalmente postos de acumulação, muitas das dinâmicas regionais (Oliveira, 2008) que temos levantado parecem, até hoje, reproduzidas. Em nossa pesquisa, o foco é perceber como essas dinâmicas se transformam e, ao mesmo tempo, podem ou não manter a aparência de continuidade nas relações de trabalho e com a terra na fronteira.

Em algumas passagens da introdução de sua Elegia, Chico de Oliveira (2008) levanta uma questão acerca da reposição contínua das condições regionais de reprodução do capital. O autor enquadra a formação nacional num contexto global de reprodução ampliada do capital que, em nossa leitura, desnaturaliza a relação entre Estado e região como entes autônomos em relação à totalidade. Assim, em lugar da abordagem de "desequilíbrios regionais", que confere à região, dada, uma aparência de atraso a ser superado pela intervenção estatal, o enfoque se desvia para as diferenças na divisão regional do trabalho, que configuram especificidades da reprodução do capital no espaço. A ponderação permite a Oliveira situar o planejamento entre as contradições da reprodução capitalista em escala regional e nacional, de maneira que o Estado, longe de mediar conflitos decorrentes das diferenças inter-regionais, encontra-se "capturado" pelas "formas adiantadas da reprodução do capital" (ibid.: 149). O sentido é de forçar a homogeneização das formas de reprodução, diante de espaços onde se reproduzia uma forma específica do capital, passando para o Estado a relação entre economia e política antes fusionada na região (ibid.: 149). Daí,

uma região tende a desaparecer [...] na mesma medida em que as várias formas do capital se fusionam, primeiro pela predominância do capital industrial, depois pela fusão entre capital bancário e industrial, dando lugar ao capital financeiro, e posteriormente, na etapa monopolista do capital, pela fusão entre Estado-capital (ibid.: 149-150).

Em nossas palavras, as particularidades regionais - em suas relações com terra e trabalho voltadas à acumulação - tendem a desaparecer porque tendem a ser homogeneizadas pela reprodução ampliada do capital. A fusão entre economia e política, visível na violência executada pela classe dominante regional, se autonomiza no Estado, que fusiona em si as formas diversas do capital, ao mobilizar força de trabalho na produção de mercadorias. Nos termos da apreciação marxiana da assim chamada acumulação primitiva, a "violência extraeconômica" na coação ao trabalho é monopolizada pelo Estado e só excepcionalmente empregada. De resto, o trabalhador internaliza essa necessidade, ao passo que confiado à perpetuação de "sua dependência do capital que se origina das próprias condições de produção" (Marx, 1. I t. II, 1986: 277). É de se pôr em dúvida a homogeneização, na medida 
em que é permissível a nós indagar se o capital executa a função de forçar integralmente a exploração do trabalho. Ou melhor, é de se indagar sob que aspectos ocorre ou não dita homogeneização destruindo e centralizando o excedente regional. Ao menos, a intervenção do Estado acontece na direção de compelir a essa forma de coerção ao capital.

É como se na Calha Norte paraense, esquematicamente, a dominação, antes visível no monopólio da circulação que capitaneava a mobilização regional do trabalho (cf. cap. 2), se dirigisse para os esforços de dominação do Estado presidindo a mobilização do trabalho para a valorização do valor (Gaudemar, 1977), instigando à circulação da mercadoria força de trabalho pelo território nacional. Quando recorremos à Oliveira (2008: 140), observamos que tal modernização, do prisma do planejamento, consiste nada mais do que na "racionalização da reprodução ampliada do capital", reduzindo a região a coeficientes de "desequilíbrio", solucionáveis pela alocação ótima de fatores de produção no espaço (ibid.: 140-2). Temos, pois, que o processo de formação da região pela divisão internacional do trabalho, tal como os conflitos daqui decorrentes, são negligenciados pelo planejamento, em vistas da programação da territorialização de relações capitalistas de produção. Aliás, tal crítica é extensível também ao Programa do Incra por nós examinado.

Sugerimos que essas políticas territoriais são impostas conforme o Estado vai, contraditoriamente, institucionalizando-se agente que elabora a modernização recuperadora. Trata-se dum processo que vai se delineando com a crise do escravismo e os primeiros planos de colonização de meados do século XIX, e se intensificando com intervenções estatais desenvolvimentistas transcorrentes desde o regime Vargas, na década de 1930, para culminar na ditadura civil-militar ${ }^{93}$. Parece-nos que, apenas neste período, decretos de Estado vão

\footnotetext{
${ }^{93}$ Uma análise das políticas desenvolvimentistas nesse período e sua localização na conjuntura do mercado mundial excede o escopo dessa dissertação. Contudo, acerca do tema cf. especialmente como, em sua Crítica à razão dualista, Chico de Oliveira (2013) relaciona a economia nacional na ditadura a políticas seletivas de combate à inflação, com aumento dos créditos e gastos governamentais e estímulo à demanda, sustentadas no arrocho salarial. O capital financeiro, ao estruturar o mercado, enseja uma superacumulação que, no plano das políticas, se realiza com subsídios às empresas e proteção tarifária, retornando na ampliação da monopolização do capital. O resultado é um resgate reiterado de empréstimos que vão endividar o país e se desdobrar, na política interna, no intento de recrudescer a exploração do trabalho. Complementemos essa análise objetando que a exploração só poderia ser, no patamar do capital requisitado para ampliar a acumulação, mera tentativa mesmo; mas este é assunto para o próximo capítulo. Tanto da obra de lanni (1979) quanto de A. Oliveira (1988 e 1990) extraímos que na Amazônia o processo acima aludido se deu através das políticas comandadas pela Superintendência para Valorização Econômica da Amazônia (Sudam), resultada da Operação Amazônia, datadas, ambas, de 1966, no esforço de montagem, ali, de uma indústria de bens duráveis. A centralização dos capitais amazônicos no Estado monopolista brasileiro, por subsídios e incentivos fiscais, vai favorecer a instalação de conglomerados industriais do Centro-Sul do país e internacionais na forma de grandes latifúndios agroindustriais e pecuários. Sobre os efeitos das políticas de modernização no Nordeste, o balanço da Sudene por parte de Oliveira (2008) dispensa outra apresentação.
} 
operando um corte com as formas regionais de acumulação, se bem que sui generis. Essa singularidade é desígnio de análise.

Relembrando a obra de Ianni (1979) aqui investigada, o sociólogo resume a função do Incra a artifícios de planejamento da contrarreforma agrária em escala nacional. O autor levanta que o Incra surge, em 1970, com o intuito de deslocar contingentes para implantação de planos governamentais de fomento a grandes projetos minerais e agropecuários (ibid.: 41). Para tanto, o instituto atuaria a partir de programas de colonização, pensando na distribuição de terras na Amazônia para lavradores do Nordeste, onde inexistia qualquer interesse na realização de reforma agrária ${ }^{94}$ (ibid.: 62). A estruturação da Transamazônica - mas também de outras estradas - pelo Programa de Integração Nacional (PIN), a partir de 1970, pretende incorporar a estratégia de ocupação territorial amazônica ao desenvolvimento do Nordeste, planejando o transporte de contingentes da segunda para a primeira área (ibid.: 62). Daí o Programa, junto ao Incra, executar a ocupação das faixas limítrofes das rodovias, distribuindo lotes de 100 ha a serem quitados pelos parceleiros num prazo de até vinte anos, e passando do estado à federação a jurisdição dessas terras devolutas (ibid.: 60).

Por seu turno, M. de Oliveira (2002) assinala que o período pós-1964 coincidiu com a disseminação de políticas de desenvolvimento da Amazônia. Estas são descritas como projetos governamentais que resultaram na construção das principais rodovias regionais e de seus planos de colonização, bem como na implantação de "grandes projetos para uso dos recursos naturais" (ibid.: 47-8). Segundo a autora, as iniciativas "repercutiram de forma discreta" na margem esquerda do Baixo Amazonas, tendo como consequências mais notáveis, de um lado, a implantação do Projeto Porto Trombetas em Oriximiná, em 1974, destinada à exploração de bauxita pela Mineração Rio do $\operatorname{Norte}^{95}$ (MRN). De outro, a construção da PA-

\footnotetext{
94 O lema de Médici é sintomático: “terras sem homens [na Amazônia] para homens sem terra” do Nordeste.

95 Recordemos que a obra Negros do Trombetas (Marin e Castro, 1997), apresentada no primeiro capítulo, trata dos conflitos das "comunidades remanescentes de quilombos" com projetos minerais e hidrelétricos no alto curso do rio Trombetas. As autoras mostram que a MRN é criada em 1967 obtendo 65552 ha de concessão de terras, adquirindo ainda uma propriedade de 400 ha e solicitando uma doação de 87258 ha junto ao Incra. Antes que tivesse seu pedido aprovado, a empresa cerca a área e fecha "acordos" com os locais para que estes desocupem seus terrenos. Para completar, corroboram na criação da Reserva Biológica do Trombetas, que cerceia as possibilidades de reprodução dos negros, mascara a poluição dos lagos e os permite aparecer como conservacionistas (ibid.: 205-6). O segundo projeto é implementado pela Empresa Mineração Santa Patrícia (do multimilionário Daniel Ludwig, o mesmo do Projeto Jari), negociada com a ALCOA em 1981, que logo trata de despejar os moradores, às vezes indenizando-os por suas benfeitorias (ibid.: 206). Por último, a instalação de hidrelétricas nas cachoeiras mais distantes do Trombetas ocorre na formação de um "novo polo de desenvolvimento", a despeito da caracterização mítica das cachoeiras pelos pretos (ibid.: 207). O resultado é a "desestruturação da vida econômica e social dos moradores próximos" (ibid.: 206), em diversos sentidos discutidos no capítulo de encerramento do livro, como a quebra da exploração da castanha, o aumento da necessidade de dinheiro e da venda de força de trabalho para as empresas locais, a interdição da possibilidade de caça e, a depender do local, de cultivar uma roça e ser expulso (ibid., cap. 5).
} 
254 e do PIC Monte Alegre, além da instalação da Comara ${ }^{96}$, indústria de calcário, em Monte Alegre (ibid.: 48). Em virtude das ofertas de emprego derivadas de projetos de Estado, houve um "deslocamento de pessoas para fora do setor agrícola", migrando para as cidades, garimpos e entornos de grandes projetos. Em Monte Alegre, a população urbana teria crescido consideravelmente, em vistas do emprego no comércio, não obstante em menor proporção que os municípios-alvo de projetos industriais, e jamais ultrapassando a população rural (ibid: 48). As migrações centraram-se em torno do PIC, com grande contingente trazido do Nordeste e de municípios próximos, mas também com estabelecimento de famílias já residentes naquelas localidades (ibid.: 49). Ao assentamento acompanharia políticas de valorização à produção agropecuária, conduzindo ao alargamento do rebanho e à concentração fundiária, que se fizeram através de inovações técnicas e da disponibilização de crédito (ibid.: 50-2). Notadamente, da época, resulta o motor de beneficiamento de mandioca, a incrementar a produtividade de farinha, tal como a introdução de motosserra, que acelera a ocupação de terras e a formação de $\operatorname{pastos}^{97}$ (ibid.: 53-4). Já o crédito ofertado, ainda que esporádico, resulta na difusão da criação de gado e, no custeio das famílias recém-assentadas no PIC, na expansão de culturas de ciclo curto, como a banana branca (ibid.: 53).

As consequências relativas à implantação do PIC nas relações de produção na área têm sido pormenorizadas ao longo deste capítulo. Numa escala em que se inscreve a Amazônia, o diálogo com diversos autores nos permitiu acessar, de maneiras distintas, uma ruptura, por assim dizer, com formas endógenas de reprodução, em consequência da assim chamada “integração nacional” e industrialização. Hébette e Marin (1981) sintetizam na "expansão do capitalismo" estes processos, pensados por Graziano da Silva (1982), por sua vez, mediante a pergunta do "fechamento" da fronteira. Ianni (1979) destaca uma política fundiária nacional na distribuição da população trabalhadora rural entre diferentes regiões do território, enquanto Baumfeld (1984) esposa tais políticas pelo prisma da mobilização do trabalho na fronteira. Velho (1979) reúne no projeto de capitalismo autoritário brasileiro a subordinação do

\footnotetext{
${ }^{96}$ A Comara é uma empresa sob o controle da aeronáutica brasileira. A sede está localizada na saída do perímetro urbano de Monte Alegre, e as jazidas, próximas à gleba Mulata. Ela esteve em plena atividade na década de 1980 e, quanto à atualidade, dispomos de poucas informações. Alguns dos interlocutores com quem convivemos sempre ressaltavam ocorrências de calcificação dos pulmões dos ex-empregados da companhia, amiúde já falecidos.

97 "Através dela [motosserra], o ritmo de exploração das matas dos lotes foi alterado por aumentar a possibilidade de abrir áreas maiores de roça, diminuir o tempo e o esforço de trabalho e aumentar a produtividade do trabalho familiar [...] Entre 78 e 96 estima-se que tenha havido um acréscimo de $150 \%$ no tamanho dessas áreas, assim como se estima que, da área aberta, aquela destinada à implantação de pasto aumentou de $9 \%$, em 1986, para 20\%, em 1996" (Oliveira, 2002: 54).
} 
campesinato aos ditames da acumulação, algo que, para Martins (1975), configura uma mudança no regime de acesso e usufruto da terra, por meio da regulação desta.

Parece que os autores por nós inventariados, guardadas suas diferenças, também se reportam a condições de formação de um mercado de terras e de trabalho mobilizados nacionalmente. A partir dessas leituras, traçamos um caminho interpretativo de modo a situar que força de trabalho circula pelo território com fins à valorização autorreferente de capital. Força de trabalho também integra o que Marx denomina de "superpopulação relativa" às necessidades da valorização, como massa humana supérflua e subsidiária disposta a ser explorada (Marx, 1. I t. II, 1986, cap. XXIII, item 3). Em nosso contexto, pode ser que tenhamos o arranjo de uma superpopulação formada no Nordeste, consoante à pretensa indisponibilidade de terras, deslocada para os projetos de colonização na Amazônia. Seria força de trabalho ${ }^{98}$ a ser empregada na expansão da fronteira e na conseguinte intensificação da grilagem e de operações de compra e venda de terras, que resultam em expropriações e na concentração fundiária. Nesses termos, a fronteira funciona como locus da formação de um mercado nacional de trabalho e de terras. Daí, o que significa para o produtor possuir terra? Em que medida esta provê a subsistência, diante da instituição da necessidade progressiva, embora contraditória, de venda de força de trabalho em troca de dinheiro? No caso, o dinheiro passaria a intermediar relações que antes dependiam da união do produtor a seus meios de produção. O processo de monetarização das relações sociais é, no texto, argumentado da perspectiva da territorialização do capital segundo um projeto de modernização recuperadora. Por intermédio do planejamento, o Estado busca promover condições capitalistas de produção contra as formas regionais de reprodução, com o sentido da autonomização entre terra, trabalho e capital como fatores de produção mobilizados em mercados regulados no território nacional. Nessa região da Calha Norte paraense, o exame de condições da formação contraditória do mercado de terras e de trabalho, da urbanização da fronteira e da institucionalização do Estado, desde as políticas executadas em torno do PIC Monte Alegre, nos permitiu conduzir ao esboço da pergunta do sentido das transformações das relações de produção nesta área. As políticas de Estado se estabelecem, sobretudo, pela investida na titulação da terra e na oferta de créditos bancários. Para resgatarmos uma passagem do

\footnotetext{
${ }^{98}$ Em Baumfeld (1984), retomemos, a superexploração é a forma com que se dá a acumulação no contexto de formação da população trabalhadora em países de industrialização recente, sendo a peonagem um caso particular observado nas áreas de fronteira do sudeste paraense. Lembremos também que, em nosso caso, argumentamos a formação contraditória de um mercado de trabalho na Calha Norte paraense por intermédio da diversificação da mobilidade do trabalho, na qual a necessidade do equivalente - decorrente da monetarização decorrente de políticas públicas - coage o trabalhador a dedicar-se à remuneração intermitente (em diárias, no garimpo, no emprego em grandes projetos) embora ele permaneça dono de seu lote de terra.
} 
programa operacional do Incra (1975: s/p), o emprego de "métodos rudimentares" pela "agricultura de subsistência" deve ceder espaço a "um desenvolvimento econômico das culturas". A questão não varia entre a avaliação do sucesso ou do fracasso dos planos, senão de como a elaboração e a execução de tais políticas foi, a seu modo, autonomizando o capital em distintos fatores de produção. Se, por exemplo, a titulação da terra é demasiado demorada, ou se nem mesmo chega a ocorrer no sentido de assentar famílias de lavradores, fica aberta a possibilidade de a terra ser mobilizada num mercado a dinheiro. Igualmente, se a população da área investigada não fora exatamente submetida ao trabalho assalariado, isso não deixa de estar vinculado a outros momentos característicos de reprodução do trabalho no capitalismo, inclusive como dinâmica regional. A circulação de dinheiro funciona mais profundamente como fonte de mobilização da força de trabalho de indivíduos buscando retornos monetários. A contrapartida, claro, está na possibilidade ainda aberta de possuir um lote de terra e em práticas como o escambo, que descrevemos anteriormente. Estes fatores dão uma aparência de continuidade ao processo, a ponto de relativizar ou escamotear a tese do corte com as formas regionais de reprodução.

Uma vez que tal projeto de modernização tende a homogeneizar ou destruir a região econômico-política tal como apresentada por Chico de Oliveira (2008), a noção de região não deixa de persistir, se bem que agora, opinamos, incline-se a acomodar-se num rótulo de região de planejamento. Os debates gerados por políticas territoriais instituem a Amazônia e a Calha Norte paraense como superfície de intervenção, isenta das relações sociais de produção do espaço, e na qual se alocam fatores de produção. Desse modo, a noção de região esposada confunde sua função instrumental com a noção em si mesma, o que a geógrafa S. Lencioni (2014: 202-3) localizaria como fruto de uma impropriedade teórica e metodológica.

Há ainda uma guinada de orientação entre o modelo de planejamento representativo desse período e o que virá a partir de meados da década de 1980, com a crise fiscal do Estado e a regulação de formas relativamente diferenciadas de investimento de capital e de mobilização do trabalho e da terra componentes de um processo crítico de acumulação. As transformações daqui vigentes, tomadas a partir de observações empíricas, permitem repensar as formas acima assinaladas da territorialização do capital. Exige-se um capítulo à parte. 


\section{CAPÍTULO 4}

CONFLITOS E TRANSFORMAÇÕES RECENTES NA FRONTEIRA DA CALHA NORTE PARAENSE

Ao longo dos capítulos que ora compõem nossa dissertação, tencionamos apresentar um movimento de territorialização do capital na fronteira da atual Calha Norte paraense, cujo sentido é a formação de terra, trabalho e capital como mercados aparentemente independentes e regulados pela esfera política do Estado. Se, grosso modo, localizamos a fronteira segundo o roteiro do apossamento de terras por lavradores autônomos, mostramos como essa autonomia é mediada por formas particulares de coerção do trabalho na extração do excedente que repõe as dinâmicas regionais (Oliveira, 2008) da área. A institucionalização do Estado, por seu turno, é tomada mediante a busca por presidir a violência exigida na mobilização do trabalho (Gaudemar, 1977) num território do Estado nacional, parte de um projeto de modernização determinado pelo desenvolvimento global do capital. A territorialização do capital significa também a autonomização do Estado de suas relações regionais.

Desse modo, buscamos expor o processo de autonomização de maneira contraditória, a partir de um traçado histórico. No primeiro capítulo, a fronteira é mote da contradição entre Estado e região, ambos em formação e reiteração, em suas formas de ordenação do acesso a terra e do controle de força de trabalho na área. No segundo, a fronteira é apresentada como contradição em processo da produção de mercadorias e reprodução dos sujeitos, determinadas por um armazém, bem como da espontaneidade do posseamento de "terras livres", que se traduz como subsistência e dilatação territorial da comunidade pesquisada. No terceiro, exibimos como junto à expansão da fronteira começa a operar, progressivamente, um mercado fundiário, e os agricultores passam a mobilizar sua força de trabalho mesmo que de posse da terra ou com possibilidade de abrir novas ocupações floresta adentro. Fomentando o processo, o Estado vai juridificando a propriedade fundiária e edificando infraestruturas, levando-nos a suscitar a incógnita da dissolução das relações regionais em vistas de padrões de produção impostos nacionalmente, na circulação aparentemente autônoma de mercadorias no território. E com a mobilização das categorias capitalistas no mercado, onde se engaja a fronteira investigada no contexto de transformações recentes na dinâmica capitalista?

Procedendo da indagação, começamos (cap. 4.1) captando a dinâmica da rotatividade da terra na área, que, primeiramente justificada por óbices com documentação, pressupõe o imperativo gradual de dinheiro a ser investido na terra para ampliar e diversificar a produção e 
concorrer no mercado. A concentração fundiária, o outro extremo do processo, conduz à expansão da fronteira até a demarcação de um cinturão de áreas protegidas que à primeira vista encerra a posse de "terras sem dono", embora revele outras estratégias de mobilização da terra. Já a alternativa do êxodo rural é interpretada como parte dum processo mais abrangente de monetarização encampado por políticas de assistência e pela diversificação do consumo, realizando-se tanto no campo como na cidade. A monetarização mobiliza e diversifica a força de trabalho, com especial intervenção do crédito, o que nos permite delimitar processos de expropriação como autonomização do trabalho da terra.

Prosseguimos abordando, no cap. 4.2, como o crédito previsto pelo planejamento é apreendido positivamente nas ciências sociais. Confrontamos as teorias explicitando em seus discursos a gestão flexível da população por parâmetros de produtividade e "desenvolvimento sustentável" que naturalizam a expropriação enquanto imprimem a aparência de manutenção de uma reprodução familiar não plenamente mediada pelo mercado, mas por necessidades estabelecidas pela própria família.

No cap. 4.3, esta simulação de continuidade com formas regionais de reprodução é cotejada com a apresentação dos conflitos no Projeto de Desenvolvimento Sustentável (PDS) Serra Azul, limítrofe a duas florestas públicas. Exibimos aqui a grilagem de terras e a extração ilegal de madeira na comunidade, em contraposição aos lavradores que reivindicam a regularização do assentamento. A reprodução dessas personas é, entretanto, mediada por mercados autonomizados e pelo Estado, que é incumbido da organização da apropriação da terra, conduzindo-nos à comparação das diretrizes do Programa Terra Legal com as do PDS. Visto que os grileiros são proprietários vindos do sudoeste do Pará, vinculamos seu deslocamento ao avanço da fronteira no eixo da rodovia BR-163 Cuiabá-Santarém: o processo é norteado pela exploração madeireira e pecuária, que se vale de artifícios candentes de violência para abrir terreno para a instalação do cultivo de soja.

Terminamos por retomar, no cap. 4.4, que as Unidades de Conservação (UC) da Calha Norte paraense, em lugar de corroborarem com o "fechamento" da fronteira, apontam para outros mecanismos de uso da base fundiária. O discurso legitimador da conservação é sobejamente respaldado no "desenvolvimento sustentável", que direcionamos para a querela de mudanças recentes na reprodução capitalista global e para a função do Estado no processo. Problematizamos a postura do Estado na regulação da fronteira afrentando a prática da conservação, que baliza a noção de necessidade de reiteração da acumulação primitiva, com a crise fundamental da valorização capitalista e de suas categorias e instituições mediadoras. 
Aqui, as ações estatais tendem a se reverter em políticas de confinamento territorial da população.

\subsection{Processos de expropriação e os limites da posse da "terra liberta"}

Uma reportagem assinada por E. Maria, publicada em 1995 na Folha de São Paulo, destaca a relação existente entre a ausência de documentação, a venda e a transitoriedade da posse fundiária ${ }^{99}$. É Informado que segundo o Incra, 16,34\% dos colonos do Projeto Integrado de Colonização (PIC) Monte Alegre passaram adiante seus terrenos "nas últimas décadas" (Maria, 1995). Todavia, “na prática [...] a rotatividade dos lotes é muito maior”, de sorte que:

A maioria dos lavradores entrevistados [...] disse ter comprado a terra de terceiros. Muitos têm dois, três e até seis lotes de terra. Alguns lotes já estão nas mãos do quinto ou sexto dono. O governo tem obrigação legal de controlar o usufruto dos lotes até a entrega do título definitivo de posse para o assentado - e, neste caso, ainda não foram entregues mais de mil títulos. Mas o Incra não tem meios eficazes de controlar as transações com os lotes, que variam de 25 a 100 ha.

Com a expressão "últimas décadas" fica vago o intervalo histórico a que se refere a venda de terrenos no local. De resto, o fragmento explicita a rotatividade e a concentração relativa de terras, como agregação de parcelas que não excedem 100 ha. A incumbência da intensificação da fiscalização é delegada ao Incra, não obstante alegada ineficácia na emissão de títulos de posse e no controle das transações.

Prosseguindo, consta no artigo a presença de 4025 famílias e de 1347 lotes ociosos no projeto, na época. A rotatividade teria como consequência o êxodo para a cidade, aguçando a ocupação de bairros pobres como Terra Amarela. Enquanto isso, o assentamento é descrito a partir de elementos como a falta de energia elétrica - salvo o perímetro urbano das glebas -, de mecanização da produção e de assistência técnica para os colonos, além de se persistir fatores como a escassez de médicos e remédios e de professores e material escolar, resumidos aqui como "abandono" pelo Estado. Apesar dos óbices, o PIC sustentava Monte Alegre como o maior produtor de milho e feijão do Pará:

\footnotetext{
${ }^{99}$ E. Maria. Assentados vendem lotes no PA; Incra de diz incapaz de fiscalizar. Disponível em: <www1.folha.uol. com.br/fsp/1995/12/31/brasil/19.html>. Publicado em: 31 de dezembro de 1995. Acesso em: 01 de agosto de 2018.
} 
A UAC [Unidade Avançada de Colonização do projeto] responde por $80 \%$ da produção agrícola do município. $\mathrm{O}$ assentamento produz principalmente milho, feijão, banana, arroz, mandioca, farinha de mandioca e pimenta-doreino. Também há um rebanho estimado em 80 mil cabeças de gado, além da plantação, em menor escala, de hortifrutigranjeiros.

Ponderamos que a postulada esterilidade do Estado pelo jornal, a partir da ineficácia da fiscalização e com o abandono da assistência ao PIC, indica antes uma forma de atuação das políticas territoriais do que precisamente uma falta. Nada confirma que a regularização da terra estanque a comercialização. De toda maneira, que todos se reconheçam como iguais proprietários no mercado parece assegurado por uma força acima da sociedade. A diferença do caso, possivelmente, é que as transações só eventual e lentamente são autenticadas em cartório. Mas mesmo esse modus operandi é algo inválido caso comparado a hoje, quando outros documentos são mais relevantes na garantia de direitos de propriedade, como veremos. Ainda assim, aparenta persistir na área grande confusão acerca da titulação de terrenos, que corrobora especialmente na profusão do mercado fundiário. Importa reter que essa confusão é um fator entre outros na transitoriedade da posse, mas não é o resolutamente responsável.

Vejamos que a certa altura de nossa conversa com Miguel, apresentado no capítulo passado, ele esmiúça o trato demandado com o solo, explicando a coivara e declarando, em seguida, não ter "ânimo" para plantar, por seu pai jamais ter registrado o terreno:

Miguel: E essa terra aqui, não me animo pra plantar, fazer um limoal, uma coisa, que papai nunca cadastrou isso. E aí hoje eles exigem o cadastro pra ti vender. E cadê o cadastro? Eu não tenho. É dele, né?

D.L.: Ele comprou aqui?

Miguel: Foi, comprado. Mas não é cadastrado. Aqui não tem CAR de terreno.

D.L.: Vocês já foram atrás disso? Quer dizer, seu pai?

Miguel: Eles vieram aqui com ele, pra fazer. Mas é que eu não tava aqui. Aí não foi feito o CAR, nunca foi feito. E esse terreno não tá no nome do papai.

D.L.: Tá no nome de quem?

Miguel: Esse terreno ele comprou de uma mulher. Ela já morreu. Aí o papai não pode mais fazer isso aí, né? Diz que ele não pode, eu não sei. Nunca procurei saber. Isso aí tem que fazer no nome dum filho, parece.

D.L.: Mas e a mulher lá, que era a dona do terreno?

Miguel: Ela já morreu. Só tem um filho.

D.L.: Mas não precisa passar mais por ela? 
Miguel: Não, porque aqui, no caso quem, ele vai fazer o CAR, né? Aí não existe mais, porque na época era título, né? Aí papai tem só o coisa de compra e venda. Foi passado no cartório, carimbado no cartório, né. Que ele pagou isso aqui, né. Aí mas não tá no nome dele, o título não tá no nome dele, porque naquela época foi parado. De primeiro, tu pagava o título, né? A gente pagava uma taxa por ano. Aquela época, eu não sei, era $\mathrm{Cr} \$ 12$ que pagava. Não tô bem certo. Aí nunca veio acho, pra ele pagar, não foi mais procurado. Aí foi quando acabou o título e hoje só é CAR, né, não existe mais título. Aí o do papai não vale mais. Papai nunca procurou, nunca foi atrás disso.

Seu pai nunca ter demonstrado interesse pelo pagamento da titulação talvez esteja vinculado à própria conjectura da fronteira "aberta", levando-nos à interrogação do que seria, aqui, a terra. Seria forçosamente preciso, para o lavrador, solver anualmente uma taxa, ao passo que podia se apossar "livremente" de áreas floresta adentro? Mesmo com a regulação dos terrenos, nada impede, senão até motiva, conforme temos examinado, a transação e o avanço da ocupação de terras.

Apesar de tudo, as estratégias na regulação da terra também vão se modificando, aqui mostrada a exigência do Cadastro Ambiental Rural (CAR) como registro de informações para a legalização ambiental dum imóvel rural. O possuidor do documento é desobrigado a averbar o terreno em cartório e pode acessar programas de apoio à conservação ambiental e de obtenção de crédito e seguro agrícolas, além de ter isenção de impostos para recuperação de áreas e permissão para aquisição de insumos e equipamentos ${ }^{100}$. Nesse sentido, a posse do CAR, de um lado, dispensaria a regularização da terra exclusivamente junto ao Incra ou ao instituto estadual de terras - no caso, o Instituto de Terras do Pará (Iterpa) - para que se tenha garantida uma ordem de direitos. De outro, consistiria em mais um entrave para a reprodução do lavrador em seu lote ${ }^{101}$. Inclusive, é a ausência desse registro o motivo da queixa de Miguel; algo que, para ele, o impede de alargar e diversificar a produção:

Miguel: Aí, no caso, se eu fizer uma terra, dessa mexida, pra tu tirar duzentos saco pra acima, eu tenho que ter CAR, porque eu não vendo na cidade. Agora eu ainda vendo, produto mexido eu ainda vendo, né. Eu vou lá, converso com quem, e ainda vendo, um saco pra um, um saco pra outro eu vendo.

\footnotetext{
100 <http://www.car.gov.br/\#/sobre>. Acesso em: 02 de agosto de 2018.

${ }^{101}$ Se convocássemos a vigilância ambiental ostensiva ou arbitrária o debate se intensificaria. Com frequência, os lavradores reclamam de multas por degradação ambiental que extrapolam até o preço cotado para seus terrenos. O mais usual é que a multa seja enviada aos imóveis identificados por satélite com focos de calor, mas quem incendeia a área pode ser um vizinho. Daí, os produtores devem recorrer diversas vezes à Justiça para renegociarem e rebaixarem significativamente a dívida contraída.
} 
D.L.: Então, como que é: você vende um pouco pra cá e...

Miguel: É. Eu vendo mais na roça, né, a farinha, pra vender.

D.L.: Por aqui perto? E leva?

Miguel: Por aqui e pela cidade mesmo, eu, a mulher, a gente leva pra vender em Monte Alegre aí. Mas só que no caso, eu não posso tirar uma mercadoria pra fora como essa pra vender. Eu não posso. Só se alguém... tipo de tu tiver uma firma registrada [...] A mesma coisa é o limão: se tirar duzentas caixa de limão, se eu não entregar pra um vendedor aqui dentro, pra um atravessador, agora. Se daqui uns dias tu não tiver CAR, nem pro atravessador tu vende.

Nessa conjunção ao menos, o CAR serve para mediar a produção e a comercialização de gêneros agrícolas com um corte de viés ambiental, o que pode ser compreendido como postura do planejamento na regulação do mercado e da terra como mercadoria. $O$ entrevistado, por não deter o documento, restringe suas vendas à vizinhança e à cidade, onde basicamente todos se conhecem. Descontado "um saco para um, um saco para outro", a produção, que não pode ser efetuada em grande escala, é fornecida para o atravessador.

O produtor não atinge o consumidor final e se percebe prejudicado na comparação de preços nas distintas fases da circulação de um mesmo bem. Como declara o irmão de Miguel, Dó, o marreteiro ${ }^{102}$ e os comércios "tão pagando bem menos que antes". Dó costuma vender milho e farinha na cidade, a preços que ele considera baixos, para atravessadores do Bosque (a feira); outras vezes, repassa a produção em seu lote, com desconfiança: "quando o marreteiro vem pra cá, é porque na cidade o preço da farinha tá bom”. Em geral, Dó vende a saca de farinha a uma cifra entre 20 e 30 reais, enquanto transfere o milho a montantes entre 25 e 30 reais, variáveis de acordo com o período do ano. É no decurso da colheita, claro, que o grão fica mais barato.

Relações com atravessadores estão longe de ser novidade na área. Ao regressarmos a um contexto de relações centralizadas no armazém, o abastecimento do lavrador, em produto, é intercambiável, com um lapso temporal, com a produção agrícola, ocasionalmente restando alguma quantia em dinheiro. Aqui, o próprio comerciante é um intermediário, ou se temos em mente o marreteiro, existe uma competição provável pelo sistema de fornecimento (cap. 2). A singularidade atual, salvo engano, está na frequência do pagamento da produção em dinheiro, à vista ou "na folha" - ou seja, adiantado, quando o produtor cultiva um quantum

\footnotetext{
${ }^{102}$ Um mascate que, se antes viajava no lombo de mulas, hoje possui moto ou camioneta, ampliando o alcance de suas atividades e reduzindo o tempo exigido para contatar o cliente. Significa que as relações nesse quesito, obviamente, são mediadas pelo desenvolvimento das forças produtivas da sociedade.
} 
predeterminado pelo comprador. A forma universal do equivalente indica que o metabolismo social do mercado (Marx, 1. I t. I, 1985: 94), na equiparação de tempos de trabalho, media a relação. Ainda assim, a desigualdade de preços perante a cidade, por exemplo, persiste. Igualmente, tal oscilação tende a indicar a concorrência entre produtores: quem produz mais, vende mais, mesmo que barato. Por extensão, quem produz na entressafra vende mais caro, malgrado aqui a produção dependa cada vez mais de investimentos na terra, a começar pelo próprio licenciamento do terreno, e na forma de insumos, irrigação, meios de estocagem, etc. Dito com outras palavras: restringindo-se a possibilidade de incremento da produção, esta não poderia depender integralmente de irregularidades no registro fundiário, revelando a gradual necessidade de dinheiro para se produzir em maior escala ${ }^{103}$ e competir no mercado.

O outro lado da rotatividade da posse, como apontado pela reportagem da Folha, é a concentração de terras. Na Canp entrevistamos Jairo, um gaúcho residente desde 2003 em Monte Alegre. Quando lhe pergunto onde há maior concentração fundiária no município, ele dá uma resposta alusiva ao setor que viabiliza o processo: a pecuária, o que já não é novidade.

D.L.: E onde tem mais concentração de terra aqui em Monte Alegre?

Jairo: Hoje vai na pecuária, né. Aqui, é que nem falo pra você: tem as terra aqui, são todas pequenas, de 25 ha. O que tá a venda aqui, é normal isso, aconteceu lá pro Sul, o que tá havendo pra lá é concentração. Aqui, o pessoal do Zé Amaro, que tem umas 2 mil, 3 mil e poucas cabeça, eles tão é abocanhando tudo. Vão comprando do vizinho, vão comprando tudo. Então, tem uma concentração de terras, né. O pequeno não sobrevive mais, cara.

Antes de chegar à área, Jairo mora no Paraná e por catorze anos em Sinop, no norte de Mato Grosso, de lá migrando para Nova Mutum, uma cidade próxima. Segue por fim para Santarém, onde fica por dois anos e mantém uma empresa de perfuração de poços. Portanto, ele está longe de ser um pequeno produtor ${ }^{104}$, e ainda compra terras para extração de madeira numa área limítrofe a uma reserva ambiental:

D.L.: Aqui em Monte Alegre você tá vendo isso?

Jairo: Tô. Se tu pega e sai, eu saio mesmo. Eu tô mexendo com uma madeira, eu tenho umas terra aí que daqui dá uns $140 \mathrm{~km}$. Tô tentando tirar madeira lá; tenho casa de serragem... tá meio devagar lá, né. Mas nesse lugar, faz uns

\footnotetext{
${ }^{103}$ A retomada de uma fala de Miguel do capítulo passado serve para ratificar os problemas agora levantados: "Pois é. Aqui mesmo nós não tem mais produção. Aí por falta de que? Por falta de dinheiro. O que que falta aqui pra nós? Nessa área aqui de terra, vai daí até bem aí assim pra lá, uns bom pedaço aí, muito boa pra mecanizar. Mas a gente não tem... eu não tenho condição".

${ }^{104}$ É a condição de muitos sulistas emigrados para a Amazônia mais ou menos recentemente, como será visto.
} 
cinco, seis anos que comecei a comprar, né. Lá na divisa, quando começa a reserva já, né [...] tô no Perímetro, na mesma área lá. Só que daí, entra pelo Limão, né. Ali tem um tal de Rabo Assado, que é a comunidade de Novo Horizonte, ali, eu comecei a entrar ali faz uns cinco anos, mais ou menos. Tinha 27 famílias morando lá; hoje, tem três, e tem um lá que tá só esperando a mulher parir, que vai pra Serra Azul. E um outro, que é um conhecido meu, o Seu Jorge, da Dona Rosa, ele tá com um problema sério de coluna, e daí não tem mais transporte, não tem mais nada pra lá. Então são mais dois ali que estão pra ir embora. Então, quer dizer, de 27 tem três famílias. Houve um abandono. E se tu anda, no Perímetro, do Limão pra lá são $70 \mathrm{~km}$, entrou energia agora, foi até o rio Jauari, tem energia e tem tudo. Eu tenho certeza que $60 \%$ das casas ali (são 100 ha, né), 60\% das casas ali estão abandonadas. Tem a pecuária, né, tem um gadinho, mas ninguém mora lá. Tá havendo concentração; um vizinho compra do outro e vai tendo concentração de áreas.

O mais chamativo em sua fala, decerto, é a reorganização da fronteira: em Novo Horizonte, comunidade adiante do Limão, a população é rapidamente reduzida e boa parte das casas é abandonada, ocupando-se os terrenos com gado. Efetuando uma retrospectiva, testemunhamos na margem esquerda do Baixo Amazonas, desde o fim do século XIX, a execução de medidas voltadas à colonização e regularização da terra, chegando, em 1971, à fundação do PIC Monte Alegre. Acompanha este projeto, com o assentamento de famílias já residentes na área, a construção da PA-254, a transação de lotes e a concentração fundiária. Os lavradores sem terra, ou por vendê-las ou por serem recém-instalados, encabeçam a dilatação da fronteira, com a fundação de novos grupamentos rurais rumo nordeste, sempre mais ao interior da floresta. No cap. 3.1.2, discutimos como Becker (1982: 119-22) analisa a formação dos povoados como locus de organização da força de trabalho no desbravamento de áreas, antecedendo a chegada de grandes proprietários que ensejam a extinção de comunidades e o reaparecimento destas em pontos mais distantes. Em nosso caso, vimos como são proprietários de médio porte - se bem que possuidores de dinheiro em um contexto em que este começava circular mais constantemente na área -, e até então oriundos da própria região, que coagem à reiteração da dinâmica dos agrupamentos. Se agora estamos lidando com as formas mais recentes desse processo, notamos uma expansão na fronteira que, em primeira instância, parece ter seu limite relativo na demarcação da reserva ambiental.

$\mathrm{Na}$ entrevista com Jairo, os óbices que incentivam o "abandono" - que pressupõe a venda, como ficará mais nítido - da terra são veiculados às condições técnicas, propondo-se a 
defasagem da agricultura e do funcionalismo estatal, a falta de conhecimento técnico e a lentidão na regularização fundiária ${ }^{105}$. Para lá do desapreço presente na fala do interlocutor, ele introduz o parecer de que, sem aplicação das técnicas, cujo fim é o aumento da produtividade do trabalho, uma sorte de cultivos tem malogrado em favor da especialização na pecuária. Em Monte Alegre, assim acontece com a bananicultura ${ }^{106}$ e, mais tarde, com o milho e o tomate:

Jairo: Aí, da parte do milho, foi muito milho aí, cara. Tomate, foi tirado muito tomate, mas tudo na experiência, assim, do produtor, do cara que produz ali, e não existe nem uma assistência nem nada, tanto é que já parou de se produzir o tomate por causa de doença que deu. Foi dando doença, os cara não consegue controlar e para. Aí sempre eles vão tentando em áreas novas, né cara. Ali no Perímetro mesmo, foram indo. Lá nesse Rabo Assado, onde eu tava, tem uns cara ainda que planta. A doença ainda não chegou lá, mas é questão de dias. Lá é o que eu falo pra você, era uma região assim, de mata, terras boas, bem fértil, bastante água.

D.L.: Isso é gente do Limão que foi abrindo terra pra lá?

Jairo: Foi, foi. Pessoal foi indo, né. Vai indo, vai indo, e aí criaram aquela reserva, que barrou, né. Se não, o pessoal taria um pouquinho mais pra frente. Mas tem muita área. Hoje, aqui em Monte Alegre, tem muita terra. Depende muito de recuperação de área.

D.L.: Aí é tudo área de pasto...

Jairo: Tudo área de pasto. Quase não existe mais plantio, e vira pasto, só que tão virando áreas abandonadas, né, cara. Que vamos dizer: o pasto aí, tem muita área que é 20\%, 30\% da área, cercada tudo. Mas a juquira tomou de conta, né. Então, quer dizer, hoje é aproveitado muito pouco da área [...] Aí esse produtor, ele foi se acabando, né, como diz a história. Ele foi vendendo gadinho, vendendo, vendendo, e aí ele tá chegando numa situação assim; que a cerca dele tá acabada, o pasto tá enjuquirado, a parte de documentação, que aí eu falo pra você, não procurou se regularizar, aí não consegue tirar financiamento pra recuperação no banco, não tem mais o gado pra fazer a recuperação por conta própria, e aí que ele acaba abandonando. Aí que entra o

\footnotetext{
105 “Tá bem atrasado a agricultura, tá defasada. O pessoal espera o poder público, mas essa Emater aí, não falando mal, mas o pessoal é bem defasado. Então, conheço muitos aí que se arrebentaram mais ainda. Não há conhecimento técnico. Tem o problema sério da escritura [...] A regularização aqui é muito devagar."

${ }^{106}$ Sobre a rápida duração da cultura de banana na área, os moradores imputam o incentivo dado pelo crédito do Banco do Brasil entre os anos 1980 e 1990, freado com o acometimento das bananeiras com a sigatoka negra. Faltando serviços de extensão rural, segundo eles, a produção é abandonada. M. Oliveira (2002: 53) chega a abordar o caso superficialmente ao comentar as políticas de crédito na área.
} 
vizinho dele ou outra pessoa, que vai comprando essa área, vai procurando mecanizar, faz uma recuperação de área e vai saindo, né, vai.

Os terrenos são esgotados seja por acometimentos à produção agrícola seja por dificuldades em recuperar áreas degradadas, acrescido o obstáculo na retomada da produção em novas parcelas de terra. E se não se cultiva, mesmo que pastagem, o terreno é tomado pela "juquira", vegetação daninha, o que é especialmente visível nas porções do município de ocupação mais antiga, onde estão seus primeiros núcleos de colonização (Fig. 8). Em compensação, quem possui dinheiro compra a terra e a repara.

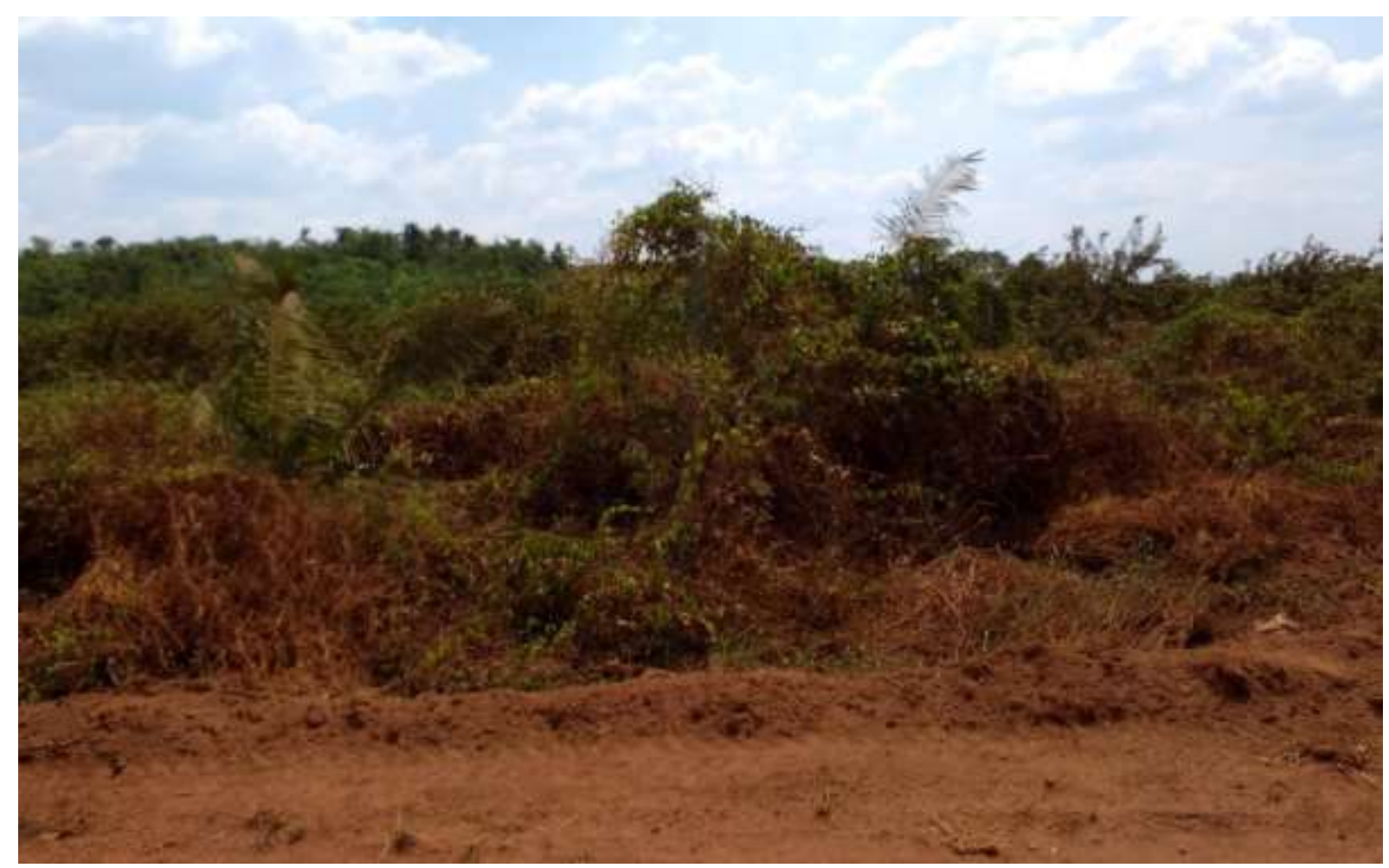

Fig. 8. Mata “enjuquirada” na Serra do Itauajuri.

Indagamos se assim se ratifica uma disputa pela terra regulada pela capacidade de nela se investir, configurando um cenário determinado pela concorrência. Marx (1. I t. II, 1986: 196) assinala como a ampliação da base da riqueza social é concentrada e repartida entre os capitalistas ao mesmo tempo que origina a expropriação mútua entre eles, como centralização do capital. A concorrência que funda esse processo é conduzida pela viabilidade do barateamento de mercadorias, isto é, depende da produtividade do trabalho, que por sua vez depende da escala da produção (ibid.: 196). Embora não estejamos tratando de capitalistas stricto sensu, duas anotações são daqui relevantes: a primeira é que a grandeza do capital 
investido num negócio determina o grau de produtividade do trabalho, e a segunda aponta para a expropriação e absorção dos trabalhos menos produtivos pelos capitais maiores.

Derivando o raciocínio com discussões do livro terceiro d' $O$ capital (id. 1. III t. II, seção VI), a terra passaria a ser mobilizada no mercado embasada nos rendimentos que dela se pode auferir, sobretudo do investimento capitalista. Nesse sentido, a mediação do capital na relação com a base fundiária, em tendência antitética ao trabalho direto com a terra, significa autonomizar as categorias do capital do produto do trabalho camponês (ibid., cap. XLVII) ou da região. A concorrência mobiliza a terra de dois modos: por sua fertilidade e localização, e, progressivamente, por níveis desiguais de aplicação de capital, regulados pela produtividade social do trabalho. Tais formas correspondem, respectivamente, às rendas diferenciais I e II.

Em decorrência disso, fica sugerida uma abordagem para a perda de posição de Monte Alegre como maior produtor de milho e feijão do Pará, com seu cultivo predominantemente manual face à mecanização da produção noutras porções do estado. E não só. A concorrência, aprofundando a dependência reificada do dinheiro, mantém tanto o produtor pauperizado em sua terra quanto se direciona para a expulsão e estratificação fundiária na fronteira, compelindo à posse de novas “terras sem dono” ou à migração para a cidade.

Só que, a princípio, o primeiro recurso é vetado pela demarcação da reserva ambiental nas bordas das terras mais recentemente apossadas. Consultando o Mapa 3, a Unidade de Conservação (UC) a que Jairo se refere, limítrofe ao Perímetro e de onde extrai madeira, é a Floresta Estadual (Flota) do Paru, fundada em 2006. Em 2010, a Flota lança seu plano de manejo, apresentando a limitação de áreas protegidas como "uma das estratégias mais efetivas e recomendadas para conservar a floresta", a frenar o desmatamento, armazenar estoques de carbono e contribuir na manutenção da biodiversidade (Pará, 2010: 20). A floresta abrange porções de cinco municípios, num total de 3,6 milhões de hectares, compondo o maior mosaico de UCs do planeta ${ }^{107}$ (ibid.: 20). Mosaico que "forma uma zona tampão para conter o avanço da fronteira madeireira e agrícola" (ibid.: 23).

Nas cercanias de projetos de assentamento também se encontra a Floresta Nacional (Flona) da Mulata, localizada nos municípios de Monte Alegre e Alenquer, com 16 601,41 ha. Criada em 2000 com o objetivo de "promover o manejo múltiplo dos recursos naturais"108, não possui plano de manejo, apenas um conselho consultivo de 2011. Há poucas informações à disposição, entre as quais uma nota do Instituto Socioambiental (ISA) quanto a ameaças

107 A Flota divisa com sete UCs: a Norte, a Reserva Biológica Maicuru; a Sul, a Flona Mulata; a Sudeste, a Estação Ecológica do Jari; a Leste, a Reserva de Desenvolvimento Sustentável do Rio Uiratapuru; a Oeste, a Flota Trombetas; a Noroeste, enfim, a Terra Indígena Zo'é e a Estação Ecológica Grão Pará (Pará, 2010: 22).

108 <www.planalto.gov.br/ccivil_03/DNN/2001/Dnn9274.htm>. Acesso em: 14 de agosto de 2018. 
sobre a conservação da floresta, na ordem de desmatamentos, queimadas e mineração industrial $^{109}$.

\section{Mapa 3 - Flota do Paru}

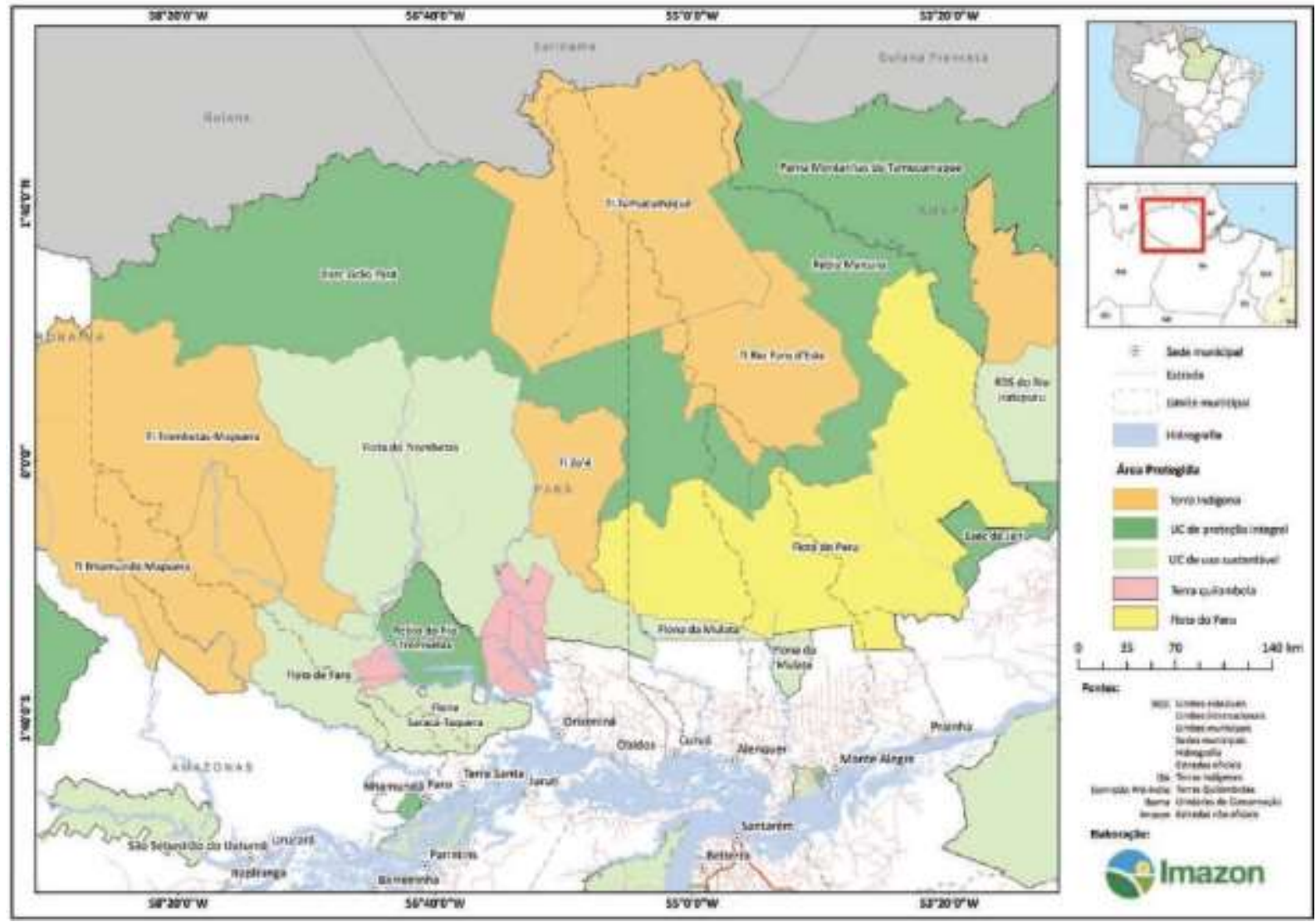

Fonte: Pará (2010: 23).

Ultrapassando um primeiro golpe de vista, contudo, a definição de áreas protegidas deve redundar na praticabilidade de um uso alternativo da terra, se em relação à posse e à grilagem de terras, por exemplo. O Estado centraliza, agora via conservação, o percurso de ocupação da base fundiária, até segunda ordem contrariamente à territorialização da fronteira madeireira e agrícola. Simultaneamente, fica nosso ponto de vista de que a imposição de uma barreira ecológica tenda a acirrar a pressão pela propriedade da terra onde ela já é lotada de assentados e posseiros. No que respeita às parcelas, esboçamos um panorama de pauperização

\footnotetext{
109 <uc.socioambiental.org/uc/4750>. Acesso em: 14 de agosto de 2018. Fora essa, encontramos apenas uma nota de 2015 no site do Instituto Chico Mendes de Conservação da Biodiversidade (ICMBio), sobre a apreensão de madeira no interior da Unidade. Os fiscais encontraram $6 \mathrm{~km}$ de estradas abertos, um trator e toras de ipê amarelo, que pode ser vendido a altos preços no mercado. Disponível em: <www.icmbio.gov.br/portal/comuni cacao/noticias/4-destaques/7039-floresta-paraense-combate-retirada-ilegal-de-madeira.html>. Acesso em: 14 de agosto de 2018.
} 
que pode atingir magnitude tal a ponto de uma comunidade rapidamente se extinguir e ceder seus domínios para campos de pastagem. Até agora, a disputa entre lavradores e relativamente grandes produtores é mediada pelo dinheiro dispensado na compra da terra, expressando inexoravelmente a violência da injunção da forma mercadoria. A mercadoria que é a forma social da mediação, mesmo, adiantando, quando a violência culmina no esforço da eliminação física, como ocorrido no PDS Serra Azul, ao sul da Flota do Paru e a leste da Flona da Mulata (cap.4.3).

Em variação à expansão da fronteira, a migração de lavradores, privados da terra pelo mercado, para bairros de periferia como Terra Amarela pode representar da maneira mais clara um tópico de urbanização desse contingente, até segunda ordem um exército industrial de reserva posto para exploração. Se e em que condições essa força de trabalho é vendida e as relações desse trabalhador com a vida rural poderiam constituir temas de discussão. Nesse caso, para sermos breves, duas trajetórias nos vêm à mente: a primeira é de uma família de lavradores que visitamos de passagem no ramal da comunidade da Linha do Ererê. O marido trabalhava em um pet shop na cidade, e aos fins de semana retornava para lavrar em seu centro. A esposa nos disse que a intenção era poupar algum dinheiro para ser investido no terreno, por ora cultivado apenas com mandioca, milho e feijão. Pois então, parcela nada ignorável da subsistência daquela família provinha do assalariamento, sendo ainda destacável, como acentua a entrevista, os auxílios dispostos pelo Programa Bolsa Família. Aqui, a assistência estatal vai instituindo o dinheiro como forma de mediação entre seus cidadãos, que então acessam bens de consumo e serviços que lhes são internalizados como necessários.

O segundo caso é o de Nobó, que trabalhou nove anos na cidade com construção civil (de pedreiro a carpinteiro, pintor, encanador e eletricista), edificando sua casa e vendendo-a em seguida, embolsando a diferença relativa ao que dispendera na obra. O interessante é ele ter repetido o percurso oito vezes, até comprar seu primeiro terreno no PDS Serra Azul e passá-lo por uma motocicleta, revertida na aquisição do lote onde hoje reside. Nobó, ainda, planeja erguer uma casa na cidade para se hospedar quando preciso; para ele, é quando recorre a serviços como saúde pública e crédito e quando vende sua produção na feira. Possivelmente, nosso interlocutor não concebe o procedimento construção-venda calculando custos de produção do imóvel em termos monetários, esperando a apropriação dum excedente investido numa nova casa, como um pequeno capitalista. Até porque ele residia nessa casa. Mas já era objetivo seu morar no campo? De acordo com o mesmo, sim, dado que "na cidade você amanhece o dia gastando; é pão, é tudo". 
Nos depoimentos, é difícil distinguir entre o rural e o urbano, caso os encaremos nos moldes da polarização campo-cidade. Parece haver algo próximo da imposição de um "modo de vida" no campo pautado na necessidade de mobilizar trabalho para consumir e acessar serviços e mercadorias, o que normalmente é reputado à cidade. Posto de saúde e escola são os primeiros elementos enumeráveis, acompanhados de comércios e do crescimento dos povoados de fronteira, por nós apreciados segundo a ampliação do rol das necessidades levantadas pelos lavradores da área (caps. 3.1.2 e 3.2). A eletrificação expande tal rol, de forma que com a operação do programa Luz no Campo, a partir de 2000, ouvimos narrativas reiteradas de deslocamentos dos centros para a rua, com os beneficiados obtendo uma diversidade de bens que antes não tinham acesso, como televisores e geladeira. Com a eletrificação dos terrenos, já decorrente do programa Luz para Todos, entre 2013 e 2016, aqueles moradores preferem não retornar, uma vez que dispondo de motocicleta logo chegam a seus centros. Sugerimos, por fim, que uma metropolização que ultrapassa a pontualidade da vida na cidade vai se vinculando à monetarização e disseminação de novos padrões de consumo coexistentes à posse da terra ou não, com função crucial do Estado na construção de infraestruturas e em políticas assistencialistas. Igualmente, o acesso ao dinheiro nem sempre generaliza o trabalho assalariado, apesar de passar pelo consumo de mercadorias.

Essa observação não exclui que o êxodo rural seja frequente mesmo hoje, quando Planalto é o bairro de formação mais recente, e onde não raro moram desempregados, funcionários de comércio e mototaxistas sub-remunerados há pouco tempo em Monte Alegre. Sub-remunerados, diga-se de passagem, na medida em que não é assegurada integralmente a reposição das condições da força de trabalho. No caso de Nobó, ele recorre a uma diversidade de serviços também na Serra Azul, onde subsiste com o produto da roça e com "bicos" como pedreiro. No caso, os ganhos são vertidos no consumo de artigos comprados na cidade e no armazém da comunidade. Sugerimos que o expediente, que pressupõe a permanência na terra, aprofunda a conjectura de diversificação da mobilidade do trabalho, que outrora emprestamos de leituras da formação do trabalho na fronteira (cap. 3.2). A diferença que agora postamos tem a ver com a dúvida de como mobilizar o trabalho do lavrador é medida do Estado em relação à acumulação capitalista global recente.

Também no capítulo passado, quando nos ocupamos do programa operacional do PIC Monte Alegre, o crédito era concebido pelo planejamento enquanto capaz de desenvolver a produção regional, malgrado ainda insuficiente (cap. 3.3). Congregado aos empréstimos, a intenção era prestar assistência técnica aos parcelários, mecanizar a agricultura e angariar 
mais membros para a cooperativa da cidade, incrementando o comércio de bens agrícolas. Historicamente, há uma disseminação das políticas creditícias desde os anos 1980, quando o Banco do Brasil provê, na área, incentivos para a produção de mandioca. Na década seguinte, as políticas se amplificam com o microcrédito do Basa, que opera com os recursos do Fundo Constitucional de Financiamento do Norte (FNO). A saber, modificações no programa de crédito consistem em modificações na postura do planejamento, assunto da seção seguinte.

$\mathrm{Na}$ entrevista com Imá na comunidade do Limão, Ceará, chegando mais tarde na conversa, narra a história de um amigo, Antônio Padeiro, e da relação deste com o financiamento do BB para maniva, entre 1987 e 1988. O mais explícito é que Antônio se endivida, pois na competição com outros produtores os preços são rebaixados:

Ele me contou, um dia, eu conversando com ele um dia, me contou que fez financiamento, e pegou pra não sei lá quantos hectare. Aí ele plantou a maniva todinha, da maneira como foi feito tal, e aí quando chegou a época a maniva tava toda boa de trabalho, de colher. Aí não tinha preço. Rapaz, aí ele correu pro pessoal do banco, chegou lá e pediu pra eles conseguir mercado e tal, porque ele queria que se passasse daquele ano não prestava mais. Aí nunca deram jeito, e ele disse que perdeu todinha essa mandioca, não teve como. Disse que fez umas duas farinhas [saco] pra comer e veio lá a conta. E foi muita gente assim, não foi assim?

Ao que responde Imá:

Todos foram assim. Sempre todos projetos de financiamento o embargo é isso aí. É o comércio. Todos. Qualquer projeto, qualquer financiamento, o final é isso aí porque o preço não é compatível com a conta que é feita. Não tem uma indústria, pra industrializar alguma coisa. O comércio local não consome tudo. Então se vende barato ele não é financiado e não paga a conta.

A produção, subtraída do empréstimo obtido, resulta no endividamento por problemas com a comercialização, em razão da incapacidade de absorção do comércio local e do estorvo com o escoamento, rebaixando-se os preços.

Avelino também personifica como o crédito mobiliza o trabalho entre os agricultores, ao narrar que os financiamentos crescem nos anos 1990 e que dos interessados é exigido que se reúnam em associações. Como beneficiária do projeto, à associação é reservada a função de mediação na concessão de empréstimos, cadastrando cada sócio como avalista do outro, em alternativa à titulação da terra e seus óbices correlatos, já levantados. Sobre os efeitos desse modelo de organização no trato dos empréstimos, pontua nosso entrevistado: 
Avelino: É que quando nós fizemos esse projeto, não tinha nada como segurança. A segurança era a própria associação. Aí, eu sei que acabou. Não tem projeto porque foi mal planejada desde o início. Primeiro, foi pra plantar coco. Aí quando nós já recebemos o dinheiro, foi liberado o recurso, aí nós compremo gado, um pouquinho de gado, pra investir num plantio. Aí mudaram pra café.

D.L.: Era pra ser pra gado e depois mudou pra café?

Avelino: Era pra ser pra coco. Aí mudou. Uns era pra citra, outros era pra coco; pra café. Aí na hora, desistiram porque não tinha muda, não tinha quem fizesse [...] Aí tinha os técnico da Emater, que vieram, escolheram a cultura, nunca fizeram... pra pegar sol. A maioria de nós [estava] na área de terra muito boa, que não precisava de adubo nenhum. Aí foi e se estragou tudo [...] quando a Emater veio liberar o café pra nós comprar dos japonês. Quando essas mudas vieram de ficar no ponto, foi no fim do inverno. Por isso que eu digo, que já começou errado, botar a muda num lugar desse. Mês de junho. Outros plantaram em julho. No verão! Plantaram ali, dez dias depois tava seco. Aí vai, se faz uma emenda do projeto pra comprar mais muda, no outro ano, pra plantar no começo do inverno.

Agora, a adversidade é relativa à má gestão do fornecimento das culturas pela assistência técnica e à condição climática e de período de plantio inconvenientes. Acrescemos que cada associado acessava apenas pequena parte do financiamento em dinheiro. Todo o restante era diretamente revertido em mudas, maquinário e insumos, inclusive com prescrição de onde os materiais deveriam ser retirados - no excerto, os japoneses forneciam o café ${ }^{110}$. Ceará conta como outro amigo se sentiu prejudicado por não ter direito de escolher que res obter:

Aí quando foi no dia seguinte, eu passei lá e ele me contando: "rapaz, eu
fiquei desanimado, que fiz esse financiamento, e quando acabar, na hora eu
não pude ver o que que eu queria. Não, foi os outro que me entregaram esse e
esse negócio". Ele disse: "não, os bicho que eu pensei que comprasse, uns
bicho bonito, é. Mas aí já foi financiado e repassado os bicho pro Adelino

\footnotetext{
${ }^{110}$ As mudas eram fornecidas pelo "finado" Seu Kishi, pai de Itajury (que nos apresentara o Limão), que para tanto mantinha uma fundação. Hoje, Itajury é presidente da Fundação Horto Florestal, que segundo o próprio, está falida: a entidade é beneficiária de um edital do Incra para prestação de serviços de extensão rural, mas não tem recebido os recursos que deveriam ser repassados. Digamos ainda que os técnicos da Emater e da Ceplac, os órgãos responsáveis por elaborar e acompanhar os projetos, são geralmente culpados pelo banco e pelos agricultores por orientarem insuficiente ou ineficazmente. Aliás, há uma cadeia de atribuição de culpa sobre os agentes envolvidos na disposição do crédito: o técnico, o banco, o "governo" em abstrato e, principalmente, o lavrador.
} 
entregar”. Aí eu disse: “É mesmo seu Gonzaguinha?”. "Se é. Quer ver? Você venha aqui e eu vou the mostrar uns bicho véio, assim, assanhado", aqueles bichinho véio peludo, feio. "Mas seu Rosário, foi esses bicho aqui?". "Foi esses bicho aí que me entregaram. Agora você vê aqui o custo". Eu fui lá ver o custo, o preço... ói, por isso que não me envolvo. Porque se fosse no meu caso, eu ia dizer "não, eu não quero, eu não quero esses bichinho. Eu é que vou comprar. Vou é escolher qual é o tipo que eu quero".

Quando é possível a liberdade de escolha, contudo, é aquela das opções ofertadas no mercado, não esqueçamos; o que está fora da escolha parece, para o beneficiário do crédito, "custo", expressão que convém caso pensemos na ausência de retorno de investimentos como prejuízo.

Todavia, o impacto mais cabal e nada surpreendente é a própria profusão do mercado fundiário e de seus desenlaces concatenados: os lavradores endividados passam adiante seus terrenos antes de morrerem ou para migrarem. Um mesmo lote, em uma década, está nas mãos do quarto dono, que paga as parcelas em nome dos antigos titulares do empréstimo e assim forma uma extensa pastagem, como diz Avelino:

Morreram bem uns quatro. E outros venderam e foram embora, pra Macapá, pra Roraima, só que venderam com a dívida. O cara que comprou, pagou [...] Agora, esses lá, o Bombonzão não sabia se eles moravam lá. Porque foi o seguinte: o do finado Roldão, o do Seu Edson, eles venderam pro Waldemar, Waldemar vendeu pra João Tomé, João Tomé já vendeu pro Bombonzão. Bombonzão era da cidade, mas não conhecia nada ainda. Aí nem sabe que esses terreno foi do pessoal da associação.

D.L.: Quanto tempo faz isso? Dez anos?

Avelino: É. Esse quarto dono comprou uma área assim, mais ou menos uns vinte terreno. Mais de vinte. Comprou os desses que eram sócios... a área dele é muito grande [...] Compraram tudo e venderam tudo pro Bombonzão. Bombonzão nem sabe se terreno que comprou se tinha gente dentro. Ele queria pro gado. Ele tem umas duas mil res lá, ou mais. Ele quebrou tudinho com trator, só terra boa. Transformou tudo em pasto. Mas os cara não fizeram nada: plantaram café, mas não prestou. Aí abandonou todo mundo. Esse primeiro fazia o roçado, plantava, tirava, e deixava pra lá.

Na associação do Limão (ACEPRDIL), criada em 1998, de 45 associados, apenas 26 obtém os benefícios, e nenhum quita a dívida com a própria produção. Quando o fazem é porque acessam dinheiro o suficiente por outros meios; por exemplo, vendendo parte de seu rebanho ou usando dos ganhos com algum comércio que possuem. Uma vez que o município 
é declarado inadimplente, vetando-se novos projetos, o Basa ocasionalmente organiza mutirões de renegociação das dívidas. No último deles, no segundo semestre de 2017, até $85 \%$ do montante emprestado originalmente poderia ser, por assim dizer, liquidado. Trata-se de modalidades de financiamento circunscritas a uma época, notadamente as modalidades previstas pelo BB nos anos 1980 e pelo FNO-especial no decênio seguinte. Outros empréstimos, sem excluir incontornável endividamento, são saldados com maior recorrência, com destaque para o microcrédito do Pronaf. Mais importante do que isso, no entanto, é salientar que há algo que subjaz a capacidade ou não de pagamento. A avaliação dessas políticas como desastrosas, tal como a proposição de novos modelos de gestão, têm por base critérios de eficiência que negligenciam como o crédito reproduz a ingerência estatal como momento do desenvolvimento capitalista.

Conforme temos discutido, o crédito consiste na operação do Estado para assegurar a mobilidade do trabalho (Gaudemar, 1977), no sentido de reproduzir o dinheiro como forma da mediação entre os agentes da produção. Junto a aposentadorias, Bolsa Família e outros programas de assistência, o dinheiro ofertado permite aos lavradores acessar um leque mais amplo de bens de consumo e reinvestir na produção, inclusive na contratação mais recorrente de diaristas ${ }^{111}$. Mas se a mobilização via de regra resulta no endividamento, quer dizer, em primeiro lugar, que o Estado pode arcar com altos índices de inadimplência de seus cidadãos e não falir. Em segundo lugar, que o capital pode se reproduzir baseado apenas na promessa de sua remuneração. E quando tais percursos se refletem em medidas estatais de manejo da população e de recursos na fronteira, os contornos são particularmente críticos (cf. cap. 4.4).

De qualquer forma, dever, posta a reprodução de capital autonomizada da imposição do trabalho, não requisita violência da mesma maneira que em outros contextos. Em uma situação de fronteira "aberta", o débito poderia motivar sanções para seus detentores, algumas delas de rigor explicitamente coercitivo, como esforço de reposição da dinâmica regional (Oliveira, 2008). Por sua vez, com a aparência de autonomia entre mercado e violência estatal, não quitar seu passivo, deixando o "nome sujo", interdita o acesso a uma mesma linha de crédito e a bens de consumo que exigem financiamento. Pronunciemos que por tal motivo Seu Avelino relata ter sido impedido de comprar um terreno em Teresina. Entretanto, para voltarmos à questão da cidade pequena, comprar onde todos se conhecem, no limite, faz das instituições de proteção ao crédito letra morta; ao mesmo tempo que a dívida estimula a venda

\footnotetext{
${ }^{111}$ Miguel diz que prefere recrutar diaristas pagando-os por produção, pois crê que assim seus contratados trabalham mais. Um contratado poderia responder que, dessa maneira, também ganharia mais.
} 
e a concentração de terras. Tudo se passa como se o problema do défice se resumisse à capacidade estatal de salvaguarda de mercados autônomos?

Seja dito de passagem, era comum no "tempo da associação" um embuste, espalhado por nomes ligados à pecuária e aos quadros políticos locais, de que o crédito representava um "fundo perdido", sem carência de ressarcimento. O efeito mais nítido fora, novamente, a catalisação do mercado fundiário, de modo que, antes da cobrança do empréstimo pelo banco, os devedores amedrontados pelos pecuaristas vendiam seus terrenos. Importante dizer, porém, que é o mercado o que respalda esses arranjos políticos de benefício a um determinado grupo, e não o contrário, haja vista estes grupos personificarem um metabolismo social automático.

Em que sentido o crédito mobiliza força de trabalho implica na disposição de um capital do qual o lavrador não é proprietário, mas que lhe permite explorar sua força de trabalho e se reproduzir. No capítulo da divisão do lucro em juro e ganho empresarial, Marx (1. III t. I, 1988, cap. XXIII) analisa que o juro tem sua fonte na mais-valia que o capitalista funcionante, industrial ou comerciante, extrai da exploração do trabalho alheio. Em outros termos, o capital monetário emprestado pode ser investido no processo produtivo, e retorna acrescido de juros para o proprietário de capital. De acordo com a formulação, na consciência do prestamista dinheiro gera mais dinheiro, sem passar pelo processo de valorização. Para o capitalista produtivo, por seu turno, o lucro se divide entre o juro a ser pago e o excedente sobre o juro, fixado aprioristicamente, sendo tal diferença o que lhe aparece como ganho empresarial (ibid.: 265). Juro e ganho empresarial são, assim, autonomizados do lucro "como se originassem de duas fontes essencialmente diversas": "uma como mero fruto da propriedade do capital, a outra como fruto do mero funcionar com o capital" (ibid.: 266). Em oposição ao juro, a persona que embolsa o ganho empresarial se apresentaria àquele, já que independente da propriedade de capital, muito mais como trabalhador. Ao último é decretado um "salário de superintendência", na condição de gestor tanto do capital quanto da exploração do trabalho alheios (ibid:: 270-1).

Extrapolando a digressão com uma proposição de C. Vecina (2018: 213) - sobre o funcionamento do Pronaf em comunidades quilombolas do Vale do Ribeira -, o agricultor deve gerenciar, com o capital emprestado, sua força de trabalho e de sua família na terra sem ser remunerado por isso, e tampouco sendo plenamente trabalhador ou gestor. O técnico naturaliza a autonomização do capital, et pour cause culpa o agricultor endividado por não ter sido um "bom gestor". Nas palavras da autora:

Acreditamos, assim, que é aqui que reside tanto o ideário da promessa do Pronaf, como a justificativa para seu fracasso sob o olhar dos técnicos. Isto é, 
do ideário que o crédito, se aplicado de acordo com o projeto por eles elaborado, irá explorar produtivamente o trabalho do agricultor familiar; e de que o fracasso se dá, pois, o agricultor não soube ser um bom gestor. Imputa assim ao agricultor, tanto o papel do trabalhador, como do capitalista funcionante, constituindo aquele, em realidade, plenamente nenhum dos dois: pois, não só sua autoexploração não chega aos níveis de produtividade a qual os técnicos apregoam; como também, antes de ser um gestor de trabalho alheio, para que consiga pagar o crédito, é preciso que o agricultor mobilize gratuitamente a força de trabalho de sua própria família. A crença dos técnicos explicita assim a aparência de autonomia (ibid.: 213).

A autonomização entre terra, trabalho e capital na unidade familiar é naturalizada pelos sujeitos à medida que opera objetivamente. Em nossa exposição, a terra é mobilizada por sua venda e pelo investimento capitalista que endossa a concorrência, autonomizando-se do trabalho. A força de trabalho, mobilizada para prover a reprodução familiar e permutada pelo equivalente geral, também aparece autonomamente como fator de reprodução de relações de produção, mesmo que mantida a posse da terra. Igualmente, a mobilização do trabalho deve remunerar, ao menos na promessa, rendimentos em juros do capital. A rigor, o que queremos sugerir é que a autonomização expropria o lavrador de suas condições de produção, mas sem necessariamente privá-lo fisicamente do acesso a essas condições. Por outro lado, a ostentação de autonomia pode ser cotejada com certa aparência de continuidade, ou de nãoautonomização. A partir de agora, veremos como esta aparência se constitui para parte da teoria social e, depois, no plano empírico e para o planejamento.

\subsection{Novas políticas territoriais e a "estrutura produtiva camponesa" na fronteira}

Em Myriam de Oliveira (2002), as mudanças mais significativas em Monte Alegre e Alenquer, desde a década de 1990, são o "ritmo de exploração mais dinâmico da terra" e o fortalecimento de movimentos sociais no campo, com consequência nos fomentos à agricultura familiar pela distribuição de novas linhas de crédito por parte do Estado $^{112}$ (ibid.: 56-7). A autora explicita como a postura do governo conduz ao incremento no volume de

\footnotetext{
112 “Contudo, a importância desses movimentos sociais e das representações da Agricultura Familiar vão além, pois através deles, da pressão que exerceram sobre a sociedade civil e o poder público, ganhos políticos foram conseguidos [...] a partir de 90, foram incentivadas e redirecionadas algumas políticas agrícolas tendo como pano de fundo a valorização da agricultura familiar. Um exemplo foi a criação de novas linhas de crédito menos burocratizadas, em contraponto às inúmeras linhas de crédito acessíveis somente aos produtores mais capitalizados. Talvez esse tenha sido a principal conquista do período" (Oliveira, 2002: 57).
} 
recursos aplicados no setor agrícola nacional, sendo investidos na concessão de créditos, na construção de ramais rodoviários e na assistência à atividade pesqueira (ibid:: 58). A diversificação do crédito rural favorece o acesso ao dinheiro por parte da agricultura familiar (ibid.: 58), amiúde diversificando a produção com a introdução de espécies vegetais perenes, como o coco, a laranja e o café (ibid.: 59). Ao mesmo tempo, os métodos de cultivo exercidos resultariam no esgotamento do solo, ocasionando a substituição de antigas culturas por outras que exigem menor fertilidade (ibid.: 59). A seu ver, a queda de rendimento se deve, em grande parte, à reserva de parcelas crescentes do terreno para crescimento de pasto, sem recuperação da terra, bem como ao emprego ainda embrionário de insumos e maquinário agrícola (ibid:: 59-60).

De pronto, o esquema equacionado condiz com transformações recentes alusivas às técnicas de produção: de um lado, a propalação do crédito rural e a diversificação do cultivo; de outro, o esgotamento dos solos e o esforço de compensação pela queda de rendimento através do investimento na terra. Compreendemos que, nos dois polos, a relação de capital vai instigando os produtores a estratégias que devem melhor posicioná-los no mercado, no processo de produção de mercadorias agrícolas. As estratégias em conta são, aí, caudatárias de uma forma de reprodução que autonomiza terra, trabalho e capital instituindo no dinheiro o meio de produzir na terra e localizando na mercadoria a forma da mediação social.

Mais a frente no texto, fica evidente como o argumento de Myriam tem no horizonte uma avaliação da "sustentabilidade dos sistemas de produção" da área, econômica e ecológica, para balizar a intervenção estatal. Economicamente, esses sistemas seriam sustentáveis ao menos a ponto de manterem as famílias e impedirem a desaparição das técnicas "tradicionalmente" empregadas (ibid.: 131-2). O mesmo não seria válido para a "sustentabilidade ecológica", em função de alegada agressividade no ritmo de exploração do solo, fruto do "empobrecimento técnico" e da ausência de transmissão de conhecimento entre as gerações de produtores (ibid.: 133). Daí a autora defender a manutenção dos "sistemas de produção tradicionais", com "ações futuras de desenvolvimento" adequadas às condições locais (ibid:: 134). Havendo tal expectativa, a disseminação do crédito numa pretensa ampliação da produção é positivamente recebida:

No quadro geral da evolução da margem esquerda, na figura dos municípios de Monte Alegre e Alenquer, a tendência da região com a proliferação de políticas como a de créditos, por exemplo, é de se inserir cada vez mais numa situação de mercado. Em função disso o mercado local vem se organizando e 
se expandindo em termos de oferta de serviços e de maior movimentação de produtos na expectativa de crescimento (ibid.: 137).

A posição não seria estranha a uma teleologia na qual o acesso ao mercado é não só incontornável, como até desejável. O tecnocrata seria o agente que orienta a movimentação de mercadorias pelo crédito rural e, salvo engano, pelo treinamento técnico, para viabilizar o "sistema agrário" da área. Nesse caso, fica de fora da crítica a relação do crédito com a mobilização do trabalho (Gaudemar, 1977) que expropria relativamente, ou seja, que mantém o acesso do produtor a seus meios de produção.

Como a aplicação de capital na terra na forma de insumos, maquinário, contratação de força de trabalho, etc. confere ao proprietário uma renda diferencial a seu terreno fora tratado no começo do capítulo. Sobre o crédito, M. de Oliveira (ibid.: 59) sublinha a preponderância do Programa Nacional de Fomento à Agricultura Familiar (Pronaf) e da linha especial do Fundo Constitucional de Financiamento do Norte (FNO-Especial).

Letícia Tura (2000: 29), em obra que avalia os impactos do FNO no Pará, informa que os fundos constitucionais são previstos na Constituição de 1988, mediante reversão de 3\% dos impostos de renda e sobre produtos industrializados para "programas de financiamento de setores produtivos das regiões consideradas as menos favorecidas do país" - ao Norte, no caso, são destinados 0,6\% desse montante. Os recursos do programa são administrados pelo Banco da Amazônia (Basa) e supervisionados pela Sudam, de acordo com o Plano Plurianual para a Amazônia, trienal (ibid:: 30). Assim, o FNO pretende constituir "um instrumento alternativo de política econômica para os mini e pequenos produtores e empresários, privilegiando o uso de mão de obra e matéria-prima locais" (ibid.: 30). O custeio é voltado para "atividades produtivas de baixo impacto ambiental", de modo que o Basa busca uma política de empréstimo flexível, que conjuga crédito fácil a juros baixos e, se necessário, ajustada a agendas locais ${ }^{113}$.

As diretivas assinaladas marcam uma distinção de conduta se comparadas aos planos regionais em vigor até meados da década de 1980, que lançam incentivos fiscais na espera de instalar na Amazônia grandes grupos empresariais. Como aludido no capítulo anterior, uma noção de região é construída, segundo o mote do "atraso", como superfície de intervenção sobre a qual são canalizados “fatores de produção". O que passamos a observar com o FNO é,

\footnotetext{
$113<$ www.sudam.gov.br/incentivo-a-investimentos/fundo-constitucional-do-norte-fno>. Acesso em: 08 de dezembro de 2016.
} 
progressivamente, a gestão da pequena produção familiar de baixo impacto ambiental como conduta estatal afinada à escala local.

A propósito, é justamente daí que Francisco de A. Costa (2000) denota um percurso de políticas públicas e sua relação com a "dinâmica agrária regional”, pretendendo compreender, segundo critérios de eficiência, a aplicação do fundo por "camponeses". Para começar, o autor enumera três estruturas em torno das quais se organiza a produção rural: a "unidade de produção camponesa familiar ${ }^{114}$,, a fazenda e a grande empresa latifundiária (ibid:: 65). A partir dessa diferenciação é que o autor, após caracterizar cada estrutura, interpreta projetos de Estado na Amazônia. Assim, durante a ditadura, a empresa latifundiária ocupa a fronteira, a despeito e/ou por razão da persistência de processos de "expansão das populações camponesas" e formação de novas frentes de expansão (ibid.: 77-9). Nesse caso, o importante seria limitar a estrutura extensiva camponesa para tornar a fronteira locus do investimento intensivo de capital (ibid:: 80). Para Costa, as políticas públicas modernizaram o latifúndio ao privilegiarem a grande empresa, pois forneciam os instrumentos da pesquisa agropecuária e subsídios enquanto obscureciam o campesinato, para o qual não era reservado qualquer papel estratégico (ibid.: 80-7).

Segundo o autor, o enunciado do esgotamento fiscal do Estado na década de 1980 significa também o fracasso do modelo da grande empresa agropecuária (ibid:: 87-9). Em compensação, o reordenamento da "base produtiva camponesa" se revelaria "em tendências surpreendentes" de crescimento, com a expansão do cultivo permanente e da criação e a retração da lavoura temporária (ibid.: 89-90). Por isso, as políticas deveriam ter nova ênfase: em vez de voltadas para empresas de fora da "região", se dirigiriam para áreas de colonização antiga, com maior gama de atividades contempladas (ibid.: 92). A redemocratização representaria relevantes modificações, notadamente a nova Constituição (que decreta o FNO), a publicação de dados sobre a produção agropecuária, a introjeção da questão ambiental na Amazônia, o crescimento do sindicalismo rural e a fundação do Programa de Produção de Alimento (ibid.: 94-7), que libera financiamentos para projetos familiares e tem efeitos considerados positivos, tanto para a dita produção camponesa quanto no registro do retorno dos investimentos (ibid.: 96).

Este parecer nos leva a considerar um projeto desenvolvimentista advogado pelo autor, que se desloca da grande empresa para o campesinato e tem semelhanças com a visão de $\mathrm{M}$.

\footnotetext{
${ }^{114}$ A concepção de campesinato é de matriz chayanovista, na qual, na leitura de Costa (2000: 65), a família é uma empresa simultaneamente unidade de produção e de consumo, assim definidora das necessidades reprodutivas que determinam a intensidade do trabalho e o ritmo de apropriação de terras na fronteira.
} 
de Oliveira (2002) quanto à positivação do crédito rural. Longe de depreciar as estratégias de reprodução dos assim chamados camponeses, problematizamos que premissas norteiam cada obra aqui apresentada como uma crítica do moderno - enquanto sociabilidade mediada pela mercadoria - que inclusive eu, indivíduo pesquisador, personifico.

O autor prossegue apontando que, na década de 1990, os movimentos sociais se fortalecem, tendo com o Grito da Terra - mobilizações anuais promovidas pelos sindicatos rurais de todo o Pará - sua maior expressão. Simultaneamente, o FNO vinha se instituindo com critérios "estritamente regionais" e "flexibilidade" para atender demandas locais (ibid.: 97-8). Na confluência entre os dois fatores, o Fundo reuniria atributos como: ajustamento da ênfase de atuação por discussão com organizações locais e segundo recomendações técnicas; mediação de personalidade jurídica coletiva para o crédito (associações), inclusive como substituto das garantias reais; imposição das prescrições técnicas por transferência do crédito na forma de insumos e negociação anual das condições de empréstimo (ibid.: 101). Seriam traços da "nova institucionalidade" das políticas agrícolas na Amazônia, que poderiam ser vistos enquanto deformação da proposta camponesa ou como avanço nas velhas regras do crédito agropecuário, mas nunca como definição unilateral de intervenção (ibid.: 101).

Só que, por assim dizer, à multilateralidade na correlação de forças que se exprime no FNO (e não só), subjaz o foco na flexibilização da política territorial, desde mudanças na garantia e no pagamento do empréstimo até o atendimento de demandas locais. Em sua Condição pós-moderna, Harvey (2012) pergunta se a acumulação flexível configura um novo regime de acumulação que sucede o fordismo ${ }^{115}$ ou se marca uma série de reparos transitórios no capitalismo do fim do século XX. O que interessa reter de seu diagnóstico de época é justamente que o termo "flexível" denota variações na organização e no controle do trabalho, mais do que nunca calcadas no mercado financeiro em expansão (ibid.: 177-81). Se um novo estágio de acumulação é contudo viável, é passível de discussão - que efetuaremos no encerramento do capítulo em torno de outro trabalho do autor. A respeito do planejamento,

\footnotetext{
${ }^{115}$ Por ele caracterizado, primeiramente, pela instituição da jornada de trabalho de cinco dólares por oito horas de trabalho em 1914 por Henry Ford (Harvey, 2012, cap. 8). Em alguns aspectos, trata-se de mera expansão de tendências já existentes, como a forma corporativa, a racionalização de tecnologia e a rigidez da divisão do trabalho especializado; a novidade, com efeito, estaria na produção de massa, que gera um consumo de massa e uma nova organização social, consolidados no pós-II Guerra. Aqui, o movimento operário sindical é cooptado mediante a negociação de salários com as empresas; o Estado se estabelece com políticas keynesianas, fiscais e monetárias, de investimento no setor público e de bem-estar social, funcionando como um regulador social do fordismo; e o capital corporativo se reorganiza para "garantir seguramente sua lucratividade" (ibid.: 113). O mercado global é ampliado com a diminuição do preço dos insumos, a internacionalização dos bancos e do turismo e a consolidação do poder geopolítico e econômico-bancário dos EUA. Podemos encarar esse período histórico segundo uma ampliação da exploração de trabalho consumido na reprodução de mais-valia, mas que tem seu limite histórico, a ser retomado como debate na última seção.
} 
desviamos o argumento de Harvey (2012, cap. 4) do projeto urbano para o território nacional: aqui, a concentração em planos de larga escala vai cedendo lugar a um conceito fragmentado de tecido territorial (ibid.: 69).

A política de crédito disponibilizada implica uma nova concepção do planejamento que fica, então, marcada pelo flexível e fragmentário. Tal agenda, que na visão de Costa (2000) é de certa maneira voltada para as demandas camponesas, pode igualmente nos levar à questão de que conceito de campesinato é esposado pelo autor. Sem largar uma teorização da regulação produtiva e de consumo de base familiar, o economista preconizaria, anos depois:

É função do Estado, na Amazônia - e certamente um macrodesafio do poder federal na Amazônia -, atuar no sentido de anular o hiato de tempo existente entre formas modernas e sustentáveis de uso dos recursos naturais da região e as necessidades cotidianas de suas populações (Costa, 2007: 130).

A passagem é do capítulo A questão agrária na Amazônia e os desafios estratégicos de um novo desenvolvimento, parte de um livro que reúne os resultados das pesquisas do programa Experimento de Grande Escala da Biosfera-Atmosfera da Amazônia ${ }^{116}$ (LBA). Nela, consideramos patente certo anseio por modernização, assimilado como intervenção do Estado, no senso de garantir o uso sustentável de recursos e se adequar às necessidades de populações locais. Necessidades classificadas numa escala temporal que, nada estranhamente, remeteria ao cotidiano dos grupos referidos a condição de "atraso" a ser suplantado. Apesar disso, o autor argumenta mais adiante, com emprego de coeficientes microeconômicos, como a unidade camponesa é mais produtiva que a fazenda e a empresa latifundiária (ibid.: 137). As estruturas camponesa e patronal - aglutinadora da fazenda e da empresa latifundiária representariam diferenças de uso e proporção de capital. A primeira estrutura se vincularia ao extrativismo e a uma agropecuária diversa, com emprego de capital humano na forma do trabalho familiar e da pequena produção (ibid.: 142). À ela associar-se-iam riscos ambientais relativamente baixos, já que a expansão da produção é regulada pela capacidade de trabalho da família (ibid:: 143). A última estrutura, por seu turno, se resumiria ao "extrativismo nocivo" de madeira e à utilização do solo enquanto suporte da agropecuária homogênea de latifúndio, com uso de trabalho assalariado pouco qualificado e em menor medida que a utilização de "kits mecânico-químicos" (ibid.: 142). As distinções expressar-se-iam, enfim,

\footnotetext{
${ }^{116}$ O LBA envolve institutos de pesquisa brasileiros e estrangeiros orientados para o entendimento de como que as mudanças no uso da terra e no clima afetam o ecossistema amazônico e sua sustentabilidade, e como tanto influencia no clima e na vida global. A concepção de ciência personificada pelos pesquisadores associados ao experimento fora tratada por Schor (2008).
} 
em antagonismos na disputa por recursos físicos, humanos e sociais - institucionais e infraestruturais (ibid.: 143).

Como conflito institucional, o FNO traduziria uma preferência pelo financiamento da pecuária do setor patronal de 1990 a 1995 e de 98 a 2000 (ibid.: 147). No intervalo entre as datas, quando maior atenção é dada à pequena agricultura, os bancos alegam, porém, que os novos clientes eram limitados em sua capacidade de absorção de crédito, apresentando potencial de risco além do previsto. Além disso, desenvolve-se uma defesa "sustentável" da pecuária, voltada à reforma de pastagens para evitar o desmatamento e ao investimento em animais de alto rendimento (ibid.: 148). Por conseguinte, a prioridade é transferida para as fazendas comandadas pelas classes dominantes locais, com a burocracia "se apropriando [da] pauta de desenvolvimento sustentável camponesa" (ibid.: 148). Da parte dos camponeses, afirma Costa, não seria difícil lamentar o oportunismo do Basa, ao que o autor rebate arguindo a "capacidade de mudança e desenvolvimento" da produção familiar (ibid.: 151). O campesinato teria "uma inclinação à montagem de sistemas produtivos baseados em diversidade", o que seria "uma qualidade quando se pretende uma agricultura com máxima esperança de sustentabilidade" (ibid.: 151). O interlocutor exige uma "nova institucionalidade federal na Amazônia", propondo, para concluir, seis estratégias de intervenção para elevar a “integração competitiva regional” (ibid.: 155-63).

Assim, se antes o autor reclama por modernização, incluso nos novos parâmetros de flexibilização transferidos para o trabalho camponês, agora exprime esse desejo na clara apresentação de um projeto de desenvolvimento sustentável que contemple o campesinato. Vemos daí que a categoria metodizada se aproxima daquela assumida por Martins (1975) e por A. U. de Oliveira (1991), na medida em que o camponês tem o trabalho familiar como pressuposto de sua unidade produtiva. Mas também se distancia dessas perspectivas, ao passo que esse camponês deve sustentar, via financiamento, a produção agrícola nacional. O período também é outro: não se trata, na teoria criticada, da "desmarginalização do campesinato" como válvula da acumulação primitiva nacional, como em Velho (1979). A conversão dos créditos do FNO para estes agentes implicaria a melhoria de um sistema que já é, aqui, mensurado como mais produtivo e diverso, num cenário diverso ao da depreciação ecológica de M. de Oliveira (2002). Em poucas palavras, o desenvolvimento reivindicado se integra ao nacional a partir da competição inter-regional, mas de uma maneira alternativa à alocação de fatores de produção vigente até meados dos anos 1980. Agora, a tônica é no ajuste à escala local e na centralidade do capital financeiro. 
Todavia, uma vez que empréstimos são disponibilizados, o resultado para o lavrador talvez seja aquele ligado a processos de expropriação: primeiro porque é preciso mobilizar trabalho mesmo de posse da terra para angariar dinheiro e se reproduzir. Segundo, em complemento, porque o dinheiro contraído demanda tornar seu beneficiário gestor de capital trabalhando e explorando trabalho não pago da família (Vecina, 2018: 213). Pensando nas teorias criticadas, a autonomização pretendida também defende a conservação duma pretensa independência camponesa, aliada à produtividade e sustentabilidade reputadas à reprodução familiar. Falando de outra maneira, as exposições se alicerçam na contradição entre autonomização e a simulação de não-autonomização das categorias do capital?

\subsection{Conflitos no PDS Serra Azul e o retorno à aparência de espontaneidade do lavrador}

Entre 2015 e 2016, circulou pela imprensa algumas notícias relativas ao Projeto de Desenvolvimento Sustentável (PDS) Serra Azul. São relatos de atentados contra moradores e casos de extração ilegal de madeira por indivíduos e empresas licitadas, respaldados por órgãos federais. Os produtos mais flagrantes dessas ações são a tentativa de assassinato de uma liderança local e a prisão do superintendente do Incra de Santarém.

Em maio de 2015, a Comissão Pastoral da Terra (CPT) de Santarém denunciou ${ }^{117}$ uma emboscada armada contra Luiz Paulo da Silva (Paulinho), ocorrida no início do mês anterior: a liderança é cercada por três pistoleiros e reage em legítima defesa, precisando então, em virtude de sua segurança, fugir do assentamento com a família. Acontece que, consoante ao relato, as ameaças ao agricultor já se estendiam desde a criação do PDS, em 2005, e se agravavam. A delação das irregularidades cometidas, sobretudo quanto à ação de madeireiros, culminou na conduta dos jagunços. Primeiro em outubro de 2014, quando a casa de Paulinho foi alvo de dezenas de tiros. Depois, chegamos à tentativa das "vias de fato" que motivam a nota aqui resumida. Muito disso, segundo a CPT, por "omissão e/ou conivência" das instituições locais, haja vista a oficialização das queixas. Por tal motivo, concluem por exigir a proteção de Paulinho, o atendimento das reivindicações dos moradores e a coibição das práticas dos grileiros e madeireiros.

Desse modo, Paulinho esteve refugiado por um período. Enquanto isso, já aberta uma denúncia junto ao Ministério Público, a Polícia Federal (PF) aciona a Operação Madeira Limpa. A operação tem início em 2014, mas as notícias se concentram nos resultados da ação

\footnotetext{
${ }^{117}<$ www.cptnacional.org.br/publicacoes/noticias/articulacao-cpt-s-da-amazonia/2566-cpt-santarem-divulga-n ota-sobre-atentado-contra-uma-lideranca-do-pds-serra-azul>. Publicado em: 7 de maio de 2015. Acesso em: 27 de janeiro de 2018.
} 
policial, na última semana de agosto de 2015. O site do G1 relata ${ }^{118}$, no dia 24 , a prisão de empresários do setor madeireiro e de funcionários públicos, entre eles o então superintendente local do Incra, Luiz Bacelar Guerreiro Jr. Consta, por depoimento da procuradoria da república, que Bacelar permitia a exploração ilegal da madeira situada em áreas de assentamento e nas unidades de conservação circundantes, também obstruindo a canalização de benefícios para os assentados. Segundo a delegacia local da PF, na matéria, o esquema funcionava através da ação conjunta de instituições, em que empresas embargadas eram liberadas pelas secretarias da fazenda ou meio ambiente, terras eram tituladas pelo Incra e fiscalizações pelo Ibama eram previamente informadas.

Para encerrar os relatos, na edição do Fantástico do dia 30 foram exibidas outras ações que envolviam madeireiras ${ }^{119}$. Empresas licitadas para o manejo de madeira retiravam recursos em áreas fora de sua incumbência legal, sendo esta "madeira fria" posteriormente "esquentada" em serrarias de Santarém; isto é, seriam emitidas notas fiscais que regulariam o procedimento de extração como um todo. Nos projetos de reforma agrária, por seu turno, o Incra estaria desassistindo os assentados com a intenção de facilitar a obra dos criminosos, o que levaria à coação daqueles moradores ao trabalho com as empresas e mesmo à venda de seus lotes. Estes tópicos foram reafirmados com a exibição de uma entrevista com Paulinho, que delata o descaso proposital do Incra e o fortalecimento de quem passava a desferir ameaças algo mais constantes contra as lideranças contestadoras, chegando à situação-limite em que tentaram assassiná-lo. Na época, Paulinho ainda não havia retornado ao PDS.

As narrativas introduzem casos de violência que caracterizam as relações com a terra numa área disputada. Fontes jornalísticas estão situadas num contexto, tal como a violência e a intromissão do Estado, componentes da territorialização do capital. Temos nelas a criação do PDS próximo a unidades de conservação, onde empresas licitadas exploram madeira ou o fazem ilegalmente, movendo artifícios de coerção à revelia das denúncias dos assentados. São mecanismos que, além de tudo, revelam o interesse pela usurpação de terras, reforçados no descaso deliberado do Incra, que tolhe dos lavradores direitos vinculados a seu assentamento, e mais, convindo e integrando os arranjos fraudulentos.

Convém descrever que o PDS Serra Azul é um assentamento de grandes dimensões, com mais de 78 mil hectares de extensão, delimitado a partir de um ramal que corta, sentido

\footnotetext{
$118<$ g1.globo.com/pa/santarem-regiao/noticia/2015/08/superintendente-do-incra-e-preso-na-operacao-madei ra-limpa.html>. Publicado em: 24 de agosto de 2015. Acesso em: 27 de janeiro de 2018. <g1.globo.com/pa/san tarem-regiao/noticia/2015/08/operacao-madeira-limpa-cumpre-mandados-de-prisao-em-santarem.html>. Publicado em: 24 de agosto de 2015. Acesso em: 27 de janeiro de 2018.

${ }^{119}<$ www.youtube.com/watch?v=0jz8zkSOSYY>. Acesso em: 27 de janeiro de 2018.
} 
norte, o Setor Seis da PA-254. Conquanto datado de 2005, o projeto tem a ordem de regularização fundiária inconclusa, em função dos conflitos pela propriedade da área. Ainda assim responde, hoje, pela maior parte da produção agrícola de Monte Alegre - sobretudo de banana, tomate, cacau e gêneros de lavoura branca. Ele é dividido em uma parcela de reserva legal, para a qual fora previsto um plano de manejo, e dois núcleos, cada qual com sua associação: Matona, a aproximadamente $110 \mathrm{~km}$ do perímetro urbano de Monte Alegre, e a comunidade de São Francisco, ou Serra Azul, distante cerca de $30 \mathrm{~km}$ da primeira localidade. A estrada principal é pirraçada e atravessada por poucas vicinais, onde estão dispostos os lotes e as residências, erguidas com madeira extraída do fundo dos terrenos. Encontramos em volta da sede da associação da Matona o comércio e pequenos galpões que funcionam como escola, enquanto em São Francisco a rua é lotada com a sede e o comércio, avizinhados de duas igrejas em construção, um campo de futebol e um galpão que abriga a escola para as crianças menores (figs. 9 e 10). Não muito distante, há uma oficina mecânica, e no ramal da Taboca um pequeno barraco funciona como posto de saúde. Inexiste iluminação pública, e as residências são abastecidas com placa solar, gerador ou bateria automotiva, transmitindo energia para televisor e (se o equipamento tiver potência o suficiente) geladeira. Caso contrário, alimentos são estocados em isopor com gelo.

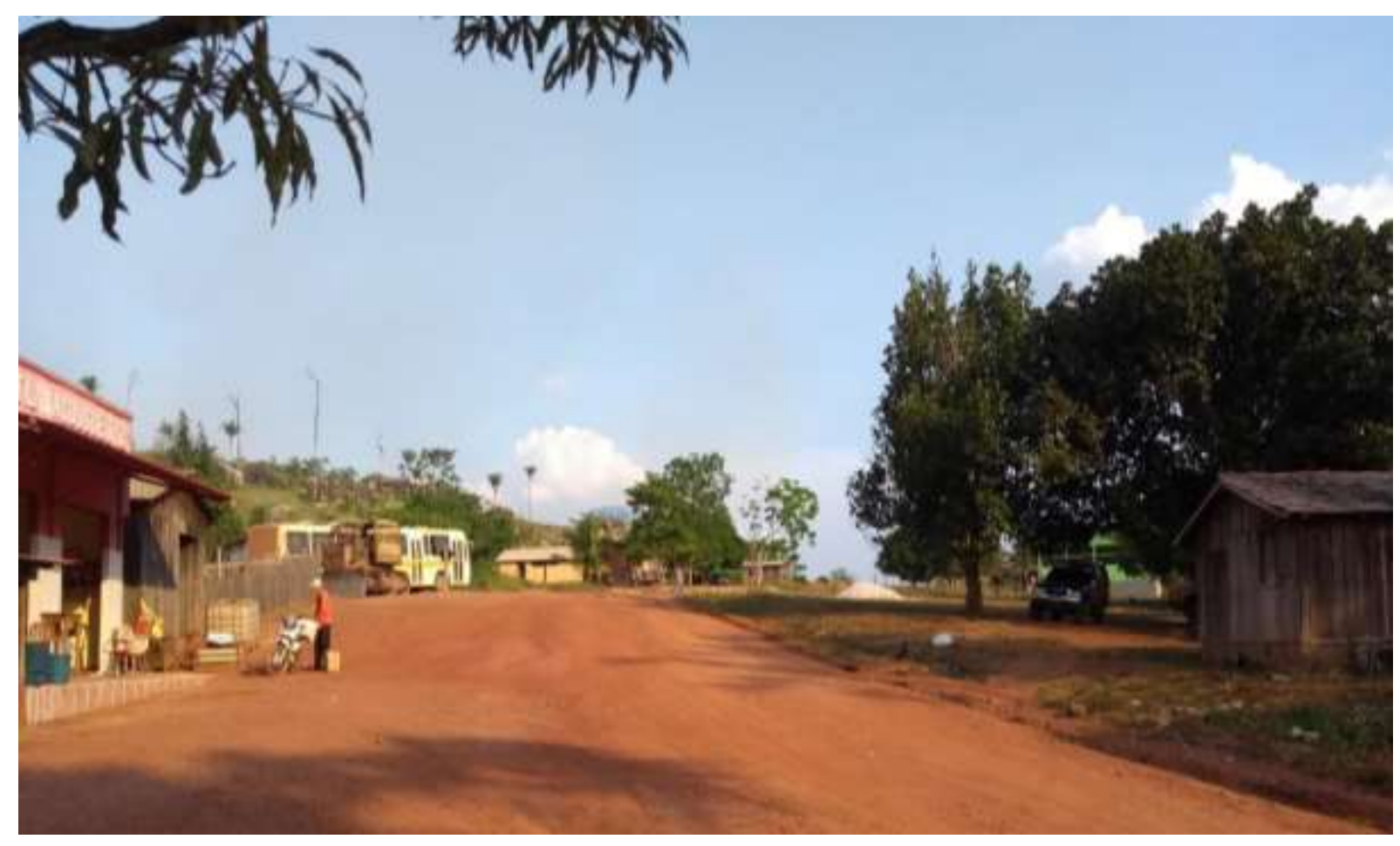

Fig. 9. O núcleo de Matona. Em primeiro plano, à esquerda, o comércio, onde o senhor de moto se prepara para fazer compras. Ao fundo, o ônibus escolar e o barracão que abriga a escola se superpõem a campos desmatados com fim à criação de gado. À direita, a sede da Associação dos Produtores da Matona Serra Azul (Promasa). 


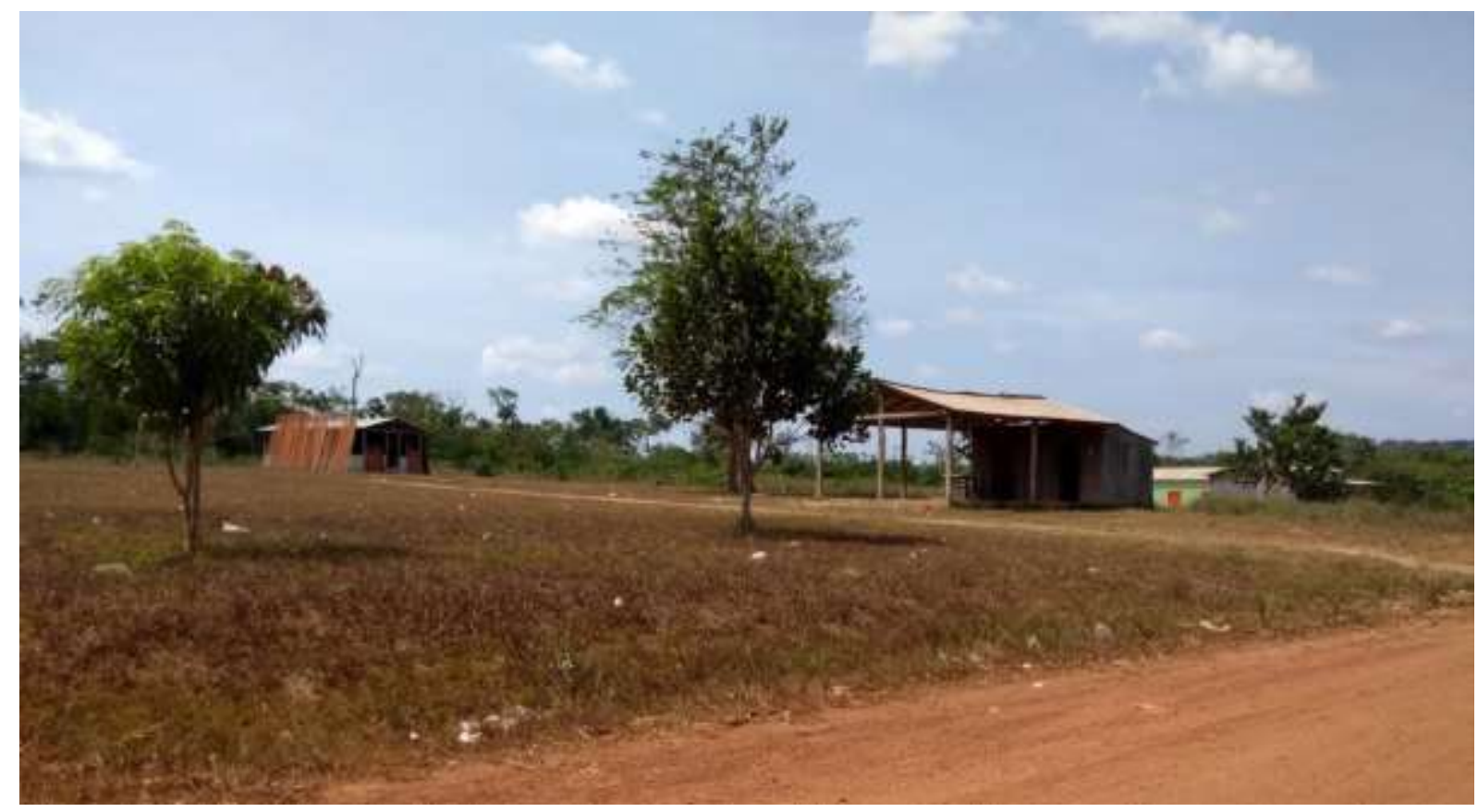

Fig. 10. A rua na comunidade São Francisco. À esquerda ao fundo está a sede da Associação dos Agricultores da Serra Azul (AASA). A casa em destaque é a antiga escola, enquanto ao fundo, de alvenaria, encontra-se a igreja católica. Do outro lado da estrada está o comércio e a igreja protestante.

Estivemos na comunidade em novembro de 2017 (dois anos após os fatídicos acontecimentos) devido à outra carona oferecida por Itajury. Foi quando tivemos oportunidade de conhecer Paulinho, ex-líder da Associação dos Agricultores da Serra Azul (AASA), e nos hospedarmos em sua casa por duas semanas. Na primeira entrevista que efetuamos com o lavrador, ele nos narra como o projeto é fundado, qual a relação entre as associações, com as áreas adjacentes e com madeireiras, além de opinar acerca do andamento da regulação da terra no interior do projeto.

Paulinho coloca que o debate sobre o PDS tem início em 2004, entre produtores que, por não possuírem terra, passam a organizar reuniões e a ocupação da sede do Incra para a reivindicação de um assentamento. Na época, a paragem em foco já estaria, como diz, "mais ou menos grilada" em demarcações de 2500 ha $^{120}$, efetuadas a mando de fazendeiros sulistas com voos sobre a floresta. Com tal obstáculo, dois anos transcorrem da abertura da portaria de criação do projeto, de $2005^{121}$, aos primeiros ensaios de ocupação do local pelos lavradores. A AASA também surge em 2007, reivindicando, primordialmente, a regularização dos lotes nos moldes de um PDS, enfrentando, mais tarde, um embargo ambiental da justiça federal, na expectativa de subordinar a área ao Programa Terra Legal e às suas diretrizes. A determinação

\footnotetext{
${ }^{120}$ Aliás, é essa a medida máxima aceita pela União como terra devoluta alienada.

${ }^{121}$ Publicado no Diário Oficial da União (21 de outubro de 2005: 104). Disponível em: <www.jusbrasil.com.br/di arios/836579/pg-104-secao-1-diario-oficial-da-uniao-dou-de-21-10-2005>. Acesso em: 16 de agosto de 2018.
} 
só é revogada com nova ocupação do prédio do Incra. A partir daí, e com a abertura da estrada principal entre 2008 e 2009, a chegada de famílias à comunidade é crescente.

A série de impedimentos com a qual os agricultores se deparam antes de qualquer medida que lhes possa garantir a estadia naquelas terras salta aos olhos. É destacável que o Estado atua tanto no sentido de assentar famílias em lotes quanto na negligência que fortalece ameaças da parte de latifundiários interessados na realização de seus objetivos, caso levado em conta os conflitos noticiados. E o esforço no decreto do Programa Terral Legal é um feito a parte, a saber, justificado a partir de supostas irregularidades no licenciamento ambiental ${ }^{122}$.

Diga-se de passagem, pois retornaremos ao problema em breve, o programa é criado pelo extinto Ministério do Desenvolvimento Agrário (MDA) em 2009 ${ }^{123}$, com a meta de acelerar a regularização de imóveis rurais de até 15 módulos fiscais - em Monte Alegre, o módulo corresponde a 75 ha -, prevendo, para tanto, o cumprimento de cinco fases de projeto: cadastramento das posses, georreferenciamento, vistoria, emissão de títulos e monitoramento pós-titulação (Brito e Barreto, 2010: 9). Mas o que levaria à criação do programa, em lugar de se prosseguir com a atribuição da tarefa de documentação, quando se trata de terras devolutas da União, ao Incra? O objetivo seria segmentar encargos em favor de uma nomeada eficácia técnica? De uma forma ou outra, a execução do Terra Legal nos limites da Serra Azul contraria o interesse de muitos lavradores, provavelmente em benefício de outro grupo (para dizermos o mínimo), com um respaldo de cunho ambiental. Respaldo que nos permite pinçar um apontamento no que respeita à constituição do Estado: como agente da modernização, ele próprio se autonomiza em diferentes instituições e formas de atuação, não necessariamente coerentes entre si mesmas. A expectativa do Estado uniforme e da regulação política colide com o amparo a latifundiários ou lavradores, ou com a omissão das reivindicações lavradoras, por exemplo. Dessa feita, tampouco o Estado consiste em mero instrumento de classe ${ }^{124}$.

\footnotetext{
${ }^{122}$ Encontramos uma notícia de 28 de agosto de 2007 acerca da interdição pela Justiça Federal do Pará de 99 assentamentos por irregularidades no processo de licenciamento ambiental. As famílias assentadas estariam impedidas de receber recursos públicos e de regularizarem suas parcelas. Para o juiz de Santarém, o licenciamento deveria ficar a cargo do Ibama - e não da Secretaria Estadual de Meio Ambiente - , assim como, para a Promotoria Pública, a regularização dos assentamentos atenderia aos interesses de madeireiras. Disponível em: <www1.folha.uol.com.br/fsp/brasil/fc2808200728.htm>. Acesso em: 30 de janeiro de 2018.

${ }^{123}$ Desde 2016, Secretaria Especial de Agricultura Familiar e do Desenvolvimento Agrário, vinculado ao Ministério da Casa Civil, passando o Terra Legal à Subsecretaria de Regularização Fundiária da Amazônia Legal, filiada à secretaria supracitada.

${ }^{124}$ Aqui seria viável rebater o senso comum do marxismo, resgatando o debate da "dominação sem sujeito" de Kurz (2010), presente em nosso primeiro capítulo (nota 20). Extrapolando aquelas apreciações, indicamos que interpretações do Estado veiculado à burguesia reduzem-se ao cálculo subjetivo do dominador e obnubilam a irracionalidade - pois tautológica e imanentemente crítica - da dominação abstrata, pressupondo uma instituição com interesses pré-definidos e uma classe capaz de agir em conjunto.
} 
Paulinho vem do Setor Nove, onde lavrava no terreno do pai, e se organiza com outros sem terra para a ocupação das situações que hoje integram o projeto, à revelia dos grileiros:

D.L.: Com o senhor mesmo, como foi que o senhor chegou aqui?

Paulinho: Nós era do Setor Nove e nós pleiteou essa área. O Incra criou o assentamento, né. E nós viemo pra cá e pleiteemo essa área.

D.L.: Era do seu pai o terreno?

Paulinho: Do Setor Nove era. E agora ficou com um irmão meu lá. Aí nós viemo pra cá e pleiteemo aqui. Fizemo um acordo, até lá no sindicato, em 2008. A gente tava criado o assentamento, mas não tinha brecha pra entrar, e a gente entrou aqui 5 de agosto de 2008. Nós entremo com 80 homem. Quando nós cheguemo aqui tava cheio de caboco aí também espalhado, né.

D.L.: Tinha gente já.

Paulinho: É, mas o contra, né. E aqui foi um confronto de gente aí nessa mata! Só que os cara amansaram. Eu lembro que tava bem ali, o Ciro [madeireiro] e dois caboco. Cada qual com uma pistola, entendeu. Aí a gente também não amansou pra eles, e ele foi embora. Aí se criou, né.

D.L.: Esse pessoal do Sul, eles saíram e foram pra onde?

Paulinho: Uma grande parte foi embora. Eles já tavam em Novo Progresso, Uruará, voltaram pro Sul de novo, né. Outra ficou aí pelo município, quebrado financeiramente, porque eles pleitearam o assentamento, perderam essa área aqui, correram mais pra frente ali na Flota... perdere também. Criaram a Flota Paru. Então eles ficaram arrebentado, né, se arrebentaram. Aí foram embora.

D.L.: Mas eles não resistiram?

Paulinho: Não. Teve uma resistência, houve uma resistência e até hoje ainda há. Tem duas pessoas aqui, que a gente não conhece eles, praticamente. Eles veve aqui, uns $5 \mathrm{~km}$ daqui, e são meio violento até. Tá com uns quatro meses, cinco meses... eles tem pique, usam pessoa no pique, de resistência. Corredor de pique que chama, né. O rapaz foi atravessar o pique dele, e quem atravessa o pique dele pra lá é bala, né? Daí o rapaz tentou atravessar ${ }^{125} \ldots$

\footnotetext{
${ }^{125} \mathrm{O}$ atentado é recente, e ganha mais notoriedade com a divulgação de uma nota por parte da Pastoral da Terra. A CPT relata que duas famílias foram vítimas de uma emboscada armada por pistoleiros, sendo um dos indivíduos ferido no braço e no tórax. O jagunço suspeito é conhecido nas cercanias como Paulista Preto, contra quem já fora registrado diversas denúncias. Conclui-se afirmando que os grileiros derrubam a floresta para a formação de pastos, bem como para a descaracterização do PDS, visando à regularização das áreas griladas. Disponível em: <www.cptnacional.org.br/index.php/publicacoes-2/destaque/3691-nota-publica-famili as-do-pds-serra-azul-pa-sofrem-nova-tentativa-de-homicidio>. Acesso em: 30 de janeiro de 2018. Em adendo à nota, sabemos que o grileiro em questão é chamado de Baiano, com terras sobre a área de reserva legal do PDS. Recentemente, a gerência do manejo foi transmitida, via licitação, para o Instituto do Homem e Meio
} 
Podemos dizer que o PDS surge como alternativa na ocupação da terra para lavradores que não detinham seus próprios meios de produção, sendo resultado do esgotamento gradual da expansão da fronteira. Trata-se do esboço de uma derradeira oportunidade de posseamento da terra, et pour cause tanto o projeto quanto o corredor ecológico são concebidos para barrar a fronteira madeireira e pecuária? De qualquer forma, os grileiros não evadem de pronto. Ao contrário, eles podem inclusive conjuminar com personas do Estado para ficarem, como acontece quando "esquentam" madeira. O percurso apresentado é de aguçamento de conflitos até o atentado contra Paulinho e a prisão do superintendente do Incra, restando na área os que se empregam da pistolagem para salvaguardar o que julgam ser seus domínios.

Uma vez situados, os lavradores se organizam para dividir os lotes e fundar a rua. Eles provêm de diversas partes do município, e trabalham em conjunto na abertura dos terrenos e na formação do primeiro roçado.

Paulinho: Eu vim do Setor Nove. Mas teve gente da região da Canp, Cauçu, Santa Helena, PA, Limão, Novo Brasil, de todo o município, Maicuru pra ali, veio pra aqui. Todo o município.

D.L.: Principalmente porque tavam se organizando antes, né?

Paulinho: Era. Só assim mesmo. A gente combinava e botava no rádio de que vinha, ou então pegava a moto e visitava.

D.L.: Mas como era pra abrir terreno?

Paulinho: Nós abria em conjunto. Até porque, quando nós viemo pra cá, o confronto era mais pesado. Aí nós dividimo, dividi... nós era oitenta homem. Dividimo oito equipe de dez. Aí oito trabalhava e dois pastorava aqui. Todo dia fazia um roçado. Dois hectare. Todo dia. Mas tinha dois dentro do mato: “oh, se vim, pode meter chumbo, pode matar essa peste!" Então, pra nós fazer isso aqui... muito pouca gente sabe disso, né. Mas foi só mais ou menos essa vez que a gente se organizou de grupo. Aí cada qual assumiu o seu papel aí.

D.L.: Demorou bastante isso aí?

Paulinho: Não. Nós fiquemo 45 dia, pra fazer esse serviço. Aí no fim já ficou três, quatro, derrubando, e os outro concluindo o roçado dos outro.

D.L.: Aí pra colheita ainda acontece esse tipo de mutirão?

Paulinho: Não. Aí é individual mesmo. Cada qual paga o seu.

Nesse sentido, a composição do PDS é similar à dinâmica de outrora na fundação de comunidades, com o arranjo de empreitas coletivas, sendo a singularidade do caso a tensão 
diante da chegada de pistoleiros e a urgência de se prevenir. Por sua vez, esboçam-se desigualdades na função dos aparatos técnicos na execução dos serviços, a saber, na comunicação por rádio, nos deslocamentos de motocicleta - também porque não se percorre grandes distâncias - e na aceleração do puxirum com o uso de motosserra.

Segundo alguns depoimentos, no entanto, o movimento de expansão da posse antecede o estabelecimento da grilagem e a estratégia organizada de conquista da terra pelos lavradores do PDS. É o caso de produtores expropriados atravessando do Setor Seis para "terras livres" rumo ao norte, que são contrários ao modelo regulatório de PDS. Na comunidade de Matona, Lúcio e seu filho, Reinaldo, reivindicam para si o ato de terem sido os primeiros a efetuarem tal travessia, em $1999^{126}$. O "achamento" destes confins é narrado por Lúcio a partir do acaso de caçadores que se perderam e divulgaram para os colegas a existência de "terra muito boa":

Era caçador, que vinha caçando, se perdeu e achou essa terra aqui. Aí: "rapaz, achei umas terra muito boa lá dentro". Aí nem fui eu, foi um irmão meu que veio. Aí, "rapaz, eu tenho uma terra ali junto do meu sogro, se tu quiser eu te dou. Meu sogro disse que não vai pra lá" [e eu disse] "bora lá ver". Isso foi em 98. Aí em 98 eu vim olhar e disse: "rapaz, onde boto roçado aqui?" Ah, o pessoal disse que não vinha. Eu disse: "venho". Vim, botei um roçado e não queimou. Era mato, escuro, fazia um frio, frio. Aí eu fiz e o roçado não queimou. Aí deixei encapoeirar e broquei de novo. Aí queimou. Aí não tinha brocado assim. Aí botei o barraquinho ali na frente.

Malgrado a constituição de um roçado numa terra pretensamente inexplorada, envolvendo a derrubada da floresta, a queimada, a brocada sobre a capoeira, a construção da casa, etc., a parcela já parece divisada por alguém que a doa para Lúcio. Com o andamento do relato, é reforçada a noção de que os primeiros esboços de povoação transcorrem da demarcação de lotes acessados através da doação sobre a posse. Assim, a comunidade surge e se desenvolve pela multiplicação e dilatação de terras apossadas.

D.L.: Quem ficou sabendo das terras era quem tava no Setor Seis?

Lúcio: Era. Que sabia e que vinha. Vinha chegando. Tem muito que chegava: "arruma terra pra mim"; "rapaz, tem terra pra ali?"; “Tem”. Aí vinha, tava

\footnotetext{
${ }^{126}$ Assim considerando, a ocupação não é tão antiga, embora já se soubesse daquele local. Em seu livro de memórias, o montealegrense Cícero N. de Almeida (1979) reproduz um fragmento de Charles Frederik Hartt no qual o naturalista, ao publicar em 1874 seus estudos sobre a geologia do Baixo Amazonas, relata a existência de uma "Serra Azul" num horizonte distante, a leste da vila. Já sobre sua chegada em 1999, diz Lúcio: "Primeiro que botou roça aqui fui eu. Bem junto aí do acostadinho tem gente que fala que entrou em 2002, 2003. Eu não. O primeiro roçado que botei aqui foi em 99. Entrei em 98 [...] eu e aqui com meu filho. Aí em 2003, Paraguai já botou ali, já veio morar. Eu entrei também pra morar com esse aqui. Eu sou do morador mais velho daqui".
} 
desocupado e eles iam entrando, sabe? Aí eles vinham, tiravam terra e iam entrando, iam entrando. Aí depois que nós tava aqui, que tava com o roçado brocado, foi que o Incra veio até aí [...] Aí que o Incra marcou o PDS.

O ocorrido é semelhante à empresa de quem primeiro "assitua" um local antes inabitado e se firma como "dono do centro", com certa autoridade na permissão ou recusa da instalação de novos moradores - como observamos, guardadas suas singularidades, com Wilson e Paulino e apoiados em Musumeci (1988). O juízo é de autonomia, sendo o óbice, para os entrevistados, a intromissão tardia do Incra na circunscrição do PDS. Ao mesmo tempo, não se deve ignorar que relações se colocavam entre os mesmos produtores que os impeliam a recorrer a novas "terras libertas". Reinaldo mesmo, "trabalhava em terra dos outro" como vaqueiro:

Eles davam lá pra gente trabalhar. Criador, né. Pagava nós pra botar o capim pra eles, né. Botava a roça e plantava o capim pra eles.

D.L.: A roça era de vocês mesmo?

Reinaldo: Era.

D.L.: Ele cobrava alguma coisa pelo que vocês vendiam?

Reinaldo: Não. Se ele me chamava pra fazer algum trabalho, eles pagavam.

Reinaldo é pago em diária para cuidar do rebanho e cultivar o pasto, e recompensado a parte no caso de contratação de serviços extras. Prima facie, ele mantém relativa independência cultivando seu roçado, sem restituir renda em trabalho, produto ou dinheiro para o proprietário fundiário. O que não aparece na relação é como o patrão subtrai os custos de manutenção de seu gado extraindo sobretrabalho do agregado na forma do vencimento em diárias. Ter permissão de lavrar e ainda ser pago, no entanto, não contrabalança a chance de se prosseguir com o posseamento de "terras livres".

Nessa medida, a mobilização de terra, trabalho e capital na área pode se processar conservando na reprodução dos lavradores elementos de continuidade, ou, por assim dizer, de aparência de não autonomização com dinâmicas regionais (Oliveira, 2008). Concretamente, certas condições de reprodução perduram, obnubilando modificações da totalidade.

Muitos dos lavradores com quem convivemos cultivam lavoura branca basicamente para consumo da família e da pequena criação, além de hortaliças e "fruteiras", com destaque para a bananeira e o cacaueiro. As culturas permanentes são voltadas para a venda, realizada no comércio local ou embarcada em "carros de horário", leia-se caminhões ou antigos ônibus que seguem diariamente para a cidade, a custo de dez reais por saca - ou 30 reais por pessoa. $\mathrm{Na}$ localidade, o lavrador pode abrir uma conta com o comerciante e ter o débito descontado 
com sua produção, sendo as transações calculadas em termos monetários. Na cidade, a produção é repassada a dinheiro para o atravessador ou comercializada diretamente na feira do sindicato dos trabalhadores rurais do município, às terças e sextas-feiras. Os proventos são poupados ou dispensados na compra de bens não produzidos pelas famílias, como sal, enxada, terçado, gasolina e gelo, ou bens que, para algumas delas, com dizem, não compensa fabricar, como sabão, óleo e até arroz ${ }^{127}$.

No interior da Serra Azul também vigora um mercado fundiário, em pequena proporção. O PDS é um modelo de assentamento que não prevê a titulação de propriedade, mas certificados de uso que não permitem a venda, nada obstante ocorrida enquanto não é emitida a documentação. Comentam sobre isso dois moradores:

Jorge: Tem muito nego aí que passa a terra pro outro.

Parazinho: Ainda hoje, o Incra teve com nós aí. Uma coisa lamentável, porque ainda que o Incra, por mais devagar que teje, né, mas se nós tivesse fazendo a coisa bem legal, todos eu digo, né Jorge, ficava mais fácil de se organizar, mas o Incra chega hoje aqui e visita, amanhã o Incra volta no mesmo lugar pra visita e [tem] outro dono.

Jorge: E também, como é também, aqui tem lote que tá com a família morando, tem lote que o cara não tá morando, então eles querem organizar a situação; ou o cara vem pra dentro trabalhar. Se ele não tá aqui dentro, é porque ele não precisa da terra, né. Enquanto tem muitos aqui dentro que tão aqui, às vezes agregado com a família, né. Tá o cara, tá o filho, com a família, morando no mesmo terreno, aí não tem a terra, né, mora com os pais. Então esses cara que não tão na terra, não; eles tem outras opções por fora, né. Aí, a terra é do governo, aí o Incra vai e vê o que fazer da situação, né: ou passa pra quem tá aqui dentro e precisa trabalhar, ou quem tá lá fora vai ter que vim.

De certo modo, a venda de terrenos retarda o processo de regularização do projeto, o que não deixa de ser uma componente de conflitos, levantando o dever de inspeção do Incra. Enquanto estávamos em campo, funcionários do instituto legalizavam os assentados que integravam a Relação de Beneficiários (RB) do PDS e notificavam quem não estivesse naquela situação. A intenção era distribuir os lotes para quem possuísse "perfil de agricultor", segundo o qual o indivíduo deveria estar e necessitar da terra, para, então, se atingir a meta de erradicar as transações.

\footnotetext{
${ }^{127}$ Nobó diz: "E o arroz, tá compensando mais comprar no quilo lá na cidade que a gente plantar, porque, só pra levar, é dez reais, e trazer mais dez reais".
} 


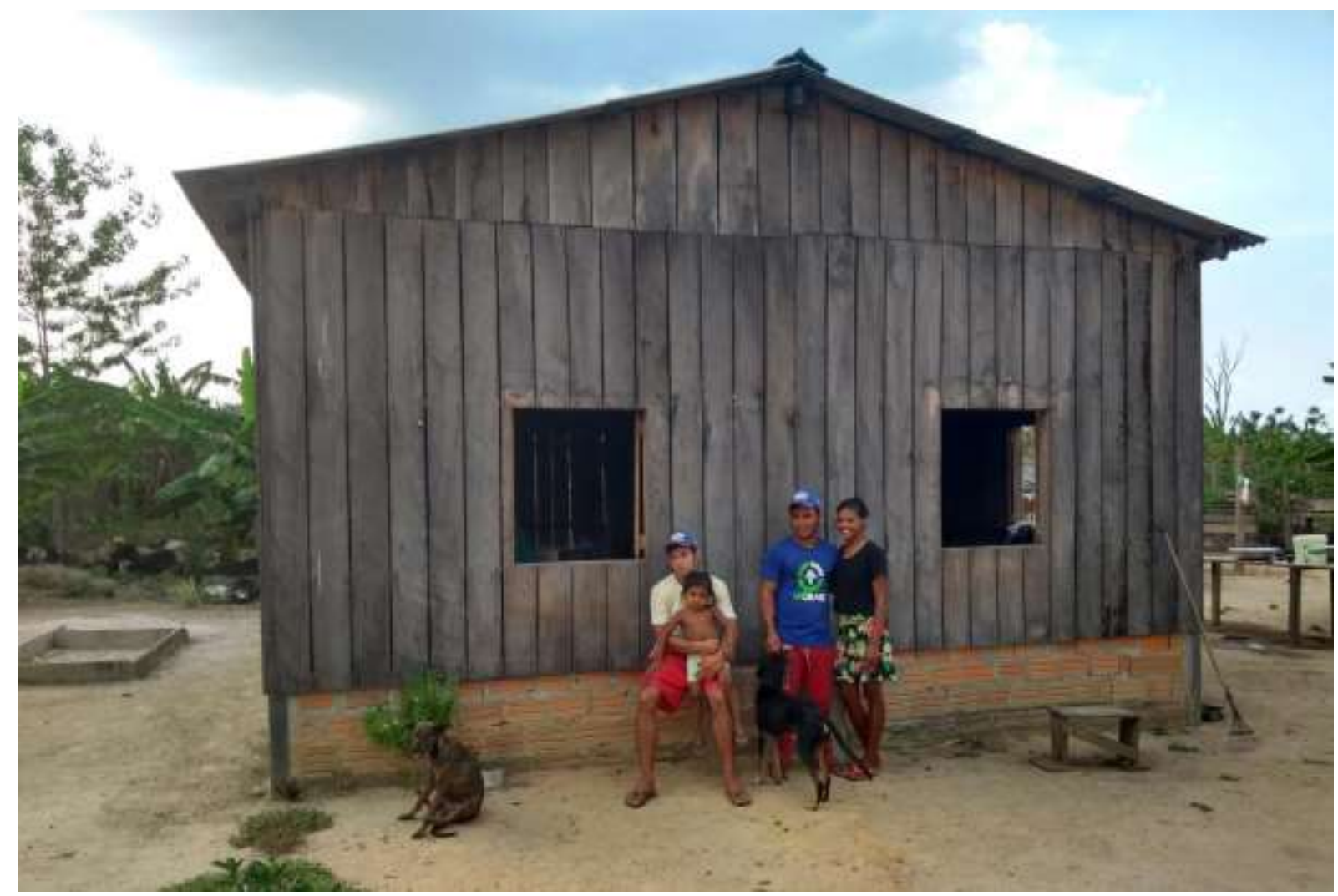

Fig. 11. Jovem família de lavradores no PDS Serra Azul. Sentado está tio e sobrinha, e à direita o casal.

Não raro, ouvimos narrativas de lavradores que extraem madeira de seus roçados por encomenda, ou que revendem o material diretamente às empresas interessadas: é outro elemento que entra em tensão com a tarefa de fiscalização reservada ao Estado. Quando não há inspeções do ICMBio e da Polícia Federal, caminhões cruzam a comunidade carregados de toras, embora o trânsito, como afirmam os entrevistados, tenha se reduzido desde 2016. Entendemos que as transações com as madeireiras são uma oportunidade para os assentados embolsarem dinheiro, como relação que excede o âmbito legalidade. Mesmo se complementar à lavoura, a chance de contrair tais proventos serve para assinalar a mobilização do trabalho (Gaudemar, 1977) dos lavradores da Serra Azul. É certo que o assalariamento não se generaliza como forma, mas o trabalho continua a ser mobilizado objetivamente em relação às personificações dos conflitos locais. A violência fica localizada no contexto da monetarização e autonomização que passa às costas dos sujeitos, mas mantendo na comunidade uma simulação de espontaneidade, de pronto confirmada, ou desejada, pela classificação de perfis de agricultor pelo Estado. 
4.3.1. O Estado e as novas estratégias de controle do acesso a terra: o Programa Terra Legal e o PDS.

"Aí depois que nós tava aqui [...] que o Incra marcou o PDS”. Lúcio, da Matona, coloca com tal afirmação que os agricultores da comunidade São Francisco, chegando anos mais tarde à localidade em disputa, desrespeitam os ocupantes mais antigos, uma vez que o PDS não poderia ser implantado em área habitada. Daí um conflito candente entre as duas associações da Serra Azul. As discordâncias são balizadas, sobretudo, na maneira como que se deve distribuir a terra. Visto defenderem a legalização de lotes de 100 ha pelo Programa Terra Legal, Lúcio e a associação da Matona (Associação dos Produtores da Matona Serra Azul - Promasa) se posicionam contrários ao modelo do PDS, de 20 ha de terreno mais 80 ha de reserva legal. A justificativa é que a reserva não pertenceria aos assentados, e, podendo desmatar apenas $20 \%$ de seus terrenos, ficariam tão confinados que não sustentariam suas famílias. Assim, melhor seria manter sua centena de hectares com $80 \%$ da mata "em pé" no fundo do roçado. A posição é que a autenticação do assentamento invalida a posse efetuada previamente, pois seria vetada a alternativa da titulação e do usufruto da propriedade de 100 ha. Mas o PDS teria se sobressaído porque, para os entrevistados, os moradores de São Francisco pactuaram com os madeireiros na divisão dos campos e conquista da área.

Enquanto isso, Paulinho alega que o Terra Legal respaldaria a concentração fundiária:

Qual é a condição mais conflituosa hoje? Um grupo de gente aqui acredita e sabe que não tem outra forma de sobreviver aqui dentro se não for por dentro do assentamento. Um grupo de gente, principalmente mais lá de fora, da Matona, eles pleiteiam a legalização da terra pelo Terra Legal, titulação individual; [se] você tem mil hectares, fica com mil, se tiver 10 mil, fica com 10 mil... Então não, eles pleiteiam 10 mil porque sabem que não vão aceitar, mas pleiteiam áreas menores, então eles pleiteiam dentro do assentamento. [...] Hoje, nós temo uma reserva legal invadida [...] Tem vários debate junto com a polícia federal, mas nós ainda não conseguimo qualificar essa turma.

D.L.: Não sabem se são de fora...

Paulinho: Não, sabem que são de fora. Mas tem uns daqui da região. E aí, esse pessoal são ligado a Matona, a Promasa, né. E aí gera um confronto entre as família assentada, entendeu [...] E aí quando os cara começam a andar, começam a ouvir, o conflito começa a soar, né. Aí, como a gente fica mais a frente, a gente começa a ser o mais marcado, né. Aí: "olha, a gente não consegue titular a terra porque o Paulinho tá atrapalhando". 
Para o entrevistado, quem já possui grandes extensões de terra logra, com o programa, a legalização destas, para tanto movendo estratégias dentro da Promasa, valendo-se de alguns dos filiados e perseguindo quem contesta.

Segundo observado em campo, alguns donos de propriedades não muito extensas no Sul do país ou do Pará vislumbram oportunidades de tomarem terras na Amazônia. Assim acontece com alguns membros da Promasa, donos de algumas centenas de reses de gado; a título de exemplo, uma personagem conhecida nos arredores como Paraguai. Mas também ocorre a grilagem de grandes dimensões de terra, como acontecido com os expulsos com a efetivação do PDS. Entre os que ficaram, contamos Baiano e Rube, invasores da reserva legal do projeto, e Djalma, que abriu um extenso ramal ao largo do rio Maicuru e abrigou milhares de "bois piratas" (bois não declarados) no interior da Flona da Mulata. Português é um grileiro e madeireiro sobre quem pouco se sabe, salvo que é oriundo de Novo Progresso e ficou muitos anos sumido. De madeireiros que já não residem na área, ouvimos muito sobre Jovi, Burra Loura e Ciro, que já fora grande influenciador das tomadas de decisão na Matona e é suspeito de mandar assassinar Paulinho. Isso para não citarmos os jagunços que ora ou outra, ostentando suas armas, ainda transitam pelo PDS: Velho Paulista, Velho Divino, Índio Branco, Índio Preto.

Em cada comunidade, reparamos usos do solo ligeiramente discrepantes. Em São Francisco, o mais comum são terrenos que se assemelham em tamanho e no emprego familiar da força de trabalho na agricultura. Já na Matona, sem exclusão da presença de pequenos lavradores, distinguimos campos desmatados mais extensos, lotados de gado, e alguns tratores de roda, estacionados junto à residência de alguns moradores (Fig. 12). A questão é que não se engajaria entre os sócios da Promasa instrumentos de convencimento - para sermos, no mínimo, eufemísticos - que façam concordar os lavradores com as objeções de grileiros e madeireiros no que respeita à propriedade da terra? Quer dizer, a proposta de titulação tem de parecer vantajosa para todos, e nesse aspecto a opinião dos associados à Promasa é unânime. Claro que, apesar de forte oposição à concentração fundiária, não se isenta de vigorar entre os sócios da AASA conluios com madeireiras. Tampouco deixam muitos dos moradores da Matona de se posicionarem abertamente contra a grilagem e as madeireiras, optando contudo pela titulação da propriedade. E é justamente pela imprecisão que configura as relações e a postura das personas contextualizadas que não se trata o problema de qualquer julgamento moralista. 


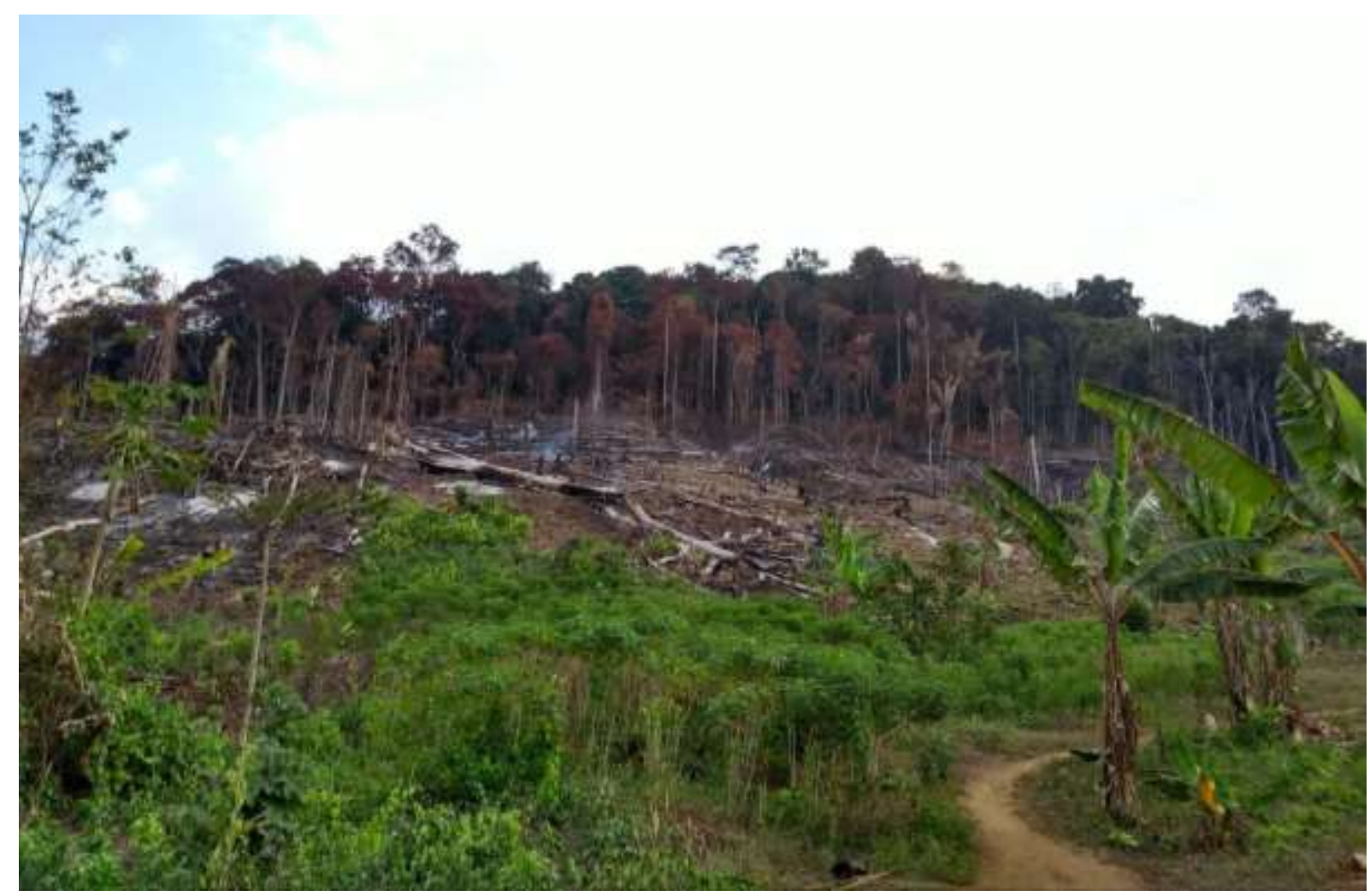

Fig. 12. Vegetação devastada em Matona, no PDS Serra Azul.

O Programa Terra Legal, preterido pela Promasa, tem como meta, conforme o site do instituto responsável ${ }^{128}$, a regularização de 57 milhões de ha da Amazônia Legal, legitimando a posse da terra, "oferecendo segurança jurídica, inclusão produtiva e acesso a políticas públicas" por parte dos beneficiários, contribuindo para a redução dos conflitos agrários, da grilagem e do desmatamento ilegal. Um artigo de Thereza Menezes (2015), direcionado ao exame da efetivação do programa no sul amazonense, levanta que a legalização dos lotes é gratuita se atinge até quatro módulos fiscais, ou, para medidas maiores, referenciada por preços de mercado (ibid.: 113). O Sistema Nacional de Cadastro Rural (SNCR) e o MDA indicam que as parcelas beneficiadas são, em grande parte, inferiores aos quatro módulos referidos, atendendo às famílias de posseiros. Para estas, o programa requisita não ter outro imóvel rural, a prática de cultura efetiva, a prova de que a ocupação do terreno é anterior a dezembro de 2004 e a ausência de benefício por programa de reforma agrária (ibid:: 114).

Poderíamos, nesses termos, defender que o Terra Legal surge da tentativa de controlar a ocupação fundiária da Amazônia em seu feitio concentrador. Todavia, o artigo declara que a transferência, com licitação, de terras federais para particulares é mais recorrente nos lotes

\footnotetext{
128 <http://www.mda.gov.br/sitemda/secretaria/serfal/apresenta\%C3\%A7\%C3\%A3o>. Acesso em: 21 de agosto de 2018.
} 
maiores $^{129}$ (ibid.: 114). O confronto de dados sobre estratificação fundiária suscitaria críticas de que o governo ensejaria a regularização de terras griladas e desmatadas. Ainda mais porque o prazo para negociação dos títulos difere de acordo com a dimensão do terreno, sendo de uma década para áreas de até quatro módulos fiscais e três anos para as que ultrapassam tal medida. A tese, pois, é que a lei incentiva a rápida mercantilização da terra (ibid:: 115). Na visão da autora, a legalização impede o retorno de terras ao Estado, que poderia direcionar as parcelas à criação de UCs e à proteção de "grupos tradicionais"130 (ibid.: 115). O governo rebateria as críticas afirmando que a regularização massiva permite a substituição de um mercado ancorado na grilagem, e mesmo no trabalho escravo, por um mercado fundiário formal, "garantindo segurança aos investidores e tornando efetiva a responsabilização jurídica em caso de desrespeito a leis trabalhistas e ambientais" (ibid.: 116).

Em nossa leitura, o discurso oficial quanto ao programa esclarece uma posição que busca a juridificação da terra em resposta à expropriação por parte de ameaças e da grilagem, garantindo a propriedade ao posseiro. Por outro lado, o caminho fica aberto para processos de expropriação decorrentes do mercado, porquanto regula as transações, que podem parecer da livre iniciativa do lavrador. No mais, o programa convém para a autonomização da terra como mercadoria. Nas iniciativas em torno do PIC Monte Alegre desde a década de 1970, tanto a regularização quanto a confusão em torno da titulação original das parcelas incentiva processos de compra e venda, cujos desdobramentos já abordamos. Mas claro: as consequências do Terra Legal, que almeja desburocratizar a autenticação, apenas seriam viáveis de mensuração com o estabelecimento do programa na área.

Menezes examina alguns efeitos desse projeto no sul do Amazonas, onde "mudanças significativas na configuração territorial” foram provocadas (ibid.: 118). Ela observa, nos últimos anos, o aumento do preço da terra, além de alterações

na tentativa de delimitar lotes de modo a corresponder ao tamanho do módulo fiscal, na expulsão ou coação violenta de pequenos produtores para vender ou deixar a terra, no avanço do desmatamento, visto que a regularização é publicamente percebida como um momento que precede o possível aumento da fiscalização ambiental, e, finalmente, na fragmentação de propriedades

\footnotetext{
129 O tamanho máximo da terra passível de regularização sem licitação na Amazônia cresce desde 1993, quando era de 100 ha, para 500 ha em 2005 e finalmente para 15 módulos fiscais em 2009 (Menezes, 2015: 111-2).

130 "O ato de regularização é um impedimento a ações de reintegração de posse e retorno da terra à União, portanto o Programa Terra Legal abriu a possibilidade de subtrair do controle do Estado um vasto conjunto de terras públicas que poderiam ser demandadas e potencialmente destinadas à criação de unidades de conservação ou estatutos territoriais voltados à proteção de terras tradicionalmente ocupadas ainda não identificadas ou destinadas" (Menezes, 2015: 115).
} 
extensas entre parentes, de forma a se enquadrar na legislação que assegura a regularização (ibid:: 118).

O interessante é como a execução de procedimentos, por assim dizer, ilícitos, intervém no mercado fundiário formal e na propriedade privada, empregando novas táticas de coerção no acesso a terra. Além dos já listados, nossa interlocutora descreve como agentes do Estado têm buscado convencer "comunidades tradicionais" que demandam a criação de Reservas Extrativistas - para nós, não dificilmente transponível para a criação dum PDS -, de que a regularização via Terra Legal é a mais simples, rápida e disponível para obtenção de segurança territorial (ibid.: 124). A formalização da grande propriedade fundiária no mercado ocorre de forma a mobilizar representantes do Estado na descaracterização dos assentamentos, para em seguida expropriar populações com pretexto de protegê-las da violência, e por fim questionar a legitimidade da presença destas nas terras almejadas pelos grileiros (ibid.: 128).

Em vistas disso, a autora objeta que o programa busca garantir que "o excedente de terras públicas da Amazônia fique legalmente reservado à expansão [...] da fronteira do agronegócio", diversamente do "mosaico étnico-ambiental que redesenhou o mapa da Amazônia", e que tornou terras públicas "tradicionalmente ocupadas ou voltadas para a agricultura familiar" (ibid.: 129).

É uma designação que notamos no esforço de regulamentação do PDS Serra Azul, frente ao qual interpretamos mudanças na administração estatal. Lembremos que o PDS é uma modalidade de assentamento instituída pelo Incra que não prevê a propriedade da terra, senão a concessão de certificados de uso coletivo sob responsabilidade da União; emite-se, notadamente, o Certificado de Concessão de Uso (CCU) e o Certificado de Concessão de Direito Real de Uso (CCDRU). O beneficiário tem os mesmos direitos de usufruto que um proprietário, embora não possa vender seu lote; além disso, lhe é concedida uma parcela de reserva legal coletiva, na qual um plano de manejo direciona que recursos florestais podem ser explorados. O Incra define que o PDS é concebido "para o desenvolvimento de atividades ambientalmente diferenciadas", dirigido para "populações tradicionais", e prevê a construção de infraestrutura básica - estradas de acesso, água tratada e energia elétrica -, com aporte de recursos de crédito $^{131}$.

Em 2006, são implantados nas áreas de várzea de Monte Alegre treze Projetos de Assentamento Agroextrativistas (PAE), voltados à assistência das populações ribeirinhas e com emissão de certificados de uso. É verdade que permanece a formação de assentamentos

\footnotetext{
${ }^{131}$ <http://www.incra.gov.br/assentamentoscriacao>. Acesso em: 18 de agosto de 2018.
} 
nos antigos moldes, como ocorre com a fundação de cinco Projetos de Assentamento (PA) em 2005 sobre terrenos que já haviam sido loteados pelos moradores ${ }^{132}$. Todavia, é notável em maior dimensão a difusão da variante de desenvolvimento sustentável, distante das formas de assentamento historicamente planejadas em território nacional e na Amazônia, mais direcionadas para a colonização e titulação individual da terra.

Salvo engano, o interesse tem passado da propriedade e seu respectivo estatuto jurídico para a questão do uso por "populações tradicionais", previsto o manejo de recursos florestais e aquáticos. Acentuamos, em particular, que os antigos projetos de colonização deslocavam famílias, amiúde de locais distantes, para o estabelecimento de trabalhadores de frentes onde se buscava formar um mercado de trabalho e de terras. Com o PDS pelo menos, nos parece que o interesse é de amparo às ditas populações tradicionais para que estas permaneçam junto a terra, e tanto menos para que componham um corpo nacional de força de trabalho disposta para exploração. Com tal avaliação, queremos dizer que o próprio modo com que o Estado gere sua população se metamorfoseia, tratando como "tradicional" ou “familiar" a reprodução dos lavradores, face à capacidade do capital coagir o trabalho nas atuais circunstâncias. O Estado atua tanto nesse sentido quanto no favorecimento da expansão de uma fronteira pautada na grande propriedade fundiária e na produção de commodities agrícolas.

4.3.2. Como a fronteira pecuário-madeireira avança recentemente para a Calha Norte paraense?

Resgatando a entrevista com Paulinho, vemos que a Serra Azul é preliminarmente demarcada por fazendeiros de origem sulista, para ser grilada visando à exploração pecuária e madeireira. Após um sucesso parcial na reivindicação do PDS pelos lavradores, grande parte dos invasores regressa para as cidades paraenses onde já detinha propriedades, como Novo Progresso e Uruará. Jairo, por seu turno, é gaúcho e mora por mais de treze anos no norte do Mato Grosso, atravessando por Santarém para Monte Alegre em 2003, comprando terras na Canp e no Perímetro e transferindo para seu nome os títulos de propriedade. Ambos os casos representam a locomoção de médios e grandes proprietários por um corredor visivelmente demarcado pela rodovia Cuiabá-Santarém (BR-163), em vias de pavimentação. A estrada, por

\footnotetext{
132 São eles: PA Maripá, PA Baixão, PA Moriçoca, PA Vai-quem-quer, PA Terra Preta e Olho d’Água, PA Cristo Rei; PAE Cuçaru, PAE Nazaré, PAE Curralinho, PAE Cuieiras, PAE Costa do Amazonas, PAE Piapó, PAE São Diogo, PAE Cauçu, PAE Paituna, PAE Região dos Lagos, PAE Jacarecapá, PAE Jaquará, PAE Aldeia.
} 
si mesma, não explica tal deslocamento, mas configura, no trânsito em seu eixo, parte do processo de avanço da fronteira pecuária e madeireira.

O texto de Ariovaldo U. de Oliveira (2005) sobre a Cuiabá-Santarém busca retomar o movimento de avanço da fronteira do norte mato-grossense, no fim da década de 1950, à expansão pecuária, madeireira e da cultura de grãos em direção à Santarém nos anos 1990. Ele vai descrevendo como a expansão territorial do latifúndio na faixa circundante da rodovia, e anteriormente à construção desta, é ancorada na grilagem, mais especificamente na procuração e despacho de títulos falsos que abnegam a presença de indígenas e posseiros, violentamente expulsos da área (ibid.: 90). Entrementes, as frentes passam a ser integradas basicamente por empresários do Centro-Sul do país e corporações estrangeiras, atraídos pelos incentivos fiscais dos planos de desenvolvimento regionais e introduzindo, sobretudo, projetos privados de colonização (ibid.: 92). A instalação desses projetos derivaria de fatores diversos, a saber, da transformação na agricultura nacional, da necessidade de trabalho para viabilizá-los, dos interesses dos latifundiários e das contradições da agricultura expressas em outras partes do Brasil (ibid.: 96). O foco da análise é na combinação contraditória de causas estruturais, ou, em outras palavras, na "lógica de desenvolvimento capitalista que impõe simultaneamente o mundial, nacional, regional e local" (ibid.: 97). É então determinante da colonização, em nossa leitura da publicação, a totalidade da reprodução do capital, apreendida por determinada contradição de escalas de territorialização.

No Norte de Mato Grosso, a colonização é responsável pelo rápido surgimento de cidades - mais de cinquenta, em pouco mais de duas décadas - e por óbices decorrentes da regularização fundiária (ibid:: 98-9). De acordo com Oliveira, muitos projetos apresentavam problemas quanto aos títulos que ostentavam, facilitando a investida da grilagem (ibid.: 100) e de outras fraudes, motivadas pela invasão de terras. Entre as práticas mais dolosas, estava a venda de títulos provisórios ou por procuração e a venda por protocolo, na qual a empresa comercializa um lote que nunca possuiu (ibid.: 104-6). Dessa feita, o autor reproduz um excerto de documento redigido pelo governo de Mato Grosso, onde se lê que, aberta a BR163, começam a surgir os primeiros grandes núcleos colonizadores; Sinop é o primeiro deles, seguido por municípios como Sorriso e Nova Mutum (ibid.: 108). Este último fora fundado pelo grupo Herbert Levy nas ourelas da BR, em área superior a 100000 ha e desde o princípio marcado pelo cultivo mecanizado de grãos. Os lotes, de 50, 250 e 500 ha, vendidos em pares, eram amiúde ocupados por produtores médios capitalizados de fora do estado (ibid:: 114). 
Mais adiante, o geógrafo explicita que, desde a década de 1980, a área cultivada de soja se expande impetuosamente em Mato Grosso e no Pará. Os dados coletados exibem que de 3 ha de área cultivada do grão em MT e 1 ha do mesmo no estado nortista em 1975, a cifra salta para, respectivamente, 822821 ha e 397 ha dez anos depois, e para 2,8 milhões e 2,3 mil ha em 2000 (ibid.: 137-8). No mesmo período, nos municípios banhados pelo rio Tapajós, a debacle do garimpo é concomitante à grilagem de terras devolutas por pecuaristas oriundos, em sua maior parte, do norte de Mato Grosso (ibid.: 145). No argumento, os projetos de colonização gestaram contraditoriamente um grupo de grileiros a ocupar o sudoeste paraense e o leste do Amazonas, passando estes, inclusive, a controlar o comércio de ouro na área (ibid.: 145). Isso para não ser mencionada a extração ilegal de madeira, concentrada nos limites avizinhados da rodovia - com destaque para Novo Progresso e Castelo dos Sonhos.

Para nosso interlocutor, o asfaltamento da Cuiabá-Santarém em toda sua extensão influenciaria o avanço da fronteira madeireira (ibid.: 146). Portanto,

o binômio madeira-pecuária está no centro do processo de grilagem no sudoeste do Pará. A exploração da madeira funciona como uma espécie de acumulação primitiva que permitirá ao grileiro juntar dinheiro para investir no cercamento e controle da terra que pretende abocanhar. O dinheiro também servirá para formar as pastagens, pois a pecuária é o instrumento de alegação da "posse produtiva" das terras públicas griladas (ibid.: 146).

Acumulação primitiva que, sustentamos, só faz sentido da ótica do grileiro como proprietário de capital, permitindo o início dos negócios a partir da exploração madeireira. Tomada a totalidade do processo, teríamos que ter em mente, adiantando a análise, a atual crise do processo fundamental de valorização do capital (cf. cap. 4.4).

Novo Progresso nasce por ocasião da BR-163 e da descoberta de jazidas auríferas em 1983. Os terrenos devolutos são loteados por um grileiro e vendidos aos que para lá afluíam, sendo o desenvolvimento econômico do município balizado na extração clandestina de madeira (ibid:: 147). Como o site oficial do município relata o acontecido é alvo da indignação de Oliveira: aqui, a revelação da ocorrência de ouro aparece como um acaso, e o loteamento e migração como obras da ação, digamos, "pioneira": primeiro, um sujeito decide cercar a área; depois, outro estabelece seu comércio, e assim por diante.

Ora, o pioneirismo já fora criticado na obra Fronteira, de Martins (2014), como uma espécie de idílio que negligencia conflitos, em função da harmonia na criação de uma "nova sociabilidade" (ibid.: 10). Em vez disso, o autor preza pela "vítima" como a figura explicativa da fronteira, que mostra o outro e a liminaridade do encontro com essa alteridade (ibid.: 10). 
A fronteira, pois, teria "um caráter litúrgico e sacrificial, porque nela o outro é degradado para, desse modo, viabilizar a existência de quem o domina, subjuga e explora" (ibid.: 11) ${ }^{133}$.

Observamos no texto de M. Torres (2005) - publicado no mesmo livro que o texto de Oliveira até há pouco decupado - formas variegadas de gestão da violência do Estado aliado a grileiros nas áreas que circundam a BR-163. O autor demonstra como milícias particulares fazem ali as vezes da segurança pública, organizando blitz nas estradas, apreensões, despejos, torturas e execuções com anuência da polícia local (ibid.: 285). Outras vezes, é a polícia que serve como pistoleira do grileiro que a financia - fornecendo do abastecimento das viaturas à alimentação e moradia dos policiais -, para desferir ameaças contra a população e criminalizar os posseiros (ibid.: 291-2). Como as terras amiúde não são tituladas, o processo de regularização tende a favorecer os grileiros (ibid:: 296), que, com o anúncio do asfaltamento da rodovia e o possível aumento do preço da terra a ser ocupada com campos de soja, recrudescem o aparato de violência (ibid.: 298). Desse modo, em Novo Progresso, a atuação dos madeireiros, facilitada pela parca organização posseira, antecede a chegada dos pecuaristas, fomentando o mercado fundiário local (ibid.: 299).

Sustentamos que a cumplicidade da polícia com grandes fazendeiros, assim como as fraudes reportadas, devem ser esposadas como um arranjo da fronteira na área, e não como incongruência do Estado ou falta de mediação da instituição. Extravasando o escopo da agência do Estado, o percurso é de efetivação de uma ordenação fundiária concentrada para viabilizar a exploração madeireira e pecuária precedente à expansão da cultura sojeira no caminho aberto pela BR-163. Visto que o processo desemboca na produção de grãos como commodities agrícolas, vale salientar a mediação do capital financeiro ${ }^{134}$, ainda que não seja exatamente o verificado na Calha Norte paraense. A fronteira é confrontada com formas de ocupação do território arraigadas na conservação e na gestão das "comunidades tradicionais" por políticas de assentamento, simultaneamente operando certa conivência com a grilagem.

\footnotetext{
${ }^{133}$ Se fizermos ao menos uma comparação entre este texto de Martins e o publicado em 1975 (que tratamos no cap. 2.3), ela consiste num maior enfoque à figura da vítima, com uma apreciação geral de mais de trinta anos de pesquisa na fronteira amazônica. No capítulo $4 \mathrm{em}$ especial, o autor retrata muitos dos temas estudados durante sua vida intelectual, focando, principalmente, na economia de excedente, em resposta à acusação de ele ter retratado um campesinato a partir da subsistência. Outrossim, ele ratifica a ideia de frente de expansão e frente pioneira não como etapas, mas como ângulos de análise da fronteira.

${ }^{134}$ A. de Oliveira (2005: 176-80) chega a abordar rapidamente a função de grandes empresas agrícolas, como a Cargill (que possui um grande terminal portuário em Santarém e estuda a possibilidade de construir mais um em Itaituba), no financiamento de médios produtores na faixa da BR-163. Em campo, foi-nos explicado por técnicos do Incra de Santarém que as transações entre sojeiro e companhia são calculadas por créditos em commodities reversíveis em dinheiro ou em insumos, conforme desejo do produtor. Para uma análise mais pormenorizada do processo de comoditização na agricultura, cf. Pitta (2016), que a trata da perspectiva da formação do complexo sucroalcooleiro no interior paulista.
} 


\subsection{Conservação, acumulação primitiva e crise}

O plano de manejo da Flota do Paru, obedecendo ao Sistema Nacional de Unidades de Conservação (Snuc) e à Lei de Gestão de Florestas Públicas (Lei 11 284/06), prevê a exploração de recursos florestais madeireiros e não madeireiros e a realização de serviços florestais por parte de quem o desejar (Pará, 2010: 39). Estabelece, para tanto, a abertura de editais para licitar as empresas consideradas aptas ao plano de conservação. Já para as "comunidades tradicionais" do interior e dos arredores da floresta, espera formalizar termos de uso, assegurando condições para a satisfação das necessidades materiais, sociais e culturais destas (ibid.: 39). Não à toa, o documento retrata a UC como detentora de

alto potencial florestal para produtos madeireiros e não madeireiros por abrigar grande estoque de espécies madeireiras de valor econômico e reservas de castanhais, além de ecoturismo (ibid:: 20),

evidenciando, para nós, o interesse por certa forma de uso da terra para acumular capital. Que tipo de acumulação se trata revela algo com o que precisamos, doravante, nos ocupar.

O plano destina a concessão de Unidades de Manejo Florestal (UMFs) a empresas interessadas na extração madeireira pelo prazo de quarenta anos. Os ganhos devem ser tributados e repartidos entre os municípios da Flota, bem como convertidos para um fundo de desenvolvimento florestal estadual (Fundeflor) e para o órgão gestor da floresta, o Instituto de Desenvolvimento Florestal do Pará (Ideflor-Bio) ${ }^{135}$ (ibid.: 27-8). Com a abertura do edital, três companhias conquistam o direito de manejo: a primeira delas sequer chega a operar, enquanto a segunda, a Semasa, é embargada pelo transporte de madeira fria para Santarém integrando as fraudes relatadas no cap. 4.3 -, sendo a única restante a RRX Florestal.

A empresa é subsidiária da RRX Mineração e Serviços Ltda., com sede em Rio Bonito (RJ), e se serve de três UMFs da Flota, num total de 91 556, 45 ha de concessão. No resumo público de seu plano operacional, consta "promover o crescimento econômico [...] respeitando e fomentando os valores sociais, ambientais e culturais das comunidades do entorno" (RRX,

\footnotetext{
135 “Também foi criado o Fundo Estadual de Desenvolvimento Florestal (Fundeflor), que tem o objetivo de promover, fomentar e apoiar o ordenamento, a diversificação, a verticalização e a dinamização das atividades sustentáveis de base florestal (lei 6.963/2007, art. 13). Esse fundo terá como fonte, conforme o art.14, os recursos oriundos das concessões, contribuição financeira dos beneficiários, orçamento estadual, transferência da União, doações e contribuições financeiras de pessoa jurídica ou física e retorno de aplicações financeiras e amortizações, juros, retornos e qualquer renda resultante de operações realizadas com recursos do Fundo no Estado. 0 art.. 15 diz que o recurso será distribuído da seguinte forma: $30 \%$ destinados a cobrir as despesas de aparelhamento e funcionamento do Ideflor; $30 \%$ destinados aos municípios onde estão situadas as áreas florestais de domínio estadual submetidas ao regime de concessão ou exploração de compensação de reserva legal; e $40 \%$ destinados a programas, ações, projetos ou atividades aprovados pelo Ideflor ou executados sob sua coordenação" (Pará, 2010: 27-8).
} 
2017: 3). Entre seus objetivos, aparece a realização da exploração madeireira "de maneira sustentável", aplicando técnicas de manejo e exploração de impacto reduzido e aperfeiçoando a produção. Isso sem deixar de "conduzir à regeneração natural da floresta" por meio de tratamento silvicultural, esperando "utilizar a mão de obra local, proveniente principalmente das comunidades do entorno da unidade de manejo e/ou de Monte Alegre" (ibid.: 5).

Quando estivemos em campo, a companhia procurou realizar reuniões com os moradores da Serra Azul, construindo com estes um mapa mental do PDS (Fig. 13) e debatendo reivindicações. Entre os requerimentos levantados, o mais urgente fora a melhoria nas condições de tráfego, explicitando a centralidade, para aqueles moradores, do escoamento da produção. As opiniões relativas à atuação da madeireira são, contudo, divididas: enquanto, via de regra, os sócios da AASA não têm atritos com a firma, os membros da Promasa creem que os recursos da Flota são retirados sem se ter nada em troca.

Os funcionários da RRX são, em sua maioria, operadores de motosserra e de tratores provindos de outras porções do Pará, que prestam serviços nos meses de estiagem. Paulinho relata que os lavradores não se interessam em trabalhar para a companhia, "até porque o salário pago não é tão alto", pois "no terreno ganha[-se] mais". Caso ocorresse o contrário, o por ele denominado "sentido da terra" se esgotaria ${ }^{136}$. Outro fator, enumerado por Itajury, é que os montealegrenses em geral não atendem às exigências da empresa, uma vez que necessária certificação técnica. Assim considerando, a reprodução familiar na terra é até segunda ordem mantida no PDS, mesmo que vista da ótica do cálculo monetário. A mobilização da força de trabalho (Gaudemar, 1977) desse morador, aliás, como temos colocado, deve ser encarada em outro registro, que não o do assalariamento. Senão, vejamos.

Num artigo publicado no Journal of peasant studies, Alice Kelly (2011: 683-4) busca mostrar como áreas protegidas criam e reproduzem os meios da produção capitalista e, através das práticas da conservação neoliberal, estão aptas a se tornarem elas mesmas capital na forma de serviços ambientais, espetáculos e estoques genéticos ${ }^{137}$. Ao mesmo tempo, a conservação é posta como "forma particular de acumulação primitiva que envolve enclosures e espoliação da terra e de recursos naturais" ${ }^{138}$ (ibid.: 683).

\footnotetext{
136 “A gente como associação defende até que o pessoal não vá mesmo. Porque se o pessoal do assentamento for trabalhar na firma, acabou o sentido do assentamento. Nós vamo produzir pra quem? O sentido da terra mesmo, acabou. Mas a gente não precisa fazer essa campanha; automaticamente o pessoal não vão."

137 "I hope to show how protected areas create and reproduce the means of capitalist production and, through neoliberal conservation practices, are able to become capital themselves in the form of environmental services, spectacles, and genetic storehouses".

138 "I argue that we must examine how protected area creation is a particular form of primitive accumulation that involves both enclosure and dispossession of land and natural resources". Caso vasculhemos a literatura
} 


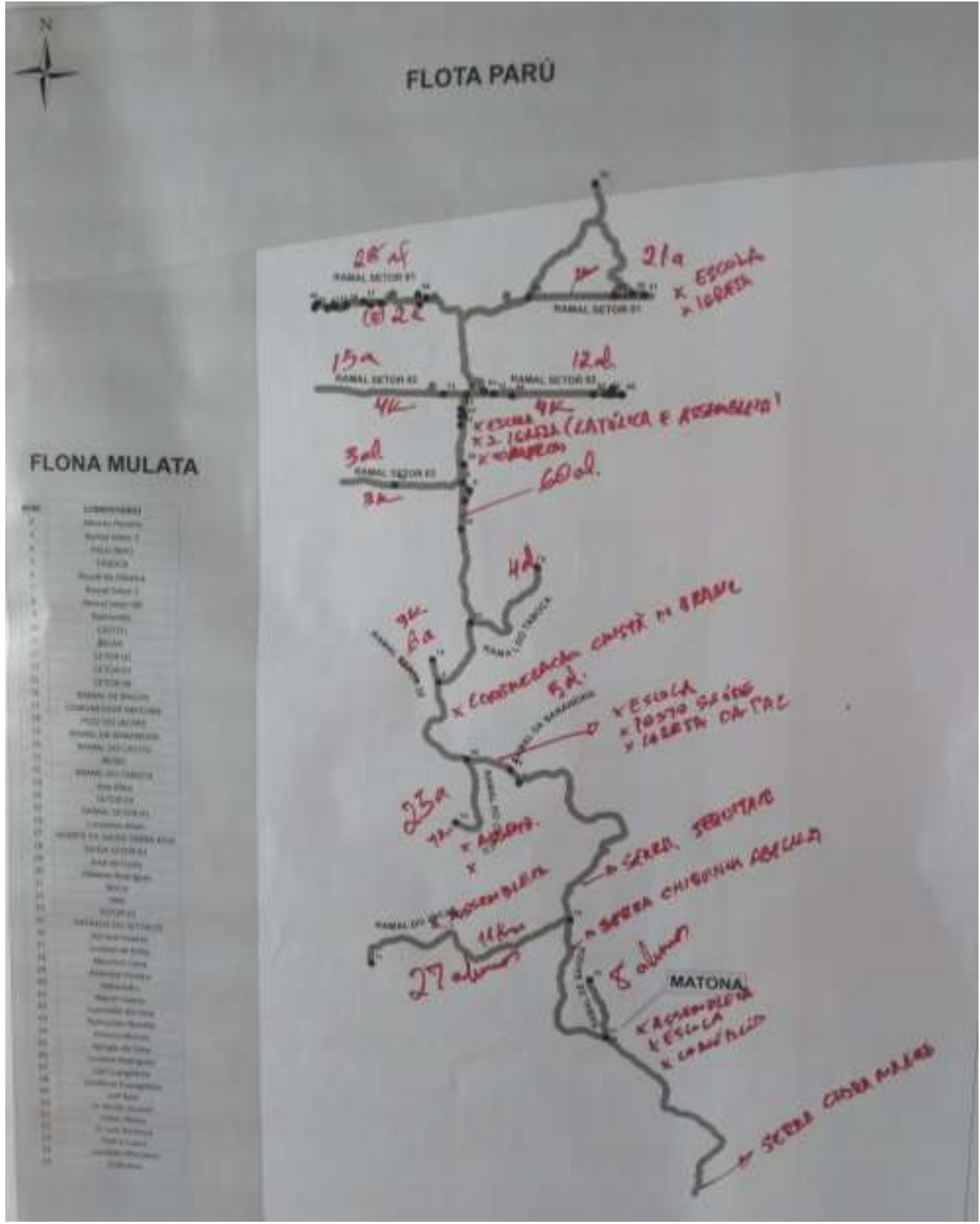

Fig. 13. Mapa mental do PDS, construído pelos moradores com a madeireira RRX.

Para a autora, a acumulação primitiva é um processo que persiste até hoje, se bem que com percalços diferentes, com novos agentes expropriadores (ibid.: 687), ampliando o alcance da economia de mercado ao criar as condições necessárias para a produção capitalista, assim assegurando suprimento de força de trabalho barata e de materiais (ibid.: 688). Áreas protegidas seriam exemplos da expansão da produção capitalista a novos espaços, excluindo

especializada, veremos que o termo "enclosures" é por vezes traduzido como "cercamentos", mas preferimos manter o termo em inglês por ser assim que Marx se refere ao processo em seu capítulo da A assim chamada acumulação primitiva, no original alemão e em português (MarX, I. I t. II, 1986, cap. XXIV). Já "dispossession", que literalmente seria tomado por "despossessão", é traduzido como "espoliação" devido ao diálogo com a teoria de Harvey (2014) travada pela autora e ao uso de tal termo na edição brasileira de $O$ novo imperialismo. 
as populações residentes ao passo que as puxa para a economia de mercado: os trabalhadores, divorciados de seus meios de produção, seriam forçados a venderem suas forças de trabalho (ibid.: 688). Reproduzindo West et. alli (apud ibid.: 688), nossa interlocutora afirma que a "conservação neoliberal 'precisa de biodiversidade ou natureza para transformar em mercadorias e nativos para transformar em trabalho". Mas a criação de força de trabalho poderia vir separada da acumulação por um longo interregno, só recentemente tornando-se capital as áreas assim apropriadas:

Apesar de historicamente áreas protegidas poderem ter sido criadas para motivos políticos ulteriores, tais como controlar grupos indisciplinados ou recalcitrantes, criando uma força de trabalho industrial disposta e subjugada, e protegendo recursos naturais valiosos, é apenas relativamente recentemente que estas áreas se tornam elas mesmas capital ${ }^{139}$ (ibid:: 689, tradução livre).

Pensando com esses termos, Kelly coloca que "propriedade privada não é necessariamente pré-requisito para acumulação privada"140 (ibid.: 689).

Sendo possível um grande intervalo entre a expropriação da população de uma área e a utilização dessa área como capital, quando nos voltamos à nossa investigação supomos que o problema seja mais tributário da impossibilidade da reprodução da população segundo o apossamento de "terras livres". Enquanto isso, a expropriação vigora na retaguarda do processo, mesmo que exista, da parte da conservação, uma intenção de conter o avanço da fronteira madeireira e agropecuária. A administração da força de trabalho nacional tem que se realizar por outros meios, o que parece ocorrer pela criação de assentamentos segundo uma “pauta de desenvolvimento sustentável” (Costa, 2007: 148) da parte de comunidades locais. Objetemos, sem embargo, que mesmo o manejo de recursos aprofunda a submissão ao mercado enquanto é esperado que, digamos, o meio ambiente seja protegido. A formação de áreas protegidas, à primeira vista, poderia ser criticada levando em conta os ganhos das empresas licitadas e a forma do repasse para as localidades vizinhas à Flota, além de se perguntar de como a força de trabalho poderia aqui ser empregada. Indo além, sustentamos a crítica da própria noção de transformação de espaços não capitalistas em capitalistas e da capacidade dessa mudança prover a acumulação.

\footnotetext{
139 "Though historically protected areas may have been created for ulterior political motives such as controlling unruly or recalcitrant groups, creating a willing and subdued industrial workforce, and protecting valuable natural resources, it is only relatively recently that these areas have become forms of capital in themselves".

140 "Here we see that private property is not necessarily a prerequisite for private accumulation". Os casos assim enumerados são os de privatizações e patentes de recursos genéticos, agências de turismo, direitos de imagem e ganhos de ONGs em acordo com grupos farmacêuticos e com donativos de empresas (ibid.: 690-1).
} 
Conforme a exposição de Kelly (2011), a “conservação neoliberal” se reproduz sobre procedimentos de acumulação primitiva, ou melhor, participa da construção do argumento, reconhecidamente, a tese da acumulação por espoliação de Harvey (2014) ${ }^{141}$. Trocando em miúdos, o enunciado do geógrafo britânico parte de sua inquietação de porque o capitalismo sobrevive por tão longo período, não obstante crises e reorganizações (ibid.: 77). Formulação que viria do registro de processos de sobreacumulação, como excedentes de capital - na forma de mercadoria, moeda e capacidade produtiva - e de força de trabalho (ibid.: 78). Para evitar tal desvalorização, seria preciso "descobrir maneiras lucrativas de absorver os excedentes de capital”, sendo opção "a expansão geográfica e a reorganização espacial”, indistinguível das "mudanças temporais em que o capital excedente é deslocado para projetos de longo prazo" que retardam a circulação do valor neles investido (ibid.: 78). Essa nomeada “ordenação espaçotemporal do capital” (ibid.: 79) dependeria de instituições de Estado e financeiras, no "papel mediador [...] em revezar o direcionamento dos fluxos de capital", pois que deteriam "o poder-chave de gerar e oferecer crédito" (ibid.: 97).

O autor considera que o Estado é o "mais capaz de orquestrar arranjos institucionais e manipular as forças moleculares de acumulação do capital" (ibid.: 111) ao prestar apoio ao capital financeiro, que "com frequência equivale à acumulação por outros meios" (ibid.: $114)^{142}$. Ele deriva de R. Luxemburgo que o capitalismo precisa perpetuamente de algo "fora de si mesmo" para estabilizar-se, de maneira a se apropriar de um exterior preexistente ou produzi-lo ativamente (ibid.: 118). O esquema é de uma "dialética interior-exterior", uma relação entre a "produção expandida [ampliada] do capital" e processos de espoliação como "molde da geografia história do capitalismo" (ibid.: 118). Harvey, assim, levanta uma "reticência" deixada por Marx, na medida em que deste se pressupõe a acumulação primitiva como já superada; a réplica é que o processo não é mais primitivo, mas fundado na espoliação (ibid:: 120-1) ${ }^{143}$. Os instrumentos de violência da acumulação primitiva estariam presentes até hoje, enquanto outros teriam sido "aprimorados" - leia-se, o capital financeiro (ibid.: 122). Em suma, a acumulação por espoliação resolveria a sobreacumulação ao

\footnotetext{
${ }^{141}$ A propósito, ela diz: "David Harvey argumenta em O Novo Imperialismo que o capitalismo precisa sempre se expandir para espaços onde a acumulação possa ocorrer, permitindo à economia de mercado se propagar" (Kelly, 2011: 688). ["David Harvey argues in The New Imperialism, that capitalism needs ever expanding spaces where accumulation by dispossession can occur, allowing the market economy to spread"].

142 "Tal como a guerra com relação à diplomacia, a intervenção do capital financeiro com o apoio do poder do Estado equivale com frequência à acumulação por outros meios" (Harvey, 2014: 113-4).

${ }^{143}$ Lencioni (2012: § 18) ressalta no termo "primitivo" que marca hoje a acumulação a barbárie e a brutalidade, pois não estaríamos mais na "pré-história do capitalismo"; hoje o capitalismo estaria plenamente desenvolvido, reproduzindo-se sobre si mesmo, mesmo que no seu seio combinado com relações não capitalistas.
} 
liberar um conjunto de ativos (incluindo força de trabalho) a custo muito baixo (e, em alguns casos, zero). O capital sobreacumulado pode apossar-se desses ativos e dar-lhes imediatamente um uso lucrativo (ibid.: 124).

Há ainda outra acepção recente do problema da acumulação. Saskia Sassen editou um livro abordando o que chama de expulsão e o surgimento e reprodução dessa lógica na economia política global atual (Sassen, 2016). Expulsão abrangeria uma miríade de aspectos fenomênicos, como expulsão de trabalhadores de programas de assistência governamental e de direitos antes adquiridos como cidadãos de uma nação soberana, expulsão da terra e do uso de recursos naturais, etc. Ela se refere, no geral, a "pessoas, empresas e lugares expulsos das ordens sociais e econômicas centrais de nosso tempo" (ibid.: 9). Mas que novidade carregaria tal conceito? Segundo Sassen, a grande singularidade existente é a inclusão de novos tipos de expulsão e sua escala de ocorrência (ibid.: 11). Igualmente novos são os instrumentos movidos, contando-se conhecimentos, técnicas e mecanismos organizacionais que, por sua complexidade, justificam a brutalidade sui generis das expulsões. Suas variegadas formas fenomênicas, que a autora circunscreve à "familiaridade", têm uma "afinidade sistêmica" entre si, à qual subsistem "tendências subterrâneas" que são "de difícil interpretação segundo nossas ferramentas usuais de análise" (ibid.: 16).

Tais tendências são alusivas a mudanças na economia global iniciadas na década de 1980. Para Sassen, duas são, a partir de então, as mudanças mais significativas: a primeira consiste na transformação de enormes e crescentes áreas do planeta em zonas para operação econômica, assumindo a forma da terceirização de serviços, administração e equipamentos; aqui, as cidades globais são espaços estratégicos para a operacionalização dessas funções econômicas (ibid.: 17). A segunda mudança reside na cidade global como locus do setor financeiro, acionando artifícios complexos de securitização - a exemplo do mercado de derivativos -, que financeirizam cada vez mais setores da economia (ibid.: 18). É um salto qualitativo definido não muito diversamente da relação do "capitalismo tradicional" com as “economias pré-capitalistas", já que arraigada na extração e destruição, enquanto cada vez mais pessoas são excluídas do sistema como produtoras e consumidoras (ibid:: 18). As tendências alegadas "não são anômalas, nem são o resultado de uma crise. São parte do atual aprofundamento sistêmico das relações capitalistas" (ibid.: 19, grifo nosso), sendo a exclusão parte da multiplicação dos lucros de certos setores econômicos.

Diante disso, podemos sugerir que em Harvey (2014) o capital financeiro e o Estado, como mediadores da reprodução do capital, são determinantes duma nova fase do capitalismo, 
que sustenta a espoliação como elemento que não só reitera como expande o capital em sua crise, projetando para fora de si o que deve ser apropriado. Neste sentido em específico, a espoliação, relacionada à reprodução ampliada do capital, explicaria a expansão da fronteira enquanto esse mesmo artifício pode se reiterar infindavelmente. Em Sassen (2016), a nova fase é bem marcada pelas expulsões, ocorridas, inexoravelmente, a partir de modificações alicerçadas na finaceirização e na administração das funções econômicas.

Por sua vez, na exposição do que intitula como "teorias da colonização mais recentes", R. Scholz (2016: s/p) ressalta como a reprodução capitalista é fundada em uma acumulação imanentemente crítica. A justificativa da autora é endossada em citações de Kurz (2014) em que a crise do capital em seu período de formação diverge do capitalismo já constituído. Neste, o movimento autorreferente do capital se realizaria como contradição em processo (Kurz apud Scholz, 2016), sendo o termo tomado dos Grundrisse de Marx. Para sermos mais exatos, a passagem de Marx (2011: 588) consiste em que o capital se desenvolve reduzindo o que é posto como a única fonte da riqueza, o trabalho ${ }^{144}$. Para Scholz (2016: s/p), é diferente tratar o capitalismo como "regresso do mesmo" do que considerá-lo como "movimento direcionado" a um fim em si. Logo, a colocação não é aquela da apropriação externa de um princípio criado internamente, como em Harvey (2014). O aprofundamento das relações capitalistas mediante expulsões (Sassen, 2016) também seria criticado por Scholz (2016), pois isso significaria a própria expulsão do trabalho como fundamento da riqueza.

É verdade que ao concordar com Kurz (2014), Scholz (2016: s/p) aceita existir uma expansão externa do capital, mas restrita ao período de formação do modo de produção. Com a revolução microeletrônica da década de 1980, no entanto, “já não pode ser gerado mais nenhum "novo modelo de acumulação"” (ibid.: s/p). Doravante, a "colonização" - talvez outro modo de falar de espoliação ou de expulsão ${ }^{145}$-, que só poderia ser um aspecto fenomênico, é tratada nos termos da contradição em processo e de seus limites (ibid.: s/p).

$\mathrm{O}$ argumento que vem à mente é aquele abordado por Marx na seção da Lei da queda tendencial da taxa de lucro (Marx, 1. III t. I, 1988, seção III), onde vemos como o aumento da

\footnotetext{
144 "O próprio capital é a contradição em processo, [pelo fato] de que procura reduzir o tempo de trabalho a um mínimo, ao mesmo tempo que, por outro lado, põe o tempo de trabalho como única fonte de riqueza" (Marx, 2011: 588-9, acréscimo da ed. alemã).

${ }^{145}$ Objetamos que o que é chamado de "colonização" por Scholz e seus interlocutores pode ser relacionado às teorias que enxergam o desenvolvimento do capitalismo a partir de relações com espaços não capitalistas por exemplo, como explicitamente estabelecido por Sassen (2016: 18) -, ou mesmo da "produção capitalista de relações não capitalistas de produção" (Martins, 1979), que sugerem uma acumulação eterna de capital, quiçá desatenta ao contexto histórico do modo de produção. Sobre isso, Scholz diz que "as mudanças qualitativas recentes à escala mundial há muito deixaram de poder ser esclarecidas com uma teoria da colonização, no fundo partindo das anteriores relações nas antigas colônias" (Scholz, 2016: s/p).
} 
composição orgânica do capital ${ }^{146}$ determina que igual ou crescente taxa de mais-valia gerada por uma força de trabalho individual exprime uma taxa decrescente de lucro. Cresce, ainda que não na mesma proporção, o volume de valor do capital constante. Uma mesma quantidade de força de trabalho, ou de capital variável, processa um volume sempre crescente de capital constante, barateando a produção, que passa a conter, entretanto, um quantum menor de trabalho para cada soma de capital. Visto de outra maneira, o aumento da produtividade do capital, com constantes revolucionamentos da base produtiva determinados pela concorrência (cf. id. 1. I t. II, 1986), corresponde a uma exploração cada vez menor de trabalho. Em última instância, é um processo que se realiza dispensando trabalho ${ }^{147}$.

No ensaio A ascensão do dinheiro aos céus, Kurz ([1995] 2002) enxerga na revolução microeletrônica a imposição dum "limite absoluto" do capital. Sua apreciação do problema se dá, antes de tudo, pelo descolamento do dinheiro de sua substância, o trabalho; em outras palavras, pela falta de coincidência do dispêndio abstrato de trabalho com sua forma representada no dinheiro (ibid.: s/p). Historicamente, ele avalia que a perda do padrão-ouro como lastro da moeda (em 1971) significa a perda da característica do dinheiro como meio de conservação do valor: o dinheiro se dessubstancializa, engendrando uma inflação estrutural (ibid:: s/p). Com a acumulação fordista, corrente até o final da década de 1970, a substância real de valor e suas formas de mediação se expandem, mas em razão do aumento da maisvalia relativa, isto é, da redução dos custos de reprodução com a força de trabalho. Aqui pelo menos, o capitalismo teria como se estender, interna e externamente, em tendência contrária à crise. Esgotada tal capacidade com a revolução microeletrônica, mesmo setores que apresentam lucratividade não responderiam ao processo de criação substancial de valor no conjunto da sociedade. Consoante o autor, a reprodução capitalista já teria alcançado seu "limite absoluto, ainda que o seu colapso (no sentido substancial) não se tenha realizado no plano fenomênico formal" (ibid:: s/p). Não explicaria o colapso, também, a redução acentuada da taxa de lucro, que indicaria tão só "o modo como aparece o limite relativo da reprodução

\footnotetext{
${ }^{146}$ A título de uma explicação da lei geral da acumulação..., portanto extraída do livro primeiro d' O capital, o desenvolvimento da relação capital procede alterando a proporção entre suas componentes, isto é, entre sua composição orgânica (capital constante, meios de produção) e técnica (capital variável, força de trabalho) (Marx, I. I t. II, 1986: 187). Vejam pelo corpo do texto que a mudança na composição do capital ocorre em direção ao aumento do capital constante.

${ }^{147}$ Assim colocada, a teorização retoma e aprofunda a passagem supracitada dos Grundrisse. Sem embargo, como tendência, a Lei apresenta causas contrariantes, sempre dadas pela possibilidade do capital intensificar seu grau de exploração do trabalho ou se expandir, territorialmente ou para novos setores (Marx, I. III t. I, 1988, cap. XIV). A preocupação de Marx é explicar, por meio dessas contra tendências, porque a queda da taxa de lucro não era maior ou mais rápida em sua época.
} 
capitalista", em condição de ampliação possível do modo de produção. Nos termos discutidos, com a imposição dos limites da valorização a taxa de lucro "deixa de existir" (ibid.: s/p):

O limite absoluto não aparecerá sob a forma duma simples aceleração linear da "queda tendencial", de modo que o capitalismo seja abandonado com resignação pelo management, por falta de rentabilidade. Antes, atingido o limite absoluto, finda também a acumulação absoluta de "valor" em geral. Em termos substanciais: a taxa de lucros não "diminui", mas deixa totalmente de existir, com o desaparecimento de massas suplementares de valor. O conceito torna-se sem sentido. Ao mesmo tempo, o processo de acumulação continua ainda formalmente por um certo período (e assim são auferidos lucros em termos formais), mas já sem nenhum vínculo com a substância real do valor (em queda), guiado apenas pela agora incontrolada criação de "capital fictício" e de dinheiro sem substância, nas suas diversas formas fenomênicas.

É possível extrair de Kurz (2002) que o valor produzido socialmente, conquanto possa prosseguir em meio ao colapso, já não remunera o capital necessário para desenvolver as forças produtivas. A acumulação, pois, precisa ser norteada pela geração de "capital fictício", sem substância. Nesse quesito, declaramos ser no mínimo curioso que Sassen (2016) tenha se isentado de interpretar o que denomina de financeirização, reduzindo sua exposição ao plano fenomênico (ibid., esp. cap. 3). A "multiplicação dos lucros", embolsados das expulsões (ibid.: 18), negligencia a exploração do trabalho como fundamento da produção de mais-valia e de sua distribuição em juro/lucro, salário e renda, como são tratados no terceiro volume d' $O$ capital (cf. Marx, 1. III t. II, 1986, cap. XLVIII). Sem esquecer que a própria produção de valor, como estamos tratando, é crítica na medida em que se processa repelindo seu fundamento, e apenas aparece, no dizer de Marx, como "momento específico [...] na consciência costumeira dos agentes da produção" (id. 1. III t. I, 1988: 21).

Nesta obra do filósofo alemão, ainda, é discutida a divisão do lucro em juro e ganho empresarial, de maneira que, como já apontado, o capital monetário do prestamista, em uso pelo capitalista atuante, explora trabalho, mas também retorna àquele acrescido de juros. Para o proprietário de capital, fetichistamente dinheiro é fonte de mais dinheiro, sem passar pelo processo de valorização, como um capital que rende juros (ibid., cap. XXIII).

Caso retornemos à consideração do dinheiro como meio de pagamento (id. 1 . I t. I, 1985, cap. III), com uma separação temporal entre venda e compra, podemos observar com o autor que "a mercadoria é vendida não contra dinheiro, mas contra uma promessa escrita de pagamento em determinado prazo" (id. 1. III t. I, 1988: 285). Tais adiantamentos compõem o 
pilar do crédito, que pode sequer explorar trabalho, autonomizando-se da produção de mercadorias, ou jamais ser quitado, num movimento de transferência de adiantamentos de títulos de crédito como fabricação de "capital fictício" (ibid., cap. XXV). Assim, inicialmente, o papel do crédito envolve a diminuição dos custos de circulação do capital, já que é empregado no processo de valorização. Só que o empréstimo também enseja a especulação com o rendimento do dinheiro, isto é, com a separação temporal entre mercadoria e dinheiro (ibid., cap. XXVII).

Aponta Kurz (2002: s/p), sobre o tema, que a promessa da coincidência entre trabalho e dinheiro vai sempre sendo adiada; com a inexequibilidade da valorização do capital, o crédito não recuperável é pago com novos créditos e assim se define como capital fíctício. $\mathrm{O}$ grande contraste identificado pelo autor é o limite absoluto dessa forma de reprodução do capital, enquanto na época de Marx o crédito ainda atua rompendo as barreiras imanentes à produção. O percurso histórico do crédito atravessa do custeio da produção de mais-valia para a dessubstancialização do valor. Em adendo, temos o aumento do custo do crédito demandado para as condições gerais e de infraestrutura do mercado, que, sendo mediado pelo Estado, indica a insuficiência das receitas deste (ibid:: s/p). Significa que a instituição necessita recorrer ao crédito para funcionar e manter as condições de produção, tendo papel central devido à sua impossibilidade de falir. No caso de crise, "o Estado não abrirá falência, mas simplesmente expropriará seus cidadãos-credores" (ibid.: s/p).

Segundo Harvey (2014: 97), são Estado e instituições financeiras quem criam capital fictício; para ele, “ativos em títulos ou notas provisórias desprovidos de suporte material mas que podem ser usados como dinheiro". É encargo do Estado gerir a desvalorização de ativos como meio de "permitir que a acumulação por espoliação ocorra sem desencadear um colapso geral" (ibid.: 126). Porém, aqui, a financeirização parece, digamos, mais suportar a espoliação enquanto dispositivo de acumulação ad aeternum do capital do que deflagrar a crise de dessubstancialização na qual se inclui o Estado (Kurz, 2002). Em Kurz, o neoliberalismo designaria a desregulamentação do mercado financeiro, não um novo estágio de acumulação.

A propósito, as funções do Estado moderno, assinaladas noutro ensaio deste autor (1995: 193-7), abrangem a juridificação das relações sociais, o encargo com os problemas sociais e ecológicos, a implantação e manutenção de agregados infraestruturais, a atuação como empresário direto e o protecionismo aliado a políticas de subsídio. Justamente pelos papéis que desempenha, o Estado revela a dependência de dinheiro para financiar suas medidas, primeiro com a tributação de seus cidadãos; depois, mostrando-se o esquema 
insuficiente, recorrendo ao crédito (ibid.: 198-9). De acordo com Kurz, trata-se dos limites da política e da capacidade do Estado regular o dinheiro, o que, entretanto, tenta ser compensado mediante novos planos econômicos (ibid.: 202). A capacidade de regulação da acumulação pelo Estado (aliás, sempre secundária em relação ao dinheiro) seria resumida ao fordismo, alcançando seu limiar com a revolução microeletrônica ${ }^{148}$ (ibid.: 206).

$\mathrm{Na}$ instituição do Estado brasileiro, podemos dizer que o recurso ao endividamento foi, precisamente, o que ensejou seu projeto de modernização recuperadora e negativa (Kurz, 1992: 192). Como demonstra Chico de Oliveira (2013), é basicamente contraindo dívidas externas que o Estado vai operar sua política de subsídios e de incentivos fiscais, aí inclusas as áreas de fronteira na Amazônia. Durante a ditadura civil-militar, tais políticas se traduzem no congelamento dos salários e na concentração de renda, com uma pauta de exportação a respaldar os subsídios e retroalimentar o recurso ao crédito externo. A crise orçamentária em vigor no desfecho do regime reverbera na retração dos incentivos, no aumento da carga tributária e numa tentativa de recrudescer a exploração dos trabalhadores, visando contrapor os gastos anteriores com a transferência dos ônus da crise para a população (ibid.: 94 e ss.).

Moldado o quadro de crise, os frutos da intervenção estatal na região e o esvaziamento dos órgãos de planejamento devem ultrapassar a avaliação de políticas. Por sinal, como avalia um artigo de Lencioni (1992: 89), com a crise de rentabilidade do capital industrial, a região vai perdendo sua base institucional, que não está sobrepujada historicamente; o que vai sendo consumido é a posição da região como questão de Estado. O discurso desenvolvimentista vai se modificando, transpondo da necessidade de industrialização para o progresso técnico e organizacional do capital. Mais exatamente:

Esse discurso que se assentou no apanágio da industrialização - como uma necessidade histórica da mobilidade do capital hegemônico -, se pauta, hoje em dia, num discurso fundado no progresso técnico e organizacional, como mecanismo ainda atual para a reprodução capitalista (ibid.: 83).

Dirigindo a atenção para a Calha Norte paraense, a disseminação do crédito, em particular via FNO, parece-nos constituir uma primeira aproximação da organização territorial recente centralizada no Estado. A segunda considera o discurso de sustentabilidade associado à demarcação de áreas protegidas e ao manejo florestal por empresas e pelas assim intituladas

\footnotetext{
${ }^{148}$ Nesse aspecto ele inclui a "teoria da regulação", da qual participam Aglietta e Orléan (1990). Para os teóricos franceses, o dinheiro é desprovido de qualquer substância, pois é signo da transferência do sacrifício do soberano, e assim tem sua existência restrita à sua trocabilidade, passível de regulação pela soberania estatal. A "teoria do valor" marxiana seria tributária da "filosofia especulativa" de Hegel, ausente, então, de qualquer constatação empírica.
} 
“comunidades tradicionais". Ambas as apreciações se ajustam à posição de Costa (2007) de pautar o crédito em critérios de eficiência produtiva que fortaleçam a competitividade interregional. Outro impasse que levantamos é o de uma nova noção de região, construída sobre o discurso de uma relação ecologicamente "sustentável" das comunidades agora "tradicionais", algo que confere aparência de imutabilidade à área: deixemos em aberto se há uma região que se reproduz sobre a simulação de sua autonomia como região de desenvolvimento sustentável.

Nessa configuração, manifestamente mudam as relações que caracterizam a fronteira e sua função. Uma mediação estatal cada vez mais dependente do capital fictício, caso parta para o escopo da espoliação, deixa de encarar a situação-limite atingida pela contradição em processo (Marx, 2011) da totalidade capitalista. Decerto, consoante ao diagnóstico de Kurz,

quanto mais fraca se tornar a acumulação real, tanto menos o crédito estatal será financiável, e quanto menos o Estado puder ser financiado, tanto maiores se tomarão as suas tarefas em virtude da crise estrutural da acumulação (Kurz, 1995: 205-6).

O abatimento da acumulação posto pela crise, ainda que represente uma progressiva incapacidade de financiamento das medidas estatais, inversamente demanda uma necessidade crescente de lidar com as vicissitudes do processo. Em conta da territorialização da fronteira na área investigada, postulamos que compõe uma medida do Estado o controle da população cada vez menos como força de trabalho eventualmente explorável, e mais como dependente de políticas assistencialistas. Dito de outro modo, se antes na fronteira observamos o esforço de formação do mercado nacional de terra e de trabalho, agora, nesta, a interposição do capital fictício tem de se fazer progressivamente mais presente. Mas não via financiamento de commodities agrícolas, que respalda procedimentos de expropriação como os observados no sudoeste paraense (cap. 4.3.2). Com a ordenação do corredor de conservação, o processo pode se dar mais pela redistribuição de fundos de reserva ambiental e por programas que parecem manter a autonomia do lavrador confinado na terra. A licitação de unidades de manejo é a primeira forma de lidar com o problema, e pode se expandir para outras estratégias previstas para a Flota do Paru, no caso duma série de promessas de desenvolvimento ${ }^{149}$. Nesta fronteira,

\footnotetext{
${ }^{149}$ Ampliação do manejo florestal madeireiro e não madeireiro (principalmente de castanha-do-pará, açaí, cacau e camu-camu - fruto com alto teor de vitamina C), ecoturismo e serviços ambientais são listados como atividades potenciais para a Flota (Pará, 2010: 22; 151-5), além do armazenamento de estoques de carbono (ibid.: 20). Existem consequências deletérias para populações locais decorrente da formação de áreas protegidas, tal qual assinalado por A. Kelly (2011) com parques ecoturísticos na África Central. Estes são controlados por multinacionais que exploram comunidades proletarizadas com salários bastante tacanhos, como uma indústria que se move a partir de direitos de imagem veiculados a paisagens. Fora isso, podemos
} 
se o trabalho instigado tende a não retomar ciclos de acumulação, restando a administração da dependência reificada do lavrador expropriado, este continua precisando mobilizar sua força de trabalho para sobreviver.

retomar os mecanismos de dilapidação oriundos de patentes de estoques genéticos em favor de grandes grupos farmacêuticos, também criticados pela autora, ou a conivência de ONGs que recebem donativos de empresas que, ao assim procederem, podem prosseguir poluindo onde mantém suas fábricas. Por último, temos que a operação do mercado de carbono por créditos negociados na bolsa de valores, ainda não regulado no Brasil, aponta tanto para a conservação como transformação de florestas em possíveis "desertos verdes" quanto para o aprofundamento da reprodução crítica - ou mais, colapsada (Kurz, 2002) - do capital. 


\section{CONSIDERAÇÕES FINAIS}

Chegando ao presente ponto , o leitor tem um panorama de como nossa investigação é exibida na forma de um percurso histórico, embora não linear, de mudanças nas relações de produção na fronteira. Se o último capítulo se debruça sobre o presente, é porque o consideramos como resultado de um processo. Com abordagens distintas sobre um mesmo tema, buscamos problematizar a constituição das relações assinaladas no trabalho sem contudo esgotá-las. Na formação de mercados autonomizados de terra, trabalho e capital na área, bem como na regulação da aparente independência do lavrador, também se institucionaliza o Estado, parte da imposição da mercadoria como forma da mediação social. $\mathrm{O}$ processo, como muito falado, passa às costas dos sujeitos e estipula as perspectivas e práticas examinadas. Portanto, não seria estranho argumentar que, do ângulo da fronteira, distinguimos uma falta de autonomia do Estado em relação ao desenvolvimento da forma mercadoria.

Pensando na assertiva acima é que partimos do conflito entre formas particulares das relações de produção e a constituição contraditória de um Estado de origem colonial que depende gradualmente de dinheiro para financiar suas medidas. A internalização dessa necessidade se traduz em um projeto nacional de modernização, remetido no capítulo de abertura aos planos iniciais de colonização do que hoje é a Calha Norte paraense. As dinâmicas regionais (Oliveira, 2008), ao parecerem destacadas da totalidade, se apresentam como estorvo a ser suplantado por iniciativas de ocupação produtiva e regularização do uso do solo. Dessa feita, o intuito de gestar força de trabalho livre, a valorizar capital circulando no território nacional, é ditado socialmente e se efetiva por meio do Estado, apesar de naquela altura já apontarmos para o óbice da difusão do equivalente geral, seja como subsídio ao planejamento seja intermediando a reprodução das personas regionais.

Mais especificamente, buscamos inscrever a necessidade progressiva de dinheiro, na territorialização de relações capitalistas de produção, destrinchando um percurso que vai da fronteira como expediente da reprodução regional àquela planejada pelo Estado. A fronteira, primeiramente, viabiliza a posse de meios de produção não produzidos, à medida que a terra não é monopólio de uma classe de proprietários. Mas entrementes passa, sem excluir a função precedente, a integrar os mercados nacionais, em formação, de terra, trabalho e capital, servindo de locus da superpopulação relativa. Em miúdos, este último movimento é o que se expressa nos capítulos 2 e 3, quando confrontamos as relações de produção centralizadas no 
monopólio da circulação, por parte de um armazém, com o esforço de documentação da terra pelo Incra. As relações vão sendo caracterizadas pelo mercado e por relativa concentração fundiária, motivando a expansão do apossamento pela mobilização da força de trabalho dos lavradores.

Da perspectiva do trabalho, o processo de exploração atravessa da submissão na esfera da circulação, com extração do excedente pela classe dominante regional, para a venda de força de trabalho por uma sujeição impessoal à forma mercadoria. Transcorre com o aprofundamento da necessidade de mobilização, porém, gradual incapacidade de incorporação da população de fronteira no processo produtivo. É por isso que, no capítulo de encerramento da dissertação, notamos a reprodução dos lavradores cada vez mais interposta por fomentos estatais que fixam na terra essa população. A formação da aparência de autonomia de terra, trabalho e capital suscita a mobilização do trabalho ainda que guardada a simulação de continuidade na condição de lavrador independente. O que queremos destacar dessa confusão é que existem processos de expropriação que não expulsam, não divorciam o lavrador de sua base fundiária - trata-se de uma referência à autonomização, não de um dogma.

Mas claro que, simultaneamente, o capital não deixa de mobilizar. Por intermédio do Estado, longe de ter no horizonte a gestão da população como força de trabalho que acumula capital, ele mobiliza, digamos, ficticiamente, através do crédito e de políticas assistencialistas. Aqui, a simulação de continuidade, ou seja, de não-autonomização das categorias do capital, é uma espetacularização do cotidiano dos lavradores. Quer dizer: sobrepujando a conhecida acepção de sociedade do espetáculo de Debord (1997), as relações que repõem a região são autonomizadas numa representação destas mesmas relações, correspondente à situação da ficcionalização que simula a valorização do capital.

À simulação da autonomia do lavrador acompanha a limitação de reservas ecológicas. Encaramos a conservação como outra forma de operar com a terra como mercadoria e de financiar o próprio Estado quando o limite absoluto da acumulação já foi atingido. Daí o manejo florestal convir no recolhimento de fundos ambientais e servir à promessa de realização do mercado turístico e de estoques de carbono, em nosso caso. Nessa configuração, a gestão do trabalho e da terra, legitimada no discurso da "sustentabilidade", atesta um inchaço das tarefas do Estado. Ao mesmo tempo, a capacidade do Estado se autofinanciar e cobrir encargos com o mercado para garantir as condições de produção vai colapsando.

Foi relevante mostrar como a crise oferece uma entrada para a retomada da relação entre Estado e dinheiro consubstanciada na forma social, o que permite desdizer a ideia de regulação política. No campo das políticas territoriais, o intento da regulação se deu, de 
começo, na redução da região a uma superfície de intervenção, que segmenta um espaço aprioristicamente concebido. Depois - sem anular absolutamente a perspectiva anterior -, a noção de região é aquela que simula uma relação ecológica do lavrador com a terra como "sustentável"; é algo que justifica tanto a sustentabilidade ambiental quanto a competitividade regional. A intervenção teria um feitio corretivo, voltado para o desenvolvimento e ajustado aos parâmetros do que é tido por "sistemas de produção tradicionais", a despeito de pretenso “empobrecimento técnico" dos produtores (Oliveira, 2002: 132-3).

Nas obras analisadas na dissertação, indicamos, tanto na naturalização da reprodução capitalista como no anseio por modernizar, uma preocupação quanto ao risco da interdição da produção agrícola e à expulsão ou estagnação produtiva. São diagnósticos retificados com a simplificação do acesso ao dinheiro como premissa da reposição da autonomia do lavrador, mas a autonomia de concorrer no mercado e manejar comunitariamente recursos. Tais pesquisas, no limite, se encerram nos problemas concretos da reprodução pessoal, e por isso, a contragosto ou não, negligenciam como avança a dependência reificada de capital.

Caso a questão seja a viabilidade de prosseguir com a territorialização da fronteira, terminamos por sugerir algum esvaziamento de sentido da expropriação que expulsa da terra e compele força de trabalho para o avanço da fronteira. Inequivocamente, expulsões e ocupação fundiária pela posse e pela grilagem continuam a acontecer, mas direcionamos nossa análise à relação do fenômeno com a totalidade. Esse expediente, se necessário à formação categorial do capital, esbarra no limite interno da valorização, relativo ao próprio esgotamento do Estado e da forma social. Assim considerando, o caminho percorrido é o da fronteira como momento da imposição do trabalho (a substância social) à dessubstancialização da produção como crise do trabalho. Podemos designar a violência desse processo de formação e desfibrilação na disputa pela fronteira não só na retirada à força de lavradores. Existe uma expropriação que, nos termos discutidos no trabalho, não expulsa, mas confina e reitera a representação da nãoautonomização das categorias do capital na gestão de emergência de força de trabalho no território. Tal forma da administração, ao sustentar um trabalho incapaz de remunerar os juros que financiam o Estado e a reprodução capitalista, não estranhamente requenta a promessa de um novo ciclo de acumulação. É a espera pelo retorno de Godot, de Beckett, que tem ocorrido como uma inegável barbárie. 


\section{REFERÊNCIAS}

\section{Caracterização das fontes primárias}

Caderno de campo I. Pesquisa na Biblioteca da Sudam e na Biblioteca Central da Universidade Federal do Pará. Belém, maio de 2017.

Caderno de campo II. Anotações de trabalho de campo. Santarém e Monte Alegre, maio e junho de 2017.

Caderno de campo III. Anotações de trabalho de campo. Monte Alegre, outubro a dezembro de 2017.

\section{Entrevistas citadas na pesquisa}

Avelino. Entrevista gravada no Limão. Monte Alegre/PA, 08 de novembro de 2017.

Bia. Entrevista gravada no Limão. Monte Alegre/PA, 09 de novembro de 2017.

Ceará. Entrevista não gravada no Limão. Monte Alegre/PA, 16 de novembro de 2017.

Celi. Entrevista gravada no Limão. Monte Alegre/PA, 08 de novembro de 2017.

Chico Bahia. Entrevista gravada no Limão. Monte Alegre/PA, 10 de novembro de 2017.

Dó. Entrevista gravada em Linha do Ererê. Monte Alegre/PA, 30 de maio de 2017.

Dubá e Mazinha. Entrevista gravada no Limão. Monte Alegre/PA, 02 de junho de 2017.

Imá. Entrevista gravada no Limão. Monte Alegre/PA, 02 de junho de 2017.

Jairo. Entrevista gravada na Canp. Monte Alegre/PA, 30 de outubro de 2017.

João André. Entrevista gravada no Limão. Monte Alegre/PA, 08 de novembro de 2017.

Kazuo. Entrevistas gravadas no quilombo do Piafu e na cidade. Monte Alegre/PA, 26 de novembro de 2017.

Lúcio e Reinaldo. Entrevista gravada no PDS Serra Azul. Monte Alegre/PA, 28 de novembro de 2017.

Miguel. Entrevista gravada em Linha do Ererê. Monte Alegre/PA, 26 de maio de 2017.

Moradora. Entrevista não gravada em Linha do Ererê. Monte Alegre/PA, 01 de novembro de 2017.

Nobó. Entrevista gravada no PDS Serra Azul. Monte Alegre/PA, 22 de novembro de 2017.

Paulinho. Entrevistas gravadas no PDS Serra Azul. Monte Alegre/PA, 17 e 29 de novembro de 2017.

Paulino. Entrevista gravada em Dois Galhos. Monte Alegre/PA, 30 de novembro de 2017.

\section{Livros, artigos, teses e dissertações}

AGLIETTA, Michel; ORLÉAN, André. A violência da moeda. São Paulo: Brasiliense, 1990.

ALMEIDA, Cícero N. Mosaicos de Monte Alegre. Rio de Janeiro: Editora do autor, 1979. 
ARAÚJO, Roberto. "Fondation d'un lieu et rapports de domination". In: LUSOTOPIE. L'oppression paternaliste au Brésil. Paris: Karthala, 1996.

BAUMFELD, Carlos M. "Formação do trabalho: mobilidade e imobilização da força de trabalho na agricultura brasileira. 'Uma análise crítica da formulação de Gaudemar'”. Anuário do instituto de geociências. Rio de Janeiro: UFRJ, 1984.

BECKER, Bertha K. Geopolítica da Amazônia. Rio de Janeiro: Jorge Zahar, 1982.

BOECHAT, Cássio A. O colono que virou suco: terra, trabalho, Estado e capital na modernização da citricultura paulista. Doutorado em Geografia Humana. São Paulo: DGFFLCH-USP, 2013.

BRITO, Brenda; BARRETO, Paulo. Primeiro ano do Programa Terra Legal: Avaliação e Recomendações. Belém: Imazon, 2010.

CARVALHO, Luciana G. de "Relações de trabalho nos balatais". Horizontes Antropológicos. Porto Alegre, ano 19, n. 39, jan./jun. 2013.

COSTA, Francisco de A. "Políticas públicas e dinâmica agrária na Amazônia: dos incentivos fiscais ao FNO". In: TURA, Letícia R.; (org.). Campesinato e Estado na Amazônia: impactos do FNO no Pará. Brasília: Brasília jurídica/FASE, 2000.

. "A questão agrária na Amazônia e os desafios estratégicos de um novo desenvolvimento". In: COSTA, Wanderley M.; BECKER, Bertha K.; ALVES, Diógenes (org.). Dimensões humanas da Biosfera-atmosfera na Amazônia. São Paulo: Edusp, 2007.

CRUZ, Ernesto. Colonização do Pará. Belém: CNPq/INPA, 1958.

DEBORD, Guy. A sociedade do espetáculo. Rio de Janeiro: Contraponto, 1997.

EMMI, Marília F. Um século de imigrações internacionais na Amazônia brasileira (18501950). Belém: Naea, 2013.

FURTADO, Celso. Formação econômica do Brasil. São Paulo: Companhia Editora Nacional, 1984.

GAUDEMAR, Jean-Paul de. Mobilidade do trabalho e acumulação do capital. Lisboa: Estampa, 1977.

GARRIDO FILHA, Irene. O Projeto Jari e os capitais estrangeiros na Amazônia. Petrópolis: Vozes, 1980.

GEFFRAY, Christian. "Le modèle de exploitation paternaliste". In: LUSOTOPIE. L'oppression paternaliste au Brésil. Paris: Karthala, 1996.

. A opressão paternalista: cordialidade e brutalidade no cotidiano brasileiro. Rio de Janeiro: Educam, 2007.

GENTIL, Janete Marília. A juta na agricultura de várzea de Santarém, Médio Amazonas. Mestrado em Geografia. Recife: DG-UFPE, 1983.

GRAZIANO DA SILVA, José. Modernização dolorosa: estrutura agrária, fronteira agrícola e trabalhadores rurais do Brasil. Rio de Janeiro: Jorge Zahar Editores, 1982. 
HARTSHORNE, Richard. Propósitos e natureza da geografia. São Paulo: Hucitec, 1978.

HARVEY, David. Condição pós-moderna: uma pesquisa sobre as origens da mudança cultural. São Paulo: Edições Loyola, 2012.

. O novo imperialismo. São Paulo: Edições Loyola, 2014.

HÉBETTE, Jean; MARIN, Rosa Elizabeth A. Colonização para quem? Belém: NAEA, 1979. . "Mobilidade do trabalho e fronteira amazônica: a Belém-Brasília". Anais do II Encontro Nacional de Estudos Populacionais. Águas de São Pedro, 1981.

HEGEL, George W. F. Enciclopédia das ciências filosóficas em compêndio. Livro I: Ciência da lógica. São Paulo: Edições Loyola, 2013.

HEIDEMANN, Heinz Dieter; TOLEDO, Carlos de A.; BOECHAT, Cássio A. "O trabalho no Brasil: traçado de sua interpretação”. Estudos avançados. São Paulo, 83 (1), 2014.

IANNI, Octávio. Colonização e contra-reforma agrária na Amazônia. Petrópolis: Vozes, 1979.

INCRA. Programa operacional para o ano de 1975 para o Projeto Integrado de Colonização Monte Alegre . Belém: Incra, 1975.

ISHIZU, Tatsuo. Imigração e ocupação na fronteira do Tapajós: os japoneses em Monte Alegre - 1926-1962. Mestrado em História. Belém: CFCH-UFPA, 2005.

KELLY, Alice. "Conservation practice as primitive accumulation". Journal of peasant studies, 38: 4, 2011.

KURZ, Robert. $O$ colapso da modernização: da derrocada do socialismo de caserna à crise da economia mundial. Rio de Janeiro: Paz e Terra, 1992.

"A falta de autonomia do Estado e os limites da política: quatro teses sobre a crise da regulação política'. Revista Indicadores Econômicos FEE. Porto Alegre, v. 23 n. 1, 1995.

. “A ascensão do dinheiro aos céus". Krisis n. 26, janeiro de 1995. Tradução de Lumir Nahodil em 2002. Disponível em: <obeco.planetaclix.pt/rkurz115.htm>. Acesso em: 22 de dezembro de 2015.

Hedra, 2010.

"Dominação sem sujeito". In: Razão sangrenta. São Paulo:

Dinheiro sem valor: linhas gerais para uma transformação da crítica da economia política. Lisboa: Antígona, 2014.

LEAL, Victor N. Coronelismo, enxada e voto: as eleições e o regime representativo no Brasil. São Paulo: Alpha-Ômega, 1975.

LEITE, Ana Carolina G. O campesinato no Vale do Jequitinhonha: da sua formação no processo de imposição do trabalho à crise da (sua) reprodução capitalista. Doutorado em Geografia Humana. São Paulo: DG-FFLCH-USP, 2015. 
LENCIONI, Sandra. "O discurso desenvolvimentista face à crise da economia. A falência das políticas de desenvolvimento regional”. Revista do departamento de geografia, 6, 1992.

"Acumulação primitiva: um processo atuante na sociedade contemporânea". Confins, 14|2012. Disponível em: <journals.openedition.org/confins/7424>. Acesso em: 28 de dezembro de 2016.

Região e geografia. São Paulo: Edusp, 2014.

LIMA, Rui C. Pequena história territorial do Brasil: sesmarias e terras devolutas. Goiânia: EdUFG, 2002.

LOPES, Paloma M. D. O pluralismo médico Wayana-Aparai: uma experiência intercultural. Mestrado em Antropologia Social. São Paulo: DA-FFLCH-USP, 1994.

MARIA, Estanislau. "Assentados vendem lotes no PA; INCRA se diz incapaz de fiscalizar". Folha de São Paulo. São Paulo, domingo, 31 de dezembro de 1995. Disponível em: <www1.f olha.uol.com.br/fsp/1995/12/31/brasil/19.html>. Acesso em: 23 de setembro de 2016.

MARIN, Rosa Elizabeth A. e CASTRO, Edna Maria R. Negros do Trombetas: guardiães de matas e rios. Belém: Cejup, 1997.

MARTINS, José de S. Capitalismo e tradicionalismo. São Paulo: Livraria Pioneira, 1975. . O cativeiro da terra. São Paulo: Lech, 1979.

Contexto, 2014.

Fronteira: a degradação do outro nos confins do humano. São Paulo:

MARX, Karl. El capital libro I capítulo VI (inédito). Cidade do México: Siglo XXI, 1974.

- O capital: crítica da economia política. Livro I: $O$ processo de produção do capital, tomo I. São Paulo: Nova cultural, 1985.

O capital: crítica da economia política. Livro I: O processo de produção do capital, tomo II. São Paulo: Nova cultural, 1986.

O capital: crítica da economia política. Livro III: O processo de produção global do capital, tomo I. São Paulo: Nova cultural, 1988.

O capital: crítica da economia política. Livro III: O processo de produção global do capital, tomo II. São Paulo: Nova cultural, 1986.

- Grundrisse: esboços para a crítica da economia política. São Paulo/Rio de Janeiro: Boitempo/EdUFRJ, 2011.

MENEZES, Thereza Cristina C. "A regularização fundiária e as novas formas de expropriação rural na Amazônia”. Estud. Soc. e Agric. Rio de Janeiro, vol. 23, n. 1, 2015.

MONBEIG, Pierre. Pioneiros e fazendeiros de São Paulo. São Paulo: Polis/Hucitec, 1984.

MUNIZ, João de Palma. Immigração e colonisação (1616-1916). Belém: Imprensa oficial do estado, 1916.

Castanhaes de Alemquer. Belém: Imprensa oficial do estado, 1922. 
MUSUMECI, Leonarda. O mito da terra liberta. São Paulo: Anpocs/Vértice, 1988.

NOVAIS, Fernando A. Portugal e Brasil na crise do antigo sistema colonial (1777-1808). São Paulo: Hucitec, 1983.

OLIVEIRA, Ariovaldo U. Integrar para entregar. Campinas: Papirus, 1988. . Amazônia: Monopólio, expropriação e conflitos. Campinas: Papirus, 1990. . A agricultura camponesa no Brasil. São Paulo: Contexto, 1991.

. "BR-163 Cuiabá-Santarém: corrupção, violência e grilagem”. TORRES, Maurício (org.). Amazônia revelada: BR-163 em questão. Brasília: CNPq, 2005.

Labur edições, 2007. Modo capitalista de produção, agricultura e reforma agrária. São Paulo:

OLIVEIRA, Francisco de. A noiva da revolução/Elegia para uma re(li)gião. São Paulo: Boitempo, 2008. . Crítica à razão dualista/O ornitorrinco. São Paulo: Boitempo, 2013.

OLIVEIRA, Myriam Cyntia Cesar de. Evolução do sistema agrário da margem esquerda do Baixo Amazonas. Mestrado em Agriculturas Familiares e Desenvolvimento Sustentável. Belém: NEAF-UFPA, 2002.

PITTA, Fábio T. As transformações na reprodução fictícia do capital na agroindústria canavieira paulista: do Proálcool à crise de 2008. Doutorado em Geografia Humana. São Paulo: DG-FFLCH-USP, 2016.

PRADO Jr., Caio. A questão agrária no Brasil. São Paulo: Brasiliense, 1979. Formação do Brasil contemporâneo: Colônia. São Paulo: Publifolha, 2000.

REIS, Arthur Cezar F. Monte Alegre: sua história. Monte Alegre: Ed. da prefeitura, 1949.

RRX. Resumo público Plano de Manejo Florestal Sustentável - Floresta Estadual do Paru UMF' s III - VII - IX. Monte Alegre: RRX Mineração e Serviços Ltda., 2017.

SANTOS, Roberto. História econômica da Amazônia (1800-1920). São Paulo: T. A. Queiroz, 1980.

SASSEN, Saskia. Expulsões: brutalidade e complexidade na economia global. Rio de Janeiro: Paz e terra, 2016.

SCHOLZ, Roswitha. "Cristóvão Colombo forever? Para a crítica das actuais teorias da colonização no contexto do "Colapso da Modernização"”. EXIT!, n. 13, 2016. Tradução de Boaventura Antunes em 2016. Disponível em: <www.obeco-online.org/roswitha_scholz24.ht m>. Acesso em: 10 de novembro de 2017.

SCHOR, Tatiana. Ciência e tecnologia: o caso do Experimento de Grande Escala da BiosferaAtmosfera na Amazônia. São Paulo: Fapesp/Annablume, 2008.

SCHWARCZ, Lília M. O espetáculo das raças: cientistas, instituições e questão racial no Brasil 1870-1930. São Paulo: Companhia das Letras, 2005. 
SORRE, Max. "Migrações e mobilidade do ecúmeno". In: MEGALE, Januário F. (org.). Max. Sorre. São Paulo: Ática, 1984.

TOLEDO, Carlos de A. A região das lavras baianas. Doutorado em Geografia Humana. São Paulo: DG-FFLCH-USP, 2008.

; BOECHAT, Cássio A. "Mobilização do trabalho e estudo da região". Boletim campineiro de geografia. Campinas, v.2 n. 3, 2012.

TORRES, Maurício G. "Fronteira: um eco sem fim. Considerações sobre a ausência do Estado e exclusão social nos municípios paraenses do eixo da BR-163". (org.). Amazônia revelada: Caminhos da BR-163 em questão. Brasília: CNPq, 2005.

TURA, Letícia R. "Notas introdutórias sobre os Fundos Constitucionais de Financiamento e sua configuração na Região Norte". In: .; COSTA, Francisco de A. (org.). Campesinato e Estado na Amazônia: impactos do FNO no Pará. Brasília: Brasília jurídica/FASE, 2000.

UENO, Koji. História de minha vida: um colono em Monte Alegre. Monte Alegre: editora do autor, 2005.

VECINA, Cecília C. As comunidades "quilombolas" em Eldorado (Vale do Ribeira/SP) e a mobilização do trabalho imposta pelo PRONAF: a relação entre a expropriação e a autonomização das categorias sociais capitalistas. Mestrado em Geografia Humana. São Paulo: DG-FFLCH-USP, 2018.

VELHO, Octávio. Capitalismo autoritário e campesinato. Rio de Janeiro: Jorge Zahar, 1979. Frentes de expansão e estrutura agrária. Rio de Janeiro: Jorge Zahar, 1981.

WAIBEL, Leo. "As zonas pioneiras do Brasil". Revista brasileira de geografia. Rio de Janeiro: IBGE, ano XVII, n. 4, out-dez. de 1955.

WALLACE, Alfred R. Viagem pelos rios Negro e Amazonas. São Paulo/Belo Horizonte: Edusp/Itatiaia, 1979.

WEINSTEIN, Barbara. A borracha na Amazônia: expansão e decadência (1850-1920). São Paulo: Hucitec, 1993. 